\title{
norden
}

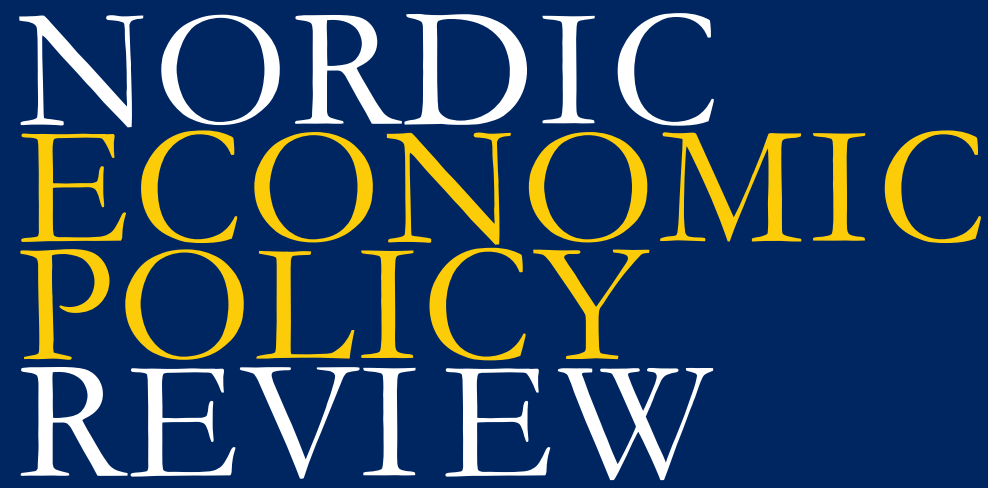

FISCAL CONSEQUENCES

OF THE CRISIS

Introduction Torben M. Andersen and Steinar Holden

Some lessons for fiscal policy from the financial crisis

Philip Lane, Trinity College Dublin and CEPR

Fiscal policy and macroeconomic stability:

New evidence and policy implications.

Xavier Debrun, IMF, and Radhicka Kapoor, London School of Economics

Fiscal sustainability in the wake of the financial crisis

Torben M. Andersen. University of Arhus and CEPR

Fiscal policy and the labor market at times of debt

Giuseppe Bertola, University of Torino and CEPR

Fiscal costs of financial support

Daehaeng Kim and Manmohan Singh Kumar, IMF.

Monetary implications of the crisis: ominance at stake

Charles Wyplozs, Graduate Institute in Geneva and CEPR

The Swedish fiscal policy framework

Robert Boije, Albin Kainelainen and Jonas Norlin,

Swedish Ministry of Finance 


The Nordic Economic Policy Review is published by the Nordic Council of Min isters and addresses policy issues in a w ay that is useful for informed non-specialists as well as for professional economists. All articles are commissioned from leading professional economists and are s ubject to peer review prior to publication.

The Nordic Economic Policy Review is published twice a year. The journal is distributed free of charge to members of the Nordic economic associations. The easiest way of subscribing to the NEPR is theref ore to become a member of one of these associations, i.e.,

Denmark: Nationaløkonomisk Forening

Finland: Taloustieteellinen Yhdistys

Norway: Samfunnsøkonomene

Sweden: Nationalekonomiska Föreningen

For institutional subscriptions, please contact nepr@iies.su.se. 


\section{Nordic Economic Policy Review}

Number 1 / 2010

Fiscal Consequences of the Crisis 
Nordic Economic Policy Review Number 1 / 2010

Fiscal Consequences of the Crisis

TemaNord 2010:558

(C) Nordic Council of Ministers, Copenhagen 2010

ISBN 978-92-893-2089-4

Print: Arco Grafisk A/S, Skive

Cover: Jette Koefoed/Pub.Unit/NCM

Layout: Klaus Munch Haagensen/Pub.Unit/NCM

Copies: 5000

Printed on environmentally friendly paper

This publication can be ordered on www.norden.org/order. Other Nordic publications are available at www.norden.org/publications

Printed in Denmark

Nordic Council of Ministers

Ved Stranden 18

DK-1061 København K

Phone (+45) 33960200

Fax (+45) 33960202

\author{
Nordic Council \\ Ved Stranden 18 \\ DK-1061 København K \\ Phone (+45) 33960400 \\ Fax (+45) 33111870
}

www.norden.org

\section{Nordic co-operation}

Nordic cooperation is one of the world's most extensive forms of regional collaboration, involving Denmark, Finland, Iceland, Norway, Sweden, and three autonomous areas: the Faroe Islands, Greenland, and Åland.

Nordic cooperation has firm traditions in politics, the economy, and culture. It plays an important role in European and international collaboration, and aims at creating a strong Nordic community in a strong Europe.

Nordic cooperation seeks to safeguard Nordic and regional interests and principles in the global community. Common Nordic values help the region solidify its position as one of the world's most innovative and competitive. 


\section{Contents}

Introduction: Fiscal consequences of the crisis

Torben M. Andersen and Steinar Holden

Some lessons for fiscal policy from the financial crisis

Philip R. Lane

Fiscal policy and macroeconomic stability: New evidence and policy implications

Xavier Debrun and Radhicka Kapoor 35

Fiscal sustainability in the wake of the financial crisis

Torben M. Andersen

Fiscal policy and labor markets at times of public debt

Giuseppe Bertola.

Fiscal costs of financial sector support: Measures and implications

for fiscal policy

Daehaeng Kim and Manmohan S. Kumar

Monetary implications of the crisis: Dominance at stake

Charles Wyplosz.

The Swedish fiscal policy framework

Robert Boije, Albin Kainelainen and Jonas Norlin 199 



\section{Introduction: Fiscal consequences of the crisis}

\section{Torben M. Andersen and Steinar Holden}

In the immediate aftermath of the financial crisis, there were strong calls for a more active fiscal stabilization policy. Although monetary policy turned very expansionary, via conventional and less conventional instruments, this was not sufficient to prevent sharp reductions in output and employment. The automatic fiscal stabilizers were at work, but this was also seen as insufficient to stabilize the economy. Accordingly, many countries undertook discretionary fiscal policy changes to dampen the consequences of the crisis for output and employment.

However, the financial crisis has turned into a fiscal policy crisis. The crisis immediately led to large budget deficits as could be expected, given automatic budget reactions and discretionary policy initiatives. In many cases these deficits came on top of already high debt levels, reflecting failures to consolidate public finances in the favorable years prior to the financial crisis. To make the situation even worse, most countries also have projected future financial problems due to changing demographics and a failure to undertake reforms to guard fiscal sustainability. While there is large variation across countries in terms of the initial situation - the effects of the crisis, and the projected path for public finances - there is no doubt that a large number of countries face a public finance problem.

For some countries the combination of a large budget deficit, a large public debt and uncertain prospects has caused a reaction in financial markets, involving a sharp increase in interest rates and default risks of public debt. For these countries it has become imperative to tighten fiscal policy considerably in order to achieve credibility in financial markets. However, even for 
other countries with smaller and less acute problems, substantial reforms are required. In short, the fiscal policy agenda has shifted from the question of how to stabilize the economy to a need for consolidating public finances. This, of course, also points to more structural problems underlying fiscal policy design.

Prior to the crisis, there was a strong consensus that stabilization policy should mainly be left to monetary policy, leaving fiscal responses to be confined to the automatic stabilizers. As a consequence, economic research mainly addressed problems in monetary policy, while fiscal policy was more or less neglected. The financial crisis has thus revealed a weakness in the discipline in the sense that there is scant recent research which policy makers can turn to when planning fiscal policy. It is an interesting question why research became so non-diversified and focused on fine-tuning the understanding of monetary policy at the cost of a neglect of fiscal policy. The purpose of this volume of the Nordic Economic Policy Review is to present some recent work on fiscal policy which explicitly takes outset in the experience from the financial crisis. The set of papers in the volume offers a broad perspective on the fiscal implications of the financial crisis, both to draw lessons but also to guide future policy making.

In Some lessons for fiscal policy from the financial crisis, Phillip Lane discusses how fiscal policy can be used to stabilize the economy. It is argued that the room for short-run stabilization policy depends on the underlying public finance situation in terms of the structural balance and debt position. The degrees of freedom in stabilization policy are created in good and normal times by pursuing a prudent fiscal policy. However, sectoral and external imbalances may hide weaknesses in the overall situation, implying that the fiscal policy should not only relate to the output cycle, but should also respond to such imbalances. To avoid pro-cyclical biases and a neglect of structural and medium-run considerations, the institutional setting for fiscal policy decisions is crucial. It is argued that fiscal policy is more likely to contribute to stabilizing the economy if it is conducted within a formal fiscal framework that combines a set of fiscal rules with a substantive role for an independent fiscal policy council. This has to be complemented by an up-todate knowledge base on the effects of fiscal policy. The current crisis has revealed the poor state of the profession's knowledge about the effectiveness of fiscal interventions. Successful stabilization therefore requires not only 
institutional reforms but also a better empirical understanding of how fiscal policy affects macroeconomic outcomes.

Debrun and Kapoor respond to this quest in Fiscal policy and macroeconomic stability: new evidence and policy implications by providing new empirical evidence on the role of automatic stabilizers and the effects of fiscal policy. The role of the stabilization power of fiscal policy has been contested by analyses indicating that fiscal policy has not been contributing to stabilization, and by evidence that automatic stabilizing effects have weakened. An important contribution of the paper is to take into account that government actions can both induce and absorb shocks. Discrete fiscal policy changes driven by other motives than stabilization may thus contribute to more macroeconomic volatility. However, this does not say anything about the stabilizing powers of fiscal policy, and it is therefore important to separate the different roles of fiscal policy. The paper finds support for the view that automatic stabilizers actually do stabilize the economy, and that they are the main source of fiscal stabilization. In addition, the view that policy changes not systematically related to the business cycle are destabilizing may not be as robust as suggested in the literature. Finally, the authors also present tentative evidence that automatic stabilizers were the main channel of fiscal stabilization during the great recession of 2009.

A key policy question is how and when to exit from a short-run focus on stabilization to a medium-run focus on consolidation, an issue addressed in Fiscal sustainability in the wake of the financial crisis by Torben M. Andersen. It has become standard to assess the medium- and long-run constraint on fiscal policy by presenting measures of fiscal sustainability. This is a clear improvement in fiscal policy planning. The direct effect of the crisis on fiscal sustainability is in most cases relatively small, but it may add to sustainability problems already present. The adverse effect will be larger to the extent that the crisis causes a persistent decrease in employment. The paper then turns to how policies should deal with the sustainability problems. Conventional sustainability analyses take as a given that changes should be smoothed across time and thus generation. However, whether this is appropriate depends critically on the cause of sustainability problems as well as intergenerational distribution issues. Moreover, the sustainability metric may conceal important information revealed by looking at the budget profile, which in many cases shows that meeting the technical requirement for fiscal sustainability does not necessarily imply that the budget profile is reliable 
and credible. Even if there is no acute debt crisis, the implication is that most countries face a serious problem in consolidating public finances in the very near future. Finally, the paper addresses the tension between stabilization of the economy in the short run and maintaining fiscal sustainability - a tension that is often taken for granted in policy discussions. It is argued that this depends critically on the nature of the problem and the chosen policy instruments. Policy reforms addressing sustainability problems via, e.g., retirement reforms, may reduce private savings, and therefore increase aggregate demand in the short run.

The public finance problems encountered in a number of countries underline the constraint that fiscal policy imposes on other forms of economic policy. Austerity packages implemented or planned for coping with consolidation needs include cutbacks on social and redistributive policies. In Fiscal policy and the labor market at times of debt, Giuseppe Bertola explores how the public debt situation (debt level and debt servicing) influences reform incentives and labor market performance. The main hypothesis is that, if the debt level is low, higher unemployment and lower employment may appear to be an acceptable price for desirable redistribution of risk and resources. However, the same policy choice may be out of reach when tax revenue has to be tasked to the purpose of servicing or reducing debt. The paper considers the empirical relationships between public finance indicators and labor market policies and outcomes for the period 1980-2000. It is found that high debt is associated negatively with employment and positively with unemployment. Policy responses include higher taxes, but also some retrenchment of unemployment insurance and active labor market policies. By considering the cases of Sweden and United Kingdom, more clear evidence is found of a retrenchment of redistributive policies as a response to large public finance problems. The paper thus underscores the point that prudent fiscal policies may be the best way to safeguard distributional and social objectives.

The financial crisis prompted an unprecedented policy response at the global level involving conventional and unconventional fiscal and monetary policies. In the borderline between fiscal and monetary policy, many countries provided significant support to their financial sectors to prevent an economic catastrophe and to stabilize market conditions. These initiatives are analyzed by Daehaeng Kim and Manmohan S. Kumar in Fiscal costs of financial support. The policy initiatives were crucial to the financial sector, but they may also have important implications for public finances and public 
intervention more generally. The interventions were unusually bold and speedy, even if the magnitude and nature varied markedly across countries, and generally were larger in some advanced countries. For the advanced G20 economies, the average amount utilized for capital injections and asset purchases was around 3.5 percent of GDP. This is much lower than the pledged amounts, reflecting the precautionary nature of initial pledges, the need to err on the side of caution, as well as effectiveness of the initial responses. In past crises in the advanced countries, the recovery rate has often been above 50 percent. It could be even higher in this case, reflecting the fact that support from the budget, such as capital injections and asset purchases, has been more limited than in past episodes, aided by extensive use of containment measures and large fiscal and monetary expansions. However, the broader measures of the costs of the crisis - referring to fiscal impact of induced recessions and real economic costs - were estimated to be very high, leading to the projected debt surge by almost 39 percent of GDP in advanced G-20 economies.

Conventional wisdom before the financial crisis was that monetary policy should be the anchor of macroeconomic policy as based on independent central banks with clear and well-defined objectives, leaving fiscal policy to a follower role. Charles Wyplosz argues in Monetary implications of the crisis: dominance at stake that the unusual events following the financial crisis are threatening the dominance position of monetary policy. Public finance problems are affecting the scope for monetary policy not only via the unconventional monetary policy initiatives taken, but also via their macroeconomic implications. Governments need to focus on fiscal discipline, and may therefore rely on central banks to deliver countercyclical policies and possibly even weigh on them to provide relief through inflationary finance. The monetary policy dominance in place is therefore under threat. It has become clear that central banks have no choice but to bail out systemically important financial institutions. This blurs the distinction between monetary and fiscal policy, and is possibly the biggest threat to monetary policy dominance. The paper also explores some of the issues that arise when the zero lower bound for the interest rate binds.

In recent policy debates, the importance of well-defined and transparent fiscal policy frameworks has been much stressed, as it has also been by several authors in this volume. In the debate, reference is often made to Sweden, which during the 1990s, faced a deep crisis with severe public finance 
problems that prompted a significant consolidation effort. This policy shift led to the development of The Swedish fiscal policy framework, which is explained and detailed in the paper by Robert Boije, Albin Kainelainen and Jonas Norlin. It is noteworthy that Sweden, despite being severely affected by the financial crisis and having rather strong automatic stabilizers, as well as pursuing an active fiscal stabilization policy, is not facing a public finance crisis in the aftermath of the financial crisis. This suggests that other countries could have something to learn from the Swedish fiscal policy framework. 


\title{
Some lessons for fiscal policy from the financial crisis*
}

\author{
Philip R. Lane ** $^{*}$
}

\section{Summary}

The current crisis calls for a reassessment of the optimal conduct of macroeconomic policies during non-crisis normal times. In particular, the risk and costs of crises can be mitigated by macroeconomic policies that lean against the wind in the face of cyclical, sectoral and external shocks. In this paper, I discuss the challenges involved in deploying fiscal policy in pursuit of a broad definition of macroeconomic stabilisation. The main policy conclusion is that pro-stabilisation fiscal policies are likely to be more effective if fiscal policy is determined under a formal fiscal framework that combines a set of fiscal rules and a substantive role for an independent fiscal policy council.

The global economic and financial crisis that has gripped the world since Summer 2007 has naturally generated much questioning about the conduct of economic policies during the pre-crisis period (and, indeed, the quality of the economic research that is supposed to provide a basis for policymaking). The response to the crisis has involved aggressive orthodox and nonorthodox monetary policies, plus fiscal stimulus packages in many countries. With the passing of the most acute phases of the crisis, attention is now turn-

\footnotetext{
${ }^{*}$ Prepared for the conference Fiscal Consequences of the Crisis, Copenhagen, March 22nd 2010, organised by the Nordic Economic Policy Review. I thank Donal Mullins, Christiane Hellmanzeik and Barbara Pels for helpful research assistance. I am grateful for detailed feedback from conference participants and the editorial team. This paper forms part of a research project on An Analysis of the Impact of European Monetary Union on Irish Macroeconomic Policy, funded by the Irish Research Council on Humanities and Social Sciences (IRCHSS).

${ }^{* *}$ IIIS, Trinity College Dublin and CEPR
} 
ing to optimal exit strategies for both monetary and fiscal policies, while it is also timely to reassess the appropriate macroeconomic policies for the resumption of normal times.

In this paper, my focus is on the latter question. In particular, I address the implications of the crisis for the optimal design of fiscal policy. One obvious motivation is that better-run macroeconomic policies during the precrisis period may have reduced the likelihood of such a crisis occurring and the possible scale of the crisis. In addition, not all countries were able to proactively use fiscal policy to offset the negative demand shock from the global recession. Following the typology of Spilimbergo et al. (2008), these countries lacked the fiscal space to respond to the crisis - the lesson to be drawn is that fiscal policy during normal times must be sufficiently sustainable and counter-cyclical to enable aggressive fiscal intervention in the event of a major negative shock.

Although the optimal conduct of monetary policy also requires serious revision, it is important to devote serious research attention to fiscal policy. The heated debate during the crisis across the different schools of macroeconomics about the conceptual foundations and empirical magnitudes of fiscal multipliers underlines the limited knowledge and understanding in the economics profession in relation to the potential effectiveness of fiscal policy. Moreover, fiscal policy is especially important in environments in which monetary or exchange rate policies cannot be effectively deployed. This applies to members of a monetary union or a pegged exchange rate system in relation to macroeconomic stabilisation at a country level. It also applies more generally in situations in which orthodox monetary policy is redundant, as when interest rate policy hits the zero bound.

It is not possible to cover all dimensions of the fiscal policy research agenda in this paper. Instead, I highlight a small number of key issues. First, I discuss the implications of the crisis for the optimal cyclical conduct of fiscal policy. Second, I argue that the scope of the stabilisation function of fiscal policy ought to be expanded beyond the output cycle, in order to respond to the emergence of excessive sectoral or external imbalances. Third, I propose that the current crisis has reinforced the case for reform of the institutional frameworks which guide the formation of fiscal policy. These issues are addressed in turn in Sections 1, 2 and 3. Some concluding comments are offered in Section 4. 


\section{Fiscal cyclicality}

In order to contribute to macroeconomic stability, it is desirable that fiscal policy moves in a counter-cyclical pattern. The ideal pattern is that fiscal surpluses are accumulated during boom periods which, in turn, enables the running of fiscal deficits during downturns without threatening long-term fiscal sustainability.

Such principles are easy to state. However, their application is not so straightforward. First, while the traditional focus has been on GDP cycles, fluctuations in asset markets and the sectoral composition of output are also relevant in determining the optimal stance for fiscal policy. One basic reason is that tax revenues are sensitive to the distribution of output across different sectors. For instance, it is well understood that the United Kingdom was heavily reliant on the high profitability and high labour incomes in the financial services industry as a source of tax revenue. In the Irish case, tax revenues during the 2002-2007 boom period were highly reliant on transactions-based taxes in the property sector and on capital gains taxes that were high during a period of rapid asset price appreciation.

More generally, high asset prices can amplify tax revenues through several channels. At a direct level, capital gains and wealth taxes increase when asset prices improve. Indirectly, high asset prices boost consumption and investment through positive wealth and balance sheet effects. Furthermore, the level of turnover in asset markets is typically increasing in the level of asset prices, such that the revenues from transaction taxes also grow.

The importance of asset prices and wealth shocks for tax revenues has been documented for a panel of countries by Eschenbach and Schuknecht (2004). In the Irish case, Addison-Smyth and McQuinn (2009) calculate a substantial tax windfall from the 2002-2007 housing boom in Ireland that was fuelled by capital inflows. More generally, Morris et al. (2009) show that revenue windfalls are more likely when output is growing strongly, such that revenue surprises tend to amplify the normal cyclical variation in revenues.

Accordingly, the optimal fiscal balance is not just a function of the output gap but also needs to take into account the temporary nature of the extra tax revenues that may be generated by unbalanced growth episodes in which asset prices are growing quickly and/or high-income sectors grow disproportionately quickly. Under such conditions, a larger fiscal surplus is appropri- 
ate in view of the temporary nature of windfall revenues and risks of sudden stops in activity level in such sectors.

Second, decisions about the appropriate stance for fiscal policy must be taken in a fog of uncertainty. Along one dimension, it is non-trivial to decompose output between cyclical and trend components. Along another dimension, it is vital to consider the distribution of risks around the central forecast, rather than focusing exclusively on the expected path for output.

In relation to the first point, the identification of the trend output path for a small and highly open economy is bound to carry a large standard-error band. International mobility of capital and labour means that the potential level of production can shift quite rapidly. In particular, international factor mobility means that persistent positive shocks are likely to endogenously increase the productive capacity of the economy, while persistent negative shocks will induce a downward shift in potential output. In related fashion, permanent trend shocks have an amplified impact through the endogenous movement of capital and labour across borders.

Such trend volatility combines with cyclical fluctuations. Cyclical shocks can be driven by temporary production or demand shocks. In addition, the impact effect of current or anticipated trend shocks is also to induce cyclical fluctuations since the associated inter-sectoral or international resource reallocations do not occur instantaneously. Regardless of their source, cyclical shocks generate temporary shifts in wages, prices and employment levels that may depart from efficient levels due to a variety of nominal and real rigidities.

Accordingly, it is extremely challenging to obtain a precise estimate of the relative contributions of cyclical and trend factors in determining macroeconomic outcomes in a given period. Still, the joint analysis of a variety of wage, price and activity indicators may provide a reasonable projection of the cyclical condition of the economy.

Moreover, in relation to policymaking, it is essential to incorporate the distribution of risks around such a central forecast. In particular, a macroprudential approach to setting fiscal policy would recognise the importance of providing insurance against downside risks.

As indicated above, one particular type of risk relates to cyclical drivers that are prone to sudden stops. Most obviously, activity levels that are driven by a combination of rising asset prices and a credit boom are typically characterised by a boom-bust cycle. Rising collateral values stimulate new 
credit-financed investment projects that deliver a sustained expansion phase until a trigger event leads to a revision in expectations and a sustained decline in investment that is amplified by a fall in collateral values and an increase in the cost of credit (see, amongst others, Geanakoplos, 2009). During the expansion phase, the reversal risk may be low for a given planning period but is cumulatively large over a longer horizon. For this reason, the fiscal strategy should take into account macroeconomic risks over a range of horizons, not just vis-à-vis the next annual budget cycle.

However, beyond the technical difficulties in correctly assessing the cyclical state of the economy and the distribution of fiscal risks, it is apparent that the discretionary components of fiscal policy have a procyclical bias in many countries (see, amongst others, Lane, 2003, and Agnello and Cimadomo, 2009). Accordingly, even if the government is fully aware of the current cyclical position, political economy factors may induce it to act in a pro-cyclical manner.

There are two main types of explanation for fiscal pro-cyclicality. First, the capacity to issue public debt may covary negatively with the state of the business cycle - under such circumstances, a government may be compelled by conditions in the capital market to tighten fiscal policy during a recession. While the primary focus has been on the importance of this channel for developing countries, the current financial crisis has underlined that funding costs and funding risks may also increase during recessionary periods even for high-income countries. In principle, this problem has a solution: a farsighted government would run sufficiently large surpluses during good times in order to avoid reliance on issuing debt during downturns.

Second, political distortions may generate a procyclical pattern in the fiscal position. For instance, Tornell and Lane (1999) highlight the voracity effect mechanism. In a political system with fragmented political power, a positive income shock leads to more intense lobbying by each powerful group. Since any individual group does not internalise the impact of its spending/tax demands on the overall fiscal situation, the collective outcome is that spending patterns are pro-cyclical - an $X$ percent increase in resources leads to a greater than $X$ percent increase in spending. In contrast, a coordinated fiscal system does not exhibit such a pro-cyclical pattern and spending is less volatile than income under this first-best benchmark. Lane (2003) presents some suggestive evidence that fragmented political systems gener- 
ate more fiscal pro-cyclicality. Talvi and Vegh (2005) and Alesina et al. (2008) provide complementary explanations.

According to these authors, voters require the government to cut taxes or raise spending on public goods during booms, in order to constrain the political temptation to divert boom-year revenues towards transfers for politically favoured elites or 'rents' for politicians. In this way, the solution to the agency problem is for voters to call for a pro-cyclical pattern in fiscal policy. While this is suboptimal in terms of the volatility of consumption, it is efficient in terms of limiting the waste of public resources on socially useless political rents.

A feature of these political economy models is that the pro-cyclicality bias tends to be more severe, the greater is the level of macroeconomic volatility. In a relatively stable economy, the amplitude of the business cycle may be sufficiently low to run a surplus in the low single digits during boom periods. However, in a more volatile economy, the higher amplitude of the cycle may call for substantially larger surpluses during expansion phases. Macroeconomic volatility tends to be higher in smaller, more globalised economies due to the limited level of domestic diversification and the elasticity of international factor flows.

Across the research contributions on fiscal pro-cyclicality, a common refrain is that such political distortions can be mitigated by the existence of effective fiscal rules and fiscal institutions. If fiscal policy is determined in an institutional environment that insulates the common interest from the adverse impact of sectoral lobbying or political rent seeking, such distortions can be neutralised and a fiscal policy with better cyclical properties can be attained. We return to this topic in Section 3.

\section{Fiscal policy, sectoral imbalances and balance sheet risks}

It is apparent that the incidence of the global economic crisis has been most severe for those countries that experienced rapid credit growth and ran large current-account deficits during the pre-crisis period (Lane and MilesiFerretti, 2010). In particular, the reversal in capital flows has meant that demand has been compressed in the deficit countries, thereby amplifying the impact of the global recession on living standards. While the increased dispersion in current-account imbalances during the pre-crisis period may have 
been in part justified by a genuine improvement in the level of international financial integration, the vulnerability of deficit countries to sudden stops has reignited the debate about whether macroeconomic policy should lean against the wind in order to discourage the emergence of excessive external imbalances.

In one direction, fiscal policy may itself be a source of external imbalances through several mechanisms. The standard intertemporal model of the current account predicts that a temporary increase in government spending will result in a current account deficit, since households opt to smooth private consumption rather than to respond to the surge in government absorption via a decline in private absorption (Sachs, 1982; Obstfeld and Rogoff, 1995). A similar pattern also holds in the baseline new open economy macroeconomic model. In this type of sticky-price general equilibrium model, a temporary increase in government consumption boosts domestic demand, thus generating a current account deficit and real appreciation (Obstfeld and Rogoff, 1996; and Corsetti and Mueller, 2008).

In relation to the financing of public spending, an increase in public debt may be associated with an increase in external debt if the conditions required for Ricardian equivalence do not hold. This is demonstrated in the models developed by Ganelli (2005) and Kumhof and Laxton (2009), in which households have finite horizons, such that a debt-financed tax cut increases the wealth of currently alive cohorts, thereby boosting consumption and generating a current-account deficit. Furthermore, Corsetti and Mueller (2008) show that the addition of an investment channel reinforces the passthrough from a fiscal deficit to an external deficit in the case of persistent deficits, especially for more open economies.

Kumhof and Laxton (2009) also show that qualitatively similar results apply in relation to a temporary increase in the fiscal deficit even in an infinite-horizon framework if some proportion of households are credit constrained. Under these conditions, a debt-financed tax cut boosts the current consumption of credit-constrained or hand-to-mouth consumers, thereby leading to a current-account deficit. These authors also show that a permanent increase in public debt is associated with a permanent decline in the net foreign asset position in the finite-horizon model. This prediction is supported by the empirical work of Lane and Milesi-Ferretti (2002).

In relation to other empirical evidence, Benetrix and Lane (2010) show that an increase in government spending is associated with an expansion in 
the relative size of the nontraded sector and a deterioration in the trade balance for a sample of EMU member countries. Related results for the trade balance are also reported by Lane and Perotti (1998), Corsetti and Mueller (2008) and Beetsma et al. (2008). Further evidence concerning the impact of fiscal policy on the current account is provided by Feyrer and Shambaugh (2009). They identify fiscal shocks in the United States by reference to the narrative approach developed by Romer and Romer (2008). Their estimate is that 50 percent of an unexpected tax cut is passed through to an increase in the US current-account deficit.

In the other direction, fiscal policy can facilitate external adjustment, regardless of the original source of the external imbalance. This is especially relevant for countries which operate under a currency peg or inside a monetary union, such that the nominal devaluation option is not available. The empirical evidence is that a contraction in public expenditure can generate a decline in the relative price of nontradables and a real depreciation at both short and long horizons (Lane and Perotti, 2003; Ricci et al., 2008; Beetsma et al., 2009; Galstyan and Lane, 2009; Benetrix and Lane, 2009).

In this regard, it is noteworthy that the empirical evidence indicates a robust relation between government spending and the real exchange rate. At medium- and long-term horizons, the cointegration analysis of Ricci et al. (2008) and Galstyan and Lane (2009) shows that a sustained decline in government consumption (relative to trading partners) is associated with real depreciation. ${ }^{2}$ A similar result is obtained in annual data by Lane and Perotti (2003). In addition, in relation to the financing of the fiscal position, the evidence in the preceding section was that, all else being equal, an improvement in the fiscal balance should be associated with a partial improvement in the external balance. Accordingly, a government may also facilitate external adjustment by improving the fiscal balance.

In an environment in which a real devaluation is required in order to boost net exports but a nominal devaluation is not possible, a cut in the level of public-sector wages may be especially helpful in accelerating the required adjustment. A cut in public-sector wages promotes wage adjustment in the

\footnotetext{
${ }^{2}$ Galstyan and Lane (2009) also consider the long-run relation between public investment and the real exchange rate. Since a higher stock of public capital may affect productivity in the traded and nontraded sectors, its impact on the real exchange rate is ambiguous. In the data, there is little robust evidence of a strong link between public investment and the real exchange rate.
} 
private sector, both through direct competition for workers across sectors but also through a demonstration effect.

While there is considerable resistance to the notion of nominal wage reductions, some of the main frictions do not apply to coordinated wage reductions across the public sector. For instance, the negative morale effect identified by Bewley (1999) relates to the relative status of workers: if there is a general wage reduction across the public sector, the relative positions of different groups of public-sector workers would be unchanged. Similarly, the holdup problem analysed by MacLeod and Malcomson (1993) and Holden (1999) refers to the localised bilateral bargaining problem between an employer and workers - wages may be rigid in the face of sector-specific issues but flexible in response to macroeconomic factors.

Moreover, such wage flexibility is more feasible in a social partnership infrastructure under which unions factor in macroeconomic conditions in wage negotiations. Such an encompassing deal would be less feasible in a non-coordinated setting in which the government must deal with individual public-sector unions in a decentralised fashion. There is also a stated fear in some quarters that nominal wage reductions may induce a deflationary spiral that will only serve to deepen the current recession. However, deflation is self-correcting for an individual member of a pegged exchange rate system or monetary union, since the cumulative real depreciation ultimately boosts economic activity levels and associated inflationary pressures.

In Ireland, there has been a considerable reduction in public-sector pay over the last two years, with the scale of the pay cuts increasing in the level of wages. While this adjustment may have been desirable, it necessitated the introduction of new legislation, since the existing wage contracts did not allow for such downward revisions. It would have been better to redesign pay contracts upon entry into EMU in 1999, in order to provide explicit recognition that negative macroeconomic conditions may occasionally require nominal pay reductions.

In particular, a two-part pay scheme may be preferable. Under such a system, part A of a salary would be fully protected against downward adjustments - this component would provide the employee with a level of income insurance for planning purposes. In contrast, part B of a salary would be a state-contingent payment. Under an adverse shock, the part B payment could be reduced or eliminated in response to a set of defined trig- 
ger events, such as a contraction in GDP or tax revenues beyond given threshold levels.

A trade-off exists. The larger the share of total compensation that is allocated to the part A component, the greater is the stability of nominal incomes but the lower is the degree of nominal flexibility. In exchange for greater stability, the average level of pay should be set at a lower level since the employer is in effect providing income insurance to employees and will need to build up a precautionary reserve fund to smooth out fluctuations. In contrast, average pay can be set at a higher level if the part B component represents a more significant fraction of total compensation, since total pay can be downwardly adjusted in the event of a negative shock.

If such a state-contingent pay system were introduced for public-sector workers, this would make fiscal policy a more effective instrument for macroeconomic stabilisation, in view of the key role for wage adjustment in minimising persistent unemployment. In relation to the private sector, similar multi-part payment contracts may spread in reaction to such an innovation in the public sector or as part of a new type of social partnership agreement. While the prevalence of bonuses and other types of discretionary payments in some private-sector industries means that there is already some scope for downward pay flexibility, these are typically linked to firm- or industry-specific performance indicators rather than to macroeconomic factors. From an economy-wide perspective, a state-contingent component in private-sector pay deals that is linked to national macroeconomic conditions would facilitate macroeconomic adjustment.

So far, this discussion has focused on the role of fiscal flows (spending, taxes, the deficit). In addition, fiscal policy may be deployed to address balance sheet problems in the banking, corporate and household sectors with the net acquisition of financial assets by the government periodically deployed to bail out distressed private-sector entities or to take these into public ownership. Such private-sector financial problems are more likely to occur if external or sectoral imbalances have accumulated. For instance, rapid credit growth and significant external debt levels characterise those economies that have suffered the most severe financial distress during the current crisis. More generally, prior lending booms are a significant predictor of subsequent banking and currency crises (Reinhart and Rogoff, 2009).

Through such bailout operations, the public balance sheet may be transformed by the level of gross public debt or contingent liabilities jumping in 
a discrete fashion. In turn, such rescue packages may increase funding costs for the government and also constrain public spending and taxation decisions.

While such interventions may be conditionally optimal given the circumstances (rescuing a banking sector from imminent collapse), a forwardlooking fiscal strategy should incorporate the risk of such events in determining the optimal level of net public debt during normal times. In addition, it may be useful to accumulate a liquid rainy-day fund to provide for such interventions. Along these lines, Lane (1998) advocated the establishment of a rainy-day fund upon Ireland's entry into EMU in order to provide some pre-funding in the event of a subsequent banking crisis.

In the Irish case, no such rainy-day fund was established. However, the National Pensions Reserve Fund (NPRF) was established in 2001 in order to accumulate assets with the goal of pre-funding the long-term increase in ageing-related public spending after 2025. ${ }^{3}$ Although its mandate was to invest commercially on a global basis, a substantial proportion of its net value was recently redirected towards the recapitalisation of the two main Irish banks. In this way, the NPRF was redeployed as a rainy-day fund, despite its stated long-term mission.

While the existence of a rainy-day fund does carry moral hazard risks, it is also the case that the capacity of a government to fund a rescue package through new debt issuance may not be available when it is needed - the same types of shocks that generate private-sector financial distress may also be associated with tough funding conditions in the sovereign debt market.

Recent proposals to tax bank profits in order to accumulate an insurance fund are similar in terms of objectives.

Note that rainy-day funds can also support other counter-cyclical policies. As is discussed in Calmfors (2003), Finland set up a rainy-day fund upon entry into EMU that accumulates extra social security contributions from employers during upswings in order to enable a lower contribution rate during downturns. This smoothing policy supports the stabilization of employment over the cycle.

In relation to risk of banking-sector distress, the other lesson is that it is fiscally costly to permit the emergence of excessive external and sectoral

\footnotetext{
${ }^{3}$ In addition to initial funding from the proceeds of the privatisation of the national telecoms operator, the government allocates one percent of GNP each year to the NPRF.
} 
imbalances that add to the fragility of private-sector balance sheets. This provides a motivation to engage in preventive operations to limit the scale of such imbalances.

Such interventions can be justified by a variety of distortions that limit the capacity of the private sector to self-correct excessive imbalances. In general, individual decisions by debtors and creditors on the accumulation of debt liabilities cannot fully take into account the systemic risks that a function of the economy-wide aggregate balance sheet and the correlations in investment decisions across all types of entities.

In relation to the external account, Summers (1988) and Blanchard (2007) have argued that financial constraints mean that a contraction in tradables output during a period of high domestic expenditure may not be easily reversed once the economy needs to make the transition towards greater net exports. In addition, high net inflows may increase the risk of a sudden stop and the attendant risk of financial distress. For these reasons, economic policy should lean against the wind, in order to limit the scale of external imbalances.

A wide range of preventive policies can contribute to a more stable and balanced pattern of economic growth. Most obviously, macro-prudential financial regulation can limit banking-sector instability and excessive procyclicality in lending practices (see also Geanakoplos 2009). However, this is an incomplete approach to the extent that non-bank financial firms, nonfinancial corporates and households can directly obtain credit from external funders.

For countries with independent monetary policies, interest rate policy can in principle also contribute to the stabilisation of asset markets. However, it is open to question whether interest rate policy can be effectively deployed to this end and whether the cost would be too high in terms of deviating from the core objective of targeting inflation (Assenmacher-Wesche and Gerlach, 2010).

Accordingly, part of the responsibility for preventive stabilisation may fall to the fiscal authority. In relation to the real estate sector, fiscal intervention may take the form of counter-cyclical taxes on property transactions as recommended by Fitzgerald (2001). In relation to the external account, Blanchard (2007) shows how the timing of government spending on nontradables and tradables may be optimally manipulated to limit the distortions induced by current-account imbalances. In addition, the government can 
target the current-account balance via a number of instruments. First, a government that wishes to narrow a current-account deficit could run a more positive fiscal balance. Second, even at an unchanged fiscal balance, a reduction in government absorption can improve the external balance.

Third, tilting the schedule for particular types of taxes can alter the timing of consumption and investment decisions and thereby improve the current external balance. For instance, a reduction in employment taxes contributes to real depreciation by lowering the cost of domestic labour (Calmfors, 2003). A further type of microeconomic intervention is to alter the timing of consumption decisions through subsidies to saving schemes, which mimics the impact of a shift in the interest rate. ${ }^{4}$

The current crisis has underlined the high costs of a "do nothing" attitude towards the management of imbalances. Accordingly, a major challenge for future research is to assist in the design of optimal intervention strategies for sectoral stabilisation.

Of course, the implementation problems are quite substantial in terms of correctly identifying the emergence of excessive imbalances and working out the optimal timing and scale of policy interventions. In part, one type of reform is to modify and strengthen automatic stabilisers in order to deliver greater stability in a passive manner. However, automatic stabilisers will not be sufficient to deal with all types of shocks, such that the design and implementation of optimal discretionary fiscal interventions is also an important element of the policy toolkit.

\section{Reforming the fiscal framework}

The preceding analysis has highlighted that the conduct of fiscal policy has been revealed by the global crisis to have been far from optimal during the pre-crisis period. In part, the quality of public finances was insufficiently robust to enable an unfettered fiscal response to the crisis, at least in some countries due to a failure to run the required fiscal surpluses during the good

\footnotetext{
${ }^{4}$ While Ireland introduced the Special Savings Incentive Account (SSIA) scheme in 2001 to cool down the booming economy, the design of this scheme was not targeted at cyclical stabilisation. Most important, its fixed five-year horizon meant that the withdrawal of the subsidy in 2006/2007 was independent of the cyclical state of the economy. In contrast, a cyclically focused scheme would have specified a subsidy schedule that was conditioned on cyclical indicators.
} 
years. In part, fiscal policy was passive in the face of the accumulation of sectoral and external imbalances in a number of countries. The net result was that the severity of the crisis was exacerbated by the deficiencies of fiscal policy during the pre-crisis years.

These problems suggest that the fiscal process requires reform. In particular, it is possible that a redesigned fiscal framework that combines fiscal rules and an independent fiscal council could deliver superior macroeconomic stabilisation. The formalisation of the fiscal process could help to mitigate the political distortions that can derail the setting of public spending and taxation. Moreover, the conduct of fiscal policy in pursuit of macroeconomic stabilisation is technically demanding, which requires considerable input from independent fiscal specialists.

There is some evidence that stronger fiscal rules are correlated with superior fiscal performance. European Commission (2009) estimates that those countries that adopt stronger fiscal rules are more successful in improving their structural fiscal balance. A similar result is also obtained by Fabrizio and Mody (2006) for a different panel of countries and a different index for the quality of budgetary institutions. Related evidence is provided by Beetsma et al. (2009), who show that fiscal balances are more positive in countries with stronger fiscal rules. However, it is also important to appreciate the limitations to the empirical work in this area. In particular, Debrun and Kumar (2007) highlight the difficulties in obtaining identification, since the adoption of a rules-based system may be more likely in countries that would attain good fiscal outcomes even under a discretionary system.

Moreover, the analysis of the European Commission (2009) also emphasises common problems in the design of fiscal rules. Ex-post independent monitoring of compliance with fiscal rules is not widespread and there is little by way of sanctions in the event of non-compliance. In relation to central governments, many of the rules focus on expenditure growth, whereas the main cyclical problem in most economies is how to handle unexpected revenue windfalls.

The current crisis has also illustrated the brittle nature of many of these rules, since the specification of the rules typically did not cater for the occurrence of major non-standard shocks. An important lesson is that fiscal rules typically should include escape clauses that make clear the conditions under which the normal operation of a rule is suspended (see also Mody and Stehn, 
2009). However, it is important that such deviations are only triggered in the event of genuine shocks, in view of the obvious potential for abuse.

In terms of further evidence concerning the efficacy of fiscal rules, Chile provides an especially relevant case study (see, amongst others, FfrenchDavis, 2010). It adopted a new fiscal framework in 2001, which was subsequently codified in the 2006 Fiscal Responsibility Law. Under this framework, the Chilean government must run a structural fiscal surplus. Moreover, the state of the business cycle is evaluated by an expert committee such that the government must operate under this independently determined constraint. During 2004-2008, Chile ran a cumulative fiscal surplus of 28.5 percent of GDP, with the Treasury becoming a significant net creditor (fiscal liabilities were small, while the assets accumulated were substantial). By building up a war chest during the boom years, Chile was able to meet the 2009 recession with a vigorous counter-cyclical policy: there was a 14.5 percent real growth in public spending in 2009, despite a 28.5 percent fall in fiscal revenue. (The projected 2009 overall fiscal balance was a four percent deficit.)

The preceding discussion of fiscal rules has underlined that such rules are more effective if independent agencies play an active role in the fiscal policy process. More generally, the key to insulating the fiscal process from procyclicality pressures is to find institutional devices that enable governments to maintain the cyclically appropriate fiscal stance.

However, as has been highlighted by Wyplosz (2008), there are so far relatively few examples of effective fiscal policy councils. ${ }^{5}$ One interpretation is that the concept is relatively new and that such councils will become increasingly prevalent in the coming years, with the rate of adoption stimulated by the current fiscal crises in many countries. Another is that there may be resistance among lobby groups to the establishment of a fiscal policy council, since a shift towards a more long-sighted fiscal process would limit the access of such groups to debt-financed tax breaks or spending programmes.

The current crisis presents a window of opportunity to introduce such institutional reforms, since it has revealed in dramatic fashion the costliness of

\footnotetext{
${ }^{5}$ See also the discussions in Calmfors (2008 and 2010) in relation to the lessons from the Swedish Fiscal Policy Council.
} 
the discretionary approach to fiscal policy that was practiced in many countries during the pre-crisis years.

The appropriate fiscal framework involves both fiscal rules and a central role for an independent fiscal council. In relation to the specification of fiscal rules, a priority is to set a target for the structural balance, even if the precise target may vary across countries with different initial conditions and different long-term fundamentals.

However, the structural balance fiscal rule should contain an escape clause by which a structural fiscal deficit is permitted in the event of a sufficiently large negative shock. Such an escape clause provides the flexibility to address major recessions, which may require extra fiscal measures beyond the automatic stabilisers that are part of the passive cyclical component of the budget. In terms of defining the conditions that would activate the escape clause, this could be delegated to an independent fiscal policy council in order to ensure that it is only triggered by truly exceptional shocks.

Moreover, a rules-based approach should enhance of counter-cyclical fiscal interventions.

It should also be recognized that estimating the structural balance in real time is subject to considerable uncertainty, in view of the non-observability of the level of potential output. Accordingly, it is important to incorporate this uncertainty about the level of the structural balance into short-term decisions over fiscal policy, with the structural balance more appropriately considered a useful medium-term indicator of the fiscal stance. In the short term, fiscal uncertainty can manifest itself by revenue outcomes that deviate from projected levels. A key principle of fiscal prudence is that windfall revenue gains are saved rather than mapped into unplanned increases in the level of public spending.

An important consideration is that the short-term effectiveness of fiscal policy critically depends on long-term fiscal sustainability: if an increase in spending today signals a long-term increase in the tax burden, its positive demand effects will be negated (Favero and Giavazzi, 2007; Corsetti et al., 2008). Accordingly, a credible rules-based framework that ensures that temporary fiscal injections will be subsequently unwound will enhance the effectiveness of the fiscal boost by removing doubt about the long-term sustainability of the fiscal position.

This main fiscal rule could be augmented by some ancillary rules. One candidate ancillary rule could relate to the establishment of a rainy-day fund 
that could finance a structural deficit under the exceptional circumstances outlined in the preceding paragraph. By holding a buffer stock of liquid assets, the financing of exceptional deficits by such a fund could avoid the need to seek fresh borrowing during those periods in which funding costs and funding risk are least favourable. The rainy-day fiscal rule could specify a target steady-state value for the fund (as a ratio to GNP). Moreover, the rule could specify that surprise revenue windfalls should be paid into the fund and surprise revenue shortfalls paid out of the fund. In this way, the rainy-day fund could play a "leaning against the wind" role in dealing with unanticipated revenue fluctuations. Moreover, a rules-based approach to dealing with revenue surprises is strongly advocated by European Commission (2009).

In relation to the appropriate role for an independent fiscal council, a partial list of tasks may include estimation of the cyclical state of the economy and the distribution of macroeconomic risk factors. In particular, an independent fiscal council may advise or issue a determination on an ex-ante basis concerning the appropriate cyclical fiscal balance. Alternatively, it may hold the government to account on an ex-post basis for the choices it has made concerning the cyclical operation of fiscal policy.

In view of the difficult analytical challenges in determining the appropriate fiscal responses to the incipient emergence of sectoral or external imbalances, an important additional task may be to determine the conditions under which such imbalances require fiscal intervention. Moreover, an independent fiscal council could specify the types of fiscal interventions that may be required to correct excessive imbalances. In turn, this may require a considerable research effort to design the appropriate fiscal instruments and calibrate the required adjustments to public spending and taxation.

In terms of setup, it is important that the fiscal policy council is an independent institution, for the same types of reasons that justify the independence of central banks.

However, it is also vital that a fiscal policy council is accountable. Accountability can be made effective by a two-track process. First, the members of the fiscal policy council should testify before the relevant parliamentary committee on a regular basis and explain clearly any errors in the projections and analyses made by the council. Second, the technical quality of the work produced by the fiscal council should be audited by regular reviews carried out by an international expert group. In this way, such a group would 
perform the same type of role as played by the Independent Evaluation Office of the International Monetary Fund.

Finally, it is desirable to match the Swedish practice of including some non-nationals in the membership of the council, since this expands the range of potential members and provides a mechanism to learn from the fiscal experience in other countries.

\section{Conclusions}

The goal of this paper has been to highlight how the global crisis should lead to a re-assessment of the optimal conduct of fiscal policy during normal noncrisis times. First, the severe costs of the crisis signal that it is vital to run a prudent fiscal policy that not only operates in a counter-cyclical manner but also has a structural balance and level of fiscal debt that can permit a country to engage in aggressive fiscal interventions in the event of a severe negative shock. In addition, the cyclical conduct of fiscal policy must incorporate the distribution of macroeconomic risks, in addition to the central projection of the current cyclical state of the economy.

Second, the stabilisation role for fiscal policy is not only related to the output cycle, but should also respond to excessive sectoral and external imbalances, in view of the risks to macroeconomic and fiscal stability embedded in such imbalances. In tandem with macro-prudential financial regulation, a wide range of fiscal interventions could help to tackle such imbalances, especially in environments in which monetary policy is rendered ineffective.

Third, pro-stabilisation fiscal policies are more likely to be successful if the fiscal policy is conducted within a formal fiscal framework that combines a set of fiscal rules with a substantive role for an independent fiscal policy council. While such ideas have been in circulation for quite some time, the current crisis provides an opportunity to consider them more seriously and broaden the scope of such fiscal frameworks, even in countries which have already partially implemented such fiscal reforms.

Finally, it is important to acknowledge that the current crisis has also revealed the poor state of our knowledge about the empirical evidence concerning the effectiveness of fiscal interventions. In addition to research on the normative issues that have been the main focus of this paper, it is a high 
priority to improve our empirical understanding of how fiscal policy affects macroeconomic outcomes.

\section{References}

Addison-Smyth, D. and McQuinn, K. (2009), Quantifying revenue windfalls from the Irish housing market, Research Technical Paper 10/RT/09, Central Bank and Financial Services Authority of Ireland.

Agnello, L. and Cimadomo, J. (2009), Discretionary fiscal policies over the cycle, ECB Working Paper 1118, Frankfurt.

Alesina, A., Campante, F. and Tabellini, G. (2008), Why is fiscal policy often procyclical?, Journal of the European Economic Association 6, 1006-1036.

Assenmacher-Wesche, K. and Gerlach, S. (2010), Monetary policy and financial imbalances: Facts and fiction, Economic Policy, forthcoming.

Beetsma, R., Giuliodori, M. and Wierts, P. (2009), Budgeting versus implementing fiscal policy in the EU, Economic Policy, forthcoming.

Benetrix, A. and Lane, P.R. (2009), Fiscal Shocks and the Real Exchange Rate, IIIS Discussion Paper 286.

Benetrix, A. and Lane, P.R. (2010), Fiscal shocks and the sectoral composition of output, Open Economies Review 21, 335-350.

Bewley, T. (1999), Why Wages Don’t Fall During a Recession, Harvard University Press, Cambridge, MA.

Blanchard, O. (2007), Current account deficits in rich countries, IMF Staff Papers 54, 191-219.

Corsetti, G. and Mueller, G. (2008), Twin deficits, openness and the business cycle, Journal of European Economic Association 16, 404-413.

Calmfors, L. (2003), Fiscal policy to stabilise the domestic economy in the EMU: What can we learn from monetary policy?, CESifo Economic Studies 49, 3-19.

Calmfors, L. (2008), Comment on Charles Wyplosz: Fiscal policy councils: Unlovable or Just unloved?, Swedish Economic Policy Review 15, 193-197.

Calmfors, L. (2010), The Swedish Fiscal Policy Council - experience and lessons, manuscript, Institute for International Economic Studies, Stockholm.

Debrun, X. and Kumar, M.S. (2007), The discipline-enhancing role of fiscal institutions: Theory and empirical evidence, IMF Working Paper 07/171, Washington, D.C.

Eschenbach, F. and Schuknecht, L. (2004), Budgetary risks from real estate and stock markets, Economic Policy 39, 313-346.

European Commission (2009), Fiscal rules, independent institutions and medium-term budgetary frameworks, Chapter 4in Public Finances in EMU - 2009, Luxembourg.

Fabrizio, S. and Mody, A. (2006), Can budget institutions counteract political indiscipline?, Economic Policy 21, 689-739.

Favero, C. and Giavazzi, F. (2007), Debt and the effects of fiscal policy, NBER Working Paper 12822.

Feyrer, J. and Shambaugh, J.C. (2009), Global savings and global investment: The transmission of identified fiscal shocks, NBER Working Paper 15113. 
Ffrench-Davis, R. (2010), Latin America: The structural fiscal balance policy in Chile: A move towards counter-cyclical macroeconomics, Journal of Globalization and Development 1, Article 14.

Fitzgerald, J. (2001), Managing an economy under EMU: The case of Ireland, The World Economy 24,1353-1371.

Galstyan, V. and Lane P.R. (2009), The composition of government spending and the real exchange rate, Journal of Money, Credit and Banking 41, 1233-1249.

Geanakoplos, J. (2009), The leverage cycle, NBER Macroeconomics Annual, forthcoming.

Holden, S. (1999), Renegotiation and the efficiency of investments, Rand Journal of Economics 30, 106-119.

Kumhof, M. and Laxton, D. (2009), Fiscal deficits and current account deficits, IMF Working Paper 09/237, Washington, D.C.

Lane, P.R. (1998), Irish fiscal policy under EMU, Irish Banking Review, Winter, 2-10.

Lane, P.R. (2003), The cyclicality of fiscal policy: Evidence from the OECD, Journal of Public Economics 87, 2661-2675.

Lane, P.R. and Perotti, R. (1998), The trade balance and fiscal policy in the OECD, European Economic Review 42, 887-895.

Lane, P.R. and Perotti, R. (2003), The importance of composition of fiscal policy: Evidence from different exchange rate regimes, Journal of Public Economics 87, 2253-2279.

Lane, P.R. and Milesi-Ferretti, G.M. (2002), Long-term capital movements, NBER Macroeconomics Annual 16, 73-116.

Lane, P.R. and Milesi-Ferretti, G.M. (2010), The cross-country incidence of the global crisis, IMF Economic Review, forthcoming.

MacLeod, W.B. and Malcomson, J.M. (1993), Investments, holdup, and the form of market contracts, American Economic Review 83, 811-837.

Mody, A. and Stehn, S.J. (2009), Germany's new fiscal rule: A responsible approach to fiscal sustainability, VoxEU.org.

Morris, R., de Castro Fernández, F., Jonk, S., Kremer, J., Linehan, S., Marino, M.R., Schalck, C. and Tkacevs, O. (2009), Explaining government revenue windfalls and shortfalls: An analysis for selected EU countries, ECB Working Paper 1114, Frankfurt.

Obstfeld, M. and Rogoff, K. (1995), The intertemporal approach to the current account, in G. Grossman and K. Rogoff (eds.), Handbook of International Economics, Vol. III, North-Holland.

Obstfeld, M. and Rogoff, K. (1996), Foundations of International Macroeconomics, MIT Press, Cambridge, MA.

Reinhart, C. and Rogoff, K. (2009), This Time It's Different, Princeton University Press, Princeton, New Jersey.

Ricci, L., Milesi-Ferretti, G.M. and Jaewoo, L. (2008), Real exchange rates and fundamentals: A cross-country perspective, IMF Working Paper 08/13, Washington, D.C.

Romer, C. and Romer, D. (2008), A narrative analysis of postwar tax changes, manuscript, University of California at Berkeley, CA.

Sachs, J. (1982), The current account in the macroeconomic adjustment process, Scandinavian Journal of Economics 84, 147-159. 
Spilimbergo, A., Symansky, S., Blanchard, O. and Cottarelli, C. (2008), Fiscal policy for the crisis, IMF Staff Position Note 08/01, Washington, D.C.

Summers, L.H. (1988), Tax policy and international competitiveness, in J. Frenkel (ed.) International Aspects of Fiscal Policies, University of Chicago Press, Chicago, IL.

Talvi, E. and Vegh, C.A. (2005), Tax base variability and procyclical fiscal policy in developing countries, Journal of Development Economics 78, 156-190.

Tornell, A. and Lane P.R. (1999), The voracity effect, American Economic Review 89, 22-46.

Wyplosz, C. (2008), Fiscal policy councils: Unlovable or Just unloved?, Swedish Economic Policy Review 15, 173-192. 



\title{
Fiscal policy and macroeconomic stability: New evidence and policy implications*
}

\author{
Xavier Debrun and Radhicka Kapoor ${ }^{* *}$
}

\section{Summary}

In this paper we revisit the empirical link between fiscal policy and macroeconomic stability. Our basic presumption is that by definition, the operation of automatic stabilizers should always and everywhere contribute to greater macroeconomic stability (output and consumption). However, two stylized facts seem at odds with that prediction. First, the moderating effect of automatic stabilizers appears to have weakened in advanced economies between the mid-1990s and 2006 (the end of our main sample). Second, automatic stabilizers do not seem to be effective in developing economies. Our analysis addresses these apparent puzzles. Two salient features of our approach

Keywords: Macroeconomic stability, fiscal policy, automatic stabilizers. JEL Classification Numbers: E61, E62.

\footnotetext{
* The views expressed in this paper are those of the authors and do not necessarily represent those of the IMF or IMF policy. Without implication, we thank Antonio Afonso, Torben Andersen, Thomas Baunsgaard, Helge Berger, Olivier Blanchard, Mark de Broeck, Luc Everaert, Antonio Fatàs, Davide Furceri, Steinar Holden, Albert Jaeger, Yngve Lindh, Mats Persson, and seminar participants at the IMF, the Banca d'Italia, and the Nordic Economic Policy Review conference for stimulating comments and suggestions.

** Xavier Debrun, International Monetary Fund, and Radhicka Kapoor, London School of Economics.
} 
are (1) a systematic test for the government's ambivalent role as a shock absorber and a shock inducer - thereby removing a downward bias present in existing estimates of the impact of automatic stabilizers - and (2) accounting for determinants of macroeconomic volatility over time. The results provide strong support for the view that fiscal stabilization operates mainly through automatic stabilizers. Moreover, the destabilizing impact of policy changes not systematically related to the business cycle may not be as robust as suggested in the literature. We also provide tentative evidence that automatic stabilizers were the main channel of fiscal stabilization during the great recession of 2009. 
Recent developments in macroeconomic modeling and pressing policy challenges have revived the classic debate on the effectiveness of fiscal policy as an instrument of macroeconomic stabilization (van der Ploeg, 2005). On the theory side, the rapid development of micro-founded general equilibrium models with non-Ricardian features has allowed researchers to assess the benefits of fiscal stabilization in a coherent and rigorous analytical framework (see Botman et al., 2006, for a survey). These studies confirm the conventional wisdom that a timely countercyclical response of fiscal policy to demand shocks is likely to deliver appreciably lower output and consumption volatility (Kumhof and Laxton, 2009). However, well-intended fiscal activism can also be undesirable, when shocks predominantly affect the supply side (Blanchard, 2000), or squarely destabilizing, when information, decision and implementation lags unduly lengthen the transmission chain. On the policy side, a growing number of countries turned to fiscal policy as their primary stabilization instrument either because of changes in their monetary regime (currency board, hard peg, participation in a monetary union) or because financial conditions deteriorated to the point of rendering monetary policy ineffective (Spilimbergo et al., 2008).

Fiscal policy can contribute to macroeconomic stability through three main channels. The first is an automatic reduction in government saving during downturns and an increase during upturns, thereby cushioning shocks to national expenditure (Blinder and Solow, 1974). Such automatic stabilization occurs because tax revenues tend to be broadly proportional to national income and expenditure, whereas public spending reflects government commitments independent of the business cycle and entitlement programs specifically designed to support spending during downturns, including unemployment benefits. ${ }^{1}$ Furthermore, to the extent that government consumption is less volatile than other components of GDP, the public sector contributes to output stability through a mere composition effect of domestic expenditure. Second, governments can deliberately change public spending and tax instruments to offset business-cycle fluctuations. Third, the structure of the tax and transfer system can be designed to maximize economic efficiency and market flexibility, thereby enhancing the resilience of the econ-

\footnotetext{
${ }^{1}$ Darby and Mélitz (2008) and Furceri (2009) show that social spending-including health and retirement benefits - is more countercyclical than generally acknowledged. For instance, early retirement and sick leave — which often protect employees against involuntary separation — are more likely to be used during downturns.
} 
omy in the face of shocks. The notion of fiscal stabilization pertains to the first two channels.

The public's demand for government-induced stability reflects a number of factors that may vary over time and across countries, including the inherent resilience of the economy and the existence of alternative stabilizers, such as an effective monetary policy and unrestricted access of individual agents to financial instruments. During the recent crisis, the perceived need for fiscal stabilization has been unquestionably high. The resilience of national economies was impaired by the depth and the global nature of the shock, agents faced either limited access to or high cost of self-insurance through credit markets and financial institutions, and the firepower of monetary policy was constrained by the zero-bound on nominal interest rates. In the short term, the stabilizing role of fiscal policy relies on effective automatic stabilizers and on the capacity of governments to engineer (and credibly phase out) a fiscal stimulus in a timely fashion.

This paper puts the current revival of fiscal stabilization policies in a broader perspective by revisiting the contribution of fiscal policy to macroeconomic stability in both industrial and developing economies over the last 40 years. The study builds on earlier work by Galì (1994), van den Noord (2002) and Fatás and Mihov (2001, 2003), who investigate directly the cross-country relationship between fiscal policy indicators and output volatility. That approach has the advantage of incorporating, in simple statistical tests, various determinants of the stabilizing effect of fiscal policy, including policymakers' "reaction functions" and the actual impact of fiscal measures on output and private consumption. The resulting, reduced-from empirical relations thus provide useful information on the effectiveness of fiscal policy, while avoiding the methodological issues associated with the estimation of fiscal "multipliers." Indeed, multipliers estimates are highly sensitive to the identification procedure of exogenous fiscal impulses (structural VARs, narratives, or DSGE model simulations), the nature of the shock (tax cuts, spending increases), and the behavior of monetary policy (Blanchard and Perotti, 2002; Perotti, 2005; Romer and Romer, 2008; and Horton, Kumar and Mauro, 2009, for a survey).

Existing analyses of fiscal stabilization tend to focus on the role of automatic stabilizers in industrial economies. Many of them draw on the seminal insights of Galì (1994) and revolve around the negative relationship between output volatility and government size, used as a proxy for the cyclical sensi- 
tivity of the budget balance. While the literature generally confirms the countercyclical impact of automatic stabilizers, the relationship appears to be complex. First, non-linearities seem to exist, ${ }^{2}$ thus suggesting that the adverse effect of high tax rates on an economy's resilience could more than offset the action of automatic stabilizers. Second, the relationship may be changing over time as structural changes moderating output volatility could be faster in economies with leaner governments. ${ }^{3}$ Third, the relationship does not seem to hold beyond a narrow sample of industrial OECD countries. ${ }^{4}$ Debrun, Pisani-Ferry and Sapir (2008) addressed the first two concerns, by introducing a time dimension in the Fatás-Mihov sample to control for potential determinants of the "great moderation," (i.e., the steady decline in output volatility observed between the mid-1980s and the recent past). Their results confirm the effectiveness of automatic stabilizers in reducing output volatility.

Here we look further into the robustness of the results described above. Our contribution rests on four elements. First, our sample includes 49 industrial and developing countries for which reasonably long time series exist for fiscal data covering the general government. Second, we take into account the potentially destabilizing impact of fiscal policy, as public finances are used to attain other goals than macroeconomic stability. Should bigger governments produce larger fiscal shocks, estimates of the impact of automatic stabilizers would be biased. Third, we account for the role of potential substitutes to fiscal policy as a macroeconomic insurance mechanism, including financial development, improved monetary policy credibility, and better economic policy governance. These variables may account for the decline in output volatility observed until the recent crisis and may prove important to properly identify the causal relation between automatic stabilizers and volatility (see Debrun, Pisani-Ferry, and Sapir, 2008, and Mohanty and Zampolli, 2009). Fourth, we investigate the extent to which fiscal policy contrib-

\footnotetext{
${ }^{2}$ Examples include Silgoner, Reitschuler and Crespo-Cuaresma (2002) and Martinez-Mongay and Sekkat (2005).

${ }^{3}$ Debrun, Pisani-Ferry and Sapir (2008) and Mohanty and Zampolli (2009) document an apparent breakdown of the relationship between government size and output volatility in the 1990s.

${ }^{4}$ Fatás and Mihov (2003) find that government size actually increases output volatility in a cross section of 91 countries. Virén (2005), using an even larger cross section of 208 countries and territories, concludes that "the relationship between government size and output volatility is either nonexistent or very weak at best.” Mohanty and Zampolli (2009) find that even among OECD countries, government size only has a modestly negative impact on output volatility.
} 
utes to lower private consumption volatility, as the latter is more closely related to welfare.

The main results can be summarized as follows. First, automatic stabilizers strongly contribute to output stability regardless of the type of economy (advanced or developing), thus confirming the effectiveness of timely, predictable and symmetric fiscal impulses in stabilizing output. The impact on private consumption volatility is quantitatively weaker and statistically less robust. Second, countries with more volatile cyclically adjusted budget balances also exhibit more volatile output and private consumption. However, the result could be tainted by a reverse causality problem that we could not satisfactorily address with instrumental-variables techniques due to a weakinstrument problem. Third, access of individual consumers to credit appears to exert a stabilizing influence on output and private consumption. A weaker contribution of credit supply to smooth cyclical fluctuations could thus increase the public's appetite for fiscal stabilization.

The rest of the paper is structured as follows. In Section 1 we discuss data issues and review stylized facts. The econometric analysis is developed in Section 2. We consider the results and draw some policy implications in the concluding section.

\section{Data and stylized facts}

\subsection{Governments as shock absorbers and shock inducers}

The size of automatic stabilizers is commonly approximated by the ratio of general government expenditure to GDP. Using a rule of thumb according to which the elasticity of government revenues and expenditure (both in levels) to the output gap is 1 and 0 , respectively, the expenditure-to-GDP ratio is indeed equal to the semi-elasticity of the overall budget balance (in percent of GDP) to the output gap ${ }^{5}$.

However, if size matters for automatic stabilization, it could also prove harmful for macroeconomic stability if bigger governments tend to produce larger fiscal shocks than their leaner counterparts. To avoid an omittedvariable bias, it is important to control for this possibility in econometric

\footnotetext{
${ }^{5}$ See equations (1) and (2) below.
} 
analyses. In the remainder of this sub-section we construct a set of mutually consistent fiscal indicators capturing three relevant dimensions of fiscal policy: automatic stabilizers, systematically stabilizing discretionary policy, and non-systematic policy (which can be stabilizing or not).

\section{Three dimensions of fiscal policy}

When examining the cyclical properties of the overall budget balance, it is common to split it into two components: the cyclical balance and the cyclically adjusted balance (see, for instance, Galì and Perotti, 2003). Changes in the cyclical balance give an estimate of the budgetary impact of aggregate fluctuations through the induced changes in tax bases and certain mandatory outlays. By construction, the cyclical balance is zero when the output gap is closed (actual output is on trend), and its variations are thought to be outside the immediate control of the fiscal authorities. Subtracting the cyclical balance from the overall balance yields the cyclically adjusted balance (CAB), or the hypothetical overall balance that would be observed if output were on trend (or "potential") level. Changes in the CAB are generally interpreted as resulting mostly ${ }^{6}$ from discretionary actions by policymakers.

The CAB itself reflects two dimensions of fiscal policy relevant for our analysis. The first is the effect of policy decisions systematically related to changes in the actual or expected cyclical conditions of the economy. For instance, governments wishing to actively pursue a countercyclical policy could reduce taxes or increase government consumption whenever the economy is in a recession, while withdrawing the stimulus during the recovery and reducing public spending during booms. The response of the $\mathrm{CAB}$ to the cycle can either be pro-cyclical (running against automatic stabilizers) or countercyclical (augmenting the effect of automatic stabilizers). The second source of variations in CABs arises from budgetary changes that are not the result of the average response of fiscal authorities to the business cycle. This “exogenous” CAB can either reflect extraordinary fiscal stabilization efforts - such as those adopted in response to the recent crisis - or destabilizing fiscal impulses associated with other objectives of public finances (redistri-

\footnotetext{
${ }^{6}$ Studies of the fiscal stance often exclude interest payments, as they reflect past policies (public debt) and financial conditions.
} 
bution and efficiency), or non-economic considerations (e.g., electoral budget cycle).

Henceforth, we discuss fiscal policy in light of these three dimensions of the overall balance:

- automatic stabilizers;

- "cyclical fiscal policy", reflecting the systematic response of the CAB to the business cycle; and

- "exogenous discretionary fiscal policy" capturing $\mathrm{CAB}$ changes that are not systematically related to current macroeconomic conditions ${ }^{7}$.

\section{Quantifying the three dimensions}

Data analysis alone does not allow disentangling the impact of automatic stabilizers from that of systematic discretionary stabilization. We solve this identification problem by simply assuming that automatic stabilizers are adequately measured by the ratio of public expenditure to GDP. Such an assumption enhances the comparability of our results with related studies and provides a simple and transparent metric applicable to all countries. But it entails a potential measurement error that should be kept in mind when interpreting the results.

A CAB consistent with our assumption is needed to derive indicators of the "cyclical" and exogenous policies defined above. As indicated earlier, government size is an exact measure of the sensitivity of the budget balance to the business cycle if revenue and expenditure elasticities to output are 1 and 0 , respectively. To see this, define the CAB (in percentage of trend output $\left.Y^{*}\right)$ as:

$$
\begin{aligned}
C A B & \equiv \frac{R\left(Y^{*} / Y\right)^{\eta_{R}}}{Y} \frac{Y}{Y^{*}}-\frac{G\left(Y^{*} / Y\right)^{\eta_{G}}}{Y} \frac{Y}{Y^{*}} \\
& =r\left(Y^{*} / Y\right)^{\eta_{R}-1}-g\left(Y^{*} / Y\right)^{\eta_{G}-1},
\end{aligned}
$$

${ }^{7}$ This is the terminology used by Fatás and Mihov (2009). For a more detailed discussion of cyclical adjustment, see Fedelino, Ivanova and Horton (2009). 
where $r$ is total revenue as a ratio of GDP $(Y), Y^{*}$ is the trend level of output, $\eta_{R}$ is the elasticity of revenue to the output gap, $g$ is the expenditure to GDP ratio, and $\eta_{G}$ is the elasticity of expenditure to the output gap. Setting $\eta_{R}=1$ and $\eta_{G}=0$ and denoting by $b$ the overall budget balance (in percent of GDP) yields:

$$
\begin{aligned}
C A B & =r-g\left(Y^{*} / Y\right)^{-1} \\
& =b-g\left(Y^{*} / Y\right)^{-1}+g \\
& =b-g\left(Y / Y^{*}-1\right) \\
& =b-g y,
\end{aligned}
$$

where $y$ is the output gap in percentage of trend output $\left(y \equiv\left(Y-Y^{*}\right) / Y^{*}\right)$, and $g y$ is the cyclical balance. This formally establishes that the public expenditure ratio is the semi-elasticity of the budget balance (in percent of GDP) to the output gap. ${ }^{8}$

Indicators of the cyclical and exogenous/discretionary fiscal policies can thus be estimated for each country in our sample, using a simple time-series regression: ${ }^{9}$

$$
C A B_{t}=\alpha+\beta \gamma_{t}+\gamma C A B_{t-1} \mu_{t}
$$

where the output gap $y_{t}$ is calculated as the relative deviation of actual GDP from an HP trend. The first-order autoregressive term on the right-hand side of (3) accounts for persistence in budget balances, and effectively eliminates the severe first-order serial correlation of residuals observed in static regressions.

The cyclical fiscal policy is captured by $\beta$, the short-term response of the $\mathrm{CAB}$ to the output gap. A negative value implies that a cyclical upturn (downturn) tends to deteriorate (improve) the $\mathrm{CAB}$, thereby indicating that

\footnotetext{
${ }^{8}$ Of course, this does not mean that automatic stabilizers arise from the expenditure side since we assumed $\eta_{G}=0$.

${ }^{9}$ Galì and Perotti (2003), Wyplosz (2006) and Fatàs and Mihov (2009) use a similar specification to study the cyclical features of fiscal policy. Fatàs and Mihov (2003) and Afonso, Agnello and Furceri (2009) also rely on a regression-based method to distinguish between cyclicality, persistence, and the volatility of public expenditure.
} 
government actions are systematically destabilizing and offset - at least partly - the impact of automatic stabilizers on the economy. On the other hand, a positive coefficient on $y_{t}$ implies that on average, the government seeks to increase the counter-cyclical bent of fiscal policy through discretionary measures.

The effectiveness of fiscal policy entails reverse causality from CAB to $y$, introducing a downward bias in OLS estimates of $\beta$. In addition, equation (3) is parsimonious by necessity (time series are short in some countries), which could create an omitted variable bias. To alleviate potential biases in the estimated $\beta$ 's, instrumental variable (IV) techniques are used. Instruments for the output gap include its own lagged value, log-differenced terms of trade and oil prices, and energy use per capita. ${ }^{10} \mathrm{~A}$ priori, these are adequate instruments - especially for small open economies - as cyclical fluctuations are correlated with terms of trade shocks, oil prices and energy use per capita, without being directly influenced by the fiscal stance. For oil exporters, however, we used the lagged value of the output gap, the output gap of the United States, and its lagged value. ${ }^{11}$

The exogenous discretionary policy is calculated as the variability (standard deviation) of a residual $\hat{\zeta}_{t}=C A B_{t}-\hat{\alpha}-\hat{\beta} y_{t}-\hat{\gamma}(C A B)_{t-1}$, where $\hat{\alpha}, \hat{\beta}$, and $\hat{\gamma}$ are obtained from IV estimation. This differs from the standard error of residuals in equation (3), $\sigma_{i}^{\mu}=\sqrt{\operatorname{var}_{i}\left(\hat{\mu}_{t}\right)}$

The reason is that, having instrumented the output gap, the residual of (3) would incorporate the non-instrumented part of the output gap, $\left(\hat{\beta}\left(y_{t}-\hat{y}_{t}\right)\right)$ thus introducing co-movement between our measure of discretionary policy and output gap volatility. This would, in turn, create a simultaneity bias in the regressions performed to estimate the effect of fiscal policy on output gap variability. By their very nature, these residuals capture more than discretionary policy decisions, including measurement errors, and the direct budgetary impact of certain shocks over and above their influence on economic activity (for instance, exchange rate fluctuations affecting interest

\footnotetext{
${ }^{10}$ Lee and Sung (2007) estimate the responsiveness of fiscal policy to cyclical fluctuations, taking the average of GDP growth rates in neighboring countries, weighted by the inverse of the distance between the two countries, as an instrument.

${ }^{11}$ There are five oil-producing countries in the sample. Ideally, the non-oil fiscal balances should be used in the regression. However, no sufficiently long time series were available to obtain meaningful estimates of $\beta$. Dropping these countries from the sample does not alter the results.
} 
payments and commodity-related revenues, the influence of asset prices on certain revenue categories, and inflation shocks). The notion of "exogenous discretionary policy" should therefore be interpreted with caution. While equation (3) could be augmented to account for some of these effects, the measurement of pure shocks raises other issues that would ultimately alter the transparency of our simple approach.

\section{Caveats}

In interpreting our empirical results, one should keep in mind that government size is only an approximation of the cyclical sensitivity of the budget balance. To assess the likelihood of any bias introduced by that proxy, we look at the relation between the public expenditure to GDP ratio and the

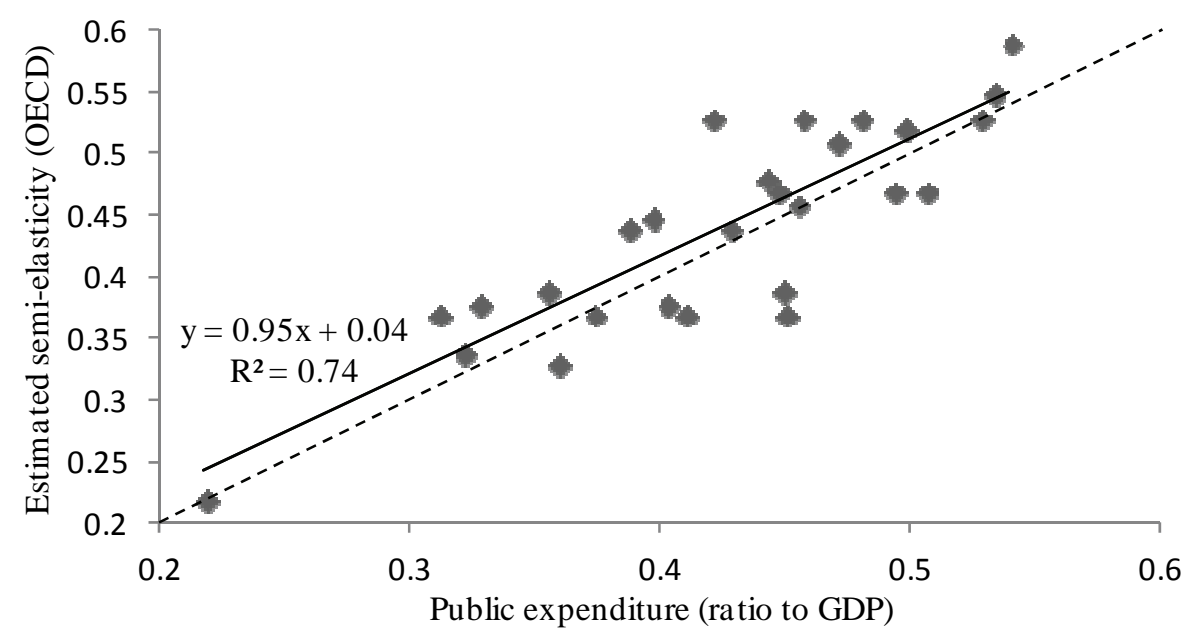

Figure 1. Government size and cyclical sensitivity of the budget balance (OECD) Sources: Girouard and André (2005) and authors' calculations.

semi-elasticities of the budget balance to the output gap estimated by the OECD for most of its member countries (Figure 1). These estimates partly take into account the impact of tax progressivity and cyclically sensitive expenditure. ${ }^{12}$ The regression line is statistically indistinguishable from a

\footnotetext{
${ }^{12}$ Some ad-hoc assumptions remain, however, including a unit-elasticity of indirect taxes and a zero-elasticity for expenditure except unemployment benefits. The latter may be a strong assumption in light of Darby and Mélitz (2009) who show that social spending other than unemployment
} 
45-degree line, indicating that government size is a reliable proxy for automatic stabilizers in OECD countries.

Outside the OECD, however, lower output sensitivities may prevail. On the revenue side, a greater share of indirect taxes in revenues and a lower degree of progressivity in direct taxes tend to weaken the responsiveness of tax revenues to income. On the expenditure side, unemployment insurance and other social safety nets are generally less developed. Given this, we may overestimate the size of automatic stabilizers in developing countries, while underestimating their impact on output and consumption volatility. We would correspondingly overestimate the stabilizing influence of cyclical fiscal policy, as $\hat{\beta}$ would capture any measurement error in the size of automatic stabilizers. Another issue is that short time series limit our ability to test for the presence of structural breaks in the relation between the CAB and the output gap. In general, tests conducted for OECD countries - for which we have time series starting in 1970 - do not allow us to reject the null hypothesis that $\beta$ is stable between two sub-periods (1970-89 and 19902006).

\subsection{Output volatility and automatic stabilizers: stylized facts}

The seminal studies by Galì (1994) and Fatás and Mihov (2001) suggest that the effectiveness of automatic stabilizers is already evident from the negative unconditional correlation between real GDP growth variability and the size of government, and they show this for a sample of selected OECD countries between 1960 and the early 1990s. Our broader sample, which covers selected developing economies and ends in 2006, exhibits a similar correlation (Figure 2, top panel). Subsequent analyses qualified this result, suggesting that the relation is likely to be non-linear and unstable over time. Using the same set of countries as Fatás and Mihov (2001), Debrun, PisaniFerry and Sapir (2008) document a dramatic weakening of the negative rela- 


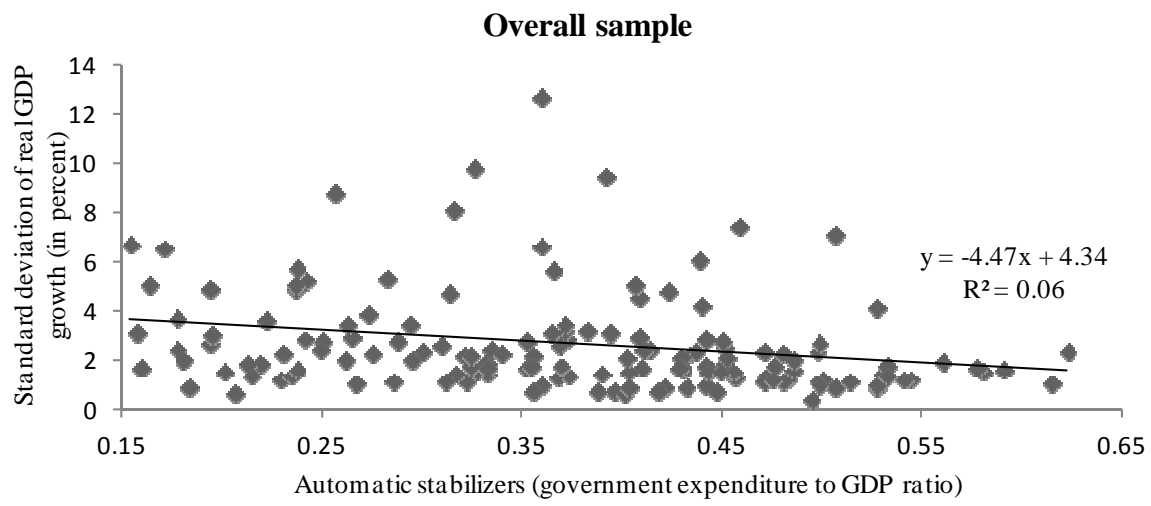

\section{Advanced OECD}

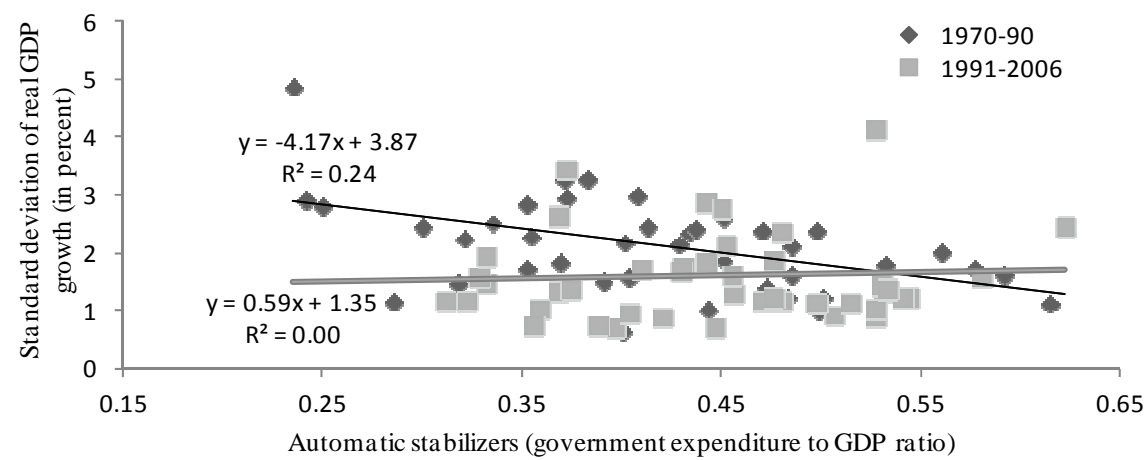

\section{Developing countries}

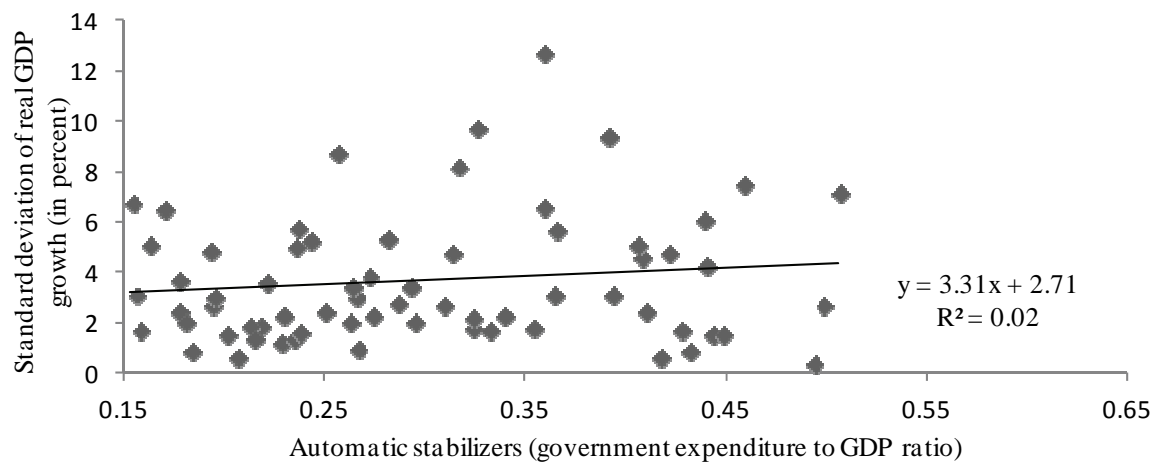

Figure 2. Automatic stabilizers and output volatility (1970-2006)

Note: each observation represents a combination of government size and real GDP growth volatility observed in one country over a given decade. Source: Authors' calculations. 
tion after the mid-1990s, a stylized fact present in our sample for advanced OECD countries (Figure 2, center panel). Econometric analysis by the same authors also revealed non-linearities in this relation, thus implying strongly decreasing returns in automatic fiscal stabilization beyond a certain threshold of government size. Silgoner, Reitschuler and Crespo-Cuaresma (2003), and Martinez-Mongay and Sekkat (2005) found similar non-linearities in a sample of EU member states.

Although the literature generally supports the effectiveness of automatic stabilizers in OECD countries, some studies have suggested that the result may not hold in developing economies. In particular, Virén (2005) finds that the negative relation between government size and GDP volatility does not exist when developing economies are included in the sample. Using our sample, scatter plots indeed depict a weakly positive correlation for the subset of developing countries (Figure 2, bottom panel).

These stylized facts raise two questions. First, it is unclear why automatic stabilizers per se would be subject to strong "decreasing returns." ${ }^{13}$ Second, even if government size exaggerates the magnitude of automatic stabilizers in developing countries, the existence of a positive relationship remains counterintuitive. Both puzzles are consistent with the need to take into account the shock-inducing aspect of fiscal policy. The appearance of decreasing returns could indeed result from the fact that bigger governments generate more destabilizing fiscal shocks, as documented in Debrun and Kapoor (2010). Likewise, the apparent ineffectiveness of automatic stabilizers in developing countries may have to do with more pervasive institutional weaknesses and political economy constraints in these countries that magnify the shock-inducing part of fiscal policy to the point of overcoming automatic stabilizers.

Another interesting characteristic of the relation between output volatility and government size is that it seems to be evolving over time, which empasizes the importance of examining possible causes for such evolution. Debrun, Pisani-Ferry and Sapir (2008) show that the factors driving the trend decline in output volatility until the recent crisis - the so-called great moderation - were more powerful in countries with smaller government sectors than

${ }^{13}$ That said, in a reduced-form IS-curve, the relation between output and the size of automatic stabilizers is log-linear because the fiscal impulse stemming from the operation of stabilizers itself depends on output (see the Appendix). 

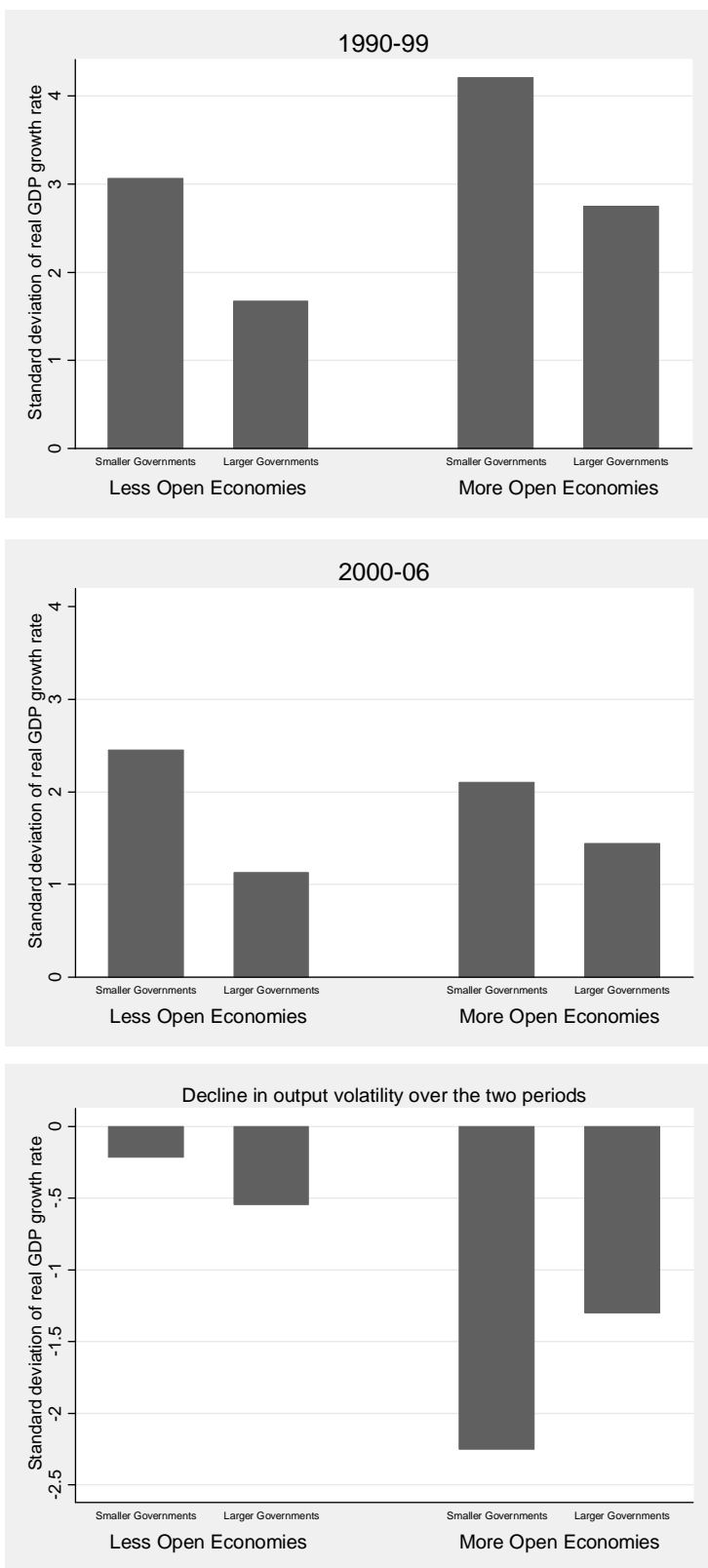

Figure 3. Output volatility over time

Source: Authors' calculations. 
others. We can verify this in our broader sample by dividing countries into four categories along two dimensions: trade openness and government size (cut-off levels are the median values). We consider only the last two periods of our sample 1990-99 and 2000-06 to cover all the countries.

For both sub-periods, output volatility is on average larger in countries with smaller governments, regardless of trade openness (Figure 3). Rodrik's (1998) observation that more open economies are generally more volatile is verified for 1990-99, but not for the more recent period. Indeed, the bottom panel of Figure 3 shows that the decline in average output volatility between the two sub-periods has been more pronounced in more open economies, and among the latter in countries with smaller governments. This suggests that open economies with smaller governments took better advantage of the factors driving the great moderation, such as improved access to financial instruments, credit and external financing, thereby allowing economic agents to better smooth consumption and plan investment. However, openness tends to raise the economic cost of policy mistakes, which may contribute to better macroeconomic management, including more countercyclical macroeconomic policies.

\section{Econometric analysis}

\subsection{Testing the effectiveness of automatic stabilizers}

Following Fatás and Mihov (2001), the empirical test is based on the crosscountry relation between government size and output volatility. As we also take into account time-varying factors that may affect the public's demand for fiscal stabilization or the government's incentives to provide such stabilization (Debrun, Pisani-Ferry and Sapir, 2008), the baseline empirical model is a panel regression with period-fixed effects: ${ }^{14}$

\footnotetext{
14 The time dimension comprises four periods over which annual data have been averaged (1970-79, 1980-89, 1990-99 and 2000-06). The panel is unbalanced because of data limitations for developing and emerging market economies. The Appendix reports data sources. Input from auxiliary regressions can be found in Debrun and Kapoor (2010).
} 
$Y_{i, t}=\alpha+\sum_{t=2}^{t=4} \lambda_{t} P_{t}+\phi_{1} G_{i, t}+\phi_{2} \operatorname{Cyc}_{i}+\phi_{3} \operatorname{Discr}_{i, t}+\sum_{j=1}^{J} \theta_{j} X_{j, i, t}+v_{i, t}$,

with $i=1, \ldots 49$ (countries) and $t=1, \ldots 4$ (10-year period). $Y_{i t}$ is a measure of real GDP volatility, the $P_{t}$ 's symbolize period-fixed effects, $G_{i t}$ denotes the size of automatic stabilizers (logarithm of public expenditure in percent of GDP), $C y c_{i}$ and Discr ${ }_{i t}$ are the cyclical and discretionary dimensions of fiscal policy discussed in Section 1 , the $X_{i}$ 's are control variables, and $v_{i t}$ is the error term. As the cyclicality indicator is an estimated coefficient, it is sometimes not statistically different from zero. To reduce the noise stemming from such uncertainty, we set $\mathrm{Cyc}_{i}$ equal to zero for countries where the $\hat{\beta}_{i}$ is statistically insignificant at the 10 percent confidence level. The discretionary dimension Discr $_{i t}$ is calculated for each sub-period to capture any change in the average magnitude of fiscal policy shocks nonsystematically related to the business cycle.

By default, we calculated output volatility as the standard deviation of real GDP growth over each period $t$. However, since this measure is sensitive to variations in potential growth (over time and across countries), we systematically checked the robustness of our results using the standard deviation of the first differenced output gap (calculated by us for all countries as the relative difference between actual real GDP and its HP-filtered series). The focus on aggregate output volatility - instead of privately generated GDP for instance - is justified by the fact that the contribution of fiscal policy to macroeconomic stability also operates through composition effects of national expenditure (Andrés, Doménech and Fatás, 2008). Although there is no evident theoretical reason for rejecting these effects, we also investigated the relationship between our fiscal indicators and the variability of private consumption because the latter is more directly related to welfare.

A rejection of the null hypothesis that $\phi_{1}=0$ against the alternative $\phi_{1}<0$ is consistent with the effectiveness of automatic stabilizers. In the Appendix, it is formally illustrated that, given a sample average of 0.38 for government size, plausible values of $\phi_{1}$ lie between -0.5 and -2.6. As we have more observations than most comparable studies, we are better placed to deal with the omitted-variables and reverse-causality issues inherent to a single-equation approach. More specifically, we introduce determinants of volatility that have been related to the "great moderation" episode 
and are suspected to have weakened the relation between government size and output volatility. We then assess the robustness of our results, and expand the analysis to private consumption volatility.

\subsection{Fiscal policy: shock-absorbing or shock-inducing?}

We first estimated a parsimonious model deliberately omitting discretionary and cyclical dimensions of fiscal policy as well as time-series determinants of output volatility (Table 1). The results are consistent with two stylized facts noted earlier. First, non-OECD-20 countries are both more volatile and have smaller governments, which explains why the standard stabilization result holds for the whole sample but not for the non-OECD-20 subset. Second, among the OECD-20 group, the effectiveness of automatic stabilizers seems to have decreased substantially over the last two decades.

Table 1. A parsimonious model

\begin{tabular}{lrrrr}
\hline \multirow{2}{*}{ Dependent variable: } & \multicolumn{1}{c}{$(1)$} & $(2)$ & $(3)$ & $(4)$ \\
& \multicolumn{1}{c}{ Standard deviation of real GDP growth rate } & & \\
\cline { 2 - 5 } & \multicolumn{1}{c}{ All } & Non-OECD & OECD (1970-89) & OECD (1990-2006) \\
\cline { 2 - 5 } Openness & 1.143 & .150 & $1.617^{*}$ & .720 \\
& $(1.323)$ & $(.110)$ & $(1.869)$ & $(1.174)$ \\
Automatic stabilizers & $-1.614^{\star * *}$ & 1.038 & $-2.224^{\star * *}$ & -.244 \\
Constant & $(-4.450)$ & $(1.350)$ & $(-2.784)$ & $(-.412)$ \\
& .728 & $5.614^{\star * \star}$ & -.418 & .675 \\
Observations & $(1.211)$ & $(3.194)$ & $(-.482)$ & $(.991)$ \\
R-squared & 152 & 75 & 37 & 40 \\
\hline
\end{tabular}

Note: Robust t-statistics in parentheses. Time effects are not reported. Stars denote statistical significance at conventional levels ( ${ }^{\star}$ for 10 percent, ${ }^{\star \star}$ for 5 percent, and ${ }^{\star \star \star}$ for 1 percent).

We conjectured earlier that omitting Discr $_{i t}$ could entail a serious upward bias in estimates of $\phi_{1}$ if bigger governments also tended to induce larger shocks. The results summarized in Table 2 - which now include all dimensions of fiscal policy and the time-series controls - lend support to that hypothesis: the size of government now has a negative and statistically significant impact on output volatility, and this prevails regardless of whether we restrict the sample to certain economies or sub-periods. The absolute values of $\hat{\phi}_{1}$ are higher than previously estimated, and the confidence intervals are 
narrower. They are also quantitatively similar to Fatás and Mihov (2001) around 2 - despite a very different sample.

Table 2. Introducing cyclical and discretionary dimensions of fiscal policy (Dependent variable: standard deviation of real GDP growth rate)

\begin{tabular}{|c|c|c|c|c|c|c|}
\hline & (1) & (2) & (3) & (4) & (5) & (6) \\
\hline & OECD-20 & $\begin{array}{r}\text { Non } \\
\text { OECD-20 }\end{array}$ & All & $\begin{array}{r}\text { All } \\
1970-89\end{array}$ & $\begin{array}{r}\text { All } \\
1990-2006\end{array}$ & All \\
\hline Openness & $\begin{array}{r}.717 \\
(1.56)\end{array}$ & $\begin{array}{l}.462 \\
(.48)\end{array}$ & $\begin{array}{l}.507 \\
(.79)\end{array}$ & $\begin{array}{l}-.389 \\
(-.33)\end{array}$ & $\begin{array}{r}.684 \\
(1.00)\end{array}$ & $\begin{array}{l}.519 \\
(.86)\end{array}$ \\
\hline Automatic stabilizers & $\begin{array}{r}-1.409 * * * \\
(-2.93)\end{array}$ & $\begin{array}{r}-1.605^{\star} \\
(-1.79)\end{array}$ & $\begin{array}{r}-2.013^{\star * *} \\
(-5.00)\end{array}$ & $\begin{array}{r}-1.290 * * \\
(-2.30)\end{array}$ & $\begin{array}{r}-2.257^{\star \star *} \\
(-3.89)\end{array}$ & $\begin{array}{r}-1.680 * \star \star \\
(-4.21)\end{array}$ \\
\hline Central bank independence & $\begin{array}{l}-.117 \\
(-.27)\end{array}$ & $\begin{array}{l}.715 \\
(.47)\end{array}$ & $\begin{array}{r}1.096^{*} \\
(1.79)\end{array}$ & $\begin{array}{l}.138 \\
(.18)\end{array}$ & $\begin{array}{l}1.404 \\
(1.63)\end{array}$ & $\begin{array}{r}-2.728^{\star \star \star} \\
(-2.62)\end{array}$ \\
\hline Financial development & $\begin{array}{c}-.446^{\star} \\
(-1.98)\end{array}$ & $\begin{array}{l}-.010 \\
(-.02)\end{array}$ & $\begin{array}{r}-.788^{\star \star *} \\
(-3.01)\end{array}$ & $\begin{array}{r}-.577 \\
(-1.08)\end{array}$ & $\begin{array}{l}-.770^{\star *} \\
(-2.56)\end{array}$ & $\begin{array}{l}-.550 * \star \\
(-2.20)\end{array}$ \\
\hline Cyclical fiscal policy & $\begin{array}{l}-.065 \\
(-.27)\end{array}$ & $\begin{array}{l}.209 \\
(.15)\end{array}$ & $\begin{array}{l}.114 \\
(.38)\end{array}$ & $\begin{array}{l}-.214 \\
(-.51)\end{array}$ & $\begin{array}{l}.030 \\
(.07)\end{array}$ & $\begin{array}{l}.026 \\
(.09)\end{array}$ \\
\hline Discretionary fiscal policy & $\begin{array}{l}.016 \\
(.16)\end{array}$ & $\begin{array}{r}.911^{\star \star \star} \\
(4.62)\end{array}$ & $\begin{array}{c}.672^{\star \star \star} \\
(4.64)\end{array}$ & $\begin{array}{r}.186 \\
(1.19)\end{array}$ & $\begin{array}{r}.877^{\star \star *} \\
(4.66)\end{array}$ & $\begin{array}{l}-.451^{\star} \\
(-1.79)\end{array}$ \\
\hline Interaction: discretion $\times$ CBI & $\ldots$ & $\ldots$ & $\ldots$ & $\ldots$ & $\ldots$ & $\begin{array}{r}2.118^{\star \star \star} \\
(3.83)\end{array}$ \\
\hline Constant & $\begin{array}{r}1.013^{\star *} \\
(2.13)\end{array}$ & $\begin{array}{l}-2.501 \\
(-1.17) \\
\end{array}$ & $\begin{array}{r}-1.134 \\
(-1.51) \\
\end{array}$ & $\begin{array}{r}.992 \\
(.423) \\
\end{array}$ & $\begin{array}{r}-2.617^{\star *} \\
(-2.42)\end{array}$ & \\
\hline Observations & 77 & 56 & 133 & 47 & 86 & 133 \\
\hline R-squared & .398 & .522 & .497 & .347 & .571 & .576 \\
\hline
\end{tabular}

Note: Robust t-statistics in parentheses. Time effects are not reported. Stars denote statistical significance at conventional levels ( ${ }^{\star}$ for 10 percent, ${ }^{* \star}$ for 5 percent, and ${ }^{* \star \star}$ for 1 percent).

These results differ from Fatás and Mihov (2003) who find that government size has a positive effect on volatility in a cross section of 91 countries. Their model is similar to (4) except that (i) they have no measure of $C y c_{i}$, (ii) the time dimension is missing, and (iii) their measure of Discr $_{i t}$ is based on public consumption only. Two important reasons for the difference are that our approach allows for a richer set of relevant determinants of volatility (e.g., financial development) and that it uses measures of automatic stabilizers, cyclical policy and discretionary policy that are mutually consistent and based on a broad coverage of the government sector.

While we fail to find any significant stabilizing impact of the cyclical dimension (a sign that this series may be too noisy), the coefficient $\hat{\phi}_{3}$ on the discretionary dimension is positive and significant for the unrestricted 
sample and for the sub-sample excluding the OECD-20. In contrast, $\hat{\phi}_{3}$ is not significantly different from zero in the OECD-20. Furthermore, the fit of the model increases substantially. These results suggest that discretionary fiscal policy is likely to be an important contributor to output volatility outside the core OECD economies covered in previous studies. This is in line with Fatás and Mihov (2003), although our measure of discretionary policy - based on budget balance volatility - is quite different from theirs - volatility of GDP-growth-adjusted public consumption.

An interesting observation is that the degree of central bank independence has a significantly positive impact on volatility, a result largely driven by the presence of the non-OECD-20 countries in the sample. This could suggest that anti-inflationary credentials take time to build up despite rising degrees of legal independence, or that productivity shocks and decision lags entail a meaningful trade-off between real and nominal stability.

Another possibility is that coordination failures in the policy mix could be more frequent when monetary and fiscal authorities independently pursue different objectives. Specifically, fiscal impulses unrelated to routine stabilization are more likely to lead to costly conflicts with monetary authorities when the latter are politically independent than when they are forced to accommodate fiscal shocks. To explore that conjecture, we added to the model an interaction term between the index of central bank independence (CBI) and our measure of exogenous fiscal policy. In the presence of the interaction term, the estimated coefficient of CBI turns negative and significant - as one would expect if CBI induces improvements in the quality of monetary policy - whereas the interaction term is positive and highly significant. One interpretation is that fiscal impulses not systematically related to output stabilization undermine the benefits of central bank independence, thus reflecting possible coordination failures in the policy mix. The fact that $\hat{\phi}_{3}$ also turns negative when the interaction term is present could indicate that such conflicts would be the main reason for the positive conditional correlation between fiscal discretion and output volatility. 
We also see that the moderating impact of financial development on output volatility is robust to the introduction of our fiscal controls although that effect is driven mainly by more recent (post-1990) observations.

\subsection{Robustness checks}

We now check the robustness of our results to common econometric issues, first examining the possibility of reverse causality, and then assessing the risk of an omitted-variable bias.

\section{Endogeneity}

Equations (4) and (5) are potentially subject to reverse causality problems. For instance, governments concerned with output stability could arguably adjust their fiscal behavior and the size of automatic stabilizers to the intensity of exogenous disturbances affecting the economy (Rodrik, 1998). Reverse causality could also bias estimated coefficients on CBI and financial development if more volatile economies are more inclined to delegate monetary policy to an independent agency with a clear stabilization mandate, and if private agents take better advantage of financial services to self-insure against the income effect of aggregate fluctuations.

Following Fatás and Mihov (2001, 2003), we selected instruments capturing institutional and structural characteristics of countries likely to be correlated with our explanatory variables but presumably orthogonal to output volatility itself. Institutional instruments include the electoral rule (proportional vs. majoritarian), the type of political system (presidential vs. parliamentary), the presence of political constraints (number of veto points in the government), and the distribution of ideological preferences. Other instruments are GDP per capita (at PPP, in log), the dependency ratio, the rate of urbanization, and a dummy variable identifying oil producers.

The specification used for 2SLS estimation is column (3) of Table 2. We instrumented potentially endogenous explanatory variables one by one, each time testing for the endogeneity of other suspicious instruments. ${ }^{15}$ Formal exogeneity tests (Wu-Hausman - WH) only rejected the null hypothesis that

\footnotetext{
${ }^{15}$ Instrumenting multiple right-hand-side variables did not yield any meaningful result, in large part reflecting the weak-instrument issue discussed below.
} 
OLS estimates are consistent for Discr $_{i t}$ (strongly) and the index of central bank independence (marginally), suggesting that 2SLS should be preferred over OLS (column (3) and (5) of Table 3). Testing for the orthogonality between each non-instrumented explanatory variable (i.e., the included instruments) and the error term broadly supports the conclusions of the WH tests.

Table 3. Two-stage-least-squares (2SLS) estimates (Dependent variable: standard deviation of real GDP growth rate)

\begin{tabular}{|c|c|c|c|c|c|}
\hline & (1) & (2) & (3) & (4) & (5) \\
\hline Instrumented variable: & $\begin{array}{l}\text { Automatic } \\
\text { stabilizers }\end{array}$ & $\begin{array}{r}\text { Cyclical fiscal } \\
\text { policy }\end{array}$ & $\begin{array}{r}\text { Discretionary } \\
\text { fiscal policy }\end{array}$ & $\begin{array}{r}\text { Financial } \\
\text { development }\end{array}$ & $\begin{array}{r}\text { Central bank } \\
\text { independence }\end{array}$ \\
\hline Openness & $\begin{array}{l}.528 \\
(.83)\end{array}$ & $\begin{array}{l}.472 \\
(.75)\end{array}$ & $\begin{array}{r}.491 \\
(0.74)\end{array}$ & $\begin{array}{l}.539 \\
(.85)\end{array}$ & $\begin{array}{l}.566 \\
(.79)\end{array}$ \\
\hline Automatic stabilizers & $\begin{array}{r}-2.271^{\star * *} \\
(-4.17)\end{array}$ & $\begin{array}{r}-2.169 * \star * \\
(-5.11)\end{array}$ & $\begin{array}{r}-1.948^{\star \star *} \\
(-4.07)\end{array}$ & $\begin{array}{r}-2.144^{\star \star \star} \\
(-5.00)\end{array}$ & $\begin{array}{r}-2.802^{\star * *} \\
(-4.31)\end{array}$ \\
\hline Central bank independence & $\begin{array}{r}1.096^{*} \\
(1.69)\end{array}$ & $\begin{array}{r}1.050^{*} \\
(1.75)\end{array}$ & $\begin{array}{r}.790 \\
(1.23)\end{array}$ & $\begin{array}{l}1.084^{*} \\
(1.80)\end{array}$ & $\begin{array}{r}3.873^{*} \\
(1.85)\end{array}$ \\
\hline Financial development & $\begin{array}{r}-.817^{\star \star \star} \\
(-3.21)\end{array}$ & $\begin{array}{r}-.814^{\star \star *} \\
(-3.14)\end{array}$ & $\begin{array}{c}-.971^{\star \star \star} \\
(-3.45)\end{array}$ & $\begin{array}{r}-1.083^{\star \star \star} \\
(-2.61)\end{array}$ & $\begin{array}{r}-.902^{* * *} \\
(-3.25)\end{array}$ \\
\hline Cyclical fiscal policy & $\begin{array}{l}.125 \\
(.44)\end{array}$ & $\begin{array}{r}.012 \\
(0.01)\end{array}$ & $\begin{array}{l}-.225 \\
(-.75)\end{array}$ & $\begin{array}{l}.166 \\
(.57)\end{array}$ & $\begin{array}{l}.099 \\
(.29)\end{array}$ \\
\hline Discretionary fiscal policy & $\begin{array}{r}.671^{\star \star \star} \\
(4.22)\end{array}$ & $\begin{array}{r}.659^{\star \star *} \\
(3.64)\end{array}$ & $\begin{array}{l}.322 \\
(.87)\end{array}$ & $\begin{array}{r}.650^{\star \star \star} \\
(4.15)\end{array}$ & $\begin{array}{r}.734^{\star \star \star} \\
(4.92)\end{array}$ \\
\hline Constant & $\begin{array}{r}-1.201 \\
(-1.31) \\
\end{array}$ & $\begin{array}{l}-1.037 \\
(-1.32) \\
\end{array}$ & $\begin{array}{l}-.063 \\
(-.06) \\
\end{array}$ & $\begin{array}{r}-.896 \\
(-1.24) \\
\end{array}$ & $\begin{array}{r}-3.070 * \\
(-1.86) \\
\end{array}$ \\
\hline Observations & 127 & 127 & 127 & 127 & 127 \\
\hline R-squared & .49 & .49 & .44 & .48 & .39 \\
\hline Wu-Hausman test (p-value) & .79 & .92 & .05 & .31 & .11 \\
\hline Hansen $\mathrm{J}$ test ( $p$-value) & .24 & .25 & .41 & .38 & .37 \\
\hline Weak identification (F-stat) & $27.76^{\star \star}$ & 3.40 & 7.65 & $24.41^{\star *}$ & 2.55 \\
\hline \multicolumn{6}{|l|}{ Exogeneity tests ( $p$-value): } \\
\hline Automatic stabilizers & $\ldots$ & .90 & .72 & .75 & .53 \\
\hline Central bank independence & .30 & .10 & .64 & .10 & $\ldots$ \\
\hline Financial development & .26 & .15 & .16 & $\ldots$ & .07 \\
\hline Discretionary fiscal policy & .13 & .07 & $\ldots$ & .34 & .26 \\
\hline Cyclical fiscal policy & .04 & $\ldots$ & .26 & .10 & .25 \\
\hline
\end{tabular}

Note: Robust t-statistics in parentheses. Time effects are not reported. Stars denote statistical significance at conventional levels ( ${ }^{\star}$ for 10 percent, ${ }^{* \star}$ for 5 percent, and ${ }^{\star \star \star}$ for 1 percent).

Two-stage least-squares estimates confirm the effectiveness of automatic stabilizers (column (1) of Table 3) and the stabilizing impact of financial development (column (4)), although the coefficient for the latter is somewhat higher 
in absolute value. The other results are difficult to interpret because instruments appear to be weak, which implies that the explanatory power of the excluded instruments in the first-stage regression is too low to provide reliable identification. Hence 2SLS estimators are biased and inefficient, especially in small samples such as ours (Stock, Wright and Yogo, 2002). It is nevertheless notable that our indicator of fiscal policy discretion does not appear to significantly raise volatility when it is instrumented. This could be a sign that this indicator also reflects other sources of output volatility not captured by the statistical model, but with potentially significant budgetary consequences (e.g., commodity or asset prices, exchange rates, inflation shocks...).

\section{Omitted variables}

The omission of relevant explanatory variables could also entail a correlation between the error term and the independent variables. We thus further examines the possibility of a bias by adding potential determinants of output volatility to the baseline specification. Keeping our focus on the effectiveness of automatic stabilizers, we followed Fatás and Mihov (2001) and selected controls likely to be correlated with both government size and output volatility. ${ }^{16}$ None of the added explanatory variable turns out being statistically significant (neither individually nor together, as shown in Table 4), and estimates of the coefficients of interest (automatic stabilizers, discretionary fiscal policy and financial development) are not statistically different across regressions.

In a panel context, a natural test for the robustness of our results to omitted variables is to add country fixed effects. The limited size of our sample confines our investigation to the parsimonious specifications in columns (8) and (9), which exclude the cyclical policy indicator because it has no timeseries variance. The stabilizing impact of financial development does not survive this "acid test," thus pointing to the possibility that some underlying, country-specific variables - perhaps "deep” institutional determinants ${ }^{17}$ jointly determine the level of financial development and macroeconomic volatility. In contrast, automatic stabilizers and discretionary policy still exhibit respectively stabilizing and destabilizing impacts on GDP growth. The interaction between $\mathrm{CBI}$ and discretionary fiscal policy passes the test

\footnotetext{
${ }^{16}$ These authors discuss in detail the motivation for each of these controls.

${ }^{17}$ See Acemoglu et al. (2002).
} 
as well, which adds support to the possibility that coordination failures in the policy mix could be a key channel through which fiscal discretion increases output volatility.

Table 4. Adding control variables

(Dependent variable: standard deviation of real GDP growth rate)

\begin{tabular}{|c|c|c|c|c|c|c|c|c|c|}
\hline & (1) & (2) & (3) & (4) & (5) & (6) & (7) & (8) & (9) \\
\hline Openness & $\begin{array}{l}.450 \\
(.66)\end{array}$ & $\begin{array}{r}.807 \\
(1.08)\end{array}$ & $\begin{array}{r}.862 \\
(1.21)\end{array}$ & $\begin{array}{r}.910 \\
(1.28)\end{array}$ & $\begin{array}{r}.923 \\
(1.30)\end{array}$ & $\begin{array}{r}.844 \\
(1.24)\end{array}$ & $\begin{array}{r}.881 \\
(1.34)\end{array}$ & $\begin{array}{l}-1.924 \\
(-0.91)\end{array}$ & $\begin{array}{l}-3.081 \\
(-1.31)\end{array}$ \\
\hline \multirow[t]{2}{*}{ Automatic stabilizers } & $-2.067^{\star \star \star}$ & $-2.428^{\star \star \star *}-$ & $2.574^{\star \star \star}$ & $2.439^{\star * *}$ & $2.426^{\star \star \star}$ & $-2.421^{\star \star \star}-$ & $2.326^{\star * *}$ & $2.867^{\star \star}$ & $-2.738^{* \star}$ \\
\hline & $(-4.94)$ & $(-5.14)$ & $(-4.60)$ & $(-4.37)$ & $(-4.47)$ & $(-4.17)$ & $(-3.93)$ & $(-2.48)$ & $(-2.56)$ \\
\hline \multirow{2}{*}{$\begin{array}{l}\text { Central bank } \\
\text { independence }\end{array}$} & $1.115^{\star}$ & $1.031^{*}$ & .984 & $1.065^{\star}$ & .885 & $1.382^{\star}$ & $-1.931^{*}$ & .423 & -1.689 \\
\hline & (1.85) & (1.69) & $(1.58)$ & $(1.67)$ & (1.33) & $(1.84)$ & $(-1.66)$ & $(.66)$ & $(-1.26)$ \\
\hline \multirow{2}{*}{$\begin{array}{l}\text { Financial } \\
\text { development }\end{array}$} & $-.782^{\star \star \star}$ & $-.820 * * *$ & $.920 * *$ & $-.874^{\star \star}$ & $-.914^{\star \star *}$ & $-.640^{\star \star}$ & $-.560^{\star}$ & .005 & .066 \\
\hline & $(-2.92)$ & $(-3.03)$ & $(-2.52)$ & $(-2.57)$ & $(-2.75)$ & $(-1.95)$ & $(-1.63)$ & $(.01)$ & $(.14$ \\
\hline Cyclical fiscal policy & $\begin{array}{l}.117 \\
(.39)\end{array}$ & $\begin{array}{r}.046 \\
(0.15)\end{array}$ & $\begin{array}{l}.013 \\
(.04)\end{array}$ & $\begin{array}{l}.039 \\
(.13)\end{array}$ & $\begin{array}{l}.051 \\
(.16)\end{array}$ & $\begin{array}{l}.126 \\
(.36)\end{array}$ & $\begin{array}{l}-.015 \\
(-.04)\end{array}$ & $\ldots$ & . \\
\hline Discretionary fiscal policy & $\begin{array}{r}.676^{\star \star *} \\
(4.65)\end{array}$ & $\begin{array}{r}.642^{\star \star \star} \\
(4.14)\end{array}$ & $\begin{array}{r}.639 \star \star \star \\
(4.17)\end{array}$ & $\begin{array}{r}.623^{\star \star \star} \\
(4.20)\end{array}$ & $\begin{array}{r}.711^{\star \star \star} \\
(4.55)\end{array}$ & $\begin{array}{r}.831^{\star \star *} \\
(5.32)\end{array}$ & $\begin{array}{l}-.187 \\
(-.49)\end{array}$ & $\begin{array}{r}.489 \star \star \star \\
(2.73)\end{array}$ & $\begin{array}{l}-.224 \\
(-.54)\end{array}$ \\
\hline \multirow[t]{2}{*}{$\begin{array}{l}\text { Country size } \\
\text { (log of GDP) }\end{array}$} & -.018 & -.007 & -.006 & -.008 & .004 & -.027 & -.033 & $\ldots$ & ... \\
\hline & $(-.28)$ & $(-.11)$ & $(-.09)$ & $(-.13)$ & $(.06)$ & $(-.44)$ & $(-.59)$ & & \\
\hline Mean real GDP growth & $\ldots$ & $\begin{array}{r}-.131 \\
(-1.44)\end{array}$ & $\begin{array}{r}-.132 \\
(-1.46)\end{array}$ & $\begin{array}{r}-.117 \\
(-1.21)\end{array}$ & $\begin{array}{r}-.113 \\
(.-1.22)\end{array}$ & $\begin{array}{l}-.081 \\
(-.83)\end{array}$ & $\begin{array}{r}-.105 \\
(-1.11)\end{array}$ & $\cdots$ & \\
\hline \multirow[t]{2}{*}{$\begin{array}{l}\text { GDP per capita } \\
\text { (PPP, } \\
\text { in log) }\end{array}$} & $\ldots$ & $\ldots$ & .075 & .077 & .118 & -.015 & .032 & $\ldots$ & \\
\hline & & & (.39) & $(.41)$ & $(.68)$ & $(-.08)$ & $(.17)$ & & \\
\hline Terms-of-trade volatility & $\ldots$ & $\ldots$ & $\ldots$ & $\begin{array}{l}.020 \\
(.96)\end{array}$ & $\begin{array}{r}.023 \\
(1.12)\end{array}$ & $\begin{array}{l}.015 \\
(.91)\end{array}$ & $\begin{array}{l}.010 \\
(.71)\end{array}$ & $\ldots$ & \\
\hline Oil dummy & $\ldots$ & $\cdots$ & $\ldots$ & $\ldots$ & $\begin{array}{l}-.844 \\
(-.98)\end{array}$ & $\begin{array}{l}-.792 \\
(-.85)\end{array}$ & $\begin{array}{l}-.385 \\
(-.46)\end{array}$ & $\cdots$ & \\
\hline Government stability & $\cdots$ & $\cdots$ & $\cdots$ & $\cdots$ & $\ldots$ & $\begin{array}{l}-.121 \\
(-.85)\end{array}$ & $\begin{array}{l}-.078 \\
(-.63)\end{array}$ & $\cdots$ & \\
\hline $\begin{array}{l}\text { Interaction: discretion } \mathrm{x} \\
\mathrm{CBI}\end{array}$ & $\ldots$ & $\ldots$ & $\ldots$ & $\cdots$ & $\ldots$ & $\ldots$ & $1.783^{\star * *}$ & $\ldots$ & $1.328^{* *}$ \\
\hline $\begin{array}{l}\text { Country-fixed effects (F- } \\
\text { test) }\end{array}$ & $\cdots$ & $\cdots$ & $\cdots$ & $\cdots$ & $\cdots$ & $\cdots$ & $\begin{array}{r}(2.63) \\
\cdots\end{array}$ & $2.94^{\star \star}$ & $\begin{array}{l}(2.11) \\
3.41^{\star *}\end{array}$ \\
\hline Constant & $\begin{array}{l}-.722 \\
(-.41) \\
\end{array}$ & $\begin{array}{l}-.852 \\
(-.48) \\
\end{array}$ & $\begin{array}{r}-1.666 \\
(-.64) \\
\end{array}$ & $\begin{array}{r}-1.722 \\
(-.65) \\
\end{array}$ & $\begin{array}{l}-2.432 \\
(-1.01) \\
\end{array}$ & $\begin{array}{l}-.571 \\
(-.22) \\
\end{array}$ & $\begin{array}{l}.854 \\
(.32) \\
\end{array}$ & $\begin{array}{r}-1.050 \\
(-.56) \\
\end{array}$ & $\begin{array}{l}.435 \\
(.21) \\
\end{array}$ \\
\hline Observations & 133 & 133 & 133 & 133 & 133 & 111 & 111 & 133 & 133 \\
\hline R-squared & .50 & .51 & .51 & .51 & .52 & .58 & .63 & .35 & .35 \\
\hline
\end{tabular}

Note: Robust t-statistics in parentheses. Time effects are not reported. Stars denote statistical significance at conventional levels ( ${ }^{\star}$ for 10 percent, ${ }^{* \star}$ for 5 percent, and ${ }^{* \star \star}$ for 1 percent). 


\subsection{Extensions}

We complete the analysis with two extensions. The first is to explore the determinants of private consumption volatility as the dependent variable, using specifications similar to (4). The other is to test whether automatic stabilizers moderated the growth collapse during the great recession of 2009.

\section{Fiscal policy and private consumption volatility}

While macroeconomic stabilization aims at reducing the volatility of output, welfare gains are often thought to be more closely associated with the stability of real private consumption. ${ }^{18}$ Although output and consumption (real growth) volatilities are strongly correlated (an unconditional correlation coefficient of 0.69 in our sample), the determinants of private consumption reflect individual choices that may be more directly responsive to opportunities to smooth consumption than to fiscal aggregates. Variance-decomposition exercises performed by Debrun, Pisani-Ferry and Sapir (2008) provide some support for that presumption, by showing that automatic stabilizers income tax payments and transfers - have not contributed to the decline in consumption volatility observed since the mid-1980s.

To model private consumption volatility, we follow equation (4). The results are qualitatively comparable to those found for output volatility, but with important nuances (Table 5). First, the stabilizing effect of financial development is quantitatively large and statistically significant, thereby confirming the important role of access to credit in providing consumption-smoothing opportunities to consumers. Second, automatic stabilizers continue to play a stabilizing role, although quantitatively smaller than for output (by roughly $1 / 2$ in most regressions) and less precisely estimated. Instrumenting government size yields quantitatively similar results to the output volatility equation. However, these results are not robust to the introduction of additional control variables, even though the latter remain non-significant. Third, the discretionary dimension of fiscal policy is generally destabilizing; but simultaneity concerns remain. Fourth, the cyclical dimension of fiscal policy now consistently has the expected negative impact on consumption volatility although large estimation

\footnotetext{
${ }^{18}$ The argument is not so clear-cut, however, because output fluctuations are likely to be more tightly related to employment, and thereby leisure.
} 
errors ${ }^{19}$ remain. Still, the contrast with the output equations is striking enough to suggest that systematic stabilizing actions by fiscal policymakers seem to be more effective at stabilizing private consumption, possibly because they are better targeted. Alternatively, this could suggest that our indicator of cyclical fiscal policy also captures automatic stabilizers on the expenditure side, which are by design targeted at smoothing individual consumer income. Finally, the interaction between the CBI index and our measure of the discretionary dimension of fiscal policy remains strong and statistically significant.

Table 5. Fiscal policy and consumption volatility

(Dependent variable: standard deviation of real GDP growth rate)

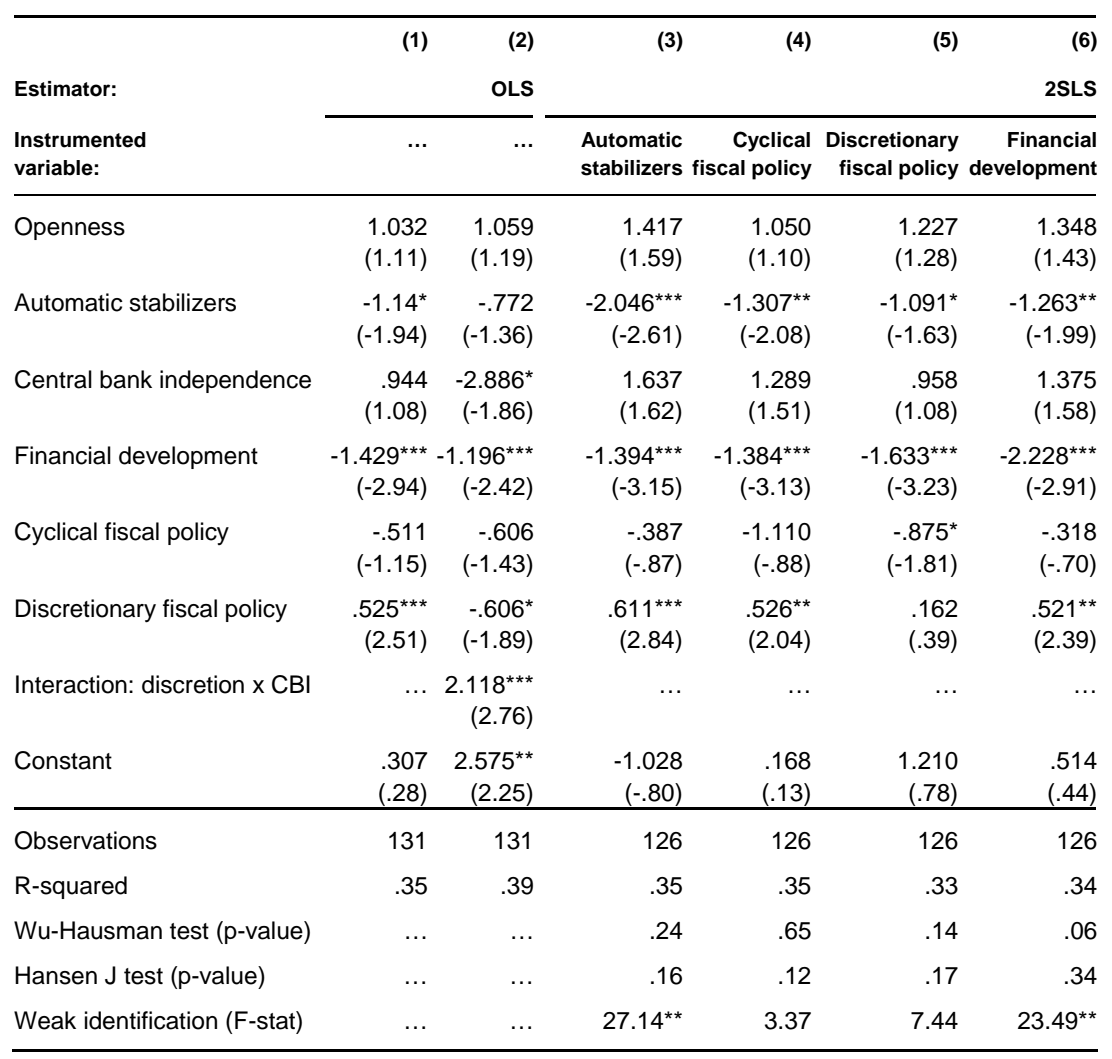

Note: Robust t-statistics in parentheses. Time effects are not reported. Stars denote statistical significance at conventional levels ( ${ }^{\star}$ for 10 percent, ${ }^{\star \star}$ for 5 percent, and ${ }^{\star \star \star}$ for 1 percent).

\footnotetext{
${ }^{19}$ Running the same regressions with the unrestricted indicator of cyclical policy indeed reduces $\hat{\phi}_{2}$ and increases errors.
} 
Automatic stabilizers during the crisis

With the effectiveness of monetary policy severely impaired by bankingsector weakness and the proximity of nominal policy rates to the zero bound, fiscal policy was summoned to play a major role in stabilizing the sharp contraction recorded in 2009. To assess the contribution of automatic stabilizers during this extreme episode, we introduced government size in a cross-country regression explaining the change in real GDP growth between 2008 and 2009 for a broad sample of advanced and emerging market economies. Control variables were selected along the lines of Mody (2010) and include the change in growth between 2007 and 2008, the output gap in 2007, real GDP growth in 2007, the current account balance in 2007, the change in the current account balance between 2007 and 2008, the real growth in bank credit to the private sector in 2007, the stock of bank credit to the private sector in 2007, the public debt-to-GDP ratio in 2007, trade flows to GDP in 2007 and dummy variables capturing sub-groups of countries (advanced EU, emerging EU, and emerging non-EU).

Table 5 shows that automatic stabilizers contributed to a more moderate fall in real GDP growth. Despite the financial nature of the initial shock, the degree of financial development also appears to have played a moderating role. These results are in line with the rest of our analysis. Interestingly, the level of public debt in 2007 - which could be interpreted as a proxy for the scope of maneuver with discretionary policy - does not emerge as a significant determinant of the growth collapse, although it has the expected negative sign. The other salient results are fairly intuitive. Specifically, economies subject to overheating (positive output gaps) and credit booms before the crisis were hit harder. The negative and statistically significant coefficients associated with the current-account variables show that the real shock was transmitted through trade channels, with countries dependent on external demand (i.e., with a large and growing current-account surplus) suffering more than others. 
Table 6. Automatic stabilizers during the great contraction of 2009 (dependent variable: change in real GDP growth between 2008 and 2009)

\begin{tabular}{|c|c|c|c|}
\hline & (1) & (2) & (3) \\
\hline Change in growth (2007-08) & $\begin{array}{r}-0.480 \\
(-1.638)\end{array}$ & $\begin{array}{r}-0.120 \\
(-0.425)\end{array}$ & $\begin{array}{r}-0.390 \\
(-1.379)\end{array}$ \\
\hline Output gap in 2007 & $\begin{array}{c}-0.395^{\star} \\
(-1.908)\end{array}$ & $\begin{array}{c}-0.440 * * \\
(-2.186)\end{array}$ & $\begin{array}{r}-0.614^{\star \star \star} \\
(-4.031)\end{array}$ \\
\hline Growth in 2007 & $\begin{array}{r}-0.217 \\
(-0.669)\end{array}$ & $\begin{array}{r}0.104 \\
(0.332)\end{array}$ & $\begin{array}{r}0.697^{\star * *} \\
(4.224)\end{array}$ \\
\hline Change in current account (2008-07) & & $\begin{array}{r}0.192 \\
(1.494)\end{array}$ & $\begin{array}{r}-0.299 * * * \\
(-2.897)\end{array}$ \\
\hline Current account in 2007 & & $\begin{array}{r}-0.039 \\
(-0.644)\end{array}$ & $\begin{array}{r}-0.174^{\star * \star} \\
(-3.309)\end{array}$ \\
\hline Real growth in credit to the private sector (2007) & & $\begin{array}{l}-0.120^{\star *} \\
(-2.502)\end{array}$ & $\begin{array}{r}-0.217^{\star \star \star} \\
(-4.755)\end{array}$ \\
\hline Automatic stabilizers & & & $\begin{array}{l}0.165^{\star *} \\
(2.274)\end{array}$ \\
\hline Public debt (2007) & & & $\begin{array}{r}-0.421 \\
(-0.434)\end{array}$ \\
\hline Stock of credit to the private sector (2007) & & & $\begin{array}{l}2.172^{\star \star} \\
(2.651)\end{array}$ \\
\hline Trade openness & & $\begin{array}{r}0.343 \\
(0.626)\end{array}$ & $\begin{array}{r}0.763^{*} \\
(1.860)\end{array}$ \\
\hline Advanced EU & $\begin{array}{r}-0.654 \\
(-0.876)\end{array}$ & $\begin{array}{r}-0.260 \\
(-0.296)\end{array}$ & $\begin{array}{r}-2.159 \\
(-1.639)\end{array}$ \\
\hline Emerging EU & $\begin{array}{l}-3.730 * \star \\
(-2.260)\end{array}$ & $\begin{array}{c}-3.477^{\star} \\
(-1.910)\end{array}$ & $\begin{array}{r}-1.474 \\
(-0.855)\end{array}$ \\
\hline Emerging non-EU & $\begin{array}{r}-0.885 \\
(-0.673)\end{array}$ & $\begin{array}{r}-0.537 \\
(-0.463)\end{array}$ & $\begin{array}{r}1.191 \\
(0.944)\end{array}$ \\
\hline \multicolumn{4}{|l|}{ Change in growth (2008-09) } \\
\hline Constant & $\begin{array}{r}-3.562^{\star \star \star} \\
(-3.219)\end{array}$ & $\begin{array}{c}-2.763^{\star \star} \\
(-2.630)\end{array}$ & $\begin{array}{r}-13.005^{\star \star \star} \\
(-3.308)\end{array}$ \\
\hline Observations & 46 & 46 & 39 \\
\hline R-squared & 0.342 & 0.502 & 0.782 \\
\hline
\end{tabular}

Note: Estimated by OLS with robust t-statistics in parentheses; with ${ }^{\star \star \star}$ designating statistical significance at the 1 percent threshold, ${ }^{*}$ at the 5 percent threshold and ${ }^{*}$ at the 10 percent threshold. The sample contains 46 advanced and emerging economies for which output gap data were available. Column (3) includes only 39 countries due to data constraints on credit to the private sector. Similar results are obtained with a robust estimator - taking into account the role of outliers. 


\section{Conclusions}

In this paper we have revisited the empirical link between fiscal policy and macroeconomic volatility (output and private consumption). Our analysis is based on a sample of 49 developing and advanced economies spanning the last 40 years. The results generally provide strong support for the view that fiscal stabilization operates mainly through automatic stabilizers. By contrast, fiscal policies systematically linked to cyclical conditions - be they pro- or counter-cyclical - do not appear to have a meaningful impact on output volatility. Moreover, fiscal variability not systematically related to the business cycle generally seems to increase output and consumption volatility, possibly due in part to conflicts with monetary authorities. However, these latter two results may suffer from a simultaneity bias because certain sources of budgetary volatility (e.g., exchange rate or inflation) are correlated with output volatility. Outside of fiscal policy, financial development seems to exert a moderating influence on income and, even more so, on consumption growth, but robustness analysis indicates that it may proxy the role of other country-specific features not included in our analysis. As regards monetary policy, central bank independence is associated with lower volatility, provided that the interaction between monetary and fiscal policies is taken into account.

The analysis contributes to the relevant literature in two ways. First, we show that the effectiveness of automatic stabilizers extends well beyond the narrow sample of 20 OECD countries explored by Fatás and Mihov (2001) and applies with equal strength to a broader set of highly heterogeneous countries, including developing economies. Second, our robustness tests strike a note of caution on the causal nature of the relationship between discretionary policy activism and output volatility (Fatás and Mihov, 2003).

Broader policy implications emerge. First, fiscal policy is unambiguously effective at durably stabilizing the economy when it operates in the same way as automatic stabilizers (in a timely, reasonably predictable and symmetric way). Second, governments could also contribute to macroeconomic stability by subjecting the pursuit of other objectives (redistribution or efficiency) to a "stability test." Our results indeed suggest that a conscious effort to reduce conflicts among public finance objectives and between monetary and fiscal policies could reduce output volatility. One practical way to do so 
is to subject budget preparation to quantitative objectives or even binding constraints defined in terms of a structural balance or expenditure ceilings.

That said, an exclusive reliance on automatic stabilizers as the channel of fiscal stabilization has limits and potential drawbacks. In terms of the limits, recent experience suggests that government revenues endogenously respond to asset price cycles not necessarily synchronized with the business cycle. The induced swings in commonly estimated structural budget balances may be difficult to sustain politically, thereby leading to pro-cyclical fiscal expansions when structural surpluses appear substantial (Alesina, 2000). In addition, automatic stabilizers may be insufficient in the case of acute crises, or when other policy instruments or consumption smoothing opportunities are constrained.

In terms of the drawbacks, the fact that large stabilizers come with large government sectors may adversely affect potential growth and an economy's resilience to shocks. As our analysis suggests, it could also increase the likelihood of destabilizing fiscal shocks. In light of these limits and drawbacks, a number of proposals to enhance fiscal stabilizers without increasing the size of government have been offered. For instance, given the difficulty of designing effective fiscal stimulus plans and the incomplete credibility of subsequent consolidations, automatic adjustments in selected tax rates or expenditure programs could be envisaged (see Baunsgaard and Symansky, 2009, for a survey and an assessment).

Looking forward, further research will need to address a number of pending issues. First, we see a need to explore more systematically the apparently strong impact of monetary-fiscal conflicts on macroeconomic volatility, as this could have important implications for the design of macro-fiscal frameworks. In particular, alternative measures of the quality of monetary policy should be envisaged. Second, we ignored the impact of expenditure and revenue composition on the size of fiscal stabilizers, possibly introducing measurement errors. Third, and related, more work is needed to improve measures of automatic stabilizers - particularly to have a better grasp of the role of expenditure composition - and of fiscal discretion. 


\section{References}

Acemoglu, D., Johnson, S., Robinson, J. and Thaicharoen, Y. (2002), Institutional causes, macroeconomic symptoms: Volatility, crisis and growth, manuscript, MIT, Cambridge, MA.

Afonso, A., Agnello, L. and Furceri, D. (2009), Fiscal policy responsiveness, persistence, and discretion, Public Choice, forthcoming.

Alesina, A. (2000), The political economy of the budget surplus in the US, Journal of Economic Perspectives 14, 3-19.

Andrés, J., Doménech, R. and Fatás, A. (2008), The stabilizing role of government size, Journal of Economic Dynamics and Control 32, 571-93.

Baunsgaard, T. and Symansky, S. (2009), Automatic fiscal stabilizers, IMF Staff Position Note 09/23, Washington, D.C.

Beck, T., Clarke, G., Groff, A., Keefer, P. and Walsh, P. (2001), New tools in comparative political economy: The database of political institutions, World Bank Economic Review 15, 165-76.

Blanchard, O. (2000), Commentary, Economic Policy Review, April, Federal Reserve Bank of New York, New York.

Blanchard, O. and Perotti, R. (2002), An empirical characterization of the dynamic effects of changes in government spending and taxes on output, Quarterly Journal of Economics 117, 609-57.

Blinder, A. and Solow, R. (1974), Analytical foundations of fiscal policy, in The Economics of Public Finance, The Brookings Institution, Washington, D.C.

Botman, D., Laxton, D., Muir, D. and Romanov, A. (2006), A new-open-economy macro model for fiscal policy evaluation, IMF Working Paper 06/45, Washington, D.C.

Crowe, C. and Meade, E. (2008), Central bank independence and transparency: evolution and effectiveness, IMF Working Paper 08/119, Washington, D.C.

Darby, J. and Mélitz, J. (2008), Social spending and automatic stabilizers in the OECD, Economic Policy 56, 715-56.

Debrun, X. and Kapoor, R. (2010), Fiscal policy and macroeconomic stability: Automatic stabilizers work, always and everywhere, IMF Working Paper 10/111, Washington, D.C.

Debrun, X., Pisani-Ferry, J. and Sapir, A. (2008), Should we forsake automatic stabilization?, European Economy - Economic Papers 316, Brussels.

Dolls, M., Fuest, C. and Peichl, A. (2009), Automatic stabilizers and economic crisis, CESifo Working Paper 2878, Munich.

Fatás, A. and Mihov, I. (2001), Government size and automatic stabilizers: International and intranational evidence, Journal of International Economics 55, 3-28.

Fatás, A. and Mihov, I. (2003), The case for restricting fiscal policy discretion, Quarterly Journal of Economics 118, 1419-47.

Fatás, A. and Mihov, I. (2009), The euro and fiscal policy, NBER Working Paper 14722.

Fedelino, A., Ivanova, A. and Horton, M. (2009), Computing cyclically-adjusted balances and automatic stabilizers, IMF Technical Notes and Manuals 09/05, Washington, D.C. 
Furceri, D. (2009), Stabilization effects of social spending: Empirical evidence from a panel of OECD Countries, North American Journal and Economics and Finance 21, 34-48.

Galì, J. (1994), Government size and macroeconomic stability, European Economic Review 38, 117-132.

Galì, J. and Perotti, R. (2003), Fiscal policy and monetary integration in Europe, Economic Policy 18, 533-72.

Henisz, W. (2006), The Political Constraint Index Dataset, Wharton School of the University of Pennsylvania, Philadelphia.

Horton, M., Kumar, M. and Mauro P. (2009), The state of public finances: A crosscountry fiscal monitor, IMF Staff Position Note 09/21, Washington, D.C.

Kumhof, M. and Laxton, D. (2009), Chile’s structural surplus rule: A model-based evaluation, IMF Working Paper 09/88, Washington, D.C.

Lee, Y. and Sung, T. (2007), Fiscal policy, business cycles and economic stabilization: Evidence from industrialised and developing countries, Fiscal Studies 28, 437-62.

Martinez-Mongay, C. and Sekkat, K. (2005), Progressive taxation, macroeconomic stabilization and efficiency in Europe, European Economy - Economic Papers 233, Brussels.

Mody, A. (2010), Who fell in 2009? Those with current account deficits or with extra froth? (http://www.voxeu.org/index.php?q=node/4507).

Mohanty, M.S. and Zampolli, F. (2009), Government size and macroeconomic stability, BIS Quarterly Review December, 55-68.

Perotti, R. (2005), Estimating the effects of fiscal policy in OECD countries, Proceedings, Federal Reserve Bank of San Francisco.

Rodrik, D. (1998), Why do more open economies have bigger governments?, Journal of Political Economy 106, 997-1032.

Romer, C. and Romer, D. (2008), The macroeconomic effects of tax changes: Estimates based on a new measures of fiscal shocks, University of California, Berkeley, (elsa.berkeley.edu/ cromer/draft1108.pdf).

Silgoner, M.-A., Reitschuler, G. and Crespo-Cuaresma, J. (2003), Assessing the smoothing impact of automatic stabilizers: Evidence from Europe, in G. TumpelGugerell and P. Mooslechner (eds.), Structural Challenges for Europe, Edward Elgar, Cheltenham.

Spilimbergo, A., Symansky, S., Blanchard, O. and Cottarelli, C. (2008), Fiscal policy for the crisis, IMF Staff Position Note 08/01, Washington, D.C.

van den Noord, P. (2002), Automatic stabilizers in the 1990s and beyond, in M. Buti, J. von Hagen and C. Martinez-Mongay (eds.), The Behavior of Fiscal Authorities Stabilization, Growth and Institutions, Palgrave, Basingstoke.

van der Ploeg, R. (2005), Back to Keynes?, CESifo Economic Studies 51, 777-822.

Virén, M. (2005), Government size and output volatility: Is there a relationship? Bank of Finland Discussion Papers 8, Helsinki.

Wyplosz, C. (2006), European monetary union: The dark sides of a major success, Economic Policy 21, 207-61. 


\section{Appendix}

\section{Data sources}

Data on government size (general government expenditure as a percentage of GDP), GDP per capita, openness to trade, public debt (percentage of GDP), private consumption, dependency ratio and urbanization rates are obtained from the IMF World Economic Outlook Database. Financial development, which is captured by the total stock of credit by deposit money banks to the private sector as a percentage of GDP, and indices of oil prices are obtained from the IMF International Financial Statistics. Data on political and electoral systems are from the Database of Political Institutions (Beck et al., 2001). The political constraint index is from the POLCON database (Henisz, 2006). The index of government stability is from the International Country Risk Guide database. The index of Central Bank Independence is from Crowe and Meade (2008).

\section{Automatic stabilizers, fiscal multipliers and $\hat{\phi}_{1}$}

It is useful to illustrate the link between our estimates of the impact of automatic stabilizers and conventional measures of fiscal policy effectiveness. For simplicity, the starting point is a log-linear, backward-looking IS equation:

$$
y=\lambda y_{-1}+\gamma_{0} d-\gamma_{1}\left(i-\pi^{e}\right)-\gamma_{2}\left(e+\pi-\pi^{*}\right)+\gamma_{3} y^{*}+\varepsilon
$$

with $0<\lambda<1$ and $\gamma_{0}, \ldots ., \gamma_{3}>0$, where the output gap ${ }^{21} \gamma$ depends on the government budget deficit $d$, the real interest rate, the real exchange rate, external demand, and a random disturbance (all with obvious notations). The decomposition between the cyclical and the cyclically adjusted deficit $\left(d^{s}\right)$ can be written as $d=d^{S}-\alpha \gamma$, where $\alpha>0$ denotes the sensitivity of the budget deficit to the output gap. The cyclically adjusted deficit itself reflects the cyclical policy and a residual:

$$
d^{S}=-\beta y+\mu
$$

\footnotetext{
${ }^{21}$ A similar relationship can be assumed to hold for the log of output.
} 
, with $\beta>0$. Hence, $d=-(\alpha+\beta) y+\mu$. Substituting for the budget deficit, we can write the long-run relationship $\left(y=y_{-1}\right)$ as follows:

$$
y=\frac{1}{\left(1+\gamma_{0}(\alpha+\beta)-\lambda\right)}\left[\gamma_{0} \mu-\gamma_{1}\left(i-\pi^{e}\right)-\gamma_{2}\left(e+\pi-\pi^{*}\right)+\gamma_{3} y^{*}+\varepsilon\right] .
$$

Clearly, greater automatic stabilizers, a more countercyclical discretionary fiscal policy and a greater fiscal multiplier all contribute to offset IS shocks:

$$
\begin{aligned}
& \frac{\partial y^{2}}{\partial \varepsilon \partial \alpha}=\frac{\partial y^{2}}{\partial \varepsilon \partial \beta}=\frac{-\gamma_{0}}{\left(1+\gamma_{0}(\alpha+\beta)-\lambda\right)^{2}}<0, \\
& \frac{\partial y^{2}}{\partial \varepsilon \partial \gamma_{0}}=\frac{-(\alpha+\beta)}{\left(1+\gamma_{0}(\alpha+\beta)-\lambda\right)^{2}}<0 .
\end{aligned}
$$

To illustrate how these fiscal policy parameters are related to the estimated impact of automatic stabilizers on output volatility in the empirical model, let us write the variance of the output gap as: ${ }^{22}$

$$
\operatorname{var}(y)=\left(\frac{1}{1+\gamma_{0}(\alpha+\beta)-\lambda}\right)^{2} \operatorname{var}(\xi),
$$

with $\xi=\left[\gamma_{0} \mu-\gamma_{1}\left(i-\pi^{e}\right)-\gamma_{2}\left(e+\pi-\pi^{*}\right)+\gamma_{3} y^{*}+\varepsilon\right]$.

This implies:

$$
\frac{\partial S d(y)}{\partial \alpha}=\frac{-\gamma_{0}}{\left(1+\gamma_{0}(\alpha+\beta)-\lambda\right)^{2}} S d(\xi)<0,
$$

and

\footnotetext{
${ }^{22}$ The same expression applies to the first difference of the output gap.
} 


$$
\frac{\partial S d(y)^{2}}{\partial^{2} \alpha}=\frac{2 \gamma_{0}^{2}}{\left(1+\gamma_{0}(\alpha+\beta)-\lambda\right)^{3}} S d(\xi)>0 .
$$

Stronger automatic stabilizers thus reduce the standard deviation of the output gap, but at a decreasing rate because stabilizers themselves run against the potency of exogenous fiscal impulses. This second-round effect likely explains why using the logarithm of government size (instead of its level) generally yields better statistical results. The link between $\hat{\phi}_{1}$ and the fiscal policy parameters can be written as:

$$
\phi_{1}=\frac{\partial S d(y)}{\partial \log (\alpha)}=\frac{\partial S d(y)}{\frac{1}{\alpha} \partial \alpha}=\frac{-\alpha \gamma_{0}}{\left(1+\gamma_{0}(\alpha+\beta)-\lambda\right)^{2}} S d(\xi)
$$

Using equation (A3), we can determine a range of values for $\hat{\phi}_{1}$ consistent with plausible calibration of the various parameters. As $\operatorname{Sd}(\xi)$ is not observable, we simply assume - in line with recent empirical estimates ${ }^{23}$ - that fiscal policy can stabilize about one third of shocks to $\xi$. We thus set $S d(\xi)$ equal to 1.5 times the measure of output variability in our sample. Assuming $^{24}$ that $\lambda=0.6$, that $\gamma_{0}$ spans over $[0.1 ; 1.5]$ and that government size can be anywhere between 0.2 and 0.6 , the implied values for $\hat{\phi}_{1}$ lie between -2.64 and -0.48 . We can also use equation (A3) to calculate, for given government size, the range of values of fiscal policy multipliers implicit in our estimates of $\hat{\phi}_{1}$. Taking the sample average of government size of 0.38 and assuming that discretionary fiscal policy is acyclical $(\beta=0)$, the 95 percent confidence interval of $\hat{\phi}_{1}$ (i.e., [-2.81;-1.22]) $)^{25}$ maps into "fiscal multipliers" $\left(\left(\gamma_{0}\right)\left(1+\gamma_{0}(\alpha+\beta)-\lambda\right)^{-1}\right)$ between 0.4 and 1.5. Replicating this exercise for the 95 percent confidence interval of $\hat{\phi}_{1}$ using the

\footnotetext{
${ }^{23}$ For recent evidence, see Dolls, Fuest and Peichl (2009).

${ }^{24}$ The value for the persistence parameter was set on the basis of the average value obtained in straightforward OLS estimations of equation (A1) for a variety of advanced countries in our sample.

${ }^{25}$ This refers to regression (3) in Table 2 of the main text.
} 
standard deviation of the output gap as the measure of volatility (i.e. [-2.29;0.92]), we obtain somewhat lower multipliers (between 0.4 and 1.0). 


\title{
Fiscal sustainability in the wake of the financial crisis*
}

\author{
Torben M. Andersen **
}

\begin{abstract}
Summary
The financial crisis affects public finances significantly, and adds to fiscal sustainability problems caused by future demographic changes. This paper discusses the problems in formulating an exit strategy for fiscal policy, focusing on the situation for the Nordic countries. Outset is taken in analyses of fiscal sustainability and it is examined to what extent they constitute a benchmark for formulating a consolidation/exit strategy for fiscal policy. Short-run stabilization concerns may be in conflict with the need to consolidate public finances. It is discussed to what extent such a dilemma exists due to expectations effects, persistence in employment and the specific policy changes undertaken to ensure fiscal sustainability. Fiscal policy targets and frameworks in the Nordic countries are also considered.
\end{abstract}

Keywords: Fiscal policy, sustainability, smoothing, fiscal norms JEL Classification Numbers: E61, E62, H60.

* Paper presented at the Nordic Economic Policy Review conference on Fiscal Consequences of the Crisis, Copenhagen, March 2010. I thank participants and Steinar Holden for constructive comments and Tyra Ekhagen, Christina Enegren, Anders Møller Jørgensen and Lauri Taro for provision of data, and Peter Stephensen and Marianne Frank Hansen for output from a simulation on the DREAM model.

** School of Economics and Management, Aarhus University, CEPR, CESifo and IZA. 
The financial crisis has significantly affected public finances both due to the direct effects running via automatic stabilizers and discrete policy initiatives and due to reassessments of underlying budget positions. The swing in public finances is extraordinary; in 2007 the EU average budget deficit was 0.8 percent of GDP, and for both 2009 and 2010 it is projected to be around 7 percent of GDP. The average government debt-to-GDP ratio is expected to increase from 60 percent to 90 percent over the same period. Moreover, the risk profile in many countries seems to be biased in a negative direction.

This significant deterioration in public finances comes on top of fiscal sustainability problems already present before the crisis due to approaching demographic changes; see e.g., European Commission (2006, 2009a). The financial crisis has reinforced this agenda and made policy adjustments more acute and larger, but also more difficult since they are to be implemented under unfavorable economic conditions. The debate on fiscal policy is thus tense and often phrased as a need to formulate an exit strategy. That is, after having pursued an expansionary policy to counteract the effects of the crisis, there is now a need to focus more on medium- to long-run aspects which, in turn, require a consolidation of public finances. The trade-off between the short-run and medium/long-run effects of fiscal policy is thus at stake. This is not only an issue of ensuring that crisis measures are phased out to ensure that they are temporary, the need for additional policy initiatives and reforms to ensure fiscal sustainability are equally important.

The urge for policy initiatives can be underpinned in different ways. One is a fear of repeating the problems experienced in the 1970s and 1980s of prolonged periods with high and persistent unemployment and high debt levels. For decades this has been constraining economic policy, and is thus not a recipe for replication. Another is the adverse expectations effects arising from failure to address the problem, which can induce adverse financial market responses and thus reinforce the crisis and accelerate debt accumulation. In addition the problem of fiscal sustainability raises issues in relation to intergenerational distribution and risk sharing. The question then is how initial debt problems as well as the projected demographic changes and their implications for public finances should be addressed.

The aim of this paper is to examine how the crisis has affected fiscal sustainability and the implied need for policy responses. An important recent advance in economic policy planning is more systematic efforts to evaluate fiscal sustainability. However, the commonly adopted approach leaves some 
ambiguities and has some pitfalls in relation to policy implications. It is discussed whether the different elements underlying a given fiscal sustainability problem call for the same policy responses. The policy implications are considered and related to the problem of fiscal sustainability. The paper does not cover the case where countries face an acute solvency problem.

The difficulty in formulating an exit strategy arises due to a possible trade-off between short-run concerns for stabilization and medium/long-run concerns for fiscal sustainability. An important question is how steep this trade-off is. This obviously depends on the nature of the crisis (persistence) but also on the design of policy. Three factors are particularly important. First, there is a question of how strongly the short- and long-run effects are linked via expectations channels, and the extent to which this may mute the contractionary effects of consolidation efforts. Second, persistence in responses to shocks worsens the public finance implications of shocks, but this may also imply that a short-term fiscal stimulus is not necessarily in conflict with fiscal sustainability if it can successfully counteract persistence. Third, is it possible to reap a double dividend in the sense that some of the structural reforms, like retirement and pension reforms which are needed to address fiscal sustainability problems, also can work to support aggregate demand in the short run?

This paper addresses these issues against the background of the experience of the Nordic countries, and the paper is organized as follows. Section 1 clarifies how the financial crisis has affected public finances, and illustrates the orders of magnitude involved in consolidating public finances and ensuring fiscal sustainability. Section 2 considers the concept of fiscal sustainability and the extent to which the standard sustainability indicator can be translated into a policy prescription. The trade-off between short-run and medium-run considerations is discussed in Section 3. Section 4 focuses on aspects in designing a fiscal policy framework to ensure a credible exit strategy. Section 5 gives a few concluding remarks.

\section{The crisis and public finances}

The swing in public finances due to the financial crisis is extraordinarily large. Figure 1 shows the change in primary balance between 2007 and 2009, when almost all OECD countries experienced a large change causing 
substantial deficits. A noteworthy aspect is that this has been accompanied by a radical change in the structural primary budget balance. Although such measures are associated with numerous conceptual and measurement problems, it is a strong indication that the crisis is not perceived only as an unusual negative temporary shock, but as something which has induced a structural change and thus a fundamental reassessment of public finances.

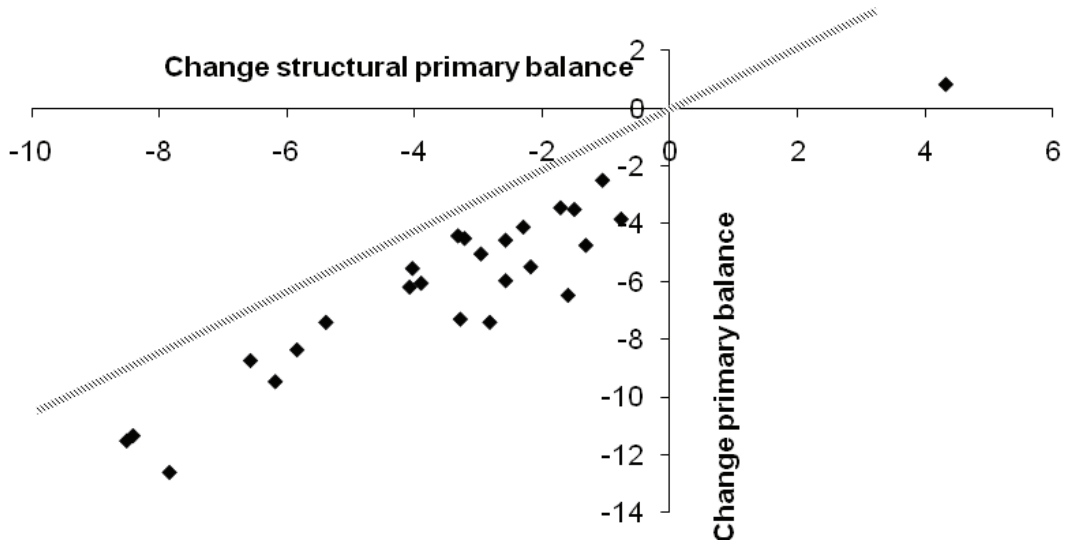

Figure 1. Change in primary budget balance, 2007-2009, selected OECD countries Source: OECD, Economic Outlook database, www.sourceoecd.org

The orders of magnitude underlying the current debate on the need for fiscal consolidation is captured by Table 1 . In the first column, it shows the change in the debt ratio caused by the crisis, measured as the difference between the debt ratio projected for 2011 by the OECD and its value in 2008. For illustrative purposes, the table interprets this change in two extreme ways, as a temporary change only affecting the economies over the period 2008-2011 and as a permanent change. The second column gives the effect of the crisis on fiscal sustainability when the shock is interpreted as temporary and financed over an infinite future. From this perspective the needed adjustment is rather modest, amounting to 0.2 percent of GDP in a number of countries, and in no case more than 0.65 percent of GDP. The last column shows the order of adjustment if the debt increase should be financed over a five-year period, in which case the changes amount to 3-4 percent of GDP. 


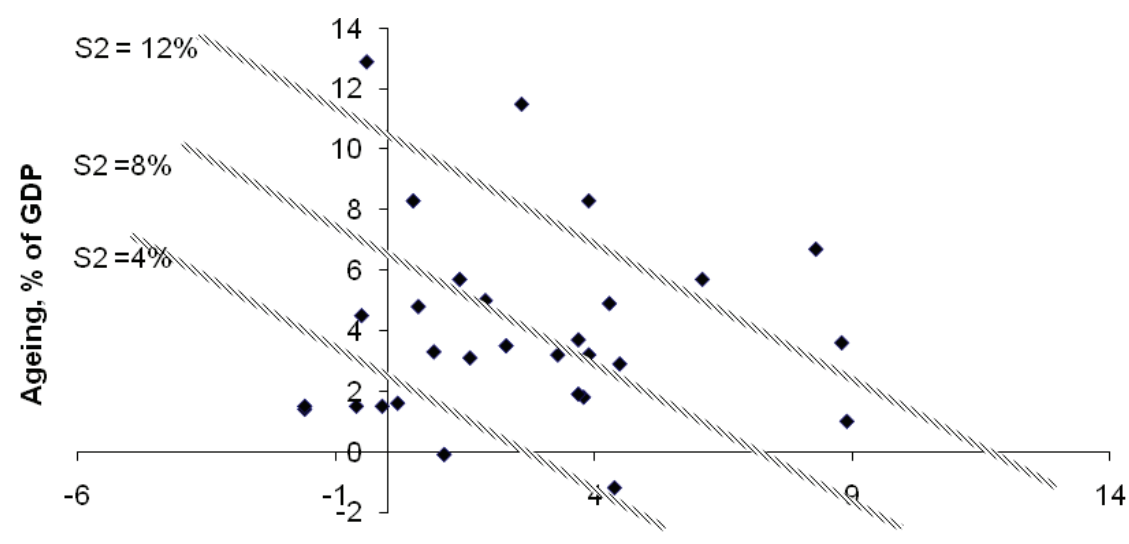

Initial budget situation, $\%$ of GDP

Figure 2. Sustainability indicator for EU countries - decomposed into effect of demographic changes and initial situation

Source: European Commission (2009a).

Note: The initial budget situation refers to the part of the sustainability problem which is attributed to the initial debt level and budget position, and ageing refers to effects on sustainability of the consequences of demographic shifts.

These changes come on top of the already identified fiscal sustainability problems mainly arising from demographic shifts. Figure 2 gives the result from a recent assessment of fiscal sustainability for the EU countries where the sustainability metric (see below) is split into a part caused by demographics and another part caused by the initial situation and the crisis. A number of countries face adjustment problems corresponding to permanent budget improvements in the order of 4-8 percent of GDP, and in some cases as much as $10-12$ percent. 


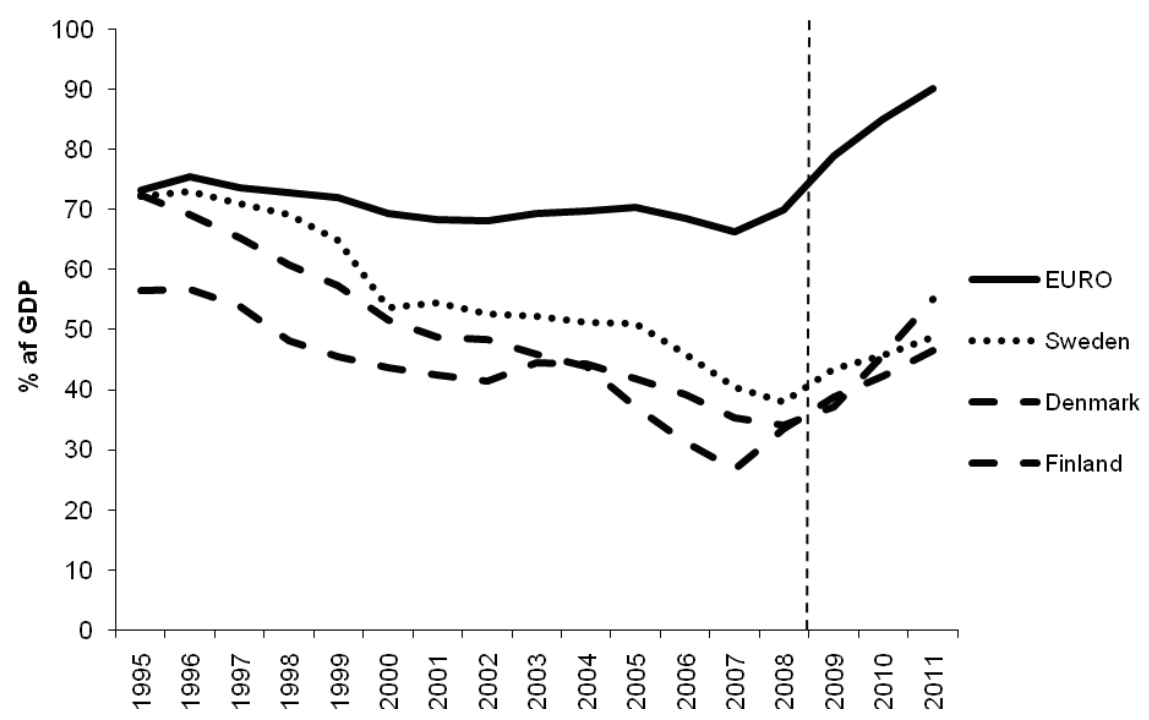

Figure 3. Public debt - Maastricht definition, EURO area and Nordic countries Source: OECD, Economic Outlook database, www.sourceoecd.org

Note: Values for 2009-2010 are projections. Data are not available for Norway and Iceland.

One reason why the public finance implications of the crisis are so dramatic is failure to consolidate public finances before the crisis. The less countries have been able to consolidate, the more exposed they are to the adverse effects of the crisis. It is striking that debt consolidation prior to the crisis was very modest; cf. Figure 3. Various explanations can be given for this fact, but failure to consolidate severely constrains the degrees of freedom in economic policy for a number of countries. Interestingly, the Nordic area stands out as countries where there was a significant consolidation prior to the crisis; that is, countries with large public sectors and thus strong automatic stabilizers were able to consolidate their public finances so as to make better room for accommodation of bad shocks. 
Table 1. Debt effects of the crisis and needed adjustments

\begin{tabular}{|c|c|c|c|}
\hline & \multirow{2}{*}{$\begin{array}{r}\text { Change in debt ratio } \\
2008-2011 \text { a) }\end{array}$} & \multicolumn{2}{|c|}{ Change in sustainability indicator b) } \\
\hline & & $\begin{array}{r}\text { Permanent } \\
\text { financing }\end{array}$ & $\begin{array}{r}\text { Financing } \\
\text { over a five } \\
\text { year period }\end{array}$ \\
\hline Austria & 16.1 & 0.24 & 3.38 \\
\hline Belgium & 14.9 & 0.22 & 3.12 \\
\hline Czech Republic & 19.1 & 0.28 & 3.99 \\
\hline Germany & 16.5 & 0.24 & 3.46 \\
\hline Denmark & 13.0 & 0.19 & 2.71 \\
\hline Spain & 27.2 & 0.40 & 5.69 \\
\hline Finland & 21.0 & 0.31 & 4.38 \\
\hline France & 23.3 & 0.35 & 4.88 \\
\hline United Kingdom & 37.2 & 0.55 & 7.77 \\
\hline Greece & 27.6 & 0.41 & 5.78 \\
\hline Hungary & 14.1 & 0.21 & 2.94 \\
\hline Ireland & 43.8 & 0.65 & 9.16 \\
\hline Italy & 15.1 & 0.22 & 3.16 \\
\hline Luxembourg & 14.9 & 0.22 & 3.12 \\
\hline Netherlands & 15.7 & 0.23 & 3.28 \\
\hline Poland & 12.0 & 0.18 & 2.50 \\
\hline Portugal & 21.9 & 0.32 & 4.58 \\
\hline Slovak Republic & 16.7 & 0.25 & 3.50 \\
\hline Sweden & 10.8 & 0.16 & 2.26 \\
\hline
\end{tabular}

Source: Own calculations based on data from OECD Economic Outlook 86, www.sourceoecd.org.

Notes: a) Change in Maastricht debt from 2008 to 2011. b) Change in sustainability indicator to finance this higher debt level, growth corrected real rate of interest is 0.015 . c) Needed improvement in budget balance over a five-year period to neutralize the debt increase. ${ }^{1}$

${ }^{1}$ If the change in debt is denoted by $\Delta \mathrm{D}$ and the budget improvement over the five year horizon by $\Delta \mathrm{b}$, then

$$
\Delta b \sum_{i=0}^{4}\left(\frac{1}{1+r}\right)^{i}=(1+r) \Delta D \text { and hence } \Delta b=(1+r) \frac{1-\left(\frac{1}{1+r}\right)}{1-\left(\frac{1}{1+r}\right)^{5}} \Delta D
$$




\section{Fiscal sustainability}

A major improvement in fiscal policy planning in recent years is the explicit use of assessments of fiscal sustainability. This is exemplified by the fact that such assessments are an integral part of the stability and convergence program submitted annually by EU member countries and the publication of the EU report on fiscal sustainability in member countries (European Commission, 2009a). Other countries also make assessments of fiscal sustainability. Assessing fiscal sustainability is a planning tool to evaluate the consequences of current policies against the background of projected future changes in society. Changing demographics is an obvious example.

The most commonly used indicator gives the permanent improvement in the primary budget needed to ensure that the intertemporal budget constraint for the public sector is fulfilled; see Andersen and Pedersen (2006) and European Commission (2006). In the EU terminology, this is known as the S2 indicator. ${ }^{2}$ While an important tool, it is important to be aware of the properties of this metric and, in particular, its shortcomings when inferring policy implications from the metric.

\subsection{Sustainability indicator}

To define the sustainability indicator, denote by $b_{t}$ the primary budget balance (revenues less expenditures) measured relative to GDP and by $r$ the growth-corrected real rate of return (for simplicity assumed constant). The debt level (measured relative to GDP) at the end of period $t$ is denoted $d_{t}$ and hence $d_{t}=(1+r) d_{t-1}-b_{t}$.

The indicator for sustainability of fiscal policy (s) is defined ${ }^{3}$ as the permanent improvement in the budget balance relative to GDP which given the initial debt level $\left(d_{t-1}\right)$, the projected primary budget balances $\left(E_{t} b_{t+i}, i \geq 0\right)$ and the growth-corrected real rate of interest (r) ensures that the intertempo-

\footnotetext{
${ }^{2}$ The alternative (S1) is the requirement to ensure a debt level of 60 percent of GDP in 2050 (now 2060). While such a finite-horizon approach may appear more appealing to policy makers, it is problematic since the results are very sensitive to the imposed end-point condition, and there is no clear theoretical rationale to guide the choice of end-point conditions. Moreover, assessments can change from one year to the next when the planning period is changed.

${ }^{3}$ This is the indicator termed S2 by the European Commission; see e.g., European Commission (2006).
} 
ral budget constraint is fulfilled. The sustainability indicator $s$ is thus defined as the solution to

$E_{t}\left[\sum_{i=0}^{\infty}\left(\frac{1}{1+r}\right)^{i} b_{t+i}\right]+\sum_{i=0}^{\infty}\left(\frac{1}{1+r}\right)^{i} s_{t}=(1+r) d_{t-1}$

where $E_{t}$ denotes the expectations operator conditional on period $t$ information. The indicator $\mathrm{s}_{\mathrm{t}}$ thus gives the estimate of the permanent change in the primary budget balance to ensure that the intertemporal budget constraint is met based on period $t$ information. If $s_{t}>0$, there is a sustainability problem since the primary budget balance must be permanently improved to ensure that the intertemporal budget constraint is met. The sustainability indicator is thus defined so as to ensure that the present value of all future net revenues (left-hand side of (1)) at the end of period t equals the end-of-period t value of the initial debt (right-hand side of (1)).

The sustainability indicator can also be written as a weighted average of all future primary budget balances and the initial debt level transformed into an infinite annuity, i.e.

$$
s_{t}=-\sum_{i=0}^{\infty} v_{i} E_{t} b_{t+i}+\frac{r}{1+r} d_{t}
$$

Where

$$
v_{i}=\frac{r}{1+r}\left(\frac{1}{1+r}\right)^{i} \text {, and } \sum_{i=0}^{\infty} v_{i}=1
$$

As shown in Appendix A.1, the sustainability indicator computed at two adjacent periods in time, $t$ and $t+1$, is related as

$$
S_{t+1}=[1+r] S_{t}+\frac{r}{1+r}\left[E_{t} b_{t+1}-b_{t+1}\right]+\frac{r}{1+r} \Psi_{t+1}
$$

\section{Where}




$$
\Psi_{t+1} \equiv\left[\sum_{i=1}^{\infty}\left(\frac{1}{1+r}\right)^{i+1}\left[E_{t+1} b_{t+i+1}-E_{t} b_{t+i+1}\right]\right]
$$

In interpreting (2), note first that in the absence of policy initiatives, the sustainability indicator grows by $r$ between two adjacent periods for the simple reason that postponing policy adjustments calls for larger changes. Next, the period $t+1$ indicator differs from the period $t$ indicator due to new information (shocks). This has two components. The first is the unanticipated change in the period $t+1$ budget balance. If it turns out to be better than anticipated, $\left(E_{t} b_{t+1}<b_{t+1}\right)$, the sustainability indicator falls by this amount, multiplied by the infinite annuity factor $r /(1+r)$, which determines how a given value is translated into an infinite annuity, and vice versa. The second factor captured by the term $\Psi_{t+1}$ summarizes the reassessment of the entire future due to new information between period $t$ and $t+1$. It is given as a present value and hence transformed into an infinite annuity via $r /(1+r)$.

This source of change is important in practice since the estimation of the future path of the structural budget balance is associated with considerable uncertainty. The methods for assessing the structural budget balance usually rely on a rather aggregate approach, and the assessments are often revised significantly. It is noteworthy that the structural balance in practice follows the actual balance rather closely in ex post evaluations. These problems create an important source of uncertainty and the dilemma that sustainability indicators can be revised significantly within short periods of time, which, in turn, makes it difficult to base policy recommendations on firm interpretations of the indicator.

The sustainability indicator is basically a "smoother" since it transfers given budget profiles in combination with the initial net-debt level into an infinite annuity, expressing the needed change in the primary budget balance to meet the intertemporal budget constraint. Therefore the infinite annuity factor $r /(1+r)$ is crucial (see also below). However, under reasonable assumptions this is a rather small number (for $r=0.01, r /(1+r)=0.0099$ and for $r=0.02$, $r /(1+r)=0.0196)$ implying that we should expect only small changes in the sustainability indicator between periods unless there is a significant reassessment of the future budget path. In the case of an unanticipated change in the period t primary balance for an unchanged future path, the sustainability indicator will barely be affected $\left(\frac{\partial s}{\partial\left(E_{t} b_{t+1}-b_{t+1}\right)}=\frac{r}{1+r} \cong 0\right)$ since the 
change is spread over an infinite future. In the case of a permanent change in the assessment of the primary budget, the sustainability indicator changes proportionally (if $E_{t+1} b_{t+i+1}-E_{t} b_{t+i+1}=p$ for all $i$, we have $\partial s / \partial p=1$ ) since a permanent change cannot be diversified.

While there are obvious communication advantages from summarizing a sustainability assessment in one number, it also has several drawbacks which may confuse the policy debate. The essential output from a sustainability analysis is the path for the primary balance. Does it display any systematic tendencies? If so, why and when? A fundamental issue is that sustainability analyses have to consider a far future ${ }^{4}$, but this does not necessarily imply that current policies should be fine-tuning conditions several decades into the future. This is not the point of including sustainability analysis in the formulation of fiscal policies. The purpose is to identify systematic tendencies and correct them well in advance due to long adjustment and announcement lags.

To illustrate this point, consider the profile for the primary budget balance for the Nordic countries; cf. figure 5 . The sustainability indicators as computed by the respective ministries of finance are 1.3 for Denmark, 0.6 for Sweden and 4 for Finland. No sustainability indicator is computed for Norway, but a generational account shows that there is a need for an adjustment amounting to 10.5 percent of mainland GDP. The fiscal sustainability problems are substantial for both Norway and Finland. The comparison between Denmark and Sweden is particularly interesting. Both countries currently have crisis-induced deficits, but the profile hereafter differs. Denmark will have deficits for several decades but eventual surpluses in the latter half of the century. For Sweden it is the opposite; surpluses will eventually turn into systematic deficits. The sustainability indicators are roughly the same for Denmark and Sweden, ${ }^{5}$ but it is rather obvious that the optimal policy response is hardly the same. This leaves the important lesson that an assessment of needed policy changes cannot be made solely from the S2

\footnotetext{
${ }^{4}$ The alternative of working with a fixed horizon is associated with several problems. One is that such analyses are extremely sensitive to the particular end-point imposed. This introduces an arbitrariness into the analysis which is particularly problematic in microfounded models. Second, this end-year will have to be changed from time to time, which, in turn, can cause large changes in the assessment that may be difficult to communicate.

${ }^{5}$ For Denmark it was assessed to be 0.8 and for Sweden 0.6. In the recent convergence reports, the indicator has been changed to 1.3 for Denmark, but there has been no revision for Sweden; see Ministry of Finance - Denmark (2010) and Ministry of Finance - Sweden (2010).
} 
indicator. The implied profile for the primary budget balance must be considered. This also has the advantage that it is less sensitive to the chosen discount rate.

\subsection{Smoothing arguments}

The way the sustainability indicator is computed implies that it implicitly shares a given adjustment burden equally (as a percent of GDP) across an infinite future and thus current and future generations. This serves an important positive purpose in clarifying whether there is a need for policy changes, but it cannot automatically be given a normative interpretation as to how policies should be changed.

Much of the policy debate in relation to sustainability analyses takes outset in Barro's (1979) tax smoothing argument that tax rates should be kept constant over time to minimize tax distortions, allowing the budget to absorb variations in net expenditures. Temporary expenditure variations would be absorbed via the budget, while permanent expenditure changes require a permanent change in the tax rate. A straightforward implication from having identified a sustainability problem is to endorse a "savings" strategy, which requires a consolidation of public finances to cope with future (net) expenditure increases due to ageing. The S2 indicator immediately gives the needed consolidation. That is, by consolidating public finances prior to the netexpenditure drift, one can ensure that the intertemporal budget constraint is met. However, such a general policy inference cannot be made independently of the underlying reasons for a sustainability problem since issues of both intergenerational risk-sharing and distribution are involved; see Andersen (2009). A case in point is the fact that an important factor behind the changing demographic structure is an increase in longevity, and it is not obvious that current generations should contribute to the financing of the consequences of future generations enjoying longer longevity. Hence, the policy implications to be inferred from a given sustainability problem depend on their underlying causes, and it is useful to distinguish between initial conditions, shocks and trends.

Taking the fact that public debt redistributes across generations leads to an alternative interpretation of sustainability in terms of risk diversification across time and thus generations. Via the public budget, current generations can diversify the consequences of risk with future generations. The change 
in the sustainability indicator gives the permanent contributions to be made for this arrangement to work. For such risk diversification to be justified, the shock should be exogenous and temporary in nature. Hence, if the financial crisis is interpreted as an outside event, there is an argument for risk diversification, whereas if it is taken to be a result of current generations undertaking too large risks in the hope of high returns, there is no argument for risk diversification. In the same vein, risk diversification presumes symmetry between favorable and unfavorable states of nature. Based on this view, the policy implications to be inferred from a given sustainability problem depend on the causes underlying the initial situation, the elements of risk sharing involved, and a question of possible trends in the budget balance.

\section{Initial conditions}

The initial condition for the assessment of fiscal sustainability is the net debt position, which summarizes the consequences from the past of relevance for the future as concerns public finances. It may be argued that the public net debt level is the key variable affecting future generations. Future generations may want to take different decisions than current generations, and it is not obvious that the latter should constrain this possibility. Bygones are bygones, and therefore the relevant part of the past of importance for future decision making is the debt level, i.e., "leaving all future generations with the same options as current generations”. Logically this reasoning would require that a broader approach is taken to evaluate the net-assets left for future generations. This is an important issue, but beyond the purpose of an analysis of fiscal sustainability.

Whether the initial debt level should be subsumed into problems to be diversified over time is an open question. These issues are complicated by the fact that there is no well-defined debt level or target. Fiscal sustainability is consistent with an infinity of debt levels since any debt level translates into a requirement for debt servicing which affects the sustainability indicator. The initial debt level may be interpreted as being the accumulated consequences of past failures to adjust policies. If so, the initial debt level should be coped with by current generations and not in part transferred to future generations. If the debt level accumulates past shocks to be diversified over time, there is reason to take a smoothing perspective, as further discussed below. 
Denmark

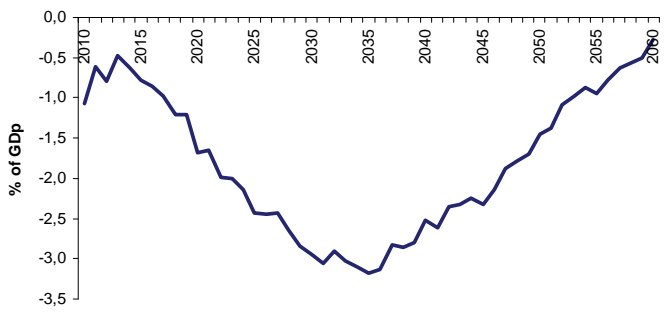

Norway

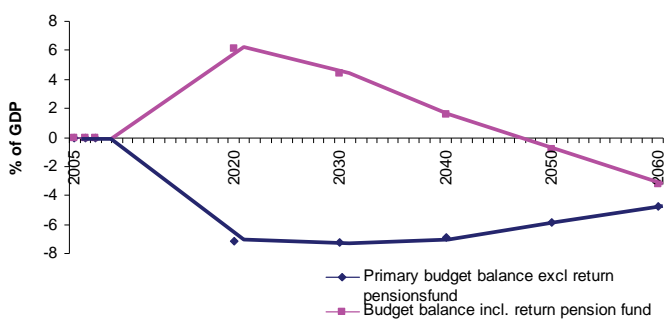

Finland

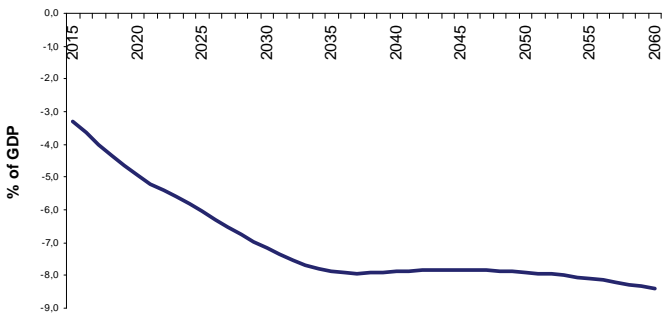

Sweden

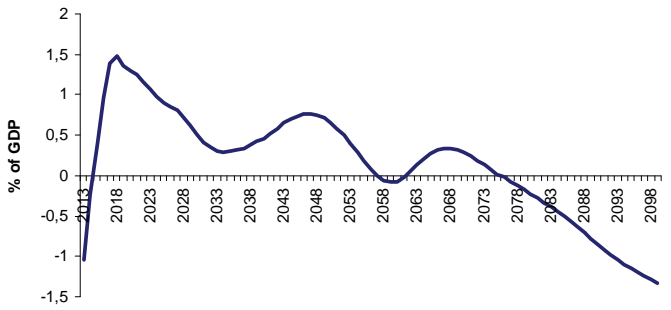

Figure 4. Profiles for the projected primary budget balance, Nordic countries

Source: Data supplied from the respective ministries of finance based on the following publications: Ministry of Finance Denmark (2010), Ministry of Finance Norway (2009a,b), Ministry of Finance Sweden (2010) and Ministry of Finance Finland (2010).

Note: a) The data are based on Perspektivmeldingen 2009. In Nasjonalbusjettet for 2010 revised figures show a more pessimistic projection.

\section{Insurance}

It is well established that the public budget can offer risk diversification across time and thus generations, and on terms which private markets cannot; see e.g., Gordon and Varian (1988). There is a very close relationship between the sustainability indicator and basic insurance or risk diversification arguments. Basic risk diversification arguments imply that consumption is adjusted to a temporary income change by the infinite annuity factor $(r / 1+r)$ and one-toone to permanent changes in income (see Appendix A.2). Hence, as concerns shocks affecting public finances, the sustainability indicator translates this into a needed budget change in precisely the same way as basic risk diversification theory would diversify the shock. To put it differently, the 
effect of shocks on the sustainability indicator gives the requirements to diversify these shocks over an infinite period. ${ }^{6}$

In theory there are good arguments for letting the public balance serve this insurance function which is basically embedded in automatic stabilizers. If we think of business cycles as driven by exogenous shocks propagated by internal adjustment mechanisms, there is a strong smoothing argument for using the public budget as a buffer (the basic rationale for stabilization policy). It turns out, however, that this buffer or smoothing function under realistic assumptions can be served with small consequences for fiscal sustainability. This is illustrated in Figure 5 showing the effect of a 1 percent change in GDP on the fiscal sustainability indicator for different levels of

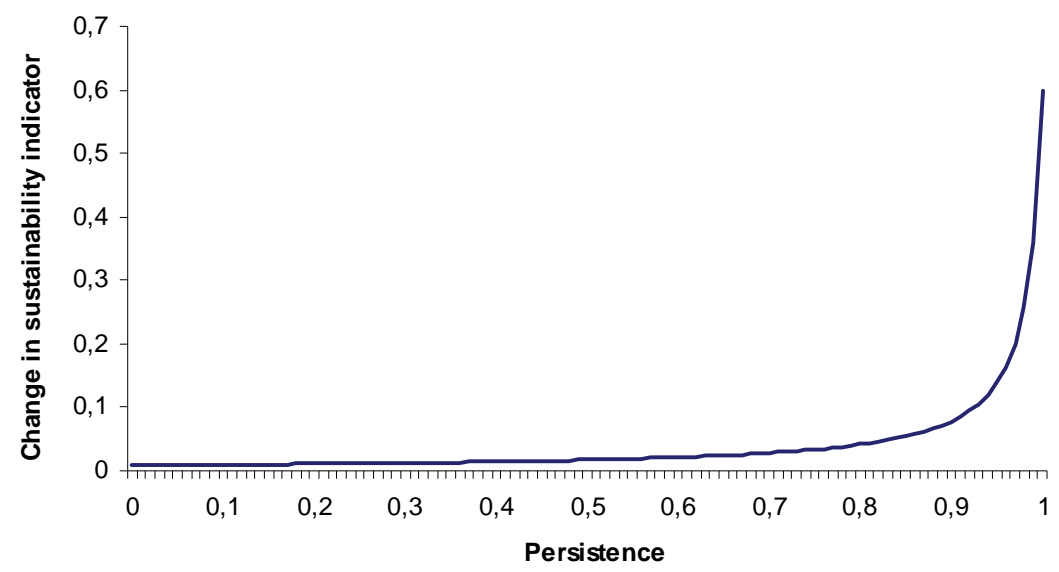

Figure 5. Shocks and the sustainability indicator: Effect of a $1 \%$ drop in GDP depending on persistence in adjustment

Source: Own calculations based on formula in footnote 7 for $r=0.015$ and $\beta=0.6$.

\footnotetext{
${ }^{6}$ This may also provide an argument for some precautionary savings; see van der Ploeg (2008).
} 
persistence in the adjustment process. ${ }^{7}$ The figure is drawn for strong automatic stabilizers (strong budget sensitivity to GDP: 0.6). The financial crisis has produced output losses in the order of 5 percent of GDP (GDP gap); cf. OECD (2009b) and IMF (2009). As seen from Figure 5, even such a large shock does not have very substantial effects on fiscal sustainability since the change in the fiscal sustainability indicator is in the order of 0.02 to 0.1 (see also Table 1). Whether seen from one or the other perspective, the consequences are moderate. This shows that even a large shock has only moderate effects for the fiscal sustainability indicator, even when allowing for persistence. In short, risk diversification can only account for rather modest changes in the fiscal sustainability indicator, and this points to the fact that the current situation includes causes which obviously should not be diversified over time.

There is a political economy or moral hazard side to this insurance mechanism. For it to operate, it has to be symmetric; that is, "good" periods should be reflected in larger surpluses for "bad" periods to justify larger deficits. It may be questioned whether this condition is met since ex ante to the crisis in the booming years, there was only very moderate consolidation in most countries; cf. Figure 3. In addition, it may be argued that to the extent that the crisis is induced by excessive risk taking on the part of current generations in the anticipation that an intergenerational risk-sharing device would diversify the shock, there is clearly an argument for restricting intergenerational risk sharing. If the crisis is due to "overborrowing and overspending”, there is a no-bail-out argument for a quick "repayment” - "current generations causing the crisis should also pay for it".

An implication of the above is that to the extent that the crisis has led to a significantly different assessment of potential output, structural unemployment, etc., and therefore of the structural budget balance, then this calls for an immediate change in budget policies. Such structural changes are not to be diversified over time.

\footnotetext{
${ }^{7}$ Let output measured in deviations from long-run levels (y) follow the process $y_{t}=\rho y_{t-1}+e_{1} ; t \geq 1,0<\rho<1$ where $e_{1}$ is a shock appearing in period, $1\left(y_{0}=0\right)$. Hence, $y_{\mathrm{t}+\mathrm{j}}=p^{j} e_{1} j \geq$ 1 , i.e., adjustment is here assumed to be generated by a sluggish adjustment process. Denote the budget sensitivity to output variations by $\alpha$ implying that budget variations are given as $\Delta b_{\mathrm{t}}=\alpha y_{t}$. The effect of the shock on the sustainability indicator is therefore$$
\Delta s=-\frac{r}{1+r} \sum_{j=0}^{\infty}(1 /(1+r)) \rho^{j} \alpha e_{1}=-\frac{r \alpha e_{1}}{1+r-\rho}
$$ 


\section{Trends}

Sustainability problems are to a large extent driven by underlying trends, of which changing demographics is an important contributory factor. A noteworthy driver of these changes is increasing longevity (healthy ageing), and for this component it is highly questionable whether it should be addressed by pre-funding or savings. Increasing longevity is a welfare improvement, and the reason it creates financial problems is that some future generations enjoy the increase in longevity, while retirement ages do not necessarily follow. At the same time, various entitlements for services provided by the public sector are used more. This shifts the balance between the years contributing to and benefiting from the scheme and causes an upward drift in net expenditures; see Andersen (2009). It is not clear why current generations should be contributing to the financing of this. The proper adjustment is to change entitlements (e.g., retirement age or pensions) such that the problem is solved. Pragmatically, this can be phrased in the way that the systematic tendency towards deficits - the trend - should be taken out by structural reforms.

Sustainability analyses take outset in current policies and ask whether they are sustainable. In many respects this may be considered a conservative assumption since demands and needs for publicly provided services and transfers may change over time. A particular issue is the role of relative price increases driven by differences in productivity between services and other goods (Baumol's disease) and the fact that certain services like health care plausibly have a demand with a high income elasticity (Wagner's law). In addition, improvements in health care and treatment may create new demands. Various analyses of these issues show that sustainability problems can easily increase significantly; see e.g., DREAM (2009). From a policy perspective, it is very important to perform such analyses to prepare for the needed prioritization and to inform the general public as to what the public sector can be expected to accomplish in terms of service provision. Such analyses are useful in identifying trends which policy makers will have to address, but since they are mainly driven by the fact that future generations are richer and have better options than current generations, it is not obvious that these issues should affect the formulation of short-term budget policies and consolidation targets. 


\subsection{Policy implications}

Assessment of fiscal sustainability is an important platform for economic policy planning. While the sustainability indicator is a useful summary metric, it is important to consider the underlying budget profile. This is needed to clarify the causes and the time profile of the problem, both of which are important for the appropriate policy response. The sustainability indicator has as its premise that financial balances should be diversified over time. There are, however, a number of cases where this is not justified. In most countries public finances display strong trends, and this is generally an indication of underlying problems which are not appropriately addressed by a funding or savings strategy. Rather, structural reforms are required to remove the trend. One may also pragmatically say that if there is no trend within the next 20-25 years, then there is no immediate need for policy initiatives. Problems arising in the future require consideration and planning, but not necessarily pre-funding. The pragmatic answer is thus that the primary budget should tend to fluctuate around a structural budget balance close to zero.

The changes in public finances caused by the crisis are not all to be diversified over an infinite future, and a consolidation over a relatively short horizon should therefore be undertaken, so as to bring public finances into a better position. This is supported by an intergenerational distribution argument and a precautionary argument in the sense of creating room for maneuver in handling possible future crises.

\section{Exit strategies - tensions between short-run and medium-run objectives}

Having identified a need for a consolidation of public finances, the next question is how and when. That is, how is an exit made from current expansionary fiscal policies to a consolidation which is likely to have short-run contractionary effects. This raises difficult questions on how to make policy changes contingent on the business cycle situation. It may also be argued that too late is better than too early since the costs of not timing the intervention correctly are asymmetric because the current recovery is fragile (see e.g., IMF, 2009). A key issue is the steepness of the trade-off between a short-run concern for activity vs a medium/long-run concern for fiscal sus- 
tainability, and especially the extent to which it depends on the specific consolidation measures undertaken. This section addresses three main aspects which are important for this trade-off, namely expectations, persistence, and whether all structural reforms necessarily are contractionary in the short run.

\subsection{Expectations effects}

Expectations link the future to the current, and therefore expectations formation may be of crucial importance for the trade-off between short-run and medium-run considerations. Two aspects have been discussed in the literature, namely the role of expectations concerning a possible future failure to meet debt obligations and how expectations concerning needed future policy changes may fit into the current situation.

\section{Interest rate effects}

A path with an increasing debt ratio is unsustainable and may therefore cause expectations of debt failures, which, in turn, will affect interest rates. This leads directly to further debt accumulation via more costly debt servicing, but it also has contractionary effects which may worsen problems.

The interest rate effect may be both a "country-specific" effect and a "general-equilibrium" effect. The country-specific effect relates to the possibility that the premium on bonds issued by a given state increases compared to other state bonds (as has happened during this crisis for e.g., Greece and Italy); for an analysis see e.g., Baloss et al. (2009). This is driven by the debt default possibility. The relation between such risk premia and the debt level is usually found to be highly non-linear in the sense that when debt levels exceed certain levels, there are steep increases in the risk premium. Bi and Leeper (2010) consider the possibility of debt default from the perspective of the ability to tax; that is, distortionary effects of taxation set an upper limit to taxation (the top point of the Laffer curve). Hence, the higher the initial tax level, the closer to the limit and the higher, ceteris paribus, the default risk. Based on calibrations for Sweden, they find that the relation between default premia in interest rates and the debt level is highly non-linear. The effect is marginal until a critical debt level (80 percent to 100 percent of GDP) at which there is a steep increase in the premium. Interestingly, in a recent empirical study Reinhart and Rogoff (2010) find that the effect of public 
debt on GDP growth is weak for debt rates below 90 percent of GDP. Hence, for a "normal" debt level the default risk premium is not an important issue.

An additional aspect concerning interest rate effects arises via differences in the exchange rate regime. In particular, the Danish case with a pegged exchange rate stands out. The credibility of the exchange rate peg is crucial, and this depends critically on fiscal policy since this is the main macroeconomic instrument available for bringing economic development on a path consistent with the exchange rate peg. In this sense there is an additional expectations effect to be taken into account in fiscal policy.

The general equilibrium effect arises via the interest rate response of global capital markets if many governments simultaneously issue more debt. It is an open question whether this is an externality or just an efficient market response to changes in the desire of states/governments to engage in intertemporal substitution. At any rate, such interest rate increases will affect the budget and tend to accelerate debt accumulation. ${ }^{8}$

\section{Aggregate demand effects}

Temporary fiscal expansions induce less crowding out than permanent changes or, phrased differently, they have larger multipliers. This is a rather robust finding which holds in a wide class of models (see Andersen, 2005) and is also supported by empirical work. European Commission (2009b) reports various fiscal multipliers and finds that the multipliers for temporary changes are in general $2-3$ times larger than for permanent changes. This underlines the importance of ensuring that the crisis measures are genuinely temporary since this enhances the expansionary effects and reduces the consequences for fiscal sustainability.

The problem faced by most countries is that a fiscal sustainability problem is present on top of the difficulties created by the crisis. There has been some discussion whether fiscal multipliers could be reversed by expectations effects; that is, can a fiscal contraction be expansionary? If so, there is no

\footnotetext{
${ }^{8}$ In passing, note that to the extent that interest rates are increasing and this is taken into account in assessments of fiscal sustainability, it is possible that this may work in the direction of reducing the sustainability problem, other things being equal. This is so if the underlying budget profile exhibits a systematic tendency towards deterioration. Since the sustainability assessment is based on the present value of this budget profile, it follows that future deficits matter less if the interest rate is higher.
} 
conflict between short-run concerns for activity and medium-term concerns for fiscal sustainability. While this is a theoretical possibility, it is a possibility which only arises under very special circumstances; see e.g., Andersen (2005), and the empirical evidence in support of this possibility is unclear; see e.g., Giudice et al. (2003). However, even though the reversal of the sign of fiscal multipliers is an unlikely event, it remains that the underlying effect can be at play and work to mute the multiplier effects. The reason is that unsolved fiscal sustainability problems fuel expectations about future policy changes to address the problem (e.g., tax increases or spending cuts), which in turn affects aggregate demand via changes in private consumption and investment directly and indirectly via interest rate effects.

This raises the question whether the formulation of a credible exit strategy on how to address the sustainability problem may actually make fiscal stimulus packages more effective by supporting private consumption and investment directly and possibly indirectly via interest rate effects. Theoretical models support this conclusion since forward-looking agents will discount future policy changes needed to solve the sustainability problem, and the more adjustment is delayed, the stronger this may mute the current impact of policies. In Corsetti et al. (2009), it is shown that the fiscal multiplier of an increase in public consumption increases when it is accompanied by a credible spending reversal; that is, the increase in public consumption is later to be followed by a decrease in public consumption so as to stabilize the debt level. This arises both via the fact that a large policy change is needed, but possibly also via uncertainty about future policies. These findings stress the importance of a clear announcement of an exit strategy to provide an anchor for expectations formation.

\subsection{Unemployment persistence}

A crucial question is whether increases in unemployment induced by the crisis will turn persistent and cause a long-lasting decline in the employment rate. Such a development has severe social costs, but will also be of crucial importance to public finances. Public finances are very sensitive to the employment rate, in particular in the Nordic countries due to an extended welfare state implying high tax burdens on labor and a generous social safety net. In quantitative terms, a decline in the employment rate by 1 percentage point in Denmark will worsen the budget balance (in percent of GDP) by 0.8 
percentage points. The quantitative importance is about the same in the four large Nordic countries. This is another way of expressing the well-known large automatic budget effects found in the Nordic countries; see Girouard and André (2006).

Past experience also underlines the importance of persistent declines in employment for public finances. Figure 6 gives the development in the employment rate after the last deep crisis in the Nordic countries in the late 1980s and early 1990s, and the considerable persistence in the decline is directly observable in the figure. It is also seen that it has been difficult to reach the same employment levels again. These drops in the employment rate were all associated with significant public finance problems. It is noteworthy that recent assessments of the situation in the Nordic countries take the position that there is no significant persistency effect of the crisis.

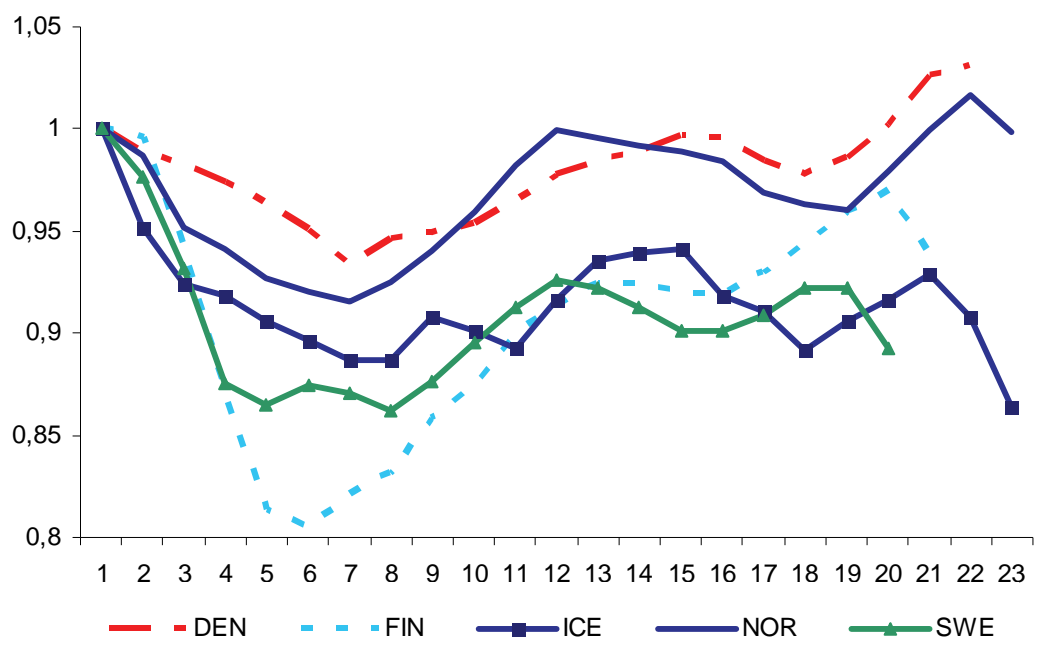

Figure 6. The employment rate in past crises in the Nordic countries.

Source: Computations based on data from www.source.oecd.org

Note: The figure shows the employment rate in subsequent years relative to its peak level in the 1980s. The peak year is 1987 for Denmark, 1990 for Sweden, 1987 for Norway, 1987 for Iceland and 1989 for Finland. The employment rate is civilian employment as a percent of the population aged 15-64.

Hence, it is critical for public finances whether the current crisis produces a persistent decline in the employment rate. Persistency in employment rates depends both on the nature and duration of shocks, labor market institutions, 
and policy. The issue of employment persistence is thus important for fiscal policy through two channels. First, it implies a systematic tendency toward budget deteriorations, creating a need for corrective measures, but second, it also affects the need for fiscal policy intervention in the first place.

If a decrease in employment via various persistence mechanisms generates a prolonged fall in employment, this may strengthen the case for an active stabilization policy. If the policy can successfully reduce the effect of the shock, it may follow that the quantitative implications of persistence are reduced since fewer are affected by unemployment and thus exposed to the risk of transit into long-term unemployment. This raises the question whether a fiscal expansion motivated by the crisis necessarily worsens the fiscal sustainability problem. A negative shock with persistent effects will under a passive policy have a prolonged adverse effect on public finances via automatic budget responses. A short-run expansionary fiscal policy will - if appropriately designed - reduce the negative output and employment effects of the shock. Hence, although the policy intervention worsens public finances on impact, it may improve them in a medium-term perspective by reducing the quantitative role of persistence on the employment level and thus public finances. The more effective the policy instrument (relative to its immediate budget costs) and the stronger the automatic budget responses or endogenous persistence, the more likely this is the case (see Appendix A.3).

A simple quantitative assessment of this question is given in Table 1 using OECD measures for automatic budget responses and a standard measure of output persistence. The table considers the minimum level for the fiscal multiplier ensuring that a fiscal stimulus improves fiscal sustainability via its effect on the quantitative importance of persistence. The stimulus is assumed to be marginal and credible as a temporary change. The table can be read as giving the country-specific minimum level of the multiplier for which there is no tension between short- and long-run considerations. Alternatively, it provides information on how the critical multiplier level depends on the underlying budget sensitivity and the persistence. 
Table 2. Critical multiplier level for a temporary fiscal stimulus to improve fiscal sustainability

\begin{tabular}{lrcr}
\hline & $\begin{array}{r}\text { Automatic budget } \\
\text { reaction }\end{array}$ & Persistence output gap & $\begin{array}{r}\text { Critical multiplier } \\
\text { level }\end{array}$ \\
\hline Denmark & 0.59 & 0.49 & 0.88 \\
Finland & 0.48 & 0.67 & 0.71 \\
Iceland & 0.37 & 0.57 & 1.20 \\
Norway & 0.53 & 0.64 & 0.71 \\
Sweden & 0.55 & 0.65 & 0.67 \\
\hline
\end{tabular}

Source: Own calculations based on data from www.sourceoecd.org

Note: Calculated on the basis of the formula derived in Appendix A.3. The metric for the automatic budget reaction is the semi-elasticities reported in Giruard and André (2005), and the persistence is measured by the correlation of the output gap. The critical multiplier level gives the minimum level of the output effects of a change in fiscal policy equal to 1 percent of GDP for a temporary fiscal stimulus to improve fiscal sustainability. The calculations assume $r=0.02$.

It is seen that rather large multiplier effects are required if short-run stabilization also is to contribute to improve fiscal sustainability. The critical multiplier level exceeds the multiplier effects usually assumed in policy discussions. As an example, the European Commission (2009) reports various fiscal multipliers, and only for public investments are the multipliers of an order of magnitude matching the critical multiplier level. Note that this illustration may underestimate the critical multiplier since all persistence in output gaps is attributed to endogenous mechanisms, while in the data part of the persistence is shock driven. Note, however, that even if multiplier effects do not reach the critical level, it is an implication that the sustainability consequences of fiscal expansions are counteracted by the extent to which it serves to reduce persistence.

This quantitative illustration may leave the impression that a strong automatic budget reaction or persistence in output (employment) adjustment implies that there is no conflict between short-run and long-run considerations. However, this conclusion overlooks the fact that the same two conditions imply that the effect of exogenous shocks on public finances is more severe and therefore adds to fiscal sustainability problems (cf. above). Hence, it is not correct to infer that a difficult choice between short-run and long-run considerations disappears.

While there are good reasons to pursue an active fiscal stabilization policy to counteract the effects of the crisis, it is questionable whether it is a policy which is well targeted to address the problems of persistence in unemployment. This is so due to labor market dynamics and heterogeneity. Two dimensions are particularly important. First, the sectors adversely af- 
fected by the crisis (building sector, financial sector, export sector) are not necessarily those which would benefit from a more expansionary policy increasing public and/or private demand. Hence, the perceived effect of fiscal stimulus on aggregate demand may underestimate the implied need for labor mobility and adjustment. In short, the areas experiencing job creation are not necessarily the same as those suffering from crisis induced job destruction. Second, labor market responses to business cycles are unbalanced, which, in particular, tends to affect the young, the old, the less skilled, immigrants and other marginal groups in the labor market.

It is well known that unemployment for the young is strongly countercyclical, and there is therefore a concern that youth unemployment may be a source of persistence. However, the fact that a particular group is more cyclically sensitive to unemployment does not necessarily imply that this group is more exposed to long-term unemployment and hence persistent drops in employment rates. This is illustrated below by following different cohorts and their employment rate over age and hence time.

The overall pattern between age and employment rate is an inverse Ushape; that is, employment rates are low as young, reach a peak as middleaged, and decline towards normal retirement ages. The interesting issue is whether there is any clear cohort persistence involved. That is, does the labor market performance of the middle-aged depend on the labor market prospects when they were young and, similarly, how does the labor market performance of the old depend on labor market prospects when middle-aged. For illustration, define the young to be the age group 20-24, the middle-aged the age group 40-44, and the old the age group 60-64. Figure 7 gives the employment rates at various age groups for different cohorts in the case of Sweden for young and old, respectively. The pattern for the young is rather erratic. Some cohorts have experienced low/high employment in their younger days, but this does not have a clear relationship to their performance as middle-aged. That is, cohorts who entered the labor market with a lower (higher) employment rate compared to other cohorts do not maintain a relatively low (high) employment rate. For the elderly the pattern is more clear since cohorts having low (high) employment rates in their late 40s also tend to have low (high) employment rates in their 60s. Hence, while it is unclear whether there is any persistence among the young, there is indication of some persistence effects for older workers in the case of Sweden. This does not identify any sources of persistence, but suggests that they may arise for 
(a) Cohort specific employment rates - the young

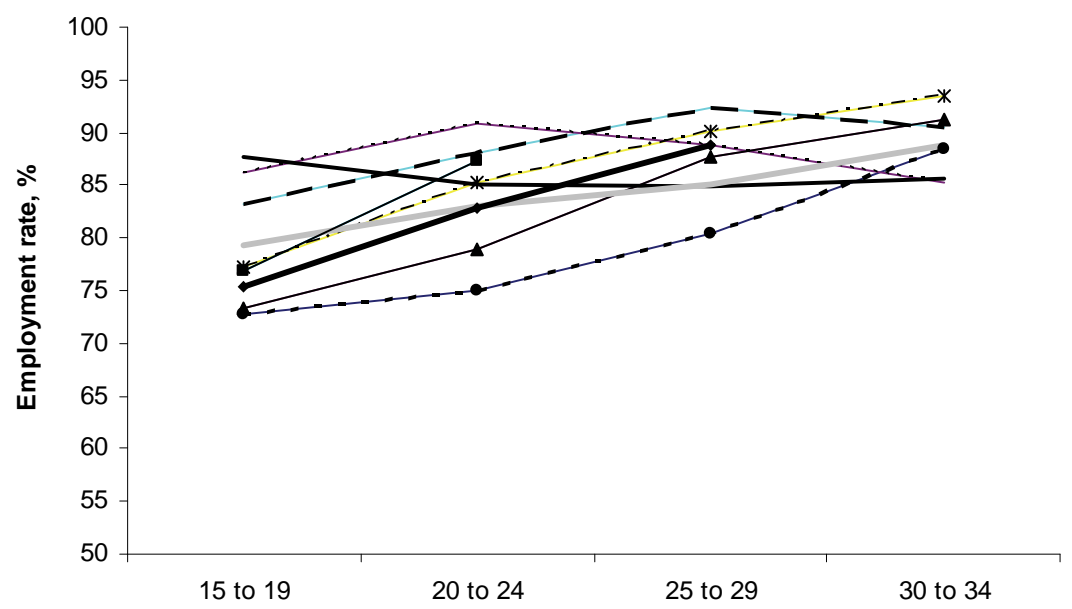

(b) Cohort specific employment rates - the old

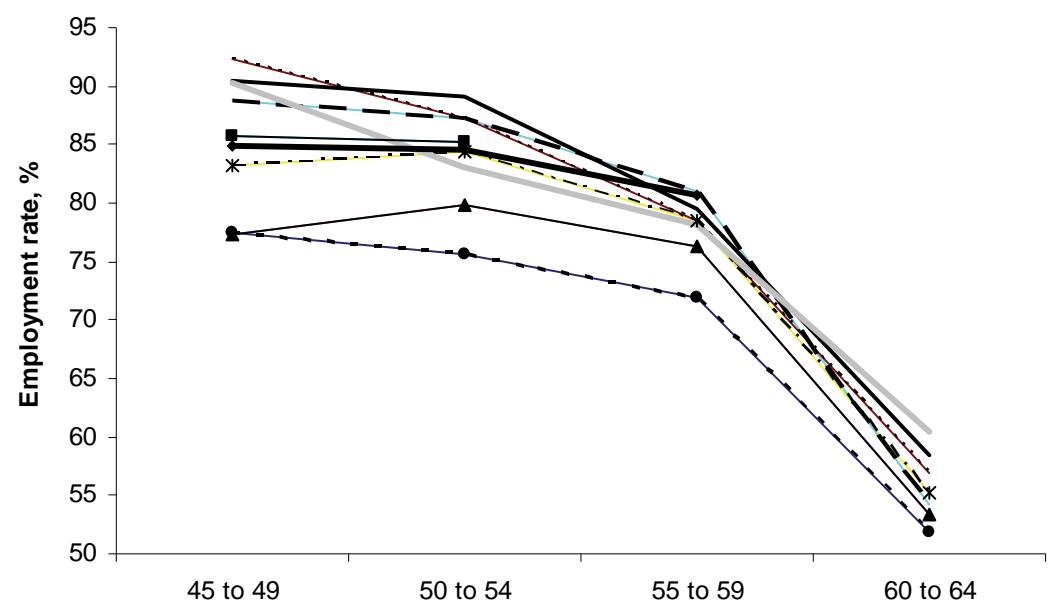

Figure 7. Employment persistence across cohorts - young and old, Sweden Source: Own calculations based on data from www.sourceoecd.org.

Note: The data are for five-year age groups which are used to form average histories for five-year cohorts. Data are available from 1960 to 2008 (in some cases only a shorter sample is available). Each line in the figure corresponds to a different cohort. 
older workers and thus produce persistent effects on the overall employment rate for a period of 15-20 years. ${ }^{9}$ Similar patterns are found for Denmark, Norway and Finland.

There is thus an argument that a deep recession reducing employment will lower employment rates for those above 40 for the rest of their labor market career, while there is no clear sign of such an effect for younger workers. This may be explained by human capital depreciation, a higher risk for older workers that knowledge and experience become obsolete, a shorter labor market horizon and scope for early retirement. The potential persistence here evolves over a period of 15-20 years and is thus by no means trivial.

The point of this is that while there is reason to be concerned about the risk of long-term unemployment and hence persistent declines in employment rates, it does not follow that demand management policies are the appropriate policy tool. Active labor market policies are better targeted at this problem, and have also in the past been conducive in reducing unemployment. There is thus a concern whether there is an appropriate policy balance between traditional aggregate demand management policies and active labor market policy. The increase in unemployment causes a cost increase for active labor market policies if the same individual program intensities should be maintained. While there are arguments that the marginal value of a given activity is lower in a recession and therefore that costs should not increase proportionally to unemployment, there is a concern that active labor market policies are underprioritized relative to traditional aggregate demand measures. ${ }^{10}$

Previously, unemployment problems have also been addressed by creating pathways out of the labor force via various forms of early retirement, disability pensions etc. Experience from the past clearly shows that such policies are not the solution to the unemployment problem, but contribute to a permanent reduction in employment and a burden on public finances. No such policies have been implemented as crisis measures, but this does not imply that such pathways do not exist since existing systems may become

\footnotetext{
${ }^{9}$ Individual vs aggregate data: it is possible that there is persistence at the individual level, but not at the aggregate level via endogenous labor supply (in favorable periods new workers enter the labor market).

${ }^{10}$ OECD (2009a) shows that while there have been significant discretionary changes in fiscal policy in most countries, this does not apply to active labor market policies.
} 
more used. Hence, there is a potential channel here through which the crisis may produce a persistent decline in employment rates.

\subsection{Retirement/pension reforms and aggregate demand}

The debate on exit strategies centers on the premise that a reform which improves fiscal sustainability is necessarily harmful for aggregate demand and thus activity in the short run. This may lead to a postponement of the needed reforms and thus a worsening of the adjustment problems.

Such a dilemma need not exist for all forms of structural reforms which can improve fiscal sustainability. An important policy issue is how to address the changing demographic structure, and therefore retirement and pension reforms are on the agenda in most countries. It has been suggested that well-structured retirement reforms may improve public finances in the medium to long run and thus fiscal sustainability, and they may lead to more aggregate demand in the short run (Barell et al., 2009). If there are policy reforms releasing such a double dividend, they are clearly attractive since they will escape the tension between short- and long-run consideration underlying the debate on exit strategies.

Consider a reform increasing the statutory retirement age (possibly gradually). If tax financed pensions are provided from the statutory retirement age, it follows that the pension expenditures decrease, and hence fiscal sustainability is improved. This is a straightforward implication of changing the balance between the number of years contributing and benefitting from the scheme.

The individual response to this depends crucially on whether the actual retirement age is determined by the statutory retirement age. If this is the case, the incentive to save is reduced since more labor income will be earned (and this may also possibly increase contributions into labor market pensions), see Andersen (2010). Younger cohorts planning to retire at the statutory retirement age will therefore save less, and, as a consequence, consumption and thus aggregate demand will increase. This is illustrated in Figure 8 based on a simulation with the DREAM model for the Danish economy; see DREAM (2009). For illustrative purposes the figure shows the consequences of a hypothetical reform where retirement ages are increased by closing the early retirement scheme from 2011. Panel a in Figure 8 shows the effects of such a reform on aggregate private consumption, and panel $b$ 
(a) Effect on private consumption

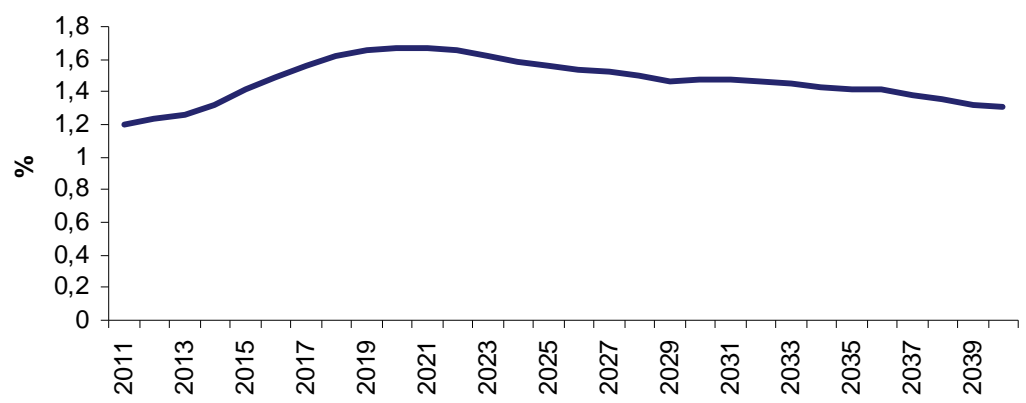

(b) Effect on primary budget balance, \% of GDP

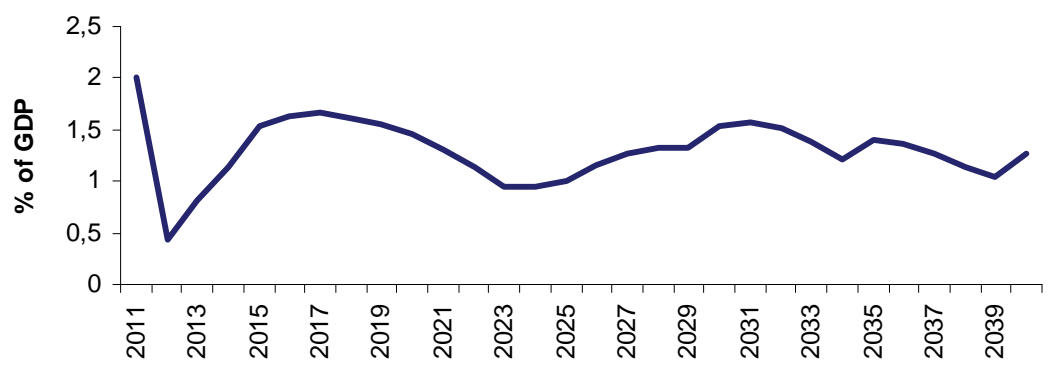

Figure 8: Effects of retirement reform on private consumption and the primary balance Source: Simulation with the DREAM model.

Note: The figure shows the effects of the reforms as the difference from the base scenario in DREAM (2009). Note that the public budget is affected by both repayment of early retirement contributions and the interaction between the reform and the changes of the scheme embedded in the base scenario.

gives the effect on public finances. The reform improves fiscal sustainability by almost 1 percentage point of GDP and thus has a significant effect on fiscal sustainability at the same time as it has a strong effect on aggregate demand. This shows that there is not necessarily a tension between structural reforms aimed at improving fiscal sustainability and short-run concerns about aggregate demand. 
The reasoning above relies on the assumption that the actual retirement age is determined by the statutory retirement age. ${ }^{11}$ If this is not the case, the effects may be the opposite. A person planning retirement earlier than the statutory retirement age will experience a drop in the implicit pension wealth arising from entitlement to the tax-financed pension. This income loss may induce the individual to retire later, but also to save more; see Andersen (2010).

Whether actual retirement ages follow statutory retirement ages depends on several factors including the design of pension schemes and norms/expectations concerning retirement. In some countries, the pension scheme is designed with a well-defined statutory retirement age (e.g., the Danish), while in others there is a more open choice with a minimum age at which pensions can be withdrawn. This is the case in Sweden, and recent reforms in Norway and Finland are moving in the same direction. However, empirically one observes a strong clustering of actual retirement around statutory retirement ages. This can be taken as evidence either of the importance of the kink created by the pension scheme or that there are very strong norms related to retirement (leisure externality argument) where the statutory retirement age creates a focal point with a strong influence on actual behaviors.

However, even if the link between statutory and actual retirement ages is less tight, it remains that the effects of retirement/pension reforms on aggregate demand may be smaller than the effects of alternative reforms reducing public consumption or raising taxes with the same effect on fiscal sustainability. Hence, it is not obvious that structural reforms improving fiscal sustainability should necessarily be put on hold due to the crisis.

\section{Intermediary targets and fiscal policy frameworks}

The current crisis underlines the importance of both consolidation and credibility. Countries that have managed to consolidate public finances prior to the crisis have a much better starting point for accommodating the consequences of the crisis and thus more degrees of freedom in their economic

\footnotetext{
${ }^{11}$ In the simulation it is assumed that 90 percent of those who are on early retirement in the base scenario would be working post the reform.
} 
policy. This is clearly exemplified by countries like Greece, Ireland and the UK, which find themselves in a very difficult situation with very urgent needs to address public finance problems and with little scope for finetuning exit strategies. Equally important is the credibility established in setting and reaching certain targets for fiscal policy which creates a political asset yielding a return in terms of higher credibility to announced future changes in fiscal policy. For an overview of intermediary fiscal policy targets in the Nordic countries see Table 3.

In formulating an exit strategy, it is thus important to safeguard credibility and to enhance it by setting well-defined targets for fiscal policy. While the overriding objective is to ensure fiscal sustainability, the sustainability indicator is not an appropriate intermediary policy target. The indicator is difficult to interpret and communicate, and, as discussed above, it does not translate into a clear policy response. It is necessary to formulate intermediate targets as guidelines for economic policy decisions which make it possible to evaluate the extent to which policy is on track. This is needed to create discipline and credibility.

The setting of intermediary fiscal targets has to take into account both a filtering and a response problem. The filtering problem refers to the fact that there is an inherent information problem in assessing the initial situation (structural budget balance) and whether shocks are temporary or permanent in nature. All of this is very important for assessing public finances, and since new information arrives continuously, there is also an underlying learning or filtering problem. The response problem refers to how deviations from targets are to be handled; that is, when and how should deviations be addressed? Moreover, responding to any deviations from target may lead to excessive policy change, and some smoothing is called for.

The underlying uncertainty and the problem of unraveling the underlying state of the economy are arguments for having a portfolio of intermediary measures since they all have pros and cons. The primary advantage is that many targets imply some risk pooling and allow some learning. A disadvantage is that it leaves open when to react (when one or all measures are off target?), but also that it creates lack of transparency since policy makers may shift between targets depending on performance; i.e., it is more difficult to hold policy makers accountable with several targets. Overall this goes in the direction of having few/one intermediary target(s). 
Table 3. Intermediary targets for fiscal policy Nordic countries

\begin{tabular}{|c|c|c|c|c|}
\hline & Denmark & Finland & Norway & Sweden \\
\hline Targets & $\begin{array}{l}\text { 2010-plan: } \\
\text { Real public } \\
\text { consumption } \\
\text { growth } \\
\text { Debt reduction } \\
2015 \text {-plan: } \\
\text { Public consump- } \\
\text { tion to constitute } \\
\text { no more than } \\
26.5 \% \text { of GDP } \\
\text { in } 2015 \\
\text { Structural } \\
\text { budget balance } \\
\text { in the interval } 3 / 4 \\
\% \text { to } 13 / 4 \% \text { of } \\
\text { GDP }\end{array}$ & $\begin{array}{l}2003-2007 \\
\text { Expenditure } \\
\text { targets set for } \\
\text { the election } \\
\text { period } \\
\text { Structural } \\
\text { budget balance: } \\
1 \% \text { of GDP } \\
\text { Deficits not to } \\
\text { exceed } 2 \% \text { of } \\
\text { GDP except in } \\
\text { deep recessions }\end{array}$ & $\begin{array}{l}\text { Stabilization } \\
\text { fund (Income } \\
\text { smoothing - } \\
\text { 2000): An } \\
\text { expected return } \\
\text { of } 4 \% \text { on the } \\
\text { wealth in the } \\
\text { state pension } \\
\text { fund to be used } \\
\text { annually } \\
\text { Allows for } \\
\text { automatic } \\
\text { stabilizers to } \\
\text { operate }\end{array}$ & $\begin{array}{l}\text { Rolling expendi- } \\
\text { ture targets for the } \\
\text { coming three years } \\
\text { Surplus target: } \\
\text { Budget surplus: } \\
1 \% \text { of GDP on } \\
\text { average over the } \\
\text { business cycle }\end{array}$ \\
\hline \multirow{5}{*}{$\begin{array}{l}\text { Pensions } \\
\text { and retire- } \\
\text { ment reforms }\end{array}$} & \multirow{3}{*}{$\begin{array}{l}\text { Welfare reform } \\
2006 \text { : } \\
\text { Increase in } \\
\text { statutory early } \\
\text { retirement and } \\
\text { pension age by } \\
2 \text { years in steps } \\
\text { from } 2019-2026\end{array}$} & \multirow{3}{*}{$\begin{array}{l}\text { Pension reform } \\
\text { 2005: } \\
\text { Closer link } \\
\text { between wage } \\
\text { income and } \\
\text { pension } \\
\text { Restricting early } \\
\text { retirement }\end{array}$} & $\begin{array}{l}\text { Pension reform } \\
\text { 2009: }\end{array}$ & $\begin{array}{l}\text { Pensions reform } \\
\text { 1991: }\end{array}$ \\
\hline & & & $\begin{array}{l}\text { More flexible } \\
\text { retirement } \\
\text { (actuarial) }\end{array}$ & $\begin{array}{l}\text { Notional defined } \\
\text { contribution } \\
\text { scheme }\end{array}$ \\
\hline & & & $\begin{array}{l}\text { Closer link } \\
\text { between wage } \\
\text { income and }\end{array}$ & $\begin{array}{l}\text { Closer link be- } \\
\text { tween wage } \\
\text { income and pen- }\end{array}$ \\
\hline & Thereafter & Benefit at given & pension & sion \\
\hline & $\begin{array}{l}\text { Indexation to lite } \\
\text { expectancy so } \\
\text { as to target an } \\
\text { average retire- } \\
\text { ment period of } \\
191 / 2 \text { years }\end{array}$ & $\begin{array}{l}\text { age dependent } \\
\text { on longevity } \\
\text { Target to in- } \\
\text { crease average } \\
\text { retirement age } \\
\text { by } 3 \text { years by } \\
2025^{\text {a }}\end{array}$ & $\begin{array}{l}\text { Benefit at given } \\
\text { age dependent } \\
\text { on longevity }\end{array}$ & $\begin{array}{l}\text { Benefit at given } \\
\text { age dependent on } \\
\text { life expectancy+ } \\
\text { more }\end{array}$ \\
\hline $\begin{array}{l}\text { Independent } \\
\text { monitoring }\end{array}$ & $\begin{array}{l}\text { Economic } \\
\text { council }\end{array}$ & & & $\begin{array}{l}\text { Fiscal policy } \\
\text { council }\end{array}$ \\
\hline
\end{tabular}

Source: Ministry of Finance Denmark (2010), Ministry of Finance Finland (2010), Ministry of Finance Norway (2009a,b), and Ministry of Finance Sweden (2010).

Note: a) Pension reform is expected to lead to an increase in the average retirement age by $1 \frac{1 / 2}{2}$ years, Ministry of Finance Finland (2010).

The ideal target is measured at regular intervals, well defined (not based on assessments or estimates), well understood and closely related to policy instruments with a clear affinity to political negotiations. It is hard to think of any intermediary target fulfilling all these requirements. The debt level fulfils most, but it is subject to variations beyond policy control (asset price variation) and does not directly relate to policy decisions. The budget balan- 
ce is closer to the budget process and therefore better in this respect, but suffers from high sensitivity to the current economic situation. The Swedish moving average target for the budget balance requiring that the average of the current year, the past three years, and the coming three years' projected balance should meet the target value can be seen as a reasonable pragmatic solution addressing both the filtering and response problems. However, it is not without problems since systematic overoptimistic projections may ensure that the target is met ex ante, although there is a systematic ex post deviation (see Swedish Fiscal Policy Council, 2009). This problem can be overcome by relying on external budget forecasts.

In short, pragmatism is unavoidable, but it is important to set few and clearly defined intermediary targets. Moreover, it is important to ensure continuity in targets upon revision (not changing target variables) and consistency in targets. ${ }^{12}$ For political reasons, targets should be set for some planning period and then revised in light of new information and the track record.

Targets serve the purpose of planning but also of accountability via increasing the political costs of opportunistic policies. This may be further strengthened by some external independent fiscal policy board. This role is served in Denmark by the Economic Council and in Sweden by the Fiscal Policy Council.

\section{Concluding remarks}

The deterioration in public finances calls for action. The most important response is in most cases structural reforms which ensure fiscal sustainability. In practice this translates into removing the trend from the budget. Such reforms are important for credibility and may even work to stabilize the economy in the short run. Further consolidation is needed, and it is important to time this to business cycle developments. However, if reforms have

\footnotetext{
${ }^{12}$ If the policy objectives have been clarified, a trajectory for public revenues ( $T$ ), expenditures (G), the primary budget balance (B) and the public debt level (D) is implied. From these, other intermediary targets for e.g., the employment level may be derived. In principle, all of these variables could be made intermediary targets for fiscal policy to ensure that the path underlying fiscal sustainability is fulfilled and various policy objectives are reached. Of course, these variables are interrelated since a given path for $\mathrm{T}$ and $\mathrm{G}$ implies a path for $\mathrm{B}$, and the path for $\mathrm{B}$ determines $\mathrm{D}$ (given projected interest rates, etc.).
} 
addressed the sustainability problem, there is a less strong urge for such immediate consolidations, thereby making it easier to time policy reactions to the business cycle situation.

For EU countries there is a particular issue with respect to meeting the requirements of the Stability and Growth Pact, and most countries have deficits which release reactions from the "excessive deficit procedure" (European Commission, 2009c). This will in practice imply calls for plans to bring budgets in accordance with the 3 percent budget norms no later than 2013 (for most countries). While it is important to meet these demands, it is more important that proper structural reforms are undertaken. Accomplishing the budget targets via short-term consolidations and postponing structural reforms addressing fundamental unbalances are likely to have large costs. This applies in terms of both the short- and long-run effects. It should also be noted that the reinterpretation of the SGP in 2005 allowed for more leeway in undertaking the necessary structural reforms rather than a strict adherence to the budget rules in the very short run.

To ensure credibility, it is important to have well-defined targets for fiscal policy which can be easily monitored and which allow for political accountability. Therefore, clear announcements should be made on how to address public finance problems via both structural reforms and more immediate consolidation efforts.

\section{References}

Andersen, T.M. (2005), The role for an active fiscal stabilization policy, CESifo Studies 51, 511-547.

Andersen, T.M. (2008), Changing demographics and fiscal sustainability - should we save or work more?, CEPR Discussion Paper 7044.

Andersen, T.M. (2010), Retirement reform and aggregate savings, Manuscript, Aarhus University, Aarhus.

Andersen, T.M. and Pedersen, L.H. (2006), Assessing fiscal sustainability and the consequences of reforms, in European Economy, Economic Papers 248, European Commission, Brussels.

Barell, R., Hurst, I. and Kirby, S. (2009), How to pay for the crisis or macroeconomic implications of pensions reform. NIESR Working Paper 333, London.

Barro, R. (1979), On the determination of the public debt, Journal of Political Economy $87,940-71$.

Bi, H. and Leeper, E.M. (2010), Soveriegn debt risk premia and fiscal policy in Sweden, Studier i finanspolitik 2010/3, Swedish Fiscal Policy Council, Stockholm. 
Corsetti, G., Meier, A. and Müller, G. (2009), Fiscal stimulus with spending reversal, IMF Working Paper WP/09/106.

DREAM (2009), Langsigtet økonomisk fremskrivning 2009, Copenhagen.

European Commission (2006), Long-term sustainability of public finances in the EU, European Economy 4, Brussels.

European Commission (2009a), Sustainability Report 2009, European Economy 9, Brussels.

European Commission (2009b), Economic crisis in Europe: Causes, consequences and responses European Economy 7, Brussels.

European Commission (2009c), Excessive deficit procedure steps: The stability and growth pact as the anchor for fiscal exit strategies, Brussels.

Giudice, G., Turrini , A. and in't Vald, J. (2003), Can fiscal consolidations be expansionary in the EU? Ex-post evidence and ex-ante analysis, European Economy, Economic Papers 195, European Commission, Brussels.

Girouard, N. and André, C. (2006), Measuring cyclically-adjusted budget balances for OECD countries, OECD working paper 434, Paris.

Gordon, R. and Varian, H.R. (1988), Intergenerational risk sharing, Journal of Public Economics 37, 185-202.

IMF (2009), Global economic prospects and principles for policy exit, paper for G20 meeting, Washington, D.C.

Ministry of Finance - Denmark (2010), Danmarks konvergensprogram 2009, Copenhagen.

Ministry of Finance - Finland (2010), Stability programme update for Finland 2009, Helsinki.

Ministry of Finance - Sweden (2010), Stability programme update for Sweden 2009, Stockholm.

Ministry of Finance - Norway (2009a), Perspektivmeldingen 2009, Oslo.

Ministry of Finance - Norway (2009b), Natsjonalbudgettet 2010, Oslo.

OECD (2009a), The Financial Crisis - Reform and Exit Strategies, Paris.

OECD (2009b), Economic Outlook 86, Paris.

Reinhart, C., and Rogoff, K. (2010), Growth in a time of debt, CEPR Discussion Paper 7661.

Swedish Fiscal Policy Council (2009), Fiscal policy in Sweden 2009, Stockholm. van der Ploeg, F. (2008), Structural reforms, public investment and the fiscal stance: A prudent approach, Studier i finanspolitik 2008/3, Swedish Fiscal Policy Council, Stockholm. 


\section{Appendices}

\section{A.1. Fiscal sustainability indicator}

From (1) we have

$$
E_{t}\left[\sum_{i=0}^{\infty}\left(\frac{1}{1+r}\right)^{i} b_{t+i}\right]+\frac{1+r}{r} s_{t}=(1+r) d_{t-1}
$$

Leading this one period gives

$$
b_{t+1}+E_{t+1}\left[\left(\frac{1}{1+r}\right) b_{t+2}+\left(\frac{1}{1+r}\right)^{2} b_{t+3}+++\right]+\frac{1+r}{1} s_{t+1}=(1+r) d_{t}
$$

Multiplying (4) by $(1+r)^{-1}$ and subtracting from (3) give

$$
\begin{aligned}
& b_{t}+\left(\frac{1}{1+r}\right)\left[E_{t} b_{t+1}-b_{t+1}\right]+\left[\sum_{i=0}^{\infty}\left(\frac{1}{1+r}\right)^{2+i}\left[E_{t} b_{t+2+i}-E_{t+1} b_{t+2+i}\right]\right] \\
& +\frac{1+r}{r} s_{t}-\frac{1}{r} s_{t+1}=(1+r) d_{t-1}-d_{t}
\end{aligned}
$$

Note that $\quad E_{t+1} b_{t+1}=b_{t+1}$. Using that $d_{t}=(1+r) d_{t-1}-b_{t}$ we get

$$
s_{t+1}=[1+r] s_{t}+\frac{r}{1+r}\left[E_{t} b_{t+1}-b_{t+1}\right]+\frac{r}{1+r} \Psi_{t+1}
$$

Where

$$
\Psi_{t+1} \equiv\left[\sum_{i=0}^{\infty}\left(\frac{1}{1+r}\right)^{1+i}\left[E_{t} b_{t+2+i}-E_{t+1} b_{t+2+i}\right]\right.
$$




\section{A.2. Intergenerational risk sharing}

This appendix clarifies the different scope in diversifying transitory and permanent shocks via automatic stabilizers. For the sake of argument, consider the limiting case where there is no private capital market for human capital, implying that all agents are liquidity constrained; that is, consumption (C) is equal to current (labor) income (Y) assumed to be time dependent, i.e. $C_{t}=Y_{t}$. Assume that agents are infinitely lived with a utility function defined over consumption

$$
\sum_{j=0}^{\infty} \beta^{j} U\left(C_{t+j}\right)
$$

where $\beta$ is the subjective discount factor. It is a straightforward implication of risk aversion $\left(U^{\prime}>0, U^{\prime \prime}<0\right)$ that there are welfare gains to be reaped by smoothing consumption. Since this is not possible for private agents due to capital market incompleteness, the question is what type of smoothing should be offered by the public sector.

Consider first the optimal consumption smoothing a central planner will choose if resources can be transferred over time via e.g., an international capital market at a real rate of return $r$ (assumed constant). In this case the intertemporal budget constraint reads

$$
\sum_{j=0}^{\infty}\left(\frac{1}{1+r}\right)^{j} C_{t+j}=\sum_{j=0}^{\infty}\left(\frac{1}{1+r}\right)^{j} Y_{t+j}
$$

where $r$ is the market interest rate (assumed constant for simplicity). Consumption smoothing implies that

$$
C_{t+j}=C=\frac{r}{1+r} \sum_{j=0}^{\infty}\left(\frac{1}{1+r}\right)^{j} Y_{t+j}
$$

It is an implication that consumption should adapt to a transitory change in demand by $\frac{\partial C}{\partial Y_{t+j}}=\frac{r}{1+r}$ 
and to a permanent change in income by

$$
\frac{\partial C}{\partial Y} \mid Y_{t+j}=Y=1
$$

The basic point is that optimal smoothing or risk diversification calls for different adjustment to transitory and permanent changes in income. This insight clearly generalizes beyond the specific example considered here.

\section{A.3. Can a temporary fiscal expansion improve fiscal sustainability?}

The metric of the automatic stabilizers is given by the semi-elasticity

$$
\alpha \equiv \frac{\partial\left(\frac{B}{Y}\right)}{\frac{\partial Y}{Y}}
$$

and, for a particular fiscal instrument, the output multiplier is

$$
m \equiv \frac{\partial Y}{\partial G}
$$

Let output measured in deviations from trend be

$$
\tilde{Y}_{t}=\rho \tilde{Y}_{t-1}+\varepsilon_{t}
$$

where the shock has two components, the exogenous shock $\mathrm{z}(<0)$

and the effect of fiscal policy ( $m d g, d G>0$ ), hence $\varepsilon=z+m d G$. In the following calculation, both the shock and the fiscal intervention are taken to be temporary; that is, the persistence referred to above (captured by $\rho$ ) relates to endogenous persistence due to adjustment lags and problems of various sorts.

Define the budget balance relative to GDP by b, i.e. $\quad b_{t} \equiv \frac{B_{t}}{Y_{t}}$ Denote by $\tilde{b}_{t}$ the deviation in the budget-to-GDP ratio caused by trend deviations in output, we have, $\tilde{b}_{t+1}=\alpha \tilde{Y}_{t}$ and hence $\tilde{b}_{t+1}=\alpha \tilde{Y}_{t}=\alpha\left(\rho \tilde{Y}_{t-1}+\varepsilon_{t}\right)$ 
We thus have that the present value effect of a current fiscal stimulus, taking into account the future effects running via endogenous persistence and automatic stabilizers, reads

$$
\begin{aligned}
P V(d G) & =\left[-1+\tilde{b}_{t}+\frac{1}{1+r} \tilde{b}_{t+1}+\left(\frac{1}{1+r}\right)^{2} \tilde{b}_{t+2}++++\right] d G \\
& =\left[-1+\alpha m \frac{1+r}{1+r-\rho}\right] d G
\end{aligned}
$$

The question is whether a temporary fiscal stimulus can improve fiscal sustainability, $\quad P V()>0$ i.e., which requires

$$
\alpha m>\frac{1+r-p}{1+r}
$$





\title{
Fiscal policy and labor markets at times of public debt*
}

\author{
Giuseppe Bertola **
}

\begin{abstract}
Summary
This paper explores the empirical relevance of public debt accumulation for labor market institutions and outcomes. In theory, since debt service obligations act as a constraint on policy choices, past debt accumulation and current interest rates should influence reform incentives and labor market performance. Empirically, employment and unemployment rates are strongly associated with debt stock and debt service indicators over five-year periods along public debt and interest-rate stabilization cycles (1980-2000). Significant and sensible relationships are apparent between debt service, interacted with country-specific policy indicators, and labor market policy changes. While only further data and research might disentangle the forces that jointly shape public finance and labor market developments, past evidence suggests that aggregate fiscal policy reactions to the 2008-09 crisis will have persistent labor market implications.
\end{abstract}

Keywords: Employment, Unemployment, Debt Stabilization JEL Classification Numbers: J08, H60

${ }^{*}$ Revised and extended version of a paper presented at the Nordic Economic Policy Conference (Copenhagen, 22 March 2010). The author benefited from comments received during and after that meeting, in particular from Torben Andersen, Xavier Debrun and Steinar Holden, but remains responsible for any errors and opinions.

${ }^{* *}$ Università di Torino and CEPR. 
Like any other fiscal instrument, labor taxes and employment or unemployment subsidies trigger market responses (Tullio, 1987). Labor taxes affect their own base by decreasing employment incentives; in-work subsidies similarly generate deadweight losses when the composition of employment responds endogenously to their availability. Even more obviously, more generous unemployment subsidies tend to increase unemployment. Employment protection legislation (EPL) has no direct implications for government finances, and does not generally affect average employment. But EPL, too, decreases a country's tax base, because it lowers productivity by preventing efficient labor reallocation. Of course, the fact that labor market policies (like most taxes) are expensive in terms of output efficiency does not deny that they can be useful, in the sense that their main purpose is not maximization of aggregate employment and output. Labor taxes, subsidies and EPL aim at protecting workers from wage variability and job losses, as well at redistributing income towards disadvantaged individuals. The balance of costs and benefits of various policies should determine their character and intensity.

This paper focuses on interactions between labor markets and public debt accumulation. Labor market policies have no direct impact on a government's deficits if its budget is balanced, i.e., if the revenue of labor taxes is used to finance unemployment and employment subsidies. But to the extent that interference with labor markets reduces aggregate employment and productivity, it will be harder for policymakers to address risk and distribution issues when such effects are more detrimental. One source of variation in the affordability of labor market policies is the need to service public debt, which originates from previous policy choices. When public debt is low, higher unemployment and lower (or expensively subsidized, or misallocated due to EPL) employment may appear to be an acceptable price for desirable redistribution of risk and resources. The same combination, however, may be out of reach when tax revenue has to be tasked for the purpose of servicing or reducing debt. As even budget-balanced labor market policies reduce employment and output (if not welfare), they decrease the denominator of public debt/GDP ratios, increase their growth rates, and endanger the sustainability of public finances.

Section 1 outlines these theoretical considerations in the context of a brief review of related strands of the literature. In an attempt to characterize the empirical menu of policy choices and policy consequences in the after- 
math of the crisis, Section 2 provides an analysis if empirical relationships between public finance indicators and labor market policies and outcomes in the aftermath of the labor market unrest and oil shocks during the 1970s, when both unemployment and public debt rose more or less persistently in many advanced countries. The concluding Section 3 outlines the implications of the perspective and empirical results in this paper for the evolution of labor market policies and outcomes in the aftermath of large public debt accumulation during the 2008-09 crisis, and for further research.

\section{Labor market and fiscal policies}

In the recent financial crisis, fiscal deficits have played a major role, as a result of both tax revenue loss and policy responses. Government deficits are beneficial in a crisis because, unlike many workers and - when financial markets malfunction - most firms as well, governments can borrow to smooth out the implications of temporary shocks. Within government budgets, policies targeted at the labor market have been prominent in many countries. In Germany and Italy, for example, the Kurzarbeit and Cassa integrazione guadagni in deroga short-work and temporary layoff programs have subsidized permanent employment relationships. In other countries, the crisis triggered large expenditures on income and job-search support to permanently displaced workers.

It may be too early to assess which of these policy responses was more appropriate. The answer depends on whether the shock will prove to be just a manifestation of financial difficulties and temporary aggregate demand shortages, or will instead call for permanent restructuring and reallocation. Instead, it is already possible, and useful, to characterize the longer-term motivations and implications of different labor market policy instruments for labor market and debt outcomes.

\subsection{Labor market policies}

The aggregate balance of taxes and subsidies can smooth aggregate demand shocks in labor and product markets. Similarly, the distribution of taxes and subsidies across workers and households can smooth consumption over individual labor market shocks. A large literature (reviewed in e.g., Bertola, 
2009) studies the character and intensity of institutional influences on labor market outcomes, which differ substantially across countries. Efficient allocation and flexible reallocation of employment usually require effort by workers, for whom changing jobs is costly. In laissez-faire labor markets, such efforts need to be prompted by wage variability across more or less productive workers and jobs. Since it is difficult and important for individuals to be sheltered from the excesses of such variability, labor-market institutions aim at reducing ex post inequality of outcomes for ex ante similar individuals, and/or at redistributing resources across different individuals. At the same time, they all affect aggregate employment and output negatively.

Unemployment insurance makes it less painful to become and remain unemployed, but unavoidably reduces workers' incentives to avoid job loss and seek new jobs. Like any other subsidy to non-employed individuals (such as pensions, cf. Disney, 2004), unemployment subsidies need to be funded by taxing income, and labor taxation reduces labor force participation and employment. Employment protection legislation reduces the likelihood of job loss for uninsured workers. But it also shifts the costs of adjustment to employers, and reduces total production as employment stability comes at the price not only of less job destruction but also of less creation of more productive jobs. In an attempt to reconcile flexible reallocation and work incentives with the objective of sheltering labor incomes from risk, public training programs, in-work subsidies, and other active labor market policies combine forms of income support with measures intended to ensure that labor is not idle (as it might be in a simple unemployment benefit program) or employed in low-productivity jobs (as employment protection tends to imply). Such policies can combine "security" with "efficiency", but they are expensive. This third "fiscal” aspect of the labor market policy trilemma explains why the Danish flexicurity approach yields high levels of employment and security at the same time as it draws some 5 percent of GDP into funding of labor market policies.

As Table 1 shows, different countries choose different combinations of these policies, and feature different levels of wage inequality. The grouping of countries in Table 1 follows the standard Esping-Andersen (1999) classification, which reflects underlying social and political determinants of the desirability of labor market intervention, and of the relative costs of various instruments in terms of tax collection and administrative aspects. In Table 2, 
we see that the unemployment and employment rates implied by labor market policy models also differ.

Since many labor market policy instruments are fiscal in nature, and all have fiscal implications through their employment effects, it is natural to wonder how policies and outcomes may be shaped by aggregate government budget developments.

\subsection{Public debt}

High unemployment and/or inefficient employment may or may not be politically acceptable and generously subsidized, depending on individual countries' political and economic circumstances. If the same countries are burdened by high public debt, however, their politico-economic equilibrium can only be shifted towards less intrusive labor market policies.

Needless to say, public debt is not a completely natural phenomenon. Its accumulation reflects policy choices as well as past shocks. Government deficits can be an effective stabilization tool in the face of macroeconomic fluctuations. For debt financing of government expenditure to matter at all, of course, the financial link between current and future payments of taxes must be imperfect (so that "Ricardian equivalence" fails), because private agents, unlike governments, are finitely lived - or because, as the recent crisis made abundantly clear, financial markets are far from perfect even in the shorter run. Changes in deficits, aimed at offsetting the shocks to which the economy would respond improperly, make it possible for fiscal policy to exert its desirable stabilizing role.

In the absence of further unexpected shocks, further deficit spending does not sustain growth, and the path of debt would be unsustainable if debt service were met by persistent and growing deficits. Since the average level of deficits and the economy's nominal growth determine the dynamics of the public debt/output ratio, the stabilization of that ratio requires adjustment of taxes and expenditures.

Bacchiocchi, Borghi and Missale (2009) model the constraints imposed on various aspects of fiscal policy by past debt accumulation. They document that within the high-debt group of observations in their sample, high debt/GDP ratios are associated with lower public investment, lower public educational expenditure, and other policy indicators. In fact, debt sustainability concerns are stronger when high public debt/GDP may trigger self- 
fulfilling expectations of a debt crisis. When public debt is denominated in terms of a country's currency, it may be reduced in real terms by unexpected inflation. But if incentives to inflate are not kept in check by credibility, they will engender inflation expectations, and the high real interest rates that are realized if inflation does not materialize will depress output and boost debt/GDP ratios, thereby precipitating a crisis (Dornbusch, 1989). This mechanism may work through labor markets as well as through financial market channels. Hence, high debt and poor macroeconomic policy credibility can trigger a vicious circle of fast debt growth, low employment, and slow income growth when real wages are rigid, so that expected inflation also implies higher wage demands and, if monetary policy does not accommodate expectations, high realized interest rates.

Previous research has explored the relevance of nonlinearities, whereby the danger of such spirals affects realized growth rates more strongly when debt/GDP ratios exceed certain thresholds, as well as the empirical relevance of formal deficit and debt limits such as those enshrined in the EU's Stability and Growth Pact (Galì and Perotti, 2003). In country panel and long-history data, Reinhart and Rogoff (2010) find that debt/GDP ratios over 90 percent are associated with significantly lower growth rates than in lower debt/GDP groups. This may reflect the constraints, modeled and documented by Bacchiocchi et al. (2010), imposed by high debt repayment burdens on such growth-enhancing policies as educational expenditures. It may also, however, be a spurious reflection of the fact that high indebtedness and slow growth are both jointly caused by negative shocks, such as financial crises.

Other studies have also examined the character and effectiveness of different "fiscal consolidation" programs in the face of such concerns (Alesina and Perotti, 1996; Guichard et al., 2007). Deficit reduction is more often attempted by increasing taxes than by reducing expenditure, but is more likely to be permanent in the latter case; empirically, inflation is not an important factor of public debt reduction in advanced countries (Giannitsarou and Scott, 2006). More detailed evidence suggests that stabilization attempts tend to be accompanied by a cluster of reforms (Hauptmeier et al., 2007). Tagkalakis (2009) documents an interesting association between some structural reforms (such as a reduction in unemployment benefit replacement rate) and the incidence and success rate (defined as reductions by more than 1.5 percent of the deficit, with primary surplus persisting for three years) of fiscal adjustments. 
While all these empirical results have to be qualified by the rather small amount of information available on relatively rare and long-lived public finance problems (at least in advanced countries), the lower likelihood of fiscal adjustment success when taxes are the instrument of deficit reduction may reflect the type of negative feedback on which this paper focuses. If expenditure is rigid, and higher taxes decrease employment, a tax-based debt stabilization can sow the seeds of its own demise. Of course, the policy mix adopted by a specific country and its effects are shaped by many factors, and a particularly relevant one may be the impact of economic integration on a national government's tax powers. In an open economy, the tax burden has to be imposed on relatively immobile factors, such as labor, and implies larger employment effects if, as is likely, labor demand is more elastic in more open economies (Andersen and Skaksen, 2007; Bertola, 2006).

\section{Labor markets and public debt in the late $20^{\text {th }}$ century}

This section proceeds to examine past experiences in a set of standard labor market policy and outcome indicators, merged with equally standard public debt and deficit indicators (see the Data Appendix). In what follows, empirical relationships are illustrated by simple data plots over the entire available sample. They are analyzed by formal regressions on the post-1980 sample with complete information about both public finance and labor market indicators, and are interpreted, on a case-study basis, by examining specific countries' trajectories along the public debt and labor market spectrum.

\subsection{Labor market policies and outcomes}

In each of Figures 1-8, the left-hand side panel plots averages of five-year periods (see the Data Appendix) of the variables considered. The right-hand side panel removes the influence of permanent country-specific characteristics (such as those that determine membership in the groups examined in Tables 1 and 2) by showing deviations of the same variables from their mean across all observations available for each country.

Figure 1 shows that unemployment indeed tends to be high in countries and periods where unemployment insurance benefits are generous, and that the relationship is stronger along each country's time trajectory (shaped, 
among other things, by public debt accumulation or decumulation). Symmetrically, in Figure 2, labor tax rates are negatively related to employment rates. In figures not shown, the relationship between labor taxation and unemployment (as opposed to non-employment) is more nuanced, as theory predicts since taxes may or may not affect the difference between the returns to employment and those to job-seeking (Daveri and Tabellini, 2000; Pissarides, 1998). In Figure 3 we see that intense expenditure on active labor market policies is significantly (albeit expensively) associated with lower unemployment; the relationship between active labor market policies and the employment rate (not shown) is symmetrically positive.

Tables 3 and 4 document these relationships more formally, by assessing the statistical association of each policy indicator to both employment and unemployment, and in terms of multivariate regressions (with and without country and time effects) as well as of two-way associations of the type displayed in Figures 1 and 2. Of course, least-square regressions, even when they include a variety of policy indicators and control for unobserved characteristics, do not necessarily provide reliable estimate of policy effects. In fact, the coefficient estimates may spuriously reflect other factors that, while unobservable, may plausibly be related to both labor market outcomes and labor market policies. For example, unemployment may be high and unemployment insurance generous not just because the latter causes the former (as it undoubtedly does in theory to some extent), but also because policymakers increase the generosity of unemployment insurance at times when, for some other reason such as negative labor demand shocks in combination with wage rigidity, unemployment is high. Conversely, the negative employment effects of labor taxation may be less apparent in the data than in theory if taxes are high in countries where employment is, for other reasons, high and/or insensitive to taxation. Moreover, separate measurement of employment and unemployment rates is conceptually difficult, and the "willingness to work" criteria underlying the harmonized unemployment rates used in these regressions may in practice have different implications in countries with different cultures and different benefits schemes.

With these caveats in mind, it is interesting to find that unemployment insurance generosity has the theoretically expected positive coefficient for unemployment in all columns of Table 3. In Table 4, however, it is negatively associated with employment (as expected) only in multivariate regressions that control for other policies and for country effects (time effects are 
not significant). Labor tax rates display a consistently negative association with employment rates, which is weakened by inclusion of country and time effects, thereby indicating that labor taxation in the data tends to move in parallel over time. It is also found to be positively associated with unemployment, and more significantly so than unemployment insurance generosity. This would not be consistent with simple theoretical considerations if the latter indicator measured exhaustively and precisely the job-search and offer-acceptance effects it is meant to pick up. But it is difficult, of course, for the data to distinguish these effects from those (on labor demand and labor force participation) that tax rates are supposed to measure. The active labor market policy indicator always displays an unsurprisingly negative association with unemployment, and positive association with employment.

\subsection{Public debt and labor market outcomes}

Figures 4 and 5 plot the relationship between a conventional definition of public debt/GDP ratios and unemployment or employment rates (see the Data Appendix for definitions and sources). Theory predicts that when debt is high, employment should be low if debt calls for high labor taxes, and that unemployment should be low if debt calls for less generous subsidies. The evidence may be driven by such influences of high debt on labor market policies, but may also reflect other factors that shape either or both of the variables on the axes of the figures.

On balance, and on a five-year average basis that smoothes out most cyclical fluctuations, high debt is indeed negatively associated with employment (more or less strongly, depending on whether country-specific means are subtracted). It is positively associated with unemployment. In terms of the simple theoretical considerations above, this could be taken to indicate that countries in the sample have responded to persistently high unemployment with debt financing of unemployment subsidies, and/or have met debt financing needs more by raising taxes (thus implying lower employment) than by reducing unemployment insurance and other social expenditures (which would increase employment and lower unemployment). Of course, high unemployment and low employment may instead be jointly caused by the same economic problems that lead to debt accumulation. For this reason it will be important and interesting below to try and trace the sources of poor labor market performance in policies. 
The possible "threshold" character of sustainability concerns suggests that the relationship between public debt levels and policy may be different at different debt levels. Table 5 reports unemployment and employment rates in subsamples of yearly observations with different debt/income ratios. Labor market performance deteriorates steadily as debt increases to 90 percent of GDP, and does not deteriorate further beyond that. The change in this relationship happens to occur around the same 90 percent that Reinhart and Rogoff (2010) argue may trigger sharply slower growth. Here, however, the direction of the nonlinearity is the opposite. While growth may be negatively related to public debt only when public debt is very high, labor market outcomes are negatively related to public debt only when public debt is low, or moderately high. A more striking pattern is exhibited for labor market outcome variability within each indebtedness group: unemployment rates vary the most at intermediate levels of debt, thereby reflecting the variety of experiences across countries in that case (where debt may be increasing or decreasing); it is highest for employment rates for very high debt levels, which implies that different countries have reacted differently to potentially unsustainable debt accumulation.

The reasoning that motivates this paper suggests that public debt (while very visible) need not be the most relevant measure of fiscal constraints on labor market policies. The statistics and figures shown so far were based on the OECD "gross government financial liabilities" measure. The same source also provides a "gross government financial assets" measure (not as comparably defined across countries, e.g., because of differences in the importance and treatment of funded public pension funds and national railway debt), as well as the corresponding series of gross and net interest payments by government entities.

Tables 6 and 7 report four sets of regressions which relate unemployment and employment rates not only to (gross) public debt, but also to net public debt series obtained by subtracting government financial assets from it, as well as to gross and net government interest payments (all normalized by GDP and expressed in percentage points). The data are averages over the five-year (or shorter in the early 2000s) periods where labor market policy indicators, analyzed in the next subsection, are available from the data sources listed in the Data Appendix, from 1980-84 to 2000-2003.

In all cases, public debt and debt service indicators are significantly associated with unfavorable labor market outcomes. Across the various measures 
of public finance funding problems, the most significant appears to be "public interest payments (net)," which may indeed most closely represent the constraint imposed on labor market policies by public finance considerations. Its theoretical relevance and empirical usefulness are also strengthened by the fact that, unlike debt stock measures, it captures cross-country differences and time-series dynamics of interest rates as well as of debt stocks. Country dummies are strongly significant in all regression, thus reflecting the permanent employment and unemployment rate differences that may be partly attributed to the differences in welfare state policy configuration discussed and documented above. Period dummies are not significant, which indicates that the variables did not move in parallel across countries over time. In regressions not reported, cross-country differences in the slope coefficients of public finance indicators are neither individually nor jointly significant.

The regressions also allow for a nonlinear association between unemployment or unemployment rates and public finance indicators. Consistent with the simpler statistics in Table 5, non-linear terms are either insignificant, or their sign is opposite that of the corresponding linear term. This pattern is to a some extent driven by the presence in the sample of countries like Japan, with relatively low unemployment and very high debt (but low interest rate) for much of the sample. But controlling for country effects, or excluding Japan, does not remove evidence that the empirical association between public indebtedness and poor labor market performance is less pronounced when public finances are in very bad shape. In regressions not reported, when the linear and quadratic coefficients are allowed to differ across countries differences the slope effects are usually insignificant, and always completely insignificant as a group. While management of critical debt situations may well differ from that of more sustainable circumstances, it presumably does so differently, across countries and periods, in ways that are impossible to detect reliably in available data.

\subsection{Public finance problems and labor market policies}

When confronted with past debt accumulation, policymakers may choose simply to service existing debt stocks, or to reduce it more or less sharply. Governments' power to tax can back a very high debt level but, as discussed above, taxation generally damages effort incentives and production, espe- 
cially in open economies where private agents can react to taxation by withdrawing from their country's (taxable) markets to other countries' markets, rather than to autarky. Moreover, since governments have the power to renege on their debt obligations, by outright default or inflation, the temptation to do so can trigger sustainability crises.

While the intergenerational and macroeconomic implications of different debt paths and stabilization strategies vary considerably, they all affect the feasibility and desirability of labor market policies. This makes it interesting to try and detect the relationships between public finance problems and labor market policies that may mediate the association, discussed above, of the former with unemployment and employment rates.

As regards the overall empirical relationship between public debt and labor market policies, Figures $6-8$ show that, across all countries and periods, high debt is associated with higher labor taxes, but also with more generous unemployment insurance provisions (when country means are subtracted). The association between debt and active labor market policies is moderately negative: the countries that rely on such instruments may also be those that experienced relatively modest debt accumulation over the sample period, and/or (within country-specific trajectories) high debt-induced moderation in the use of expensive active labor market policies.

Over the rather short period for which data are available, public debt/output ratios display no tendency to mean-revert. Changes in that ratio are completely unrelated to their level (consistent with the evidence in, e.g., Faraglia, Marcet and Scott, 2008). The same, however, is not true of the ratio of net (or, indeed, gross) interest payments to GDP, a more theoretically appropriate measure of public finance sustainability problems. One way to assess the relationship between debt stabilization and labor market policies is to inspect how the intensity of debt service stabilization tendencies depends on whether labor taxes, unemployment insurance generosity, and active labor market policies are high or low. Since each instrument is used differently in different countries, "high" and "low" should be defined in relative terms within each country's trajectory. Table 8 reports regressions of the change in debt service on current debt service level. Over the whole sample of five-year averages, a significant mean-reverting tendency is observed. When the sample is split across observations for which each policy instrument is above or below its country-specific median value, mean reversion is significant when labor taxes are high, but also when unemployment 
insurance and active labor market policies are generous. This finding may indicate that (labor) tax-based reforms played a role in country-specific debt dynamics, while other policy instruments are not as sensibly related to public finance stabilization concerns. But the complicated pattern of signs and significance across individual policy indicators, and the joint significance of all three indicators as explanatory variables for employment and unemployment in Tables 4 and 5, suggest that for the purpose of controlling debt dynamics, different countries chose different combinations of policy changes, driven by international economic integration, political considerations and policy traditions.

Tables 9-11 report the coefficients detected by regression of labor market policy indicators on "public interest payments (net)," the most theoretically sound and empirically useful measure of public finance situations among those considered in Tables 6 and 7, and on its interactions with welfare state dummies that sort countries across the groups inspected in Table 1. The statistics refer to the size and significance of intercepts and slope deviations for the other groups with respect to Mediterranean countries, the reference group.

The results of this exploration can be only suggestive, of course, but do suggest that public debt developments were a significant determinant of heterogeneous policy patterns and reforms. In Table 9, the generosity of unemployment insurance systems is found to be (insignificantly) lower when and where debt service is more burdensome. This finding is not driven by country or time effects (the latter in fact strengthen the negative coefficient). It indicates that the positive association detected above between public debt and unemployment does not work through this (admittedly imprecise) indicator. When in debt, countries typically reduce the generosity of unemployment benefits, and the fact that unemployment is nevertheless higher reflects other factors. The welfare state level dummies have the expected signs; more interestingly, the Nordic and Continental countries that feature highly generous unemployment insurance also display a significant tendency to increase it in response to higher debt service (and other underlying problems). However, controlling for country dummies removes all significance from these group-slope effects, thus indicating that the data do not convey much information about the relationship between this particular labor market indicator and policy reactions to public indebtedness. 
The messages of Tables 10 and 11, where a similar exploration is carried out for the other labor policies, is similarly intriguing and imprecise. Labor taxes are robustly and positively related to public debt interest (net), which may be the reason underlying the negative relationship between high debt and low employment. It is again possible to detect a positive level effect in Nordic and Continental countries, which also appear to increase taxes less in response to public finance problems. Again, controlling for country dummies suffices to make all coefficients individually insignificant (while time effects, here and in the previous tables, are not significant). The pattern of signs and significance is similar for active labor market policies that are significantly reduced everywhere in response to higher public interest payments (consistent with the overall relationship detected above between public debt and unfavorable employment and unemployment developments). The response differs significantly across welfare state groups if the level is allowed to differ only across those groups; when country dummies absorb most of the variation, only the (negative) slope of Nordic countries remains significant.

\subsection{Two country stories}

Unsurprisingly, as illustrated by the effect of country dummies in the regressions above, it is difficult to detect strong empirical regularities in limited data. Policymaker's choices along the public finance and labor market menu of rocks and hard places are simply too heterogeneous and variable to be characterized simply. The data do offer intriguing indications of empirical relevance for the channels explored in this paper, however. To highlight them further, it is interesting to examine the policy trajectories followed by specific countries.

Figure 9a plots the time path of net government interest payments and deficits, in percent of GDP, for Sweden and the UK. Debt is always higher in Sweden than in the UK (where it did, however, reach 72 percent of GDP in 1971, before the start of the sample plotted). The crisis early in the 1990s triggered an increase in the government deficit in both countries, but much more strongly in Sweden - where, as shown in Figure 9b, unemployment rose from below 3 percent to the same 10 percent observed in the UK, and employment declined by about the same amount from more than 70 percent. 
Figures 10c and 10d illustrate how these developments may be traced to the dynamics of labor market policy indicators. Unemployment insurance generosity, labor taxation and active labor market policies are always higher in Sweden than in the UK (where they decline steadily over the observation period). In Sweden, generous unemployment insurance and a decline in labor taxes appear to have contributed to debt accumulation in the crisis, and the subsequent decline of both of these indicators and (especially) of active labor market policies expenditure play a role, alongside the cyclical upswing, in the decline of public debt in the latter part of the period.

Moreover, Figure 9e shows that this response, while certainly well advised, was not without cost in terms of the wage inequality that labor market policies are meant to keep under control. In response to debt burden, the United Kingdom achieved low unemployment and high employment by accepting higher wage inequality in the 1980s. Sweden followed a similar path (around its different labor market configuration parameters) during the 1990s.

\section{Implications for future policy and research}

In the Swedish and UK experience, reform trends and their implications for inequality were arguably accelerated in the aftermath of debt accumulation triggered by the public deficit effects of cyclical crises. Other countries with different traditions chose yet other reform paths in response to their own macroeconomic and public finance problems. Italy, for example, relied not only on partial flexibility measures but also on coordinated wage bargaining in order to stabilize debt dynamics on the path to EMU membership. While sources of labor market and public debt problems differ across countries and periods in ways that make it difficult to obtain clear empirical results, the mechanism that links the two should always and everywhere be similar. Fiscal and non-fiscal policy instruments aimed at shaping labor market outcomes are constrained by public funding difficulties. The use of fiscal instruments to shape employment and unemployment may not only worsen public deficits, but also decrease employment and production in ways that endanger public debt sustainability.

In the 1970s and 1980s, labor market problems translated into public finance problems in countries where policymakers attempted to reduce the 
unemployment induced by wage hikes through measures such as early retirement and public employment policies. Such attempts were misguided in that structural labor market problems should be addressed by structural policies, aimed at reconciling the "security", "efficiency" and "fiscal" horns of the policy trilemma outlined in Section 2. Theory and past evidence are relevant for the possible consequences of the 2008-09 crisis, triggered perhaps by energy prices but certainly by financial market shocks, like the Swedish and Finnish crises of the 1990s, rather than by labor market problems as was the case in other European countries in the 1970s.

Since 2007, public debt/GDP ratios have increased by 75 percent in countries that experienced systemic financial crisis, and by an average of 20 percent in other countries (Reinhart and Rogoff, 2010). There are large differences across countries in the severity of the crisis and the intensity of fiscal responses, and the financial character of macroeconomic trouble while close to that of Sweden's experience in the 1990s - is not the same as that of debt accumulation in the 1970s in most developed countries, which was rooted in factor price hikes. In all countries and regardless of the source of macroeconomic problems, however, the need to service and stabilize debt will undoubtedly force policymakers to revise their priorities in the labor market as well as in other policy fields. Declines in employment and increases in unemployment occur late in the crisis, and are certainly more socially and politically costly than the preceding crashes in asset prices, as well as in production and profits. The extent to which the immediate relief of cyclical unemployment afforded by aggregate demand stimulation should be traded off against other policy objectives depends on individual countries' characteristics and political objectives. In all countries, however, policy responses to all aspects of the crisis can engender persistent future problems, because fiscal and monetary reactions to the crisis bequeath large public debt and looming inflation expectations to future policymakers.

In the aftermath of the crisis, it will not be easy to absorb the inherited emergency without hampering labor market performance. Should expected and actual inflation materialize in the aftermath of the crisis, we may again witness the same labor market mechanics as were observed in the early 1980s (Dornbusch, 1989), whereby debt stabilization would increase unemployment in the presence of rigid inflation expectations. To the extent that international economic integration and supranational constraints will continue to shape fiscal and monetary policies, however, structural reform reac- 
tions will more likely be responses to debt sustainability problems, at least in Europe (Bean, 1998; Belke, Herz and Vogel, 2007). As pointed out in Honohan's (1989) discussion of Dornbusch (1989), Ireland's failed stabilization in the early 1980s was due to that country's decision to increase the generosity of its unemployment insurance subsidies "in an attempt to shelter the worst off from the fiscal adjustment" and to its failure to implement real wage rate reductions in the public service sector. As debt accumulation will eventually force speedier labor market deregulation in integrated economies, the theoretical considerations and examination of past empirical patterns in this paper (as well as Ireland's more recent and likely future experience) suggest that policymakers should exercise discretionary budget policy more cautiously if they do not like the ultimate implications of debt accumulation for other policies' ability to shape labor market outcomes.

As for future research, the debt accumulation and decumulation patterns treated in this paper as a forcible variable for labor market policies are, of course, themselves endogenous to policy choices. The dynamics of debt accumulation and decumulation reflect policymakers' choices between large swings, aimed at macroeconomic stabilization in the face of exogenous shocks, and some degree of reversion intended to smooth primary fiscal balances. These policy choices presumably reflect the balance of a variety of different objectives and constraints, and certainly have different implications for intergenerational distribution. Over time and across countries, factors other than labor market policies shape both unemployment and debt dynamics. In the late $20^{\text {th }}$ century, the public debts of developed countries were rooted in policies that were chosen in response, among other things, to poor labor markets' performance. Hence, public debt service is certainly not completely suitable for purposes of assessing the sources and consequences of labor market policy choices, along the lines of Bertola and Lo Prete's (2010) analysis of globalization trends and country characteristics as drivers of policies relevant to financial development. In future work, it would be interesting to model labor market and public finance policy decisions jointly, possibly on the basis of welfare optimization and distortion minimization criteria for debt management, in an incomplete-markets environment (Missale, 1999; Faraglia, Marcet and Scott, 2008).

Such efforts may be worthwhile because, as this paper has shown, public debt and public finance dynamics do prove to be strongly associated empirically with changes in labor market policies and outcomes. Data scarcity 
makes it impossible to estimate more detailed and robust patterns of results, because government policies and deficits reflect a large variety of circumstances - some politically determined, and some determined outside the country, such as variation in global interest rates or, perhaps, the constraints of the Stability and Growth Pact. Still, the relevance of the institutional and political characteristics captured by welfare state groupings of countries indicates that politico-economic interactions may well be relevant, and that the policy implications of financial market incompleteness should take labor income distribution issues into account. 


\section{Data appendix}

Cross-country comparable long time series for public finance indicators are available from the OECD Employment Outlook data base (other sources do not cover periods before 1990) for all or most of the 1980-2003 period for the following countries: Australia, Austria, Belgium, Canada, Denmark, Finland, France, Germany, Ireland, Italy, Japan, the Netherlands, New Zealand, Norway, Portugal (only since 1995), Spain (only since 1987), Sweden, Switzerland, United Kingdom and United States. Labor market indicators are drawn from various other OECD databases (see below) for the same countries. Greece, in the news at the time of writing for its poor deficitreporting practices, is excluded from the sample by unavailability of both public finance and labor market policy indicators.

Figures and summary statistics tables use the periods 1970-1974 and 1975-1979 where available. For most countries and labor market policy indicators, however, only most years since 1980 are available. Five-year averages of those data are the units of observation in all regressions. The last period is the average of 2000-03.

\section{Public finance indicator definitions:}

- Public debt is measured as "General government gross financial liabilities": the debt and other liabilities (short and long-term) of all the institutions in the general government sector, defined by ESA95/SNA93, subject to data availability. For the United States, Flow of Funds estimates are used, which value debt at face value. The gross data are consolidated within and between the sub-sectors of the general government sector, national sources permitting.

- Public debt (net) is measured as "General government net financial liabilities": the gross financial liabilities of the general government sector less the financial assets of the general government sector. Such assets may be cash, bank deposits, loans to the private sector, participation in private sector companies, holdings in public corporations or foreign exchange reserves, depending on the institutional structure of the country concerned and data availability. With respect to Japan, data have recently been revised back to 1980 in 
a retroactive application of the current benchmark of 2000 prices. The revisions affect data prior to 1997.

- Public interest payments are defined as "General government net debt interest payments" and Public interest payments (net) a "General government net debt interest payments."

- Government deficit is measured as "Government net lending:" general government current tax and non-tax receipts less general government total outlays.

- See [http://www.oecd.org/document/25/0,3343,en_2649_34109_ 33702745_1_1_1_1,00.html] for further details on definitions and cross-country comparability issues.

Labor market policy indicators:

- Labor tax rate is measured as the "Total tax wedge (average rate in $\%$ ), single at $100 \%$ of average earnings, no child" available for the period 1979-2003 (with some missing values) from the OECD, Taxing Wages 2007.

- Unemployment insurance generosity is the OECD summary measure of benefit entitlements, available for the period 1961-2005 from OECD, Tax-Benefit Models, [www.oecd.org/els/social/workincentives].

- Active labor market policies refer to the percent ratio of spending per unemployed person to GDP per capita, taken from the Bassanini and Duval (2006) dataset.

Labor market performance indicators:

- Unemployment rate of working age (15-64) population, from the Bassanini and Duval (2006) dataset.

- Employment rate of working age population, computed from OECD Economic Outlook data.

- Wage inequality is measured in terms of ratios of median wage to the 10th percentile of the wage distribution, and of its 90th percentile to the 10th percentile, from the OECD Trends in Earnings Dispersion database. 


\section{References}

Alesina, A. and Perotti, R. (1996), Reducing budget deficits, Swedish Economic Policy Review 3, 113-138.

Andersen, T.M. and Rose Skaksen, J. (2007), Labour demand, wage mark-ups, and product market integration, Journal of Economics 92, 103-135.

Bacchiocchi, E., Borghi, E. and Missale, A. (2009), Public investment under fiscal constraints, Working Paper DEAS, Università di Milano.

Bassanini, A. and Duval, R. (2006), Employment patterns in OECD countries: Reassessing the role of policies and institutions, OECD Economics Department Working Paper 486; OECD Social, Employment and Migration Working Paper, Paris.

Bean, C. (1998), The interaction of aggregate demand policies and labour market reform, Swedish Economic Policy Review 5, 353-382.

Belke, A., Herz, B. and Vogel, L. (2007), Reforms, exchange rates and monetary commitment: A panel analysis for OECD countries, Open Economies Review 18, 369-388.

Bertola, G. (2006), Social and labour market policies in a growing EU, Swedish Economic Policy Review 13, 189-232.

Bertola, G. (2009), Labor market regulation: Motives, measures, effects, Conditions of Work and Employment Series 21, International Labor Office, Geneva.

Bertola, G. and Lo Prete, A. (2010), Whence policy? Government policies, finance, and economic integration, CEPR Discussion Paper 7820.

Daveri, F. and Tabellini, G. (2000), Unemployment, growth and taxation in industrial countries, Economic Policy 15, 47-104.

Disney, R. (2004), Are contributions to public pension programmes a tax on employment?, Economic Policy 39, 267-311.

Dornbusch, R. (1989), Credibility, debt and unemployment: Ireland's failed stabilization, Economic Policy 4, 174-201.

Esping-Andersen, G. (1999), Social Foundations of Post-industrial Economies, Oxford University Press, Oxford.

Faraglia, E., Marcet, A. and Scott, A. (2008), Fiscal insurance and debt management in OECD economies, Economic Journal 118, 363-386.

Galì, J. and Perotti, R. (2003), Fiscal policy and monetary integration in Europe, Economic Policy 18, pp. 533-572.

Giannitsarou, C. and Scott, A. (2006), Inflation implications of rising government debt, NBER International Seminar on Macroeconomics 2006, 393-442.

Guichard, S., Kennedy, M., Wurzel, E. and André, C. (2007), What promotes fiscal consolidation: OECD country experiences, OECD Economics Department Working Papers 553, Paris.

Hauptmeier, S., Heipertz, M. and Schuknecht, L. (2007), Expenditure reform in industrialised countries: A case study approach, Fiscal Studies 28, 293-342.

Honohan, P. (1989), Comment on Dornbusch, Economic Policy 4, 202-205.

Missale, A. (1999), Public Debt Management, Oxford University Press, Oxford.

Pissarides, C. A. (1998), The impact of employment tax cuts on unemployment and wages: The role of unemployment benefits and tax structure, European Economic Review 42, 155-183. 
Reinhart, C.M. and Rogoff, K.S. (2010), Growth in a time of debt, NBER Working Paper 15639.

Tagkalakis, A. (2009), Fiscal adjustments: Do labor and product market institutions matter, Public Choice 139, 389-411.

Tullio, G. (1987), Long run implications of the increase in taxation and public debt for employment and economic growth in Europe, European Economic Review 31, 741-80. 
Table 1. Labor market policies and wage inequality in different groups of countries

\begin{tabular}{lrrrr}
\hline & $\begin{array}{c}\text { Unempl. } \\
\text { insurance } \\
\text { generosity }\end{array}$ & Labor tax rate & $\begin{array}{r}\text { Active Labor } \\
\text { Market Policy } \\
\text { (a) }\end{array}$ & $\begin{array}{r}\text { Wage } \\
\text { inequality (b) }\end{array}$ \\
\hline Nordic & 33.6 & 45.1 & 52.5 & 2.2 \\
Anglo-Saxon & 18.8 & 30.9 & 12.0 & 3.8 \\
Continental & 37.7 & 47.7 & 33.5 & 2.9 \\
Mediterranean & 21.5 & 41.6 & 11.4 & 2.9 \\
\hline
\end{tabular}

Note: Nordic: Denmark, Finland, Norway, Sweden; Anglo-Saxon: Australia, Canada, Ireland, United Kingdom, United States; Continental: Austria, Belgium, France, Germany, Netherlands; Mediterranean: Italy, Portugal, Spain. (a) Expenditure per unemployed person as percent of per capita GDP. (b) Ratio of 90th to 10th percentile.

Table 2. Level and variability of unemployment and employment in different groups of countries

\begin{tabular}{lcccc}
\hline & \multicolumn{2}{c}{ Unemployment rate } & \multicolumn{2}{c}{ Employment rate } \\
\hline & mean & Std. dev. & mean & std. dev. \\
Nordic & 5.4 & 3.4 & 71.1 & 4.9 \\
Anglo-Saxon & 7.2 & 2.3 & 66.2 & 4.5 \\
Continental & 6.5 & 3.4 & 65.4 & 5.0 \\
Mediterranean & 11.2 & 5.2 & 56.6 & 6.6 \\
\hline
\end{tabular}

Note: Country group definitions as in Table 1.

Table 3. Regressions of unemployment rates on labor market policy indicators

\begin{tabular}{|c|c|c|c|c|c|c|}
\hline \multicolumn{7}{|c|}{ Regressions: Unemployment rate } \\
\hline $\begin{array}{l}\text { Unemployment insurance } \\
\text { generosity }\end{array}$ & $\begin{array}{r}0.013 \\
0.47\end{array}$ & & & $\begin{array}{r}0.036 \\
1.22\end{array}$ & $\begin{array}{r}0.058 \\
1.42\end{array}$ & $\begin{array}{r}0.050 \\
1.37\end{array}$ \\
\hline Labor tax rate & & $\begin{array}{r}0.113 \\
3.92\end{array}$ & & $\begin{array}{r}0.151 \\
5.79\end{array}$ & $\begin{array}{r}0.269 \\
2.60\end{array}$ & $\begin{array}{r}0.217 \\
1.86\end{array}$ \\
\hline $\begin{array}{l}\text { Active labor market } \\
\text { policies }\end{array}$ & & & $\begin{array}{r}-0.055 \\
-4.35\end{array}$ & $\begin{array}{r}-0.080 \\
-4.10\end{array}$ & $\begin{array}{r}-0.057 \\
-4.61\end{array}$ & $\begin{array}{r}-0.055 \\
-4.49\end{array}$ \\
\hline Country effects & No & No & No & No & Yes & Yes \\
\hline Period effects & No & No & No & No & No & Yes \\
\hline $\mathrm{R}^{2}$ & 0.002 & 0.089 & 0.143 & 0.331 & 0.871 & 0.899 \\
\hline $\mathrm{N}$ & 70 & 70 & 70 & 70 & 70 & 70 \\
\hline
\end{tabular}

Notes: Observations are averages of yearly data for the countries and periods listed in the Data Appendix. All regressions include a constant (not shown); t-statistics based on robust standard errors in italics below the coefficients. 
Table 4. Regressions of employment rate on labor market policy indicators

\begin{tabular}{lrrrrrr}
\hline Regressions: Employment rate & & & & & & \\
\hline Unemp. insurance generosity & 0.099 & & & 0.110 & -0.108 & -0.146 \\
& 1.53 & & & 1.71 & -1.87 & -2.91 \\
Labor tax rate & & -0.226 & & -0.374 & -0.201 & -0.092 \\
& & -2.50 & & -4.16 & -1.35 & -0.76 \\
Active labor market policies & & & 0.104 & 0.119 & 0.091 & 0.092 \\
& & & 2.96 & 3.25 & 5.05 & 7.44 \\
Country effects & No & No & No & No & Yes & Yes \\
Period effects & No & No & No & No & No & Yes \\
\hline $\mathrm{R}^{2}$ & 0.030 & 0.084 & 0.122 & 0.312 & 0.944 & 0.966 \\
$\mathrm{~N}$ & 70 & 70 & 70 & 70 & 70 & 70 \\
\hline
\end{tabular}

Notes: Observations are averages of yearly data for the countries and periods listed in the Data Appendix. All regressions include a constant (not shown); t-statistics based on robust standard errors in italics below the coefficients.

Table 5. Unemployment and employment at different public debt/GDP ratios. Yearly data.

\begin{tabular}{rcccc}
\hline $\begin{array}{c}\text { Public } \\
\text { Debt/GDP }\end{array}$ & \multicolumn{2}{c}{ Unemployment rate } & \multicolumn{2}{c}{ Employment rate } \\
& mean & std. dev. & mean & std. dev. \\
\hline $0-30 \%$ & 4.1 & 2.4 & 69.9 & 2.8 \\
$30-60 \%$ & 5.9 & 3.5 & 67.7 & 6.8 \\
$60-90 \%$ & 7.5 & 4.3 & 66.3 & 6.7 \\
$90-120 \%$ & 9.0 & 2.6 & 61.7 & 7.1 \\
$>120 \%$ & 9.0 & 2.4 & 59.6 & 7.9 \\
\hline
\end{tabular}

Table 6. Regressions of unemployment rate on public finance indicators

\begin{tabular}{lrrrr}
\hline Regressions: Unemployment rate & & & & \\
\hline Public debt & 0.026 & 0.087 & 0.182 & 0.204 \\
& 2.10 & 1.64 & 3.93 & 3.81 \\
Public debt squared /100 & & -0.038 & -0.066 & -0.070 \\
& No & -1.16 & -2.94 & -2.65 \\
Country effects & No & No & Yes & Yes \\
Period effects & 0.037 & 0.047 & No & Yes \\
\hline $\mathrm{R}^{2}$ & 70 & 70 & 70 & 0.901 \\
$\mathrm{~N}$ & & & & 70 \\
\hline
\end{tabular}




\begin{tabular}{|c|c|c|c|c|}
\hline Regressions: Unemployment rate & & & & \\
\hline Public debt (net) & $\begin{array}{r}0.029 \\
3.50\end{array}$ & $\begin{array}{r}0.028 \\
2.54\end{array}$ & $\begin{array}{r}0.043 \\
2.26\end{array}$ & $\begin{array}{r}0.027 \\
1.21\end{array}$ \\
\hline Public debt (net) squared /100 & & $\begin{array}{r}0.001 \\
0.13\end{array}$ & $\begin{array}{r}0.006 \\
0.43\end{array}$ & $\begin{array}{r}0.019 \\
0.83\end{array}$ \\
\hline Country effects & No & No & Yes & Yes \\
\hline Period effects & No & No & No & Yes \\
\hline $\begin{array}{l}\mathrm{R}^{2} \\
\mathrm{~N}\end{array}$ & $\begin{array}{r}0.081 \\
67\end{array}$ & $\begin{array}{r}0.081 \\
67\end{array}$ & $\begin{array}{r}0.800 \\
67\end{array}$ & $\begin{array}{r}0.839 \\
67\end{array}$ \\
\hline \multicolumn{5}{|l|}{ Regressions: Unemployment rate } \\
\hline Public interest payments & $\begin{array}{r}0.544 \\
5.34\end{array}$ & $\begin{array}{r}1.370 \\
2.39\end{array}$ & $\begin{array}{r}2.323 \\
3.77\end{array}$ & $\begin{array}{r}2.613 \\
3.67\end{array}$ \\
\hline Public interest payments, squared & & $\begin{array}{r}-0.070 \\
-1.46\end{array}$ & $\begin{array}{r}-0.114 \\
-2.91\end{array}$ & $\begin{array}{r}-0.129 \\
-3.04\end{array}$ \\
\hline Country effects & No & No & Yes & Yes \\
\hline Period effects & No & No & No & Yes \\
\hline $\mathrm{R}^{2}$ & 0.117 & 0.131 & 0.878 & 0.886 \\
\hline $\mathrm{N}$ & 70 & 70 & 70 & 70 \\
\hline \multicolumn{5}{|l|}{ Regressions: Unemployment rate } \\
\hline Public interest payments (net) & $\begin{array}{r}0.554 \\
5.51\end{array}$ & $\begin{array}{r}0.743 \\
3.04\end{array}$ & $\begin{array}{r}1.846 \\
3.38\end{array}$ & $\begin{array}{r}1.744 \\
3.08\end{array}$ \\
\hline Public interest payments (net), squared & & $\begin{array}{r}-0.024 \\
-0.96\end{array}$ & $\begin{array}{r}-0.085 \\
-2.23\end{array}$ & $\begin{array}{r}-0.097 \\
-2.58\end{array}$ \\
\hline Country effects & No & No & Yes & Yes \\
\hline Period effects & No & No & No & Yes \\
\hline $\mathrm{R}^{2}$ & 0.157 & 0.163 & 0.865 & 0.877 \\
\hline $\mathrm{N}$ & 70 & 70 & 70 & 70 \\
\hline
\end{tabular}

Notes: Observations are period averages of yearly data for the countries and periods listed in the Data Appendix. All regressions include a constant (not shown); t-statistics based on robust standard errors in italics below the coefficients. 
Table 7. Regressions of employment rate on public finance indicators

\begin{tabular}{|c|c|c|c|c|}
\hline Regressions: Employment rate & & & & \\
\hline Public debt & $\begin{array}{r}-0.100 \\
-2.85\end{array}$ & $\begin{array}{r}-0.152 \\
-1.04\end{array}$ & $\begin{array}{r}-0.183 \\
-2.24\end{array}$ & $\begin{array}{r}-0.217 \\
-2.43\end{array}$ \\
\hline Public debt, squared/100 & & $\begin{array}{r}0.032 \\
0.32\end{array}$ & $\begin{array}{r}0.076 \\
1.80\end{array}$ & $\begin{array}{r}0.081 \\
1.92\end{array}$ \\
\hline Country effects & No & No & Yes & Yes \\
\hline Period effects & No & No & No & Yes \\
\hline $\mathrm{R}^{2}$ & 0.126 & 0.128 & 0.922 & 0.951 \\
\hline \multicolumn{5}{|l|}{ Regressions: Employment rate } \\
\hline Public debt (net) & $\begin{array}{r}-0.106 \\
-7.33\end{array}$ & $\begin{array}{r}-0.088 \\
-4.84\end{array}$ & $\begin{array}{r}-0.039 \\
-1.56\end{array}$ & $\begin{array}{r}-0.015 \\
-0.69\end{array}$ \\
\hline Public debt (net), squared/100 & & $\begin{array}{r}-0.033 \\
-1.50\end{array}$ & $\begin{array}{r}0.009 \\
0.42\end{array}$ & $\begin{array}{r}-0.011 \\
-0.43\end{array}$ \\
\hline Country effects & No & No & Yes & Yes \\
\hline Period effects & No & No & No & Yes \\
\hline $\mathrm{R}^{2}$ & 0.293 & 0.304 & 0.898 & 0.928 \\
\hline $\mathrm{N}$ & 67 & 67 & 67 & 67 \\
\hline \multicolumn{5}{|l|}{ Regressions: Employment rate } \\
\hline Public interest payments & $\begin{array}{l}-1.429 \\
-4.23\end{array}$ & $\begin{array}{l}-2.764 \\
-1.83\end{array}$ & $\begin{array}{l}-2.933 \\
-3.32\end{array}$ & $\begin{array}{l}-2.485 \\
-2.06\end{array}$ \\
\hline Public interest payments, squared & & $\begin{array}{l}0.113 \\
0.95\end{array}$ & $\begin{array}{l}0.137 \\
2.63\end{array}$ & $\begin{array}{l}0.125 \\
1.89\end{array}$ \\
\hline Country effects & No & No & Yes & Yes \\
\hline Period effects & No & No & No & Yes \\
\hline $\mathrm{R}^{2}$ & 0.191 & 0.200 & 0.945 & 0.947 \\
\hline $\mathrm{N}$ & 70 & 70 & 70 & 70 \\
\hline
\end{tabular}




\begin{tabular}{lllll}
\hline \multicolumn{2}{l}{ Regressions: Employment rate } & & & \\
\hline Public interest payments (net) & -1.587 & -1.429 & -1.923 & -1.631 \\
& -7.53 & -3.29 & -2.35 & -1.84 \\
Public interest payments (net), & & -0.020 & 0.071 & 0.090 \\
squared & & -0.49 & 1.31 & 1.62 \\
& No & No & Yes & Yes \\
Country effects & No & No & No & Yes \\
Period effects & 0.306 & 0.307 & 0.933 & 0.945 \\
$\mathrm{R}^{2}$ & 70 & 70 & 70 & 70 \\
$\mathrm{~N}$ & & & & \\
\hline
\end{tabular}

Notes: Observations are period averages of yearly data for the countries and periods listed in the Data Appendix. All regressions include a constant (not shown); t-statistics based on robust standard errors in italics below the coefcients.

Table 8. Regressions of changes in public debt service on levels of public debt service

Regressions: Change in public interest payments (net)

\begin{tabular}{lrrrrrrr} 
& & \multicolumn{2}{c}{ Labor tax rate } & \multicolumn{2}{c}{$\begin{array}{c}\text { Unemployment } \\
\text { ins. generosity }\end{array}$} & \multicolumn{2}{c}{$\begin{array}{c}\text { Active labor } \\
\text { market policies }\end{array}$} \\
& & Low & High & Low & High & Low & High \\
Public interest & & & & & & & \\
payments (net) & -0.149 & -0.085 & -0.188 & -0.021 & -0.219 & -0.079 & -0.202 \\
& -2.61 & -0.94 & -2.59 & -0.19 & -3.57 & -0.82 & -2.95 \\
\hline $\mathrm{R}^{2}$ & 0.124 & 0.047 & 0.193 & 0.002 & 0.329 & 0.028 & 0.275 \\
$\mathrm{~N}$ & 50 & 20 & 30 & 22 & 28 & 25 & 25 \\
\hline
\end{tabular}

Note: Observations are period averages of yearly data for the countries and periods listed in the Data Appendix. Except in the first column, the sample is split according to whether each labor market policy indicator is observed above ("High") or below ("Low") its country-specific median level. All regressions include a constant (not shown); $\mathrm{t}$-statistics based on robust standard errors in italics below the coefficients. 
Table 9. Regressions of unemployment insurance generosity on public finance and welfare state indicators

\begin{tabular}{|c|c|c|c|c|c|c|c|}
\hline \multicolumn{8}{|c|}{ Regressions: Unemployment insurance generosity } \\
\hline \multirow{2}{*}{$\begin{array}{l}\text { Public interest payments } \\
\text { (net) slope }\end{array}$} & -0.423 & -0.270 & -0.813 & -0.154 & -1.315 & -0.958 & -0.900 \\
\hline & -0.70 & -0.26 & -0.79 & -0.28 & -1.48 & -1.07 & -0.32 \\
\hline \multicolumn{8}{|l|}{$\begin{array}{l}\text { Welfare state regimes, } \\
\text { level effects: }\end{array}$} \\
\hline \multirow[t]{3}{*}{ Nordic } & & & & & 9.425 & 9.850 & \\
\hline & & & & 14.938 & & & \\
\hline & & & & 3.09 & 1.78 & 1.80 & \\
\hline \multirow[t]{3}{*}{ Anglo-Saxon } & & & & - & - & - & \\
\hline & & & & 3.860 & 1.043 & 2.139 & \\
\hline & & & & -1.07 & -0.19 & -0.37 & \\
\hline \multirow[t]{3}{*}{ Continental } & & & & & 5.521 & 5.028 & \\
\hline & & & & 15.166 & & & \\
\hline & & & & 3.69 & 0.89 & 0.79 & \\
\hline \multicolumn{8}{|l|}{ Slope effects: } \\
\hline \multirow[t]{2}{*}{ Nordic } & & & & & 2.639 & 2.267 & 0.060 \\
\hline & & & & & 2.08 & 1.69 & 0.02 \\
\hline \multirow[t]{3}{*}{ Anglo-Saxon } & & & & & - & - & 1.693 \\
\hline & & & & & 1.567 & 1.484 & \\
\hline & & & & & -1.27 & -1.06 & 0.60 \\
\hline \multirow[t]{2}{*}{ Continental } & & & & & 2.423 & 2.226 & 1.470 \\
\hline & & & & & 2.33 & 2.08 & 0.53 \\
\hline Country effects & No & Yes & Yes & No & No & No & Yes \\
\hline Period effects & No & No & Yes & No & No & Yes & No \\
\hline $\mathrm{R}^{2}$ & 0.007 & 0.914 & 0.937 & 0.415 & 0.479 & 0.524 & 0.916 \\
\hline$N$ & 70 & 70 & 70 & 70 & 70 & 70 & 70 \\
\hline
\end{tabular}

Notes: Country group definitions as in Table 1. Observations are period averages of yearly data for the countries and periods listed in the Data Appendix. All regressions include a constant (not shown); t-statistics based on robust standard errors in italics below the coefficients. 
Table 10. Regressions of labor tax rate on public finance and welfare state indicators

\begin{tabular}{|c|c|c|c|c|c|c|c|}
\hline Regressions: Labor tax rate & & & & & & & \\
\hline \multirow{2}{*}{$\begin{array}{l}\text { Public interest payments } \\
\text { (net) slope }\end{array}$} & 1.511 & 0.605 & 0.600 & 1.985 & 2.906 & 2.841 & 0.441 \\
\hline & 3.70 & 2.28 & 1.86 & 8.63 & 6.47 & 7.12 & 1.58 \\
\hline \multicolumn{8}{|l|}{$\begin{array}{l}\text { Welfare state regimes, } \\
\text { level effects: }\end{array}$} \\
\hline Nordic & & & & $\begin{array}{r}15.546 \\
9.19\end{array}$ & $\begin{array}{r}19.658 \\
8.58\end{array}$ & $\begin{array}{r}19.895 \\
8.53\end{array}$ & \\
\hline Anglo-Saxon & & & & $\begin{array}{r}-4.034 \\
-2.65\end{array}$ & $\begin{array}{r}-0.775 \\
-0.28\end{array}$ & $\begin{array}{r}-1.365 \\
-0.51\end{array}$ & \\
\hline Continental & & & & $\begin{array}{r}11.617 \\
7.72\end{array}$ & $\begin{array}{r}17.919 \\
6.16\end{array}$ & $\begin{array}{r}17.910 \\
6.15\end{array}$ & \\
\hline \multicolumn{8}{|l|}{ Slope effects: } \\
\hline Nordic & & & & & $\begin{array}{r}-1.756 \\
-3.00\end{array}$ & $\begin{array}{r}-1.687 \\
-3.06\end{array}$ & $\begin{array}{r}0.511 \\
1.29\end{array}$ \\
\hline Anglo-Saxon & & & & & $\begin{array}{r}-0.845 \\
-1.05\end{array}$ & $\begin{array}{r}-0.505 \\
-0.63\end{array}$ & $\begin{array}{r}0.646 \\
0.73\end{array}$ \\
\hline Continental & & & & & $\begin{array}{r}-1.600 \\
-2.82\end{array}$ & $\begin{array}{r}-1.477 \\
-2.78\end{array}$ & $\begin{array}{r}-0.156 \\
-0.20\end{array}$ \\
\hline Country effects & No & Yes & Yes & No & No & No & Yes \\
\hline Period effects & No & No & Yes & No & No & Yes & No \\
\hline $\mathrm{R}^{2}$ & 0.167 & 0.970 & 0.971 & 0.806 & 0.842 & 0.855 & 0.970 \\
\hline $\mathrm{N}$ & 70 & 70 & 70 & 70 & 70 & 70 & 70 \\
\hline
\end{tabular}

Notes: Country group definitions as in Table 1. Observations are period averages of yearly data for the countries and periods listed in the Data Appendix.

All regressions include a constant (not shown); t-statistics based on robust standard errors in italics below the coefficients. 
Table 11. Regressions of active labor market policies on public finance and welfare state indicators

\begin{tabular}{|c|c|c|c|c|c|c|c|}
\hline \multicolumn{8}{|c|}{ Regressions: Active labor market policies } \\
\hline Public interest & -2.415 & -4.454 & -5.653 & -1.237 & -2.114 & -1.882 & -1.058 \\
\hline & -2.14 & -2.35 & -2.82 & -1.73 & -4.08 & -3.24 & -1.04 \\
\hline \multicolumn{8}{|l|}{$\begin{array}{l}\text { Welfare state regimes, } \\
\text { level effects: }\end{array}$} \\
\hline Nordic & & & & $\begin{array}{l}31.448 \\
3.19\end{array}$ & $\begin{array}{l}25.888 \\
3.14\end{array}$ & $\begin{array}{c}26.097 \\
3.24\end{array}$ & \\
\hline Anglo-Saxon & & & & $\begin{array}{l}-2.049 \\
-0.56\end{array}$ & $\begin{array}{l}3.165 \\
0.32\end{array}$ & $\begin{array}{l}1.731 \\
0.17\end{array}$ & \\
\hline Continental & & & & $\begin{array}{c}20.025 \\
3.44\end{array}$ & $\begin{array}{c}17.614 \\
1.46\end{array}$ & $\begin{array}{c}17.616 \\
1.45\end{array}$ & \\
\hline \multicolumn{8}{|l|}{ Slope effects: } \\
\hline Nordic & & & & & $\begin{array}{l}3.777 \\
1.51\end{array}$ & $\begin{array}{l}3.628 \\
1.36\end{array}$ & $\begin{array}{l}-8.841 \\
-2.61\end{array}$ \\
\hline Anglo-Saxon & & & & & $\begin{array}{l}-2.358 \\
-0.89\end{array}$ & $\begin{array}{l}-1.973 \\
-0.72\end{array}$ & $\begin{array}{l}0.937 \\
0.86\end{array}$ \\
\hline Continental & & & & & $\begin{array}{l}0.667 \\
0.41\end{array}$ & $\begin{array}{l}0.521 \\
0.32\end{array}$ & $\begin{array}{l}-5.574 \\
-0.94\end{array}$ \\
\hline Country effects & No & Yes & Yes & No & No & No & Yes \\
\hline Period effects & No & No & Yes & No & No & Yes & No \\
\hline $\mathrm{R}^{2}$ & 0.063 & 0.734 & 0.743 & 0.338 & 0.364 & 0.372 & 0.754 \\
\hline $\mathrm{N}$ & 70 & 70 & 70 & 70 & 70 & 70 & 70 \\
\hline
\end{tabular}

Notes: Country group definitions as in Table 1. Observations are period averages of yearly data for the countries and periods listed in the Data Appendix. All regressions include a constant (not shown); t-statistics based on robust standard errors in italics below the coefficients. 

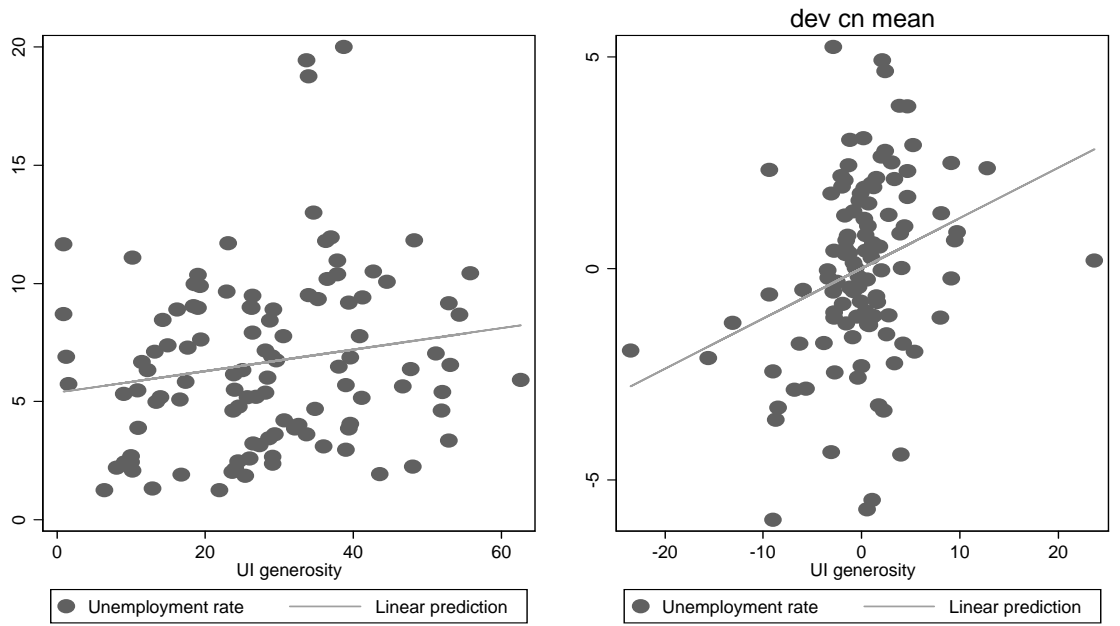

Figure 1. Unemployment rate and unemployment insurance generosity

Notes: The left-hand side panel plots 5-year averages for the countries and periods listed in the Data Appendix; the right-hand side panel plots deviations from country means of the same observations.
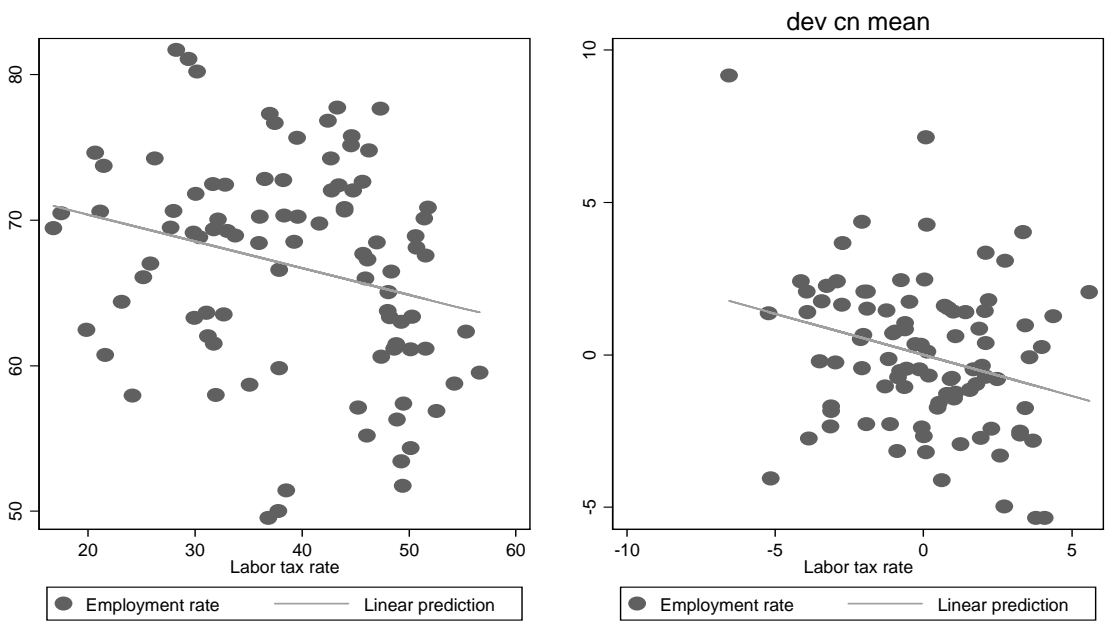

Figure 2. Employment rate and labor taxation

Notes: The left-hand side panel plots 5-year averages for the countries and periods listed in the Data Appendix; the right-hand side panel plots deviations from country means of the same observations. 


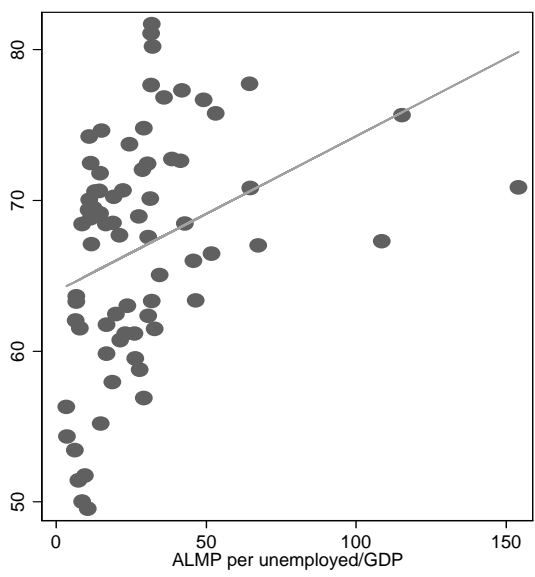

Employment rate

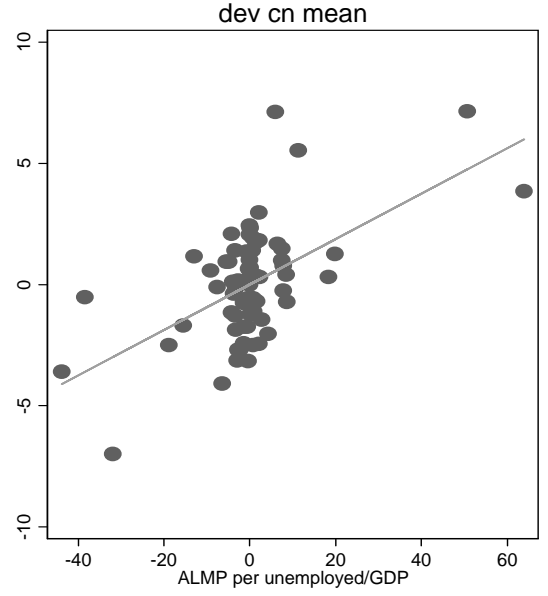

Employment rate Linear prediction

Figure 3. Unemployment rate and active labor market policies

Notes: The left-hand side panel plots 5-year averages for the countries and periods listed in the Data Appendix; the right-hand side panel plots deviations from country means of the same observations.
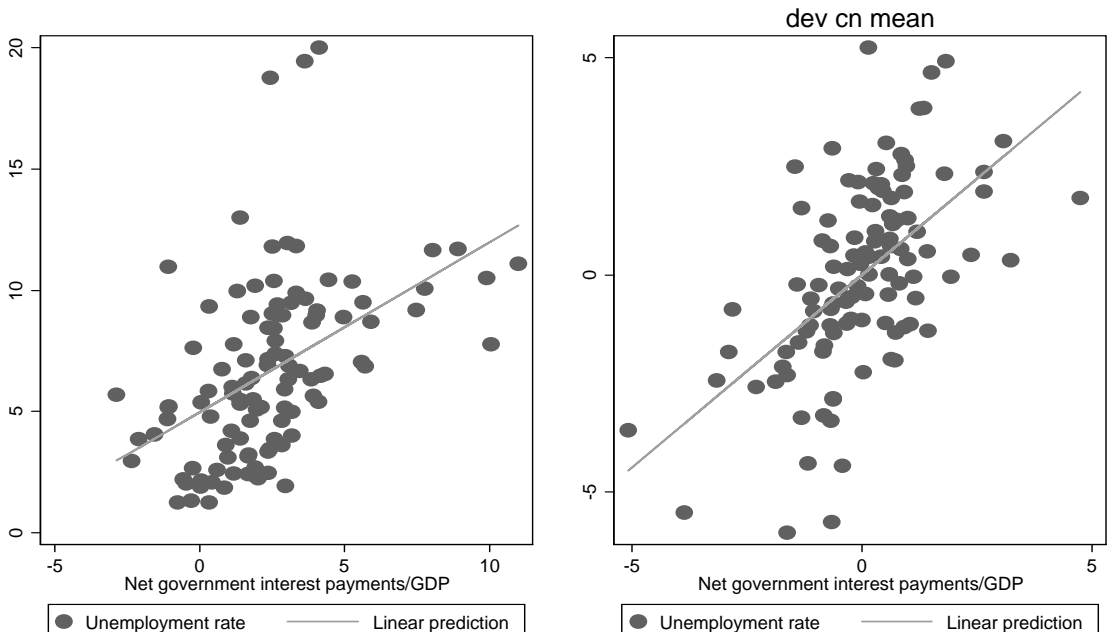

Figure 4. Public debt and unemployment

Notes: The left-hand side panel plots 5-year averages for the countries and periods listed in the Data Appendix; the righthand side panel plots deviations from country means of the same observations. 

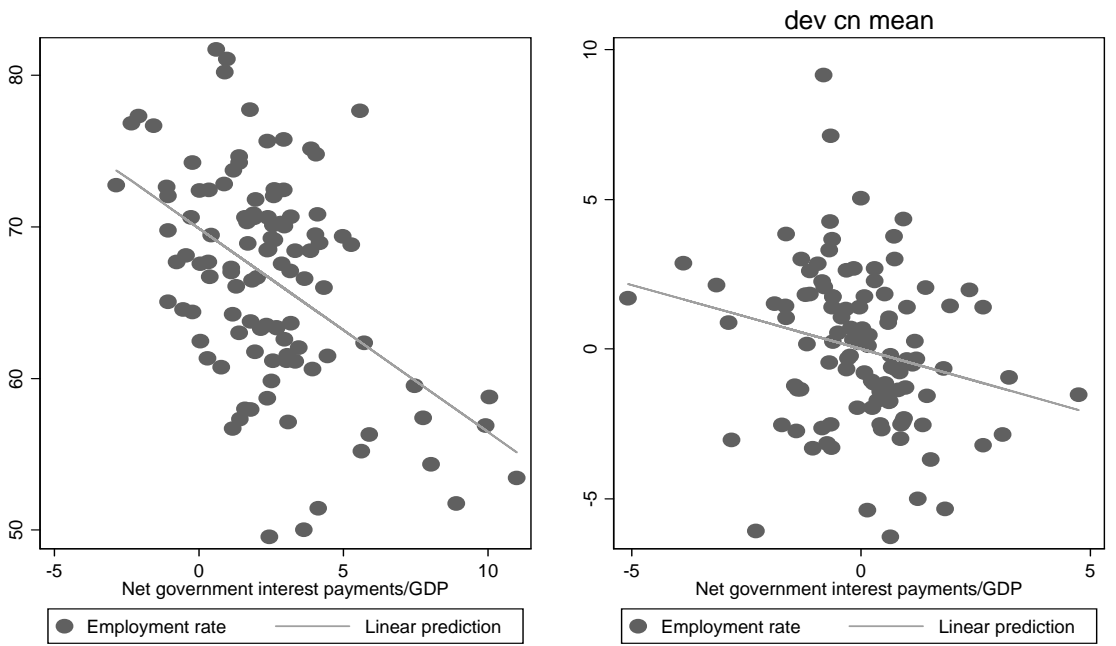

Figure 5. Public debt and employment

Notes: The left-hand side panel plots 5-year averages for the countries and periods listed in the Data Appendix; the righthand side panel plots deviations from country means of the same observations.
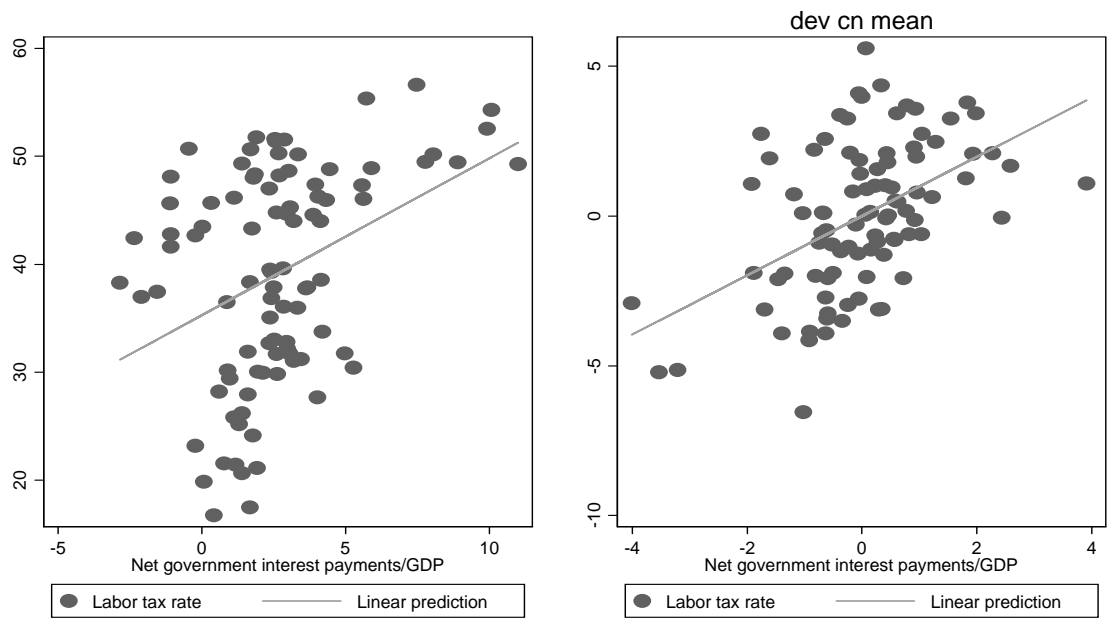

Figure 6. Public debt and labor taxation

Note: The left-hand side panel plots 5-year averages for the countries and periods listed in the Data Appendix; the righthand side panel plots deviations from country means of the same observations. 

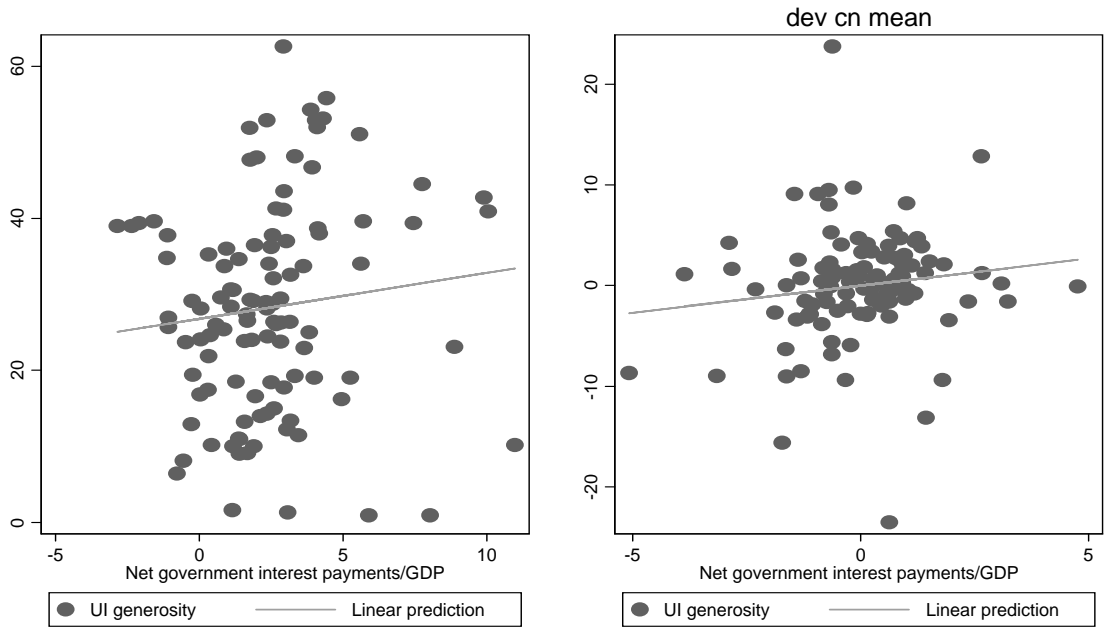

Figure 7. Public debt and unemployment insurance generosity

Notes: The left-hand side panel plots 5-year averages for the countries and periods listed in the Data Appendix; the right-hand side panel plots deviations from country means of the same observations.
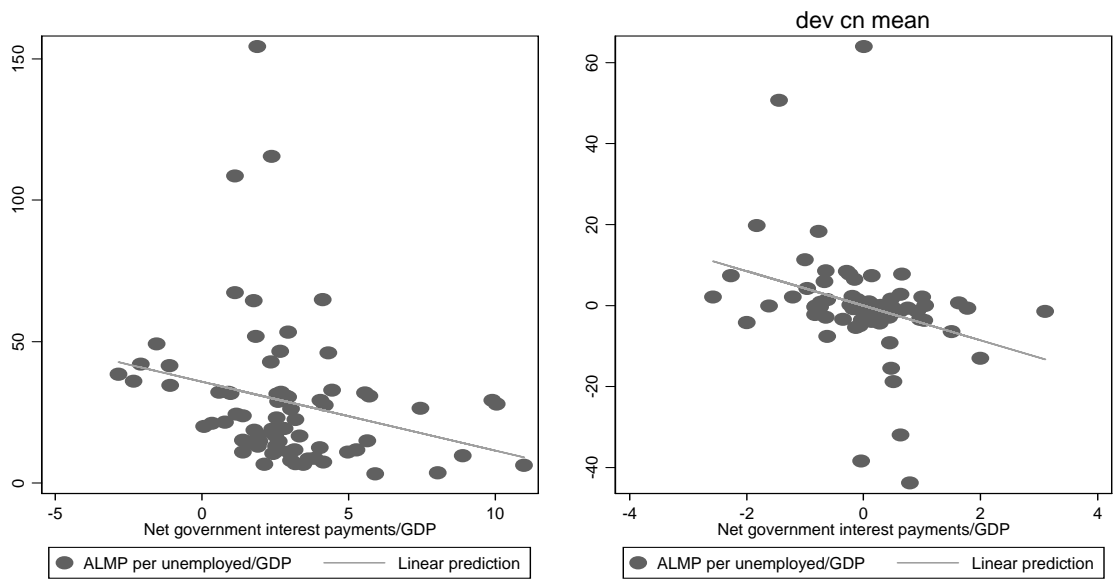

Figure 8. Public debt and active labor market policies

Note: The left-hand side panel plots 5-year averages for the countries and periods listed in the Data Appendix; the right-hand side panel plots deviations from country means of the same observations 


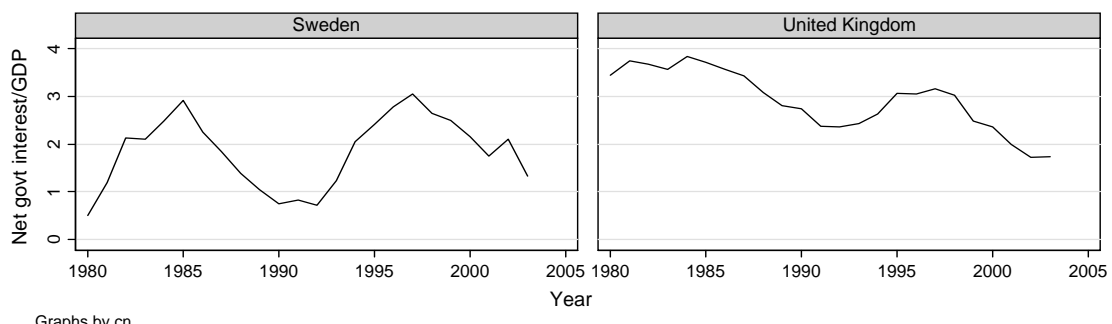

Graphs by cn

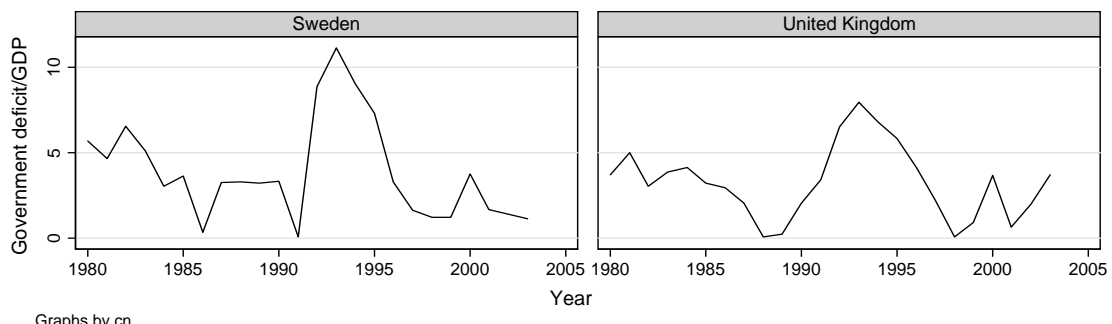

Graphs by cn

Figure 9a. Public debt and deficits in Sweden and in the UK
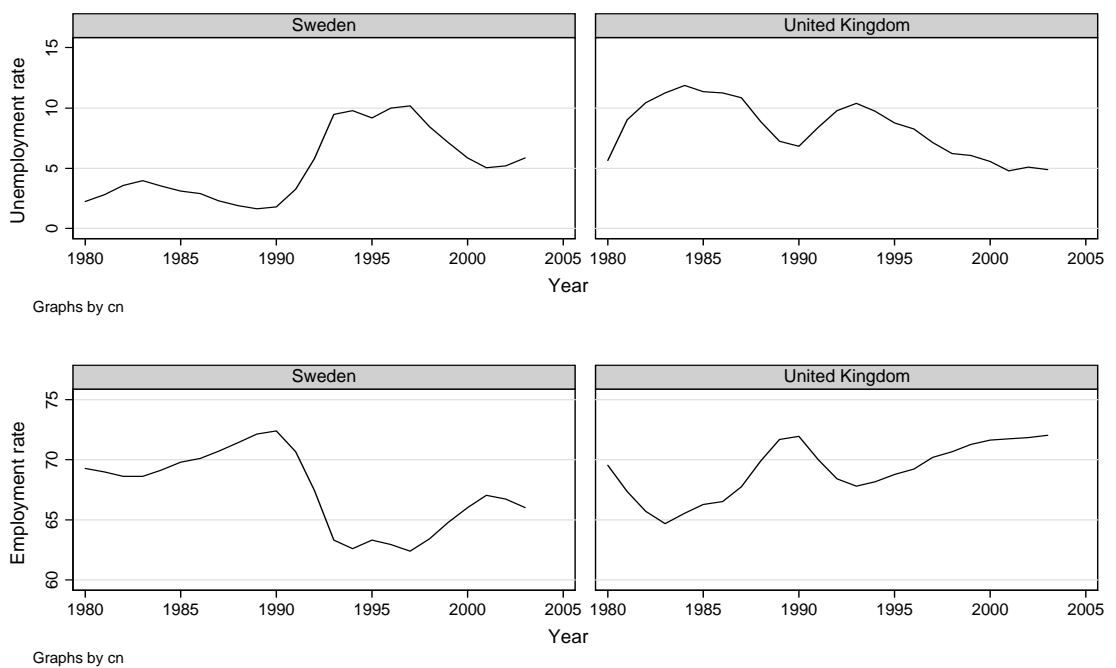

Figure 9b. Unemployment and employment rates in Sweden and in the UK 

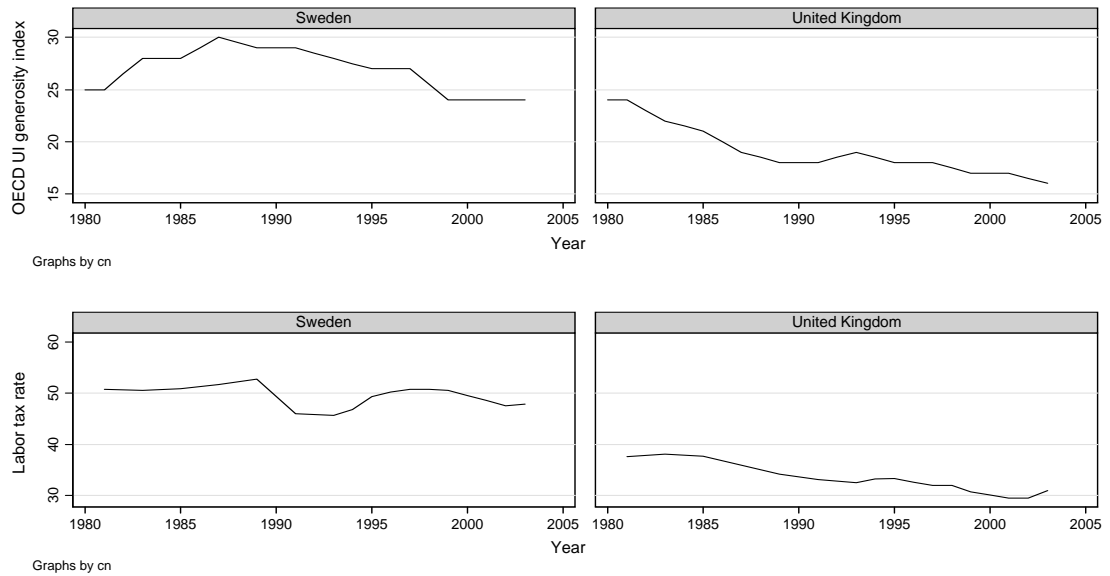

Graphs by $\mathrm{c}$

Figure 9c. Unemployment insurance generosity and labor taxes in Sweden and in the UK
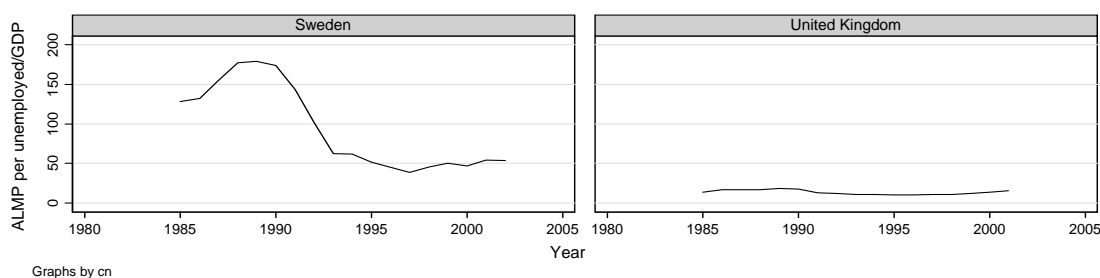

Graphs by cn

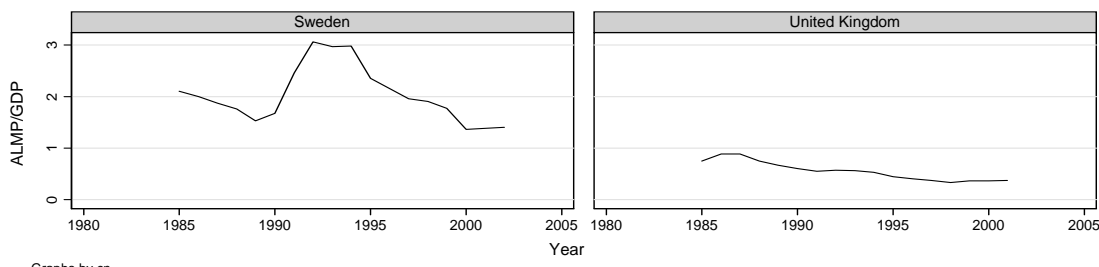

Figure 9d. Active labor market policy expenditures in Sweden and in the UK

Note: Top panel: per unemployed person as a percent fraction of per capita GDP; bottom panel: total as a percent of GDP. 

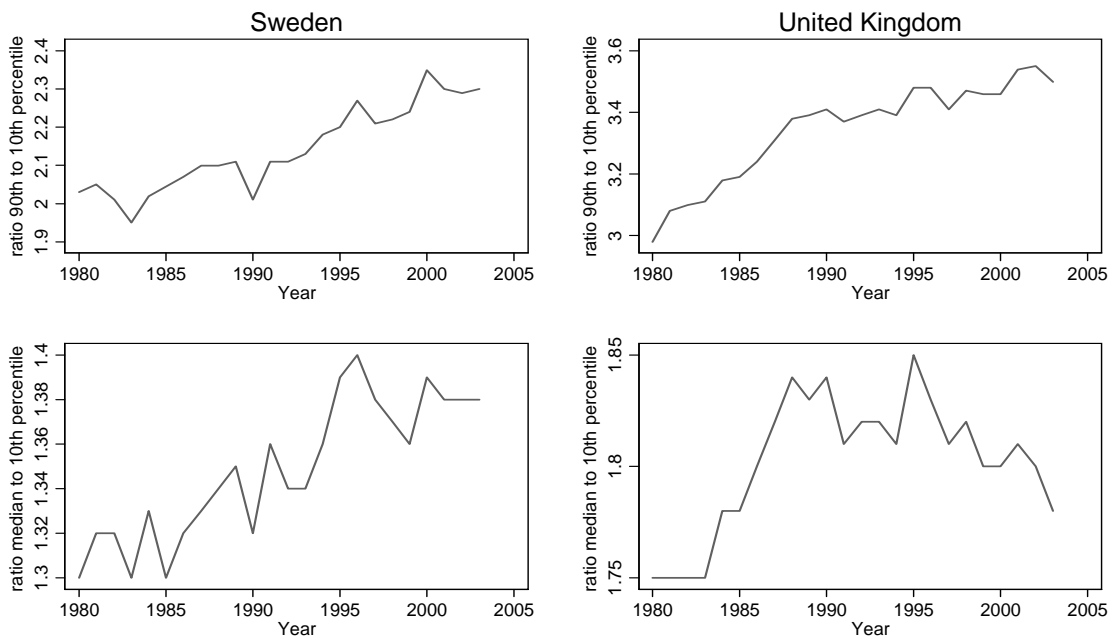

Figure 9e. Wage inequality in Sweden and in the UK

Note: Top panel: ratios of 90th percentile to the 10th percentile of the wage distribution; bottom panel: ratio of median wage to the 10th percentile of the wage distribution. The vertical scale is different in all graphs. 



\section{Fiscal costs of financial sector support: Measures and Implications*}

Daehaeng Kim and Manmohan S. Kumar **

\section{Summary}

In response to the global economic and financial crisis, many countries provided significant support to their financial sectors to prevent systemic failure and stabilize market conditions. While the magnitude and nature of support measures varied markedly across countries, with a preponderance of support in advanced countries, interventions were unusually bold and speedy. Actual utilization has been generally low, reflecting the precautionary nature of initial pledges, the need to err on the side of caution, and effectiveness of the initial responses. Despite relatively low recovery to date, the net budgetary cost of the financial sector support measures is likely to be below historical norms. This reflects the fact that support from the budget, such as capital injections and asset purchases, has been limited compared to past episodes, augmented by extensive use of containment measures as well as large fiscal

Keywords: Financial crisis, financial sector support measures, fiscal costs JEL Classification Numbers: G18, H63, H81

\footnotetext{
${ }^{*}$ The views expressed here are those of the authors and do not necessarily represent those of the IMF or IMF policy. We are grateful to Carlo Cottarelli, Steinar Holden, Mats Persson, and colleagues in the Monetary Capital Markets Department of the IMF for their comments and suggestions on earlier versions of the analysis contained in this paper. Estimates of financial sector support are based on a survey of major economies and build on analyses in IMF (2009b) and IMF (2010a) and are as of May 2010.

${ }^{* *}$ Fiscal Affairs Department, International Monetary Fund.
} 
and monetary expansions. However, the broader measures of the costs of the crisis, in terms of the fiscal impact of induced recessions and real economy costs, are estimated to be very high, thereby leading to a projected public debt surge in advanced G-20 economies.

In response to the global economic and financial crisis, many G-20 countries provided significant support to their financial sectors to prevent systemic failure or extreme disruptions, stabilize conditions, and boost market confidence. While the magnitude and nature of support measures varied markedly across countries, with a preponderance of support in advanced countries, interventions were generally striking and unusually quick. Support measures encompassed recapitalizations, asset purchases and swaps, asset/liability guarantees, deposit insurance, and liquidity support. These interventions had substantial fiscal implications in terms of upfront outlays and for the medium term.

An assessment of pledged and actual outlays was initially undertaken by IMF staff (see IMF, 2009b); it was then updated and revised following a survey questionnaire of the G20 countries. The survey was sent to all G20 members in early December 2009. Countries were requested to review and update staff estimates of direct support to financial sectors, regarding recapitalization and asset purchases; liquidity support comprising asset swaps and Treasury purchases; and contingent support consisting of deposit insurance and guarantees. For each type of support, data were compiled for financial support that was initially announced or pledged, the amount of support by instrument actually utilized; and the amounts recovered to-date.

Our analysis and discussion rely on the above estimates. Section 1 provides an assessment of the financial sector support measures. Section 2 considers short-term effectiveness of these measures, estimates of gross costs, recovery, and net cost to date. This is followed in Section 3 by a discussion of the medium-term fiscal implications. The last section provides concluding remarks. 


\section{Financial sector support measures: Pledged amounts and actual take-up}

\subsection{Pledged support and initial financing requirement}

The announced or pledged support for capital injections and asset purchases has varied significantly across countries.

- Capital injections. As of end-December, 2009, eight countries had injected or announced an intent to inject public funds directly into financial institutions, particularly those which were systematically important. The pledged outlay for advanced G-20 economies was estimated at USD 1,220 billion, equivalent to 3.8 percent of GDP. The corresponding amount in the emerging G-20 economies was USD 90 billion, or 0.7 percent of GDP. Within both groups, there was significant variation in the capital injections, with the bulk accounted for by Germany, Japan, Russia, the United Kingdom, and the United States (Table 1).

- Asset Purchases. Governments and some central banks also purchased illiquid financial assets to improve the liquidity position of financial institutions as well as mortgage markets. Again, the amounts involved ranged widely, with Canada and Japan accounting for over 9 and 4 percent of GDP, respectively. The amount pledged by the advanced G20 economies was USD 756 billion, or 2.4 percent of GDP (Table 1).

As the crisis was beginning to threaten a complete collapse of financial systems, the amounts announced or pledged for guarantees, liquidity support and expansion of deposit insurance in advanced economies were even larger.

- Asset/Liability guarantees. Substantial funds were pledged for guaranteeing banks' liabilities and assets, amounting to nearly 11 percent of GDP (Table 1). Guarantees for some form of wholesale debt and interbank liabilities were most widely (and effectively) used as a containment measure, almost entirely in the advanced G-20 economies. Guarantees for bank assets have been provided in the United Kingdom and the United States. 
- Direct lending and liquidity facilities. Central bank support was provided primarily by scaling up liquidity support and additional nonstandard measures, including extending credit lines to financial institutions, expanding the list of assets eligible as collateral, and lengthening the maturities of long-term refinancing operations. Reflecting these measures, central bank balance sheets in several advanced G-20 countries and, in particular, claims on financial institutions, have expanded sharply (Table 2). Central bank support through asset swaps and mortgage backed securities (MBS)/Treasuries purchases has been announced in only a few economies, and the amount pledged was particularly large in the United Kingdom and the United States (Table 1).

- Deposit insurance. Several governments expanded the coverage of deposit insurance to different types of deposits (Germany), raised the limit for the amounts covered (Indonesia, Russia, Saudi Arabia, the United Kingdom, and the United States), or adopted for the first time a deposit insurance system (Australia) to maintain depositor confidence. While the European Union (EU) authorized an increase in coverage, most of the G-20 EU countries already had protection levels at or above the enhanced level (France, Italy, and Germany).

Even though amounts pledged for these support measures were large, the immediate impact on public debt has been quite limited. Announced support has been largely extended via crisis containment measures, such as guarantees and liquidity support. Guarantees, as well as central bank support, do not require upfront government financing in most cases, although they lead to a significant build up of contingent liabilities. Therefore, governments' direct liabilities have been increased far less than the total size of support measures. Government financing requirements largely reflected injection of capital and purchase of assets. ${ }^{1}$ Upfront commitment of such support is estimated at 5.0 percent and 0.2 percent of GDP for the advanced and emerging G-20 economies, respectively (Table 1).

\footnotetext{
${ }^{1}$ Government upfront financing needs also depend on the financing arrangements among institutions involved in the support measure. For example, some governments have provided guarantees for the borrowing undertaken by a special vehicle company that purchases illiquid assets. This type of support is classified as asset purchases, instead of guarantees, to better reflect the intention of the support, and it has no immediate impact on the government's direct liabilities.
} 


\subsection{Composition and time pattern of support measures}

Support measures have varied significantly across countries and thus reflect differing economic and financial circumstances ${ }^{2}$. In countries most exposed to the financial crisis (e.g., United States and United Kingdom), almost all types of support measures were utilized. In countries exposed to the secondround effects of the crisis, including sudden capital outflows and weak external demand (e.g., Asian and East European countries), interventions focused more on domestic and foreign exchange liquidity. Some countries used state-owned financial institutions to address credit bottlenecks (e.g., France, Japan, and Korea), including directed lending; others used sovereign wealth fund assets rather than issuing debt. Countries with weak fiscal positions and limited borrowing capacity adopted measures with low initial cost, such as guarantees, or involved off-budget public entities to avoid affecting the measured fiscal balance.

The cumulative set of financial sector support measures provided in major advanced economies since June 2007 reveals several notable patterns (IMF, 2009c). Before the Lehman Brothers' collapse on September 14, 2008, financial sector support measures were predominantly provided by central banks, with a relatively narrow focus on preventing the downward spiral of counter-party confidence and unfreezing interbank markets. Immediately following the Lehman collapse, more frequent and diverse types of public interventions were announced by both central banks and governments in an environment of severe market uncertainties and concerns (Figure 1). From September to December 2008, expectations of a deep economic downturn, associated with the financial crisis, began to take hold and most governments announced fiscal stimulus measures to prevent a worsening of the feedback loop between the real and financial sectors. From January 2009 onwards, diverse but lower-frequency interventions continued, while over the past few months, a winding down of the process of financial sector support has begun.

\footnotetext{
${ }^{2}$ For details of financial sector support measures in a broader set of countries, see IMF (2009a).
} 


\subsection{Utilized support}

The utilized amount of financial sector support is estimated to have been much less than the pledged amounts. For the advanced G-20 economies, the average amount utilized for capital injection was USD 639 billion, that is 2 percent of GDP or just over half the pledged amount (Table 3). France, Germany, the United Kingdom and the United States accounted for over 90 percent of this figure. In the advanced G-20 economies, the utilized amount for asset purchases was around 1.4 percent of GDP, less than two-thirds of the pledged amount. Similarly, the uptake of guarantees has been significantly less than pledged. The amounts utilized in the emerging G-20 markets have been proportionately even lower.

There are several reasons for the generally low utilized amounts. To some extent, the low utilization rates might reflect the precautionary nature of initial pledges, which may have been large in part given the uncertainties prevailing at the time, and the need to err on the side of caution so as to increase market confidence. In addition, the lower rates seemed to reflect more efficient use of government resources, e.g., using capital injections rather than asset purchases. They also reflected increasing stability of market conditions and improving bank liquidity (uptakes slowed down markedly after initial recapitalizations). In some cases, lags in implementation of programs for recapitalization and asset purchases, as well as overlap in the coverage of some measures, might have also played some role. ${ }^{3}$

\section{Financial sector support: Effectiveness, recovery, and net cost to-date}

\subsection{Effectiveness of support measures}

Public interventions announced and implemented during the crisis were generally effective in supporting markets and re-establishing financial stability. Although it may be somewhat premature for a comprehensive assessment of the effectiveness of the financial sector support measures, the event study reported in IMF (2009c) found strong indications that in the early

\footnotetext{
${ }^{3}$ The proliferation of liquidity support measures in particular may have generated significant redundancies — overlapping facilities or measures superseded by other measures.
} 
phase of the crisis, when market uncertainty and counter-party risks were high, announcements of liquidity support measures were the most promising, while announcements of recapitalization and, to a lesser extent, asset purchases were more effective in alleviating credit risks in the later phase of the crisis. In general, the support measures were certainly seen to be effective in the short run. Specifically, announcements of liquidity support measures at the initial phase of the crisis reduced the LIBOR-OIS spread. ${ }^{4}$ However, the effect of the liquidity measures was not found to be statistically significant as the crisis worsened and markets began to anticipate the provision of more liquidity or different types of support. The finding of diminishing effectiveness of liquidity measures in the later stages of the crisis is consistent with the notion that the crisis evolved from one of liquidity to one of solvency.

Most of the capitalization measures were provided during the latter stage of the crisis. The announcements of capital injections had a significant impact on the average composite credit default swap (CDS) spread, indicating that they were effective in reducing credit risk. Further, the effectiveness of capital injections was found to be larger when they were combined with other measures (e.g., asset guarantees in the United Kingdom) or when they were repeated (e.g., a second round of capital injection in the euro area). In contrast, the effectiveness of announcements of asset purchases and liability guarantees was seen to be mixed: these were found to be more effective in reducing a country's average bank CDS spread in the euro area and the United Kingdom than in Japan and the United States.

\subsection{Recovery to-date and new measures adopted or proposed}

Many of the support arrangements were structured so that the financial sector would pay, at least in part, for the cost of support over time. Recoveries related to capitalization efforts will reflect repurchases, dividends, and the sale of warrants. For asset protection schemes, banks paid to participate and were charged fees for signing up and/or early exit. Fees were also received for the provision of guarantees and for deposit insurance funds, and monies were sometimes recouped from special levies assessed on the banking sector.

\footnotetext{
${ }^{4}$ LIBOR is the London InterBank Offered Rate; OIS is the Overnight Index Swap rate. The LIBOR-OIS spread is often interpreted as the best way to measure the effectiveness of the coordinated action by central banks to improve the willingness among banks to lend.
} 
As economic conditions and markets have stabilized, some recovery of outlays has begun, but to date it has been relatively low. ${ }^{5}$

Recovery of outlays by end-2009 amounted to USD 237 billion or 0.8 percent of GDP for the advanced G-20 economies (Table 4). When this is taken into account, the net cost of direct support - recapitalizations and asset purchases - is estimated at 2.8 percent of GDP for advanced G-20 economies, thereby implying a recovery rate to date of 21 percent. While this is significantly lower than the average recovery rate in past crises in advanced countries (55 percent), historically most of the recovery has occurred over a period of five to seven years post crisis (Laeven and Valencia, 2010). Recovery to date has occurred mainly through the repurchase of shares and warrants, and via dividends, with the bulk accounted for by France, the United Kingdom, and the United States.

To further reduce the cost of direct support and increase recovery, some countries have adopted or proposed special levies on the financial sector. ${ }^{6}$ Examples include a financial crisis responsibility fee proposed in the United States, and temporary taxes on bonuses adopted in France and the United Kingdom. In addition, some countries intend to set up mechanisms to prefund the cost of possible future crises. These include a bank levy proposed in Germany, a dissolution fund in the United States, and a financial stability fund introduced in Sweden (all linked to financial-sector resolution schemes; see Box 1).

\footnotetext{
${ }^{5}$ Recovery does not include unrealized gains on assets acquired by the public sector as part of the financial sector support package. Recovery occurs only when these gains are realized as the assets are divested. Estimates are as of end-May 2010.

${ }^{6}$ In this context, the IMF was asked by the G-20 heads of state to prepare a report for their June 2010 meeting. The report focuses on the range of options already adopted or under consideration regarding how the financial sector could make a fair and substantial contribution toward paying for any burden sharing associated with governmental intervention to repair the banking system. A preliminary version of this report was forwarded to the G-20 Minister of Finance in April 2010. See http://blog-imfdirect.imf.org/2010/04/25/fair-and-substantial\%E2\%80\%94taxing-the-financialsector/
} 


\section{Medium-term fiscal implications of financial sector support}

The medium-term net fiscal cost of financial sector support will hinge on the durability of economic recovery and the further restoration of financial sector stability. In addition, proper management of financial assets and liabilities built up during the crisis will be essential to minimize the net cost of financial sector support measures. Specifically, the net cost of these measures will depend on the utilization rate of the announced measures, the size of subsidy component of the measures, the potential materialization of contingent liabilities, and the extent to which the assets acquired by governments or central banks can be disinvested without losses. Although significant uncertainties surround each of these channels, not least affected by recent developments in Europe and their broader implications, as well as unique features of the crisis, past experience can provide some guidance for asset recovery over the medium term.

\subsection{Recovery of assets and net cost of direct support measures}

The amounts recovered from the sale of assets acquired through interventions will likely vary significantly across countries, depending on the type of intervention, the approach adopted in managing and selling the assets, and various macroeconomic factors (IMF, 2009a). Econometric analysis based on 39 financial crisis episodes during 1980-2003 suggests that recovery rates are positively correlated with per capita income: advanced countries had higher recovery rates - an average of 55 percent compared with 13 percent for emerging market economies in past banking crisis. Recovery rates are also higher, the stronger the fiscal balance at the start of the crisis, possibly an indicator of sounder fiscal and public financial management frameworks (IMF, 2009b). Recovery rates tended to be lower when a financial crisis was coupled with an exchange rate crisis. This could reflect the fact that initial outlays arose from the acquisition of liabilities that were inflated by sizable and permanent depreciations, as well as high interest rates. Other 
variables associated with lower recovery rates include transition country dummies and the gross fiscal cost of the crisis. ${ }^{7}$

These estimates suggest that although uncertainties abound, the direct net budgetary cost could be well below historical norms. ${ }^{8}$ This reflects in part extensive use of containment measures during the current crisis: total expenditures in recapitalization and asset purchases to address the crisis have been below historical averages, while guarantee and liquidity support measures, which tend to be less costly to the government, have been used more extensively. Bank recapitalization expenditure for countries undergoing a systemic crisis in the past has averaged 8 percent of GDP (Laeven and Valencia, 2008). According to their definition, only three G-20 countries experienced a systemic crisis in 2007-09 (the United States, the United Kingdom and Germany) and their direct fiscal outlays have been lower, averaging 5.4 percent of GDP. In addition, fiscal stimulus through automatic stabilizers, discretionary measures, or both seems to have raised prospects for recovery and helped stabilize the financial sector by limiting negative feedback loops between the financial sector and the real economy. In contrast, historically, many crisis countries faced limited fiscal space and had to tighten fiscal policy. Despite markedly low recovery rates in past crises, the net cost of financial sector support for emerging market economies would be significantly smaller than for the advanced economies, given the much smaller impact of crisis and limited government support in emerging market economies.

\subsection{Net cost of liquidity support and guarantees}

Potential cost of central banks' liquidity support measures is likely to be even more limited than those of direct government intervention. Given the unprecedented magnitude of central bank support programs during the current crisis, there is little historical evidence to assess likely recovery rates.

\footnotetext{
${ }^{7}$ Recovery of the initial outlays was lower in transition economies. Though statistically insignificant, recovery rates were lower, the higher the gross fiscal cost of the crisis.

${ }^{8}$ Though volatile, a mark-to-market valuation of the assets acquired by the government during the crisis could provide some indication of the extent of future recovery by divesting the assets. For example, in the United Kingdom, £69.7 billion worth of common stocks were purchased for recapitalizing banks, $£ 2.56$ billion of which have been sold. The market value of the common stocks still held by the government was around $£ 57.6$ billion at end-2009, and improved further to $£ 70$ billion as of end-April, 2010, implying that if divested now, this particular support measure may be able to generate net gains to the government.
} 
However, in most countries, central banks have focused on providing liquidity support with relatively short maturities, higher-quality collateral, and sometimes guarantees from the Treasury or Deposit Insurance Agencies, whereas governments have generally provided solvency support - operations with a much greater assumption of risk by the government and some purchases of assets at prices much above their fair values. Therefore, the recovery of central bank outlays would be significantly higher than that of direct government support. ${ }^{9}$

Net cost of guarantees in comparison to the size of protection is generally much smaller than that of other measures due to their precautionary nature. The expected cost of the (explicit) guarantees provided so far is low, but the margin of uncertainty is large. Some indicative estimates can be obtained using standard financial derivative pricing models - in particular, by estimating the expected default frequency implied by credit default swap (EICDS) spreads and applying them to the guaranteed amounts. EICDS can be regarded as indicative of the "insurance" premium for providing the guarantees. The approach - which takes into account market volatility and hence the probability of default of individual institutions - provides an approximate measure of the cost to government of providing this "insurance." Based on November 2008 market data, outlays from contingent liabilities could be on the order of 1/1/2-4 percent of GDP (cumulative) for 2009-13 for the advanced G-20 countries, with a point estimate of 2 percent of GDP (IMF, 2009b). However, the current expected cost of guarantee measures would be even lower than that estimated in late 2008, thereby reflecting expiration of some guarantee programs without any losses, as well as significant improvements in market conditions since late 2008.

\footnotetext{
${ }^{9}$ For instance, the United States' Congressional Budget Office (2010) estimated that as of the date of inception of the main programs, "the fair value subsidies conferred by the Federal Reserve System's actions to stabilize the financial markets totaled about USD 21 billion.” This estimate reflects ex ante opportunity cost of the support measures provided by the Federal Reserve System, and not expected losses of the measures. In total, "the fair-value subsidies that CBO has estimated are modest when compared, for instance, with CBO's estimate of the USD 189 billion subsidy provided by the TARP (Troubled Asset Relief Program) at its inception,” while the amount of support from the Federal Reserve System is substantially larger (at least over 10 times) than the amount of support from the TARP.
} 


\subsection{Cost of the crisis and medium-term fiscal outlook}

Nonetheless, it is important to emphasize that the above cost estimates refer only to a small subset of the overall cost of the crisis. The broader measures of costs, including the fiscal impact of induced recessions, are estimated to be significantly higher than direct costs of financial sector support. Importantly, total debt burden has risen dramatically for almost all advanced G-20 countries and uncertainties in the markets continue to be partly related to the high risk exposures of sovereign balance sheets. Laeven and Valencia (2010) estimate the average increase in public debt to be about 24 percent of GDP and the output losses to be about 27 percent of potential GDP for the countries that experienced a systemic banking crisis during the period in 2007-2009. These estimates are not significantly different from past crisis episodes ${ }^{10}$

The direct cost of financial sector support is expected to account for less than one tenth of the projected increase in public debt in advanced G-20 countries during 2008-15 (Figure 2). Rather, the projected debt surge by almost 39 percent of GDP in advanced G-20 economies will be driven mostly by the output collapse and the related government revenue loss, i.e., about two thirds of the overall debt increase. ${ }^{11}$ Fiscal stimulus - assuming it is withdrawn as planned - would account for about one-tenth of the total debt increase. A fairly sizable component arises from lending operations in some countries (Canada, South Korea, and the United States) involving student loans, loans for consumer purchases of vehicles, and support to small and medium-sized enterprises - arguably in response to the crisis. In emerging G-20 economies, debt dynamics are projected to be more favorable, thus reflecting the much smaller impact of crises and stronger growth. ${ }^{12}$

The projected large increase in public debt in advanced economies could weigh on economic growth for years to come, further exacerbating the debt position. Kumar and Woo (2010) suggest that, based on current debt projections, if public debt is not lowered to pre-crisis levels, poten-

\footnotetext{
${ }^{10}$ Laeven and Valencia (2010) also note that this time around, policies to address banking solvency were implemented much sooner than in the past, which may have contributed to keeping direct outlays relatively low.

${ }^{11}$ In particular, the fall in GDP in 2008-09 led to an unfavorable interest-growth differential, in spite of falling interest rates. The revenue weakness reflected the opening of the output gap, but also revenue losses from lower asset prices and financial sector profits.

${ }^{12}$ Public debt in 2015 is projected to be almost 5 percentage points of GDP lower than before the crisis for the emerging G-20 economies.
} 
tial growth in advanced economies could be lower by 0.5 percentage points annually, a very sizable effect when cumulated over several years. The adverse effects of high debt on growth appear to occur through a variety of channels, including higher real interest rates and a slowdown in labor productivity growth, mainly due to slower growth of the capital stock per worker; there is also a mild direct relationship between higher debt and total factor productivity growth.

In addition to the higher projected financing needs over the medium term, the supply of government securities will also be affected by the eventual unwinding of large positions taken by some central banks (Table 5). The largest purchases were made by the Bank of England which, since mid-2008, has acquired gilts in excess of 14 percent of GDP, more than a fifth of the outstanding gross debt of the general government of the United Kingdom. ${ }^{13}$ Purchases of government securities were part of an array of extraordinary emergency operations motivated by monetary policy objectives, namely the continued expansion of liquidity when the policy interest rate reached levels close to its zero bound and many financial markets had seized up. ${ }^{14}$ As liquidity conditions and interest rates gradually return to more normal levels, central banks can be expected to unwind these operations and further increase the supply of government securities (or central bank instruments) in the market, which may improve some capital flows over the medium term.

\footnotetext{
${ }^{13}$ While average government debt maturities have shortened somewhat since mid-2009, reflecting actual or anticipated difficulties in placing longer-term bonds or cost consideration in some cases, the United Kingdom stands out with an exceptionally long maturity (12.8 years). This reflects in part a deliberate strategy to lengthen maturities and is facilitated by the size of its financial system (including large pension and insurance industries). However, some economies with large debt ratios, such as Japan, have relatively short average maturities (5.2 years). For more details, see IMF (2010a).

${ }^{14}$ On May 10, 2010, the European Central Bank (ECB) announced that it will conduct interventions in the euro area public and private debt securities markets, and eurosystem central banks started purchasing sovereign debt (for example, €16.5 billion through transaction settlement during May 11-12).
} 


\section{Conclusion}

Faced with an unprecedented risk to the stability and solvency of their financial sectors, the advanced G-20 countries in particular acted with bold measures. These are widely considered to have been successful in averting an economic catastrophe and in stabilizing market conditions. The above analysis suggests that the direct budgetary costs of financial sector support are likely to be smaller than that of support provided in past crises. However, fiscal positions in the advanced economies have deteriorated considerably due to the crisis, which will have important implications for fiscal policies in the medium term. This is particularly so, given the underlying increases in budgetary pressures stemming from demographic changes and increases in pension and health care spending. As a consequence, clear exit strategies and adjustment plans are called for to maintain market confidence and place public finances on a sustainable path. 


\section{Box 1. Key Tax or Contribution-Related Measures}

1. Actual and proposed steps to recover the outlays related to the crisis and reduce excessive risk taking include:

- The United States Financial Crisis Responsibility Fee (FCRF). In January, 2010, the United States government announced that it would seek to impose a 0.15 percent tax on the uninsured liabilities - defined as total assets net of tier I capital and insured deposit - of large financial institutions. The government estimates that the FCRF will raise additional revenue of USD 90 billion during 2011-20, and it intends to impose the FCRF until the Troubled Asset Relief Program is fully paid off. United States corporations will be taxed on their worldwide consolidated assets, while foreign entities in the United States market will be taxed based only on their U.S. assets.

- The United Kingdom Bank Payroll Tax (BPT). The United Kingdom government introduced a tax on bonuses paid to bank employees, effective from December 9, 2009 to April 5, 2010, to address "remuneration practices that contributed to excessive risk-taking by the United Kingdom banking industry" and "encourage banks to consider their capital position and to make appropriate risk-adjustments when settling the level of bonus payments.” The BPT applies to all bonus payments in excess of £25,000 made by banks and building societies to their employees. The BPT expired on April 5, 2010. The U.K. Treasury originally forecast that the BPT will raise GBP 550 million in revenue, but more recent information indicates that the tax could bring in an amount on the order of GBP 2.5 billion.

- The Bonus Tax in France. The French government has implemented a temporary tax on bonuses granted in 2009 by banks and other financial institutions (excluding insurance and portfolio management companies). Employers in France will be liable to the tax with respect to relevant employees whose activities may significantly affect the risk exposure of their companies and those who have control over the enterprises. The tax is levied at 50 percent on bonuses in excess of EUR 27,500 , and is deductible against corporate income tax. The tax was projected to yield EUR 362.5 million. 
2. Actual and proposed steps to prefund the cost of possible future crises include:

- The United States Systemic Dissolution Fund (SDF). The United States House Financial Services Committee approved a measure that would set up the SDF within the U.S. Treasury (managed by the FDIC) to finance the orderly dissolution of a given financial company as needed. Financial firms with more than USD 50 billion in assets and hedge funds with more than USD 10 billion in assets will be covered by the SDF. Covered institutions will be subject to a periodic assessment, which they will pay on a continuous basis. The fee will be accumulated in the SDF up to a certain level (the target has yet to be determined within the legislative maximum of USD 150 billion), and once the target is reached, the fee will be paid to general revenues.

- The Bank Levy in Germany. In March 2010, the German government announced plans to introduce a systemic risk-adjusted bank levy to mitigate the negative externalities associated with systemic risks. Systemic risk will be determined, among other considerations, on the basis of the size of banks' liabilities excluding capital and deposits and their interconnectedness with other financial market participants. The levy is to be paid into a stability fund that will be used to finance a special resolution regime for systemically relevant banks. The fund and the special resolution regime will be entrusted to the Federal Agency for Financial Market Stabilization. The size of the fund is yet to be determined.

- The Swedish Financial Stability Fund (SFSF). The SFSF was introduced as the financing vehicle of four instruments available to the Swedish government to protect financial stability: bank guarantees, capital injections, emergency support, and deposit insurance. The SFSF covers deposit-taking institutions incorporated in Sweden, with a target size of 2.5 percent of GDP in 15 years. The SFSF is supported by an unlimited government back stop, and it is expected to merge with the deposit insurance fund in 2011. Covered institutions pay a flat-rate fee levied on a portion of their liabilities: total assets net of equity capital, junior debt securities included in the capital base, debt transactions between companies paying stability fees, and an average of the guaranteed liabilities. The fee rate is 0.036 percent, payable annually, but transition rules allowed banks to pay only 50 percent of the prescribed rate for 20092010. The fee will be risk-based from 2011, but no details are available regarding how risk weighting will be implemented and how it will be merged with the deposit insurance fee. 
Fiscal costs of financial sector support: Measures and implications for fiscal policv 165

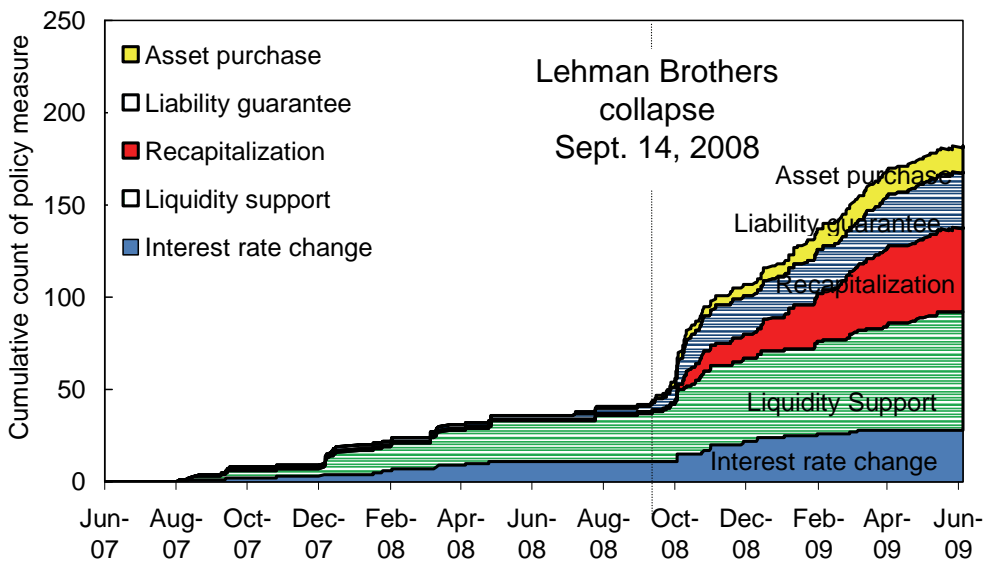

Figure 1. Time pattern of support measures in sample countries (June 1, 2007 - June 30, 2009)

Source: IMF Global Financial Stability Report, Oct 2009

Note: Sample countries include the Euro area, Japan, Sweden, Switzerland, United Kingdom, and United States. This figure adds up the total number of policy measures introduced over time; it disregards the scale of each intervention, in both relative and absolute terms.

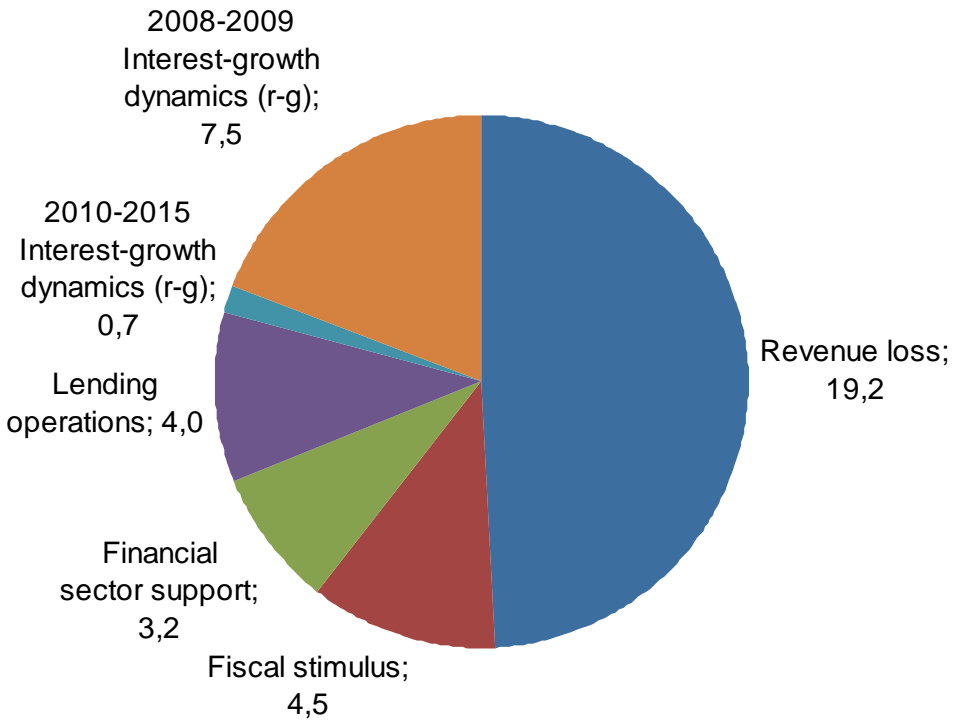

Figure 2. Advanced G-20 economies:Contributions to increase in public debt, 2008-15 (in percentage points of GDP) (Total increase: 39.1 percentage points of GDP; 2009 $P P P$ weighted GDP.)

Source: IMF (2010a); IMF staff estimates based on the April 2010 World Economic Outlook (2010b). 
Table 1. Amounts pledged for financial sector and upfront financing need in G-20 economies (In percent of 2009 GDP unless otherwise noted)*

\begin{tabular}{|c|c|c|c|c|c|}
\hline & $\begin{array}{c}\text { Capital } \\
\text { Injection }\end{array}$ & $\begin{array}{c}\text { Purchase of } \\
\text { Assets }\end{array}$ & $\begin{array}{c}\text { Guarantees } \\
\text { a) }\end{array}$ & $\begin{array}{c}\text { Asset Swap } \\
\text { and MBSI } \\
\text { Treasuries } \\
\text { Purchases } \\
\text { by Central } \\
\text { Bank }\end{array}$ & $\begin{array}{c}\text { Upfront } \\
\text { Government } \\
\text { Financing b) }\end{array}$ \\
\hline \multicolumn{6}{|l|}{ Advanced Economies } \\
\hline Australia & 0.0 & 0.0 & 13.2 & 0.0 & 0.0 \\
\hline Canada & 0.0 & 9.1 & 0.0 & 0.0 & 9.1 \\
\hline France & 1.3 & 0.2 & 16.9 & 0.0 & 1.1 \\
\hline Germany & 3.4 & 0.0 & 17.2 & 0.0 & 3.4 \\
\hline Italy & 1.3 & 0.0 & 0.0 & 2.7 & 2.7 \\
\hline Japan & 2.5 & 4.1 & 7.2 & 0.0 & 0.4 \\
\hline Korea & 1.2 & 1.5 & 11.6 & 0.0 & 0.8 \\
\hline United Kingdom & 8.2 & 3.7 & 40.0 & 28.2 & 8.7 \\
\hline United States & 5.1 & 2.3 & 7.5 & 12.1 & 7.4 \\
\hline \multicolumn{6}{|l|}{ Emerging Economies } \\
\hline Argentina & 0.0 & 0.0 & 0.0 & 0.0 & 0.0 \\
\hline Brazil & 0.0 & 0.8 & 0.5 & 0.0 & 0.0 \\
\hline China & 0.0 & 0.0 & 0.0 & 0.0 & 0.0 \\
\hline India & 0.0 & 0.0 & 0.0 & 0.0 & 0.0 \\
\hline Indonesia & 0.0 & 0.0 & 0.0 & 0.0 & 0.0 \\
\hline Mexico & 0.0 & 0.0 & 0.0 & 0.0 & 0.0 \\
\hline Russia & 7.1 & 0.5 & 0.0 & 0.0 & 1.9 \\
\hline Saudi Arabia & 0.0 & 0.0 & 0.0 & 0.0 & 0.0 \\
\hline South Africa & 0.0 & 0.0 & 0.0 & 0.0 & 0.0 \\
\hline Turkey & 0.0 & 0.0 & 0.0 & 0.0 & 0.0 \\
\hline G-20 Average c)l & 2.6 & 1.4 & 6.4 & 4.6 & 3.1 \\
\hline Advanced Economies & 3.8 & 2.4 & 10.9 & 7.7 & 5.0 \\
\hline In billions of USD & 1,220 & 756 & 3,530 & 2,400 & 1,610 \\
\hline Emerging Economies & 0.7 & 0.1 & 0.04 & 0.0 & 0.2 \\
\hline In billions of USD & 90 & 18 & 7 & 0 & 24 \\
\hline
\end{tabular}

Source: International Monetary Fund Staff estimates based on responses to G-20 Survey.

Notes: *Estimates indicate announced or pledged amounts, and not actual uptake. Survey questionnaires were sent to all G-20 members in early December 2009. Countries were requested to review and update staff estimates of direct support to financial sectors, consisting of recapitalization and asset purchases; liquidity support comprising asset swaps and treasury purchases; and contingent support consisting of deposit insurance and guarantees. For each type of support, data were compiled for financial support that was initially announced or pledged; amount of support actually utilized; and amounts recovered to-date. Period covered was June 2007 to December 2009.

a) Excludes deposit insurance provided by deposit insurance agencies; ${ }^{\text {b) }}$ Includes pledged gross support measures that require upfront government outlays, and excludes recovery from the sale of acquired assets; ${ }^{c}$ PPP GDP weighted averages. 
Table 2. Changes in central bank balance sheet (In percent of 2009 GDP)

\begin{tabular}{|c|c|c|c|}
\hline & Total Assets $^{a)}$ & Monetary Base $^{\text {b) }}$ & $\begin{array}{r}\text { Claims on financial } \\
\text { institutions }^{c}\end{array}$ \\
\hline \multicolumn{4}{|c|}{ Advanced North America } \\
\hline Canada & 1.3 & 0.6 & 1.6 \\
\hline United States & 9.6 & 8.0 & 2.8 \\
\hline \multicolumn{4}{|l|}{ Advanced Europe } \\
\hline United Kingdom & 11.3 & 9.8 & -2.9 \\
\hline Euro Area & 7.2 & 2.6 & 8.6 \\
\hline \multicolumn{4}{|c|}{ Advanced Asia and Pacific } \\
\hline Australia $^{\mathrm{d})}$ & -3.6 & 1.1 & 0.0 \\
\hline Japan & 4.7 & 3.3 & 4.2 \\
\hline Korea & 5.0 & 1.6 & 0.4 \\
\hline \multicolumn{4}{|c|}{ Emerging Economies } \\
\hline Argentina & 6.6 & 5.1 & -0.3 \\
\hline Brazil & 15.7 & 0.7 & 0.2 \\
\hline China & 23.7 & 17.9 & -2.9 \\
\hline India & 9.8 & 4.9 & 0.0 \\
\hline Indonesia & 1.3 & 3.0 & 0.0 \\
\hline Russia & 10.8 & 4.7 & 4.8 \\
\hline Saudi Arabia ${ }^{\mathrm{e}}$ & 43.6 & 4.0 & $\ldots$ \\
\hline Turkey & 0.1 & 3.0 & 3.6 \\
\hline
\end{tabular}

Sources: International Financial Statistics, World Economic Outlook, monetary authorities

Notes: ${ }^{\text {a) }}$ Changes in central bank total assets between June 2007 and Dec 2009. ${ }^{\text {b) }}$ Changes in monetary base or reserve money between 2007 (annual average) and Dec 2009. ${ }^{c)}$ Changes in central bank claims on financial institutions between June 2007 and Dec 2009. ${ }^{d)}$ Excluding foreign exchange and gold operations, the balance sheet increased by 0.1 percent of GDP. ${ }^{\text {e) }}$ Reflects large build-up of foreign assets until the first half of 2008 due to strong oil prices. 
Table 3. Financial sector support utilized relative to announcement (In percent of 2009 GDP, unless otherwise noted)

\begin{tabular}{|c|c|c|c|c|}
\hline & \multicolumn{2}{|l|}{ Capital Injection } & \multicolumn{2}{|c|}{ Purchase of Assets } \\
\hline & Amount used & $\begin{array}{l}\text { In percent of } \\
\text { annoucement }\end{array}$ & Amount used & $\begin{array}{l}\text { In percent of } \\
\text { annoucement }\end{array}$ \\
\hline \multicolumn{5}{|l|}{ Advanced Economies } \\
\hline Australia & 0.0 & $\ldots$ & 0.0 & $\ldots$ \\
\hline Canada & 0.0 & $\ldots$ & 4.4 & 48.4 \\
\hline France & 1.1 & 83.2 & 0.0 & 0.0 \\
\hline Germany & 1.2 & 35.0 & 3.7 & $\ldots$ \\
\hline Italy & 0.3 & 20.3 & 0.0 & $\ldots$ \\
\hline Japan & 0.1 & 2.4 & 0.1 & 1.4 \\
\hline Korea & 0.4 & 32.5 & 0.1 & 3.8 \\
\hline United Kingdom & 6.4 & 78.5 & 0.1 & 4.0 \\
\hline United States & 2.9 & 57.0 & 1.9 & 84.0 \\
\hline \multicolumn{5}{|l|}{ Emerging Economies } \\
\hline Argentina & 0.0 & $\ldots$ & 0.0 & $\ldots$ \\
\hline Brazil & 0.0 & $\ldots$ & 0.3 & 43.5 \\
\hline China & 0.0 & $\ldots$ & 0.0 & $\ldots$ \\
\hline India & 0.0 & $\ldots$ & 0.0 & $\ldots$ \\
\hline Indonesia & 0.0 & $\ldots$ & 0.0 & $\ldots$ \\
\hline Mexico & 0.0 & $\ldots$ & 0.0 & $\ldots$ \\
\hline Russia & 3.1 & 43.0 & 0.0 & 0.0 \\
\hline Saudi Arabia & 0.0 & $\ldots$ & 0.0 & $\ldots$ \\
\hline South Africa & 0.0 & $\ldots$ & 0.0 & $\ldots$ \\
\hline Turkey & 0.0 & $\ldots$ & 0.0 & $\ldots$ \\
\hline G-20 Average & 1.3 & 51.7 & 0.9 & 60.2 \\
\hline Advanced Economies & 2.0 & 52.3 & 1.4 & 61.0 \\
\hline In billions of USD & 639 & $\ldots$ & 461 & $\ldots$ \\
\hline Emerging Economies & 0.3 & 43.0 & 0.03 & 27.5 \\
\hline In billions of USD & 38 & $\ldots$ & 5 & $\ldots$ \\
\hline
\end{tabular}

Source: International Monetary Fund Staff estimates based on responses to G-20 Survey.

Note: PPP GDP weighted averages. 
Table 4. Recovery of outlays and net cost of direct financial sector support through December 2009

(In percent of GDP, unless otherwise noted)

\begin{tabular}{lcccc}
\hline & \multicolumn{2}{c}{ Direct Support $^{\text {a) }}$} & Recovery $^{\text {b) }}$ & Net Direct Cost \\
\cline { 2 - 3 } & Pledged & Utilized & & \\
\cline { 2 - 3 } Advanced Economies & & & & \\
Australia & 0.0 & 0.0 & 0.1 & -0.1 \\
Canada & 9.1 & 4.4 & 0.0 & 4.4 \\
France & 1.5 & 1.1 & 0.8 & 0.3 \\
Germany & 3.4 & 4.9 & 0.0 & 4.8 \\
Italy & 1.3 & 0.3 & 0.0 & 0.3 \\
Japan & 6.6 & 0.1 & 0.0 & 0.1 \\
Korea & 2.7 & 0.5 & 0.4 & 0.1 \\
United Kingdom & 11.9 & 6.6 & 1.1 & 5.4 \\
United States & 7.4 & 4.9 & 1.3 & 3.6 \\
G-20 Average & 4.0 & $\mathbf{2 . 2}$ & 0.4 & 1.0 \\
Advanced Economies & 6.2 & 3.5 & 0.8 & 2.8 \\
In billions of USD & 1,976 & 1,100 & 237 & 862 \\
Emerging Economies & 0.8 & 0.3 & - & 0.3 \\
In billions of USD & 108 & 43 & - & 43 \\
\hline
\end{tabular}

Source: International Monetary Fund Staff estimates based on responses to G-20 Survey.

Notes: ${ }^{\text {a) }}$ Capital injections and asset purchases. ${ }^{\text {b) }}$ Recovery does not take into account unrealized gains.

Table 5. Central bank holdings of government securities (In percent of 2009 GDP, end of period) $)^{a)}$

\begin{tabular}{lrrrrrrr}
\hline & 2007Q4 & 2008Q2 & 2008Q4 & 2009Q2 & 2009Q4 & 2010Q1 & $\begin{array}{r}\text { Change } \\
\text { from } \\
\text { 2008Q2 }\end{array}$ \\
\hline Japan & 14.7 & 13.8 & 13.2 & 13.8 & 15.0 & 15.1 & 1.4 \\
United Kingdom & 0.0 & 0.1 & 0.3 & 7.3 & 13.8 & 14.5 & 14.4 \\
United States & 5.3 & 3.4 & 3.3 & 4.6 & 5.4 & 5.4 & 2.1 \\
\hline
\end{tabular}

Sources: National central banks' balance sheets and flow of funds.

Note: ${ }^{\text {a) }} 2010 \mathrm{Q} 1$ reports data as of February 2010 , or latest date available. 


\section{References}

Congressional Budget Office (2010), The budgetary impact and subsidy costs of the Federal Reserve's actions during the financial crisis, CBO Study (http://www.cbo.gov/doc.cfm?index=11524).

IMF (2009a), Crisis-Related Measures in the Financial System and Sovereign Balance Sheet Risks, IMF Policy Paper, International Monetary Fund, Washington, D.C. IMF (2009b), Fiscal implications of the global economic and financial crisis, IMF Occasional Paper 269, Washington, D.C.

IMF (2009c), Global Financial Stability Report - Navigating the Financial Challenges Ahead, World Economic and Financial Surveys, October, Washington, D.C.

IMF (2010a), IMF Fiscal Monitor - Navigating the Fiscal Challenges Ahead, World Economic and Financial Surveys, May, Washington, D.C.

IMF (2010b), World Economic Outlook, April, Washington, D.C.

Kumar, M.S. and Woo, J. (2010), Government debt and economic growth, IMF Working Paper, forthcoming, Washington. D.C.

Laeven, L. and Valencia, F. (2008), Systemic banking crises: A new database, IMF Working Paper 08/224, Washington, D.C.

Laeven, L. and Valencia, F. (2010), Systemic banking crises: The new and the old, the good and the ugly, IMF Working Paper, forthcoming, Washington, D.C. 


\section{Monetary implications of the crisis: Dominance at stake*}

\section{Charles Wyplosz**}

\section{Summary}

The paper asks whether the financial crisis is upsetting the struggle for dominance between monetary and fiscal policy. It argues that a crisis is indeed a key moment when challenges to monetary policy dominance are greatest. However, the need to bail out financial institutions blurs the distinction between monetary and fiscal policy. The subsequent shift to public debt stress further weighs on central banks. The paper also discusses the situation when the interest rate hits the zero lower bound.

Keywords: Policy dominance; monetary policy; fiscal policy; European integration

JEL Classification Numbers: E42, E43, E44, E63

* I am indebted to Torben Andersen and Steinar Holden for very useful comments and suggestions and to comments from participants at the Conference on the Fiscal Consequences of the Crisis organized by the Nordic Economic Policy Review in Copenhagen on March 22, 2010.

${ }^{* *}$ Graduate Institute, Geneva and CEPR. 
The potential for conflict between the monetary and fiscal authorities is well established since, at least, Sargent and Wallace (1981). Canzoneri et al. (2001) have formalized this conflict over who determines the price level as a question of dominance.

The issue arises when looking at the single, consolidated public sector budget constraint, where the public sector includes both the general (central and local) government and the central bank. For the public sector to be solvent, current and future revenues must match current and future spending, including inherited debt service. The question is who is ultimately doing the job of satisfying the single constraint? There are three classes of answer. One solution is that the constraint is not satisfied; then the public sector is insolvent, it must default on its debt and the constraint defines the amount of debt that is serviceable. Another solution is that eventually the central bank will be "convinced" to "print money", allowing the government to carry on with its spending and revenue choices. This is the case of fiscal policy dominance. Monetary policy dominance, the last solution, occurs when the central bank will not be responsible for public spending sector solvency. In that case, it is the government branch that will have to change its spending and revenue decisions to bring them in line with the constraint. Crucially, which solution will prevail is never known for sure since the constraint involves both current and future revenues, as far back into the future as we want to see. The resolution of the dominance conflict can only be based on expectations, and expectations can change.

In many ways, this theory has contributed to independence being granted to central banks in a large number of countries. The intent was, and remains, to achieve monetary policy dominance. The fundamental reason is that independent central banks are better protected from the inflation temptation than are governments because the latter face elections.

Following Grilli et al. (1991) and Cukierman et al. (1992), a large literature has confirmed and qualified the general presumption that central bank independence leads to lower inflation at no cost to economic growth. This has led to an emphasis on the role of institutions and the associated link with the exchange rate regime. It came to be recognized that true central bank independence may be difficult to achieve in some countries, and that an exchange rate anchor could be a substitute (Ghosh et al., 2000). The anchor, however, would have to be of the hard variety: a currency board, dollarization or monetary union. This in turn led to the bipolar view (Eichengreen, 
1994; Fischer, 2001), according to which the only stable exchange rate regimes are either those that let the exchange rate float freely or hard pegs. The Washington Consensus went on to advocate full capital mobility with free floats combined with strong central bank independence and, failing that, hard pegs.

The great financial crisis is reopening this debate. The massive increase in public debts of the last two years started as a blessing - governments were bravely and appropriately acting against the threat of a deep and long-lasting regression - but is bound to turn into a quagmire. Several years of deep deficits have boosted public debts. Most policy measures were designed to be temporary in nature. Indeed a large part of the deficits reflected the automatic stabilizers, and will disappear once growth resumes. Yet, the budgets will not return to balance automatically. The size of the effort to stabilize first, and then reverse the debt build-up, is not trivial; sustainability is thus becoming an issue in some cases. The present paper examines the implications of this situation for monetary policy, viewed from the prism of fiscal vs. monetary policy dominance. Could the pendulum swing back towards fiscal policy dominance as governments face challenging times?

To set the stage, the next section briefly quantifies the deficit slippage. Section 2 examines the various battlegrounds for the struggle over dominance. The implications for monetary policy are drawn in section 3 . The last section concludes.

\section{Graphical arithmetic of budget deficits ${ }^{1}$}

The fiscal effort that will be required in the coming years depends on a host of conditions and assumptions that lead to various estimates. In order to keep things transparent, this section presents simple back-of-the-envelope calculations that should provide an idea of the size of the problem. Public debts are currently estimated to rise by some 30 percent of GDP, often more. Assuming that the difference between the interest rate and growth is 2 percent, this implies that the budget balance must improve by 0.6 percent of GDP to

\footnotetext{
${ }^{1}$ For a recent analysis that yields similar conclusions, see IMF (2009).
} 
make up and prevent a destabilization of the debt. ${ }^{2}$ Bringing the debt back down to where it started is more challenging. In principle, this should be spread over time since, from the fiscal policy perspective, the debt build-up can be seen as an unexpected shock. Figure 1 considers two cases, when the reduction is achieved over just 10 years and when it is achieved over 25 years, an ambitious goal already. Depending on the debt level reached, the budget must be brought to a permanent surplus ranging from 2 percent to 6 percent of GDP.

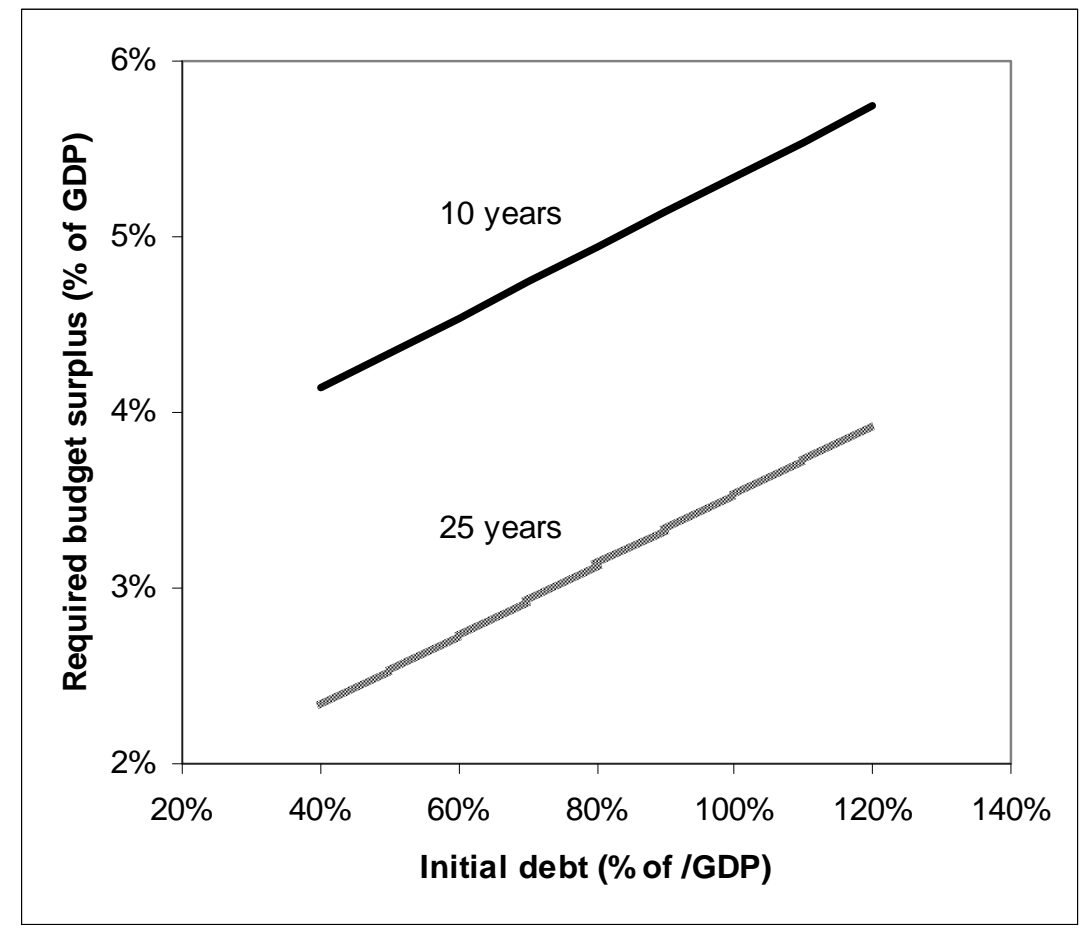

Figure 1. Budget surplus required to reduce the debt by 30 percent of GDP Source: Author's calculation, see Appendix.

That is not all, however. There is some debate on whether growth rates will be durably reduced once the crisis is over, but no one is apparently arguing that GDPs will go back to their pre-crisis trends, at least in the developed

\footnotetext{
${ }^{2}$ Denote the debt-to-GDP ratio as $b$, the budget surplus as a ratio to GDP as $s, r$ as the real interest rate and $g$ as the real growth rate. The debt-stabilizing surplus is $s=(r-g) b$. The calculation looks at the change in this relationship, i.e. $\Delta s=(r-g) \Delta b$., assuming that $r-g=2$ percent.
} 
countries. The baseline case, therefore, describes the recovery and the subsequent years as in the left-hand chart in Figure 2. The right-hand chart describes the second assumption under the baseline case scenario: that, after a temporary increase in outlays - for example on unemployment benefits and various subsidies, public spending resumes its previous trend while tax revenues are tied to GDP and follow a similar path as GDP. The implication is simple. The budget - assumed to be initially to be in deficit for ease of graphical representation - is permanently worsened. If the new trend line lies $2 \%$ below the initial one, relative to public spending tax revenues decline by some $2 \%$ of GDP is it is roughly proportional to income. This will make achieving the surpluses shown in Figure 1 even more challenging.
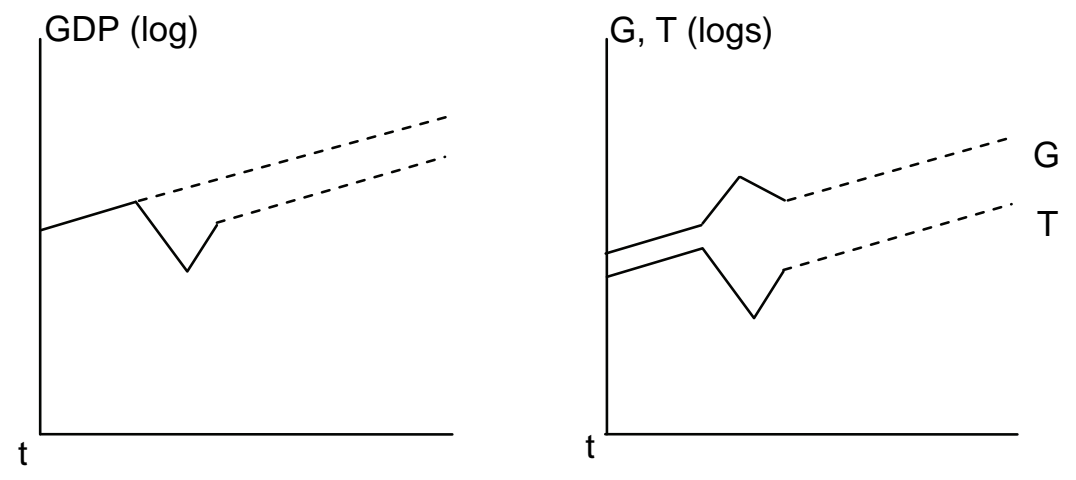

Figure 2. Baseline paths

Yet, this may be unduly pessimistic if we look at past experiences with severe crises. Looking at previous episodes of "bank-centered" financial crises, Reinhart and Rogoff (2008) identify five "big crises”. Since they only look at two years following the crisis, Figure 3 provides a more extended picture of four of Reinhart and Rogoff's Big Five, removing Japan because its economy has not yet really recovered (for reasons that have been much explored). The year indicated in each case is the crisis year as identified by Reinhart and Rogoff. In the two top charts, the GDP recovers its pre-crisis path, computed using the average growth years over the previous 16 years. The situation is less encouraging in the two lower charts. The case of Norway is broadly in line with the baseline assumption in Figure 2. Only in Spain do we see that growth, as opposed to the level, was permanently re- 
duced. However, the mid-1970s correspond to the end of the dictatorship that was followed by deep economic changes.
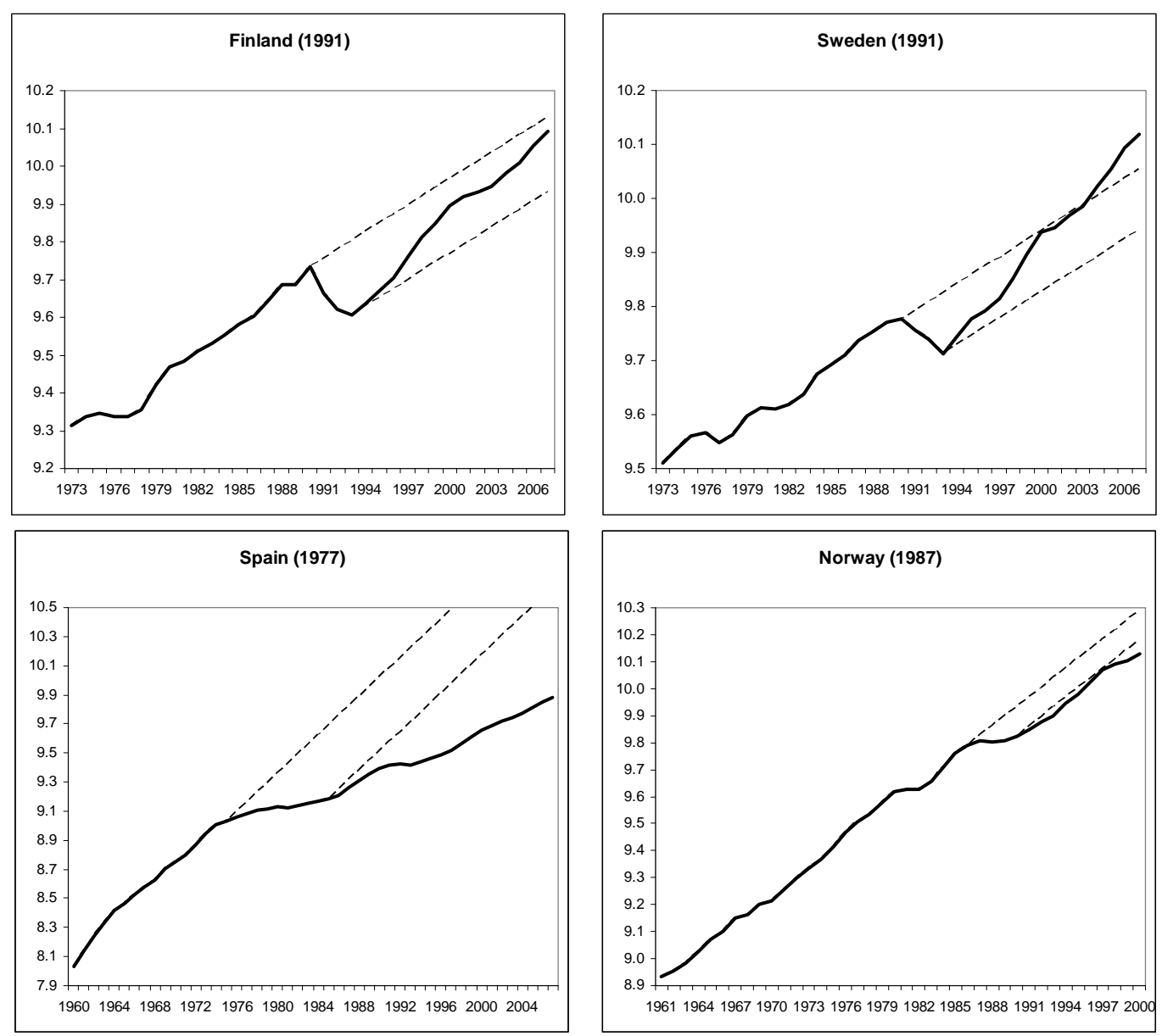

Figure 3. Actual paths of GDP per capita (Logarithm)

Source: Economic Outlook, OECD

The simple calculations underpinning Figure 1 assume that the interest rate exceeds the growth rate by 2 percent. Fast-growing countries face much less demanding conditions. For example, having largely given up on monetary policy with its fixed exchange rate regime, China reacted to the crisis in 2008 with very strong fiscal policy measures, and without any concern for the public debt. 
The conclusion is that, for most countries, there is little doubt that fiscal policies will have to be tightened up relative to the pre-crisis situation. Not only must any deficit be closed, but a further 1 to 2 percent could be needed if the GDP trend is permanently lowered. In addition, a surplus is required to bring the debt down. This can mean a permanent turnaround ranging from 4 to 10 percent of GDP - a challenging effort. The rest of this article examines what it might imply for monetary policy.

\section{The Many Channels of the Struggle for Dominance}

Historically, fiscal authorities that face a daunting task have often found it impossible to resist resorting to inflationary money-financing. This is the fiscal policy dominance assumption. Given that most developed countries have granted them a high degree of independence, central banks are unlikely to be directly and openly pressed to absorb public debts through inflation. The struggle for dominance will have to be more subtle. The new game will shape up as indirect pressure that could lead some central banks to reluctantly adopt policies that they would rather not follow. Three recent examples come to mind. First, Governor Bernanke has publicly admitted that the US Federal Reserve (the Fed) lent to Bear Stearns and AIG, for amounts totaling 5 percent of the Fed's balance sheet, "with great reluctance under extreme conditions" (Bernanke, 2010). Second is the emergency attendance of President Trichet to a mid-February 2010 European Council that pledged their (undefined) support for the embattled Greek government, apparently with his full backing. Presumably he was trying to deflect any suggestion that the ECB might do the job itself. But then, the third example is the May decision of the ECB to buy outright - as opposed to agree to repurchase agreements, as it had so far insisted on doing - public debts that are frowned upon by the markets. Coming a day after EU countries agreed to put up $€ 500$ billion (5\% of the Union's GDP) to guarantee these same debts, the ECB decision looks suspiciously like a case of loss of monetary policy dominance. $^{3}$

These are dramatic and rare events. A natural question is whether armflexing between the two branches of government can operate more discretely

\footnotetext{
${ }^{3}$ This point is further developed in Wyplosz (2010).
} 
through indirect channels, such as the interest and exchange rates and through financial markets.

\subsection{Interest rates}

As policy instruments and channels of transmission, interest rate movements are of primary concern to central banks. Can they be an Achilles' heel in the struggle for dominance? The idea is that government profligacy leads to higher interest rates, which in turn encourages central banks to be more dovish. Both channels need to be examined.

Textbook models tell us that a budget deficit increases the interest rate, but textbooks ignore many details that matter a lot. The short end of the term structure is obviously closely guided by the central bank. Long-term interest rates, on the other hand, respond to much more than monetary policy. They combine inflationary expectations and, indeed, the impact of public borrowing - both the issuing of long-term bonds and expectations of future debt issues. On the other hand, when financial markets are internationally integrated, real interest rates reflect domestic conditions only to the extent that there exist risk premia, and that the exchange rate is expected to change over the relevant horizon.

Given all these influences, it is not surprising that the empirical literature on the real interest rate effects of fiscal policy is ancient, vast and controversial. Much of it has been looking at the US, which is a special, possibly unique case. Indeed all other countries are small relative to the financial markets, and their interest rates tend to be determined relative to the world key currency, the US dollar.

While direct tests fail to turn up evidence, the more recent literature recognizes the possibility that fiscal policy effects on the long-run real interest rate depends on the size of the existing debt, the circumstances (including current budget deficits or surpluses), institutions, and a host of expectations concerning both fiscal policy and financial markets. There is, maybe, the beginning of a consensus.

In a recent study of the US case, Laubach (2009) reports that a one percentage point increase in the deficit/GDP ratio raises the interest rate by 25 basis points, and that a similar increase in the debt/GDP ratio drives the interest rate up by 3 to 4 basis points. Looking at OECD countries, IMF (2009) reports estimates of 20 and 5 basis points, respectively. Both studies 
confirm earlier results that these effects are not linear, rising sharply as the debt increases. The much larger effect of the deficit can be seen as a surprise since theory typically considers that it is the debt that should matter. Then a deficit, which can be temporary and therefore countered by a subsequent surplus, should impact less the interest rate. A plausible interpretation is that, on the contrary, markets tend to see deficits as permanent, or long-lasting enough to recurrently add to the debt. If that interpretation is correct, long real rates should first rise while deficits are large and then decline as fiscal stabilization takes place.

Real Short-Term Interest Rate

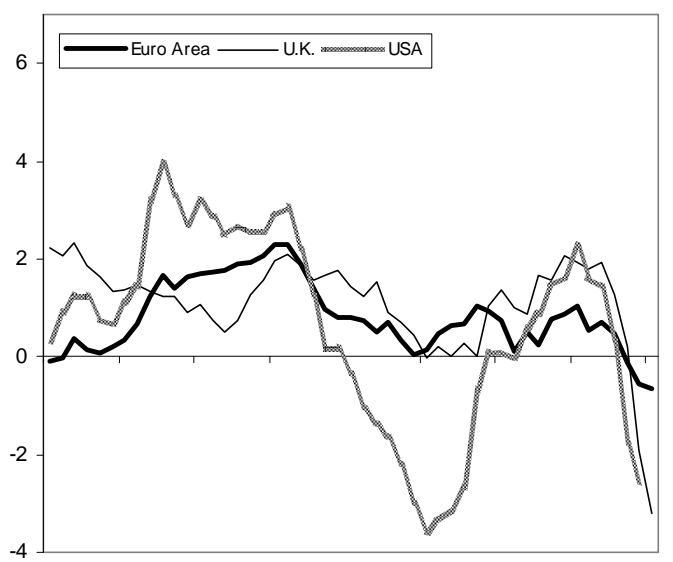

2006M1 2006M7 2007M1 2007M7 2008M1 2008M7 2009M1 2009M7 2010M1
Real Long-Term Interest Rates

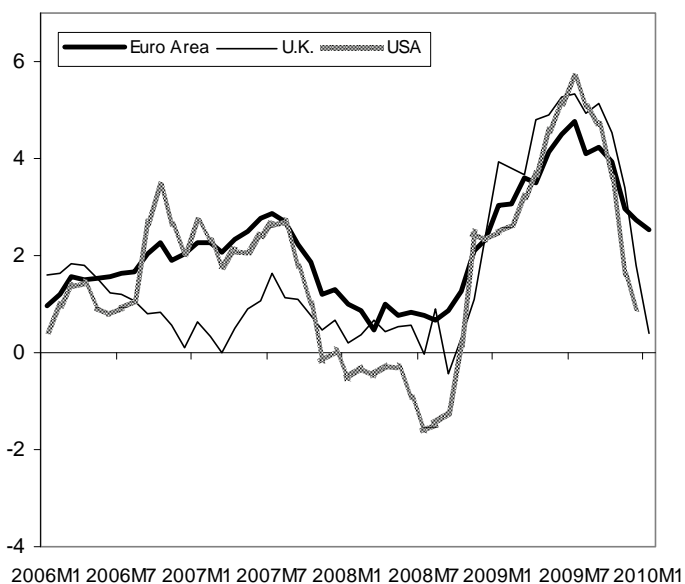

Figure 4. Real interest rates

Sources: International Financial Statistics and central bank websites

Notes: Short-term rates are EONIA (euro area), the Fed Funds (US) and the Interbank rate (U.K.). Long-term rates are 10 year maturity spot rates on government instruments. Current inflation (relative to the same period a year before) is used to compute real rates.

The recent pattern is puzzling at first blush. According to the previous estimates, budget deficits widening by 5 percent to 10 percent of GDP and debts rising by 30 percent should have raised the real interest rates by 2 percentage points, at least. Figure 4 shows that real long-term rates did rise a lot after September 2008, when governments realized that the crisis would be severe enough to warrant exceptional fiscal policy action. This is also when, for the same reason, central banks started to slash the short-term nominal interest rates all the way to the zero lower bound. Yet, the real short-term interest rate rose, as Figure 4 shows, because inflation quickly declined (from ele- 
vated levels) to become negative. It is thus unclear whether the real longterm rates rose because of market concerns with historically high budget deficits and public debts. At any rate, once inflation emerged from negative territory during 2009, both short and long-term real rates declined to low levels.

It seems therefore that real interest rate movements are dominated by swings in inflation rates and, possibly, by monetary policy, including repeated central bank statements that the policy rates will remain very low "for a long period". A way of accounting for both factors is to look at the yield curve. The evidence presented in the leftmost chart of Figure 5 seems to support the presumption that deficits and debts move interest rates up. The rightmost chart, however, shows that nominal long-term rates have declined since the start of the crisis. Together, the two charts imply that the nominal long-term rates have declined by less than the short-term rates. This last observation is troublesome for the view that budget imbalances have played a role because long-term rates always move less than short-term rates. 4 Thus, it is only to be expected that the yield curve steepens when the central bank reduces its policy rate. Much the same - qualitatively and quantitatively - occurred when interest rates were reduced in 2001-2, a period when deficits rose by considerably less.

A plausible conclusion is that the large increases in both public deficits and debts have not yet fully registered in real interest rates. It has been suggested that this is due to a "flight to quality" in the midst of the financial crisis. In this view, government bonds are seen as safer than most privately issued papers. An indication that this is the case is the much-discussed fact that markets have started to discriminate among public debts, not all of them being seen as a safe haven. It follows that long-term rates should rise, possibly considerably, once markets recover risk appetite. The one reason to doubt this interpretation is that risk appetite, as measured by the VIX index, has declined considerably since April 2009, without any increase in government bond rates or in the risk premia on suspicious public debts.

\footnotetext{
${ }^{4}$ The common interpretation is the expectations hypothesis, which implies that long-term rates are averages of current and future short-term rates, along with the view that short-term rates tend to regress to their means.
} 

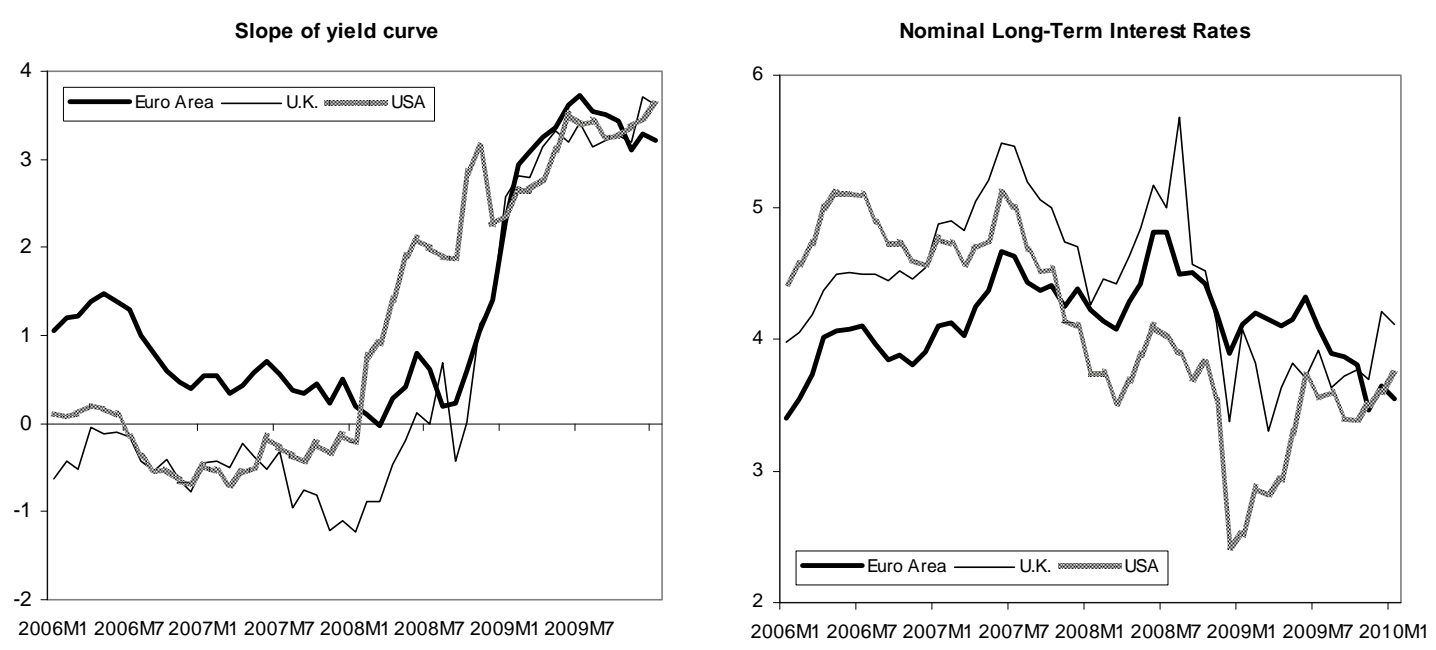

Figure 5. Slope of the yield curve and nominal rates

Sources: IFS and central bank websites.

Note: The slope is the difference between 10 year bond rates and the short-term rate, see Figure 4 for details.

While the impact of fiscal policy on interest rate is at best limited, there remains the question of the influence of interest rates on central banks. As previously noted, central banks can control the short-term rates, which have limited effects on the economy, the exception being countries like the UK where bank lending conditions are indexed on these rates. The more important interest rates are medium to long rates that represent the bulk of borrowing, and thus affect spending by households and firms. Imagine that large deficits lead to an increase in the long-term interest rate. This has a contractionary effect, indeed it is the presumed channel for the textbook crowdingout effect. Would that lead central banks to become more accommodative than otherwise?

Central banks insist that they do not react mechanically to events. This implies that a central bank will not react automatically to a long-term interest rate increase. Its decision will presumably involve the whole of range of its usual concerns. Even in the mechanical description of the Taylor rule, central banks only respond to expected inflation and expected output. In this view, the central bank will respond to the interest rate change in a way that upholds its inflation and output objectives. As long as the central bank is 
independent, it is quite unlikely that monetary policy dominance can be challenged via the interest rate.

\subsection{The exchange rate}

The exchange rate is another important concern for central banks. Inasmuch as fiscal policy affects exchange rates, this variable can be seen as another battleground in the struggle for dominance when it is freely floating. ${ }^{5}$ When it is fixed and adjustable, fiscal dominance is established, as discussed below.

The link between fiscal policy and the exchange rate is all but clear. Textbook models in the IS-LM tradition predict that, when the exchange rate is freely floating, a fiscal expansion is met by an exchange rate appreciation as the expansion raises the demand for money and prompts capital inflows. This appreciation undermines the effectiveness of fiscal policy. As a result, the central bank is on the spot since it alone can prevent the appreciation and thus support fiscal policy. ${ }^{6}$

The empirical literature is very limited and yet contradictory. The most recent contribution by Bénétrix and Lane (2009), who estimate the impact of fiscal policy shocks on the real exchange rates for a panel of 11 euro area countries and for a panel of four non-euro area countries, finds opposite effects between individual euro area countries that have de facto fixed exchange rates amongst themselves (raising public spending leads to a real appreciation) and flexible exchange rate countries (the real exchange rate depreciates). A plausible conjecture is that, as with the interest rate, expectations play a crucial role.

Of independent interest is what happened since the beginning of the crisis, which cannot yet be subjected to formal testing. Figure 6 simply relates the change in the real exchange rate from June 2007 to October 2009 (last available observation) to the change in public debts from 2007 to 2009. For all OECD countries, treating the euro area as a single observation, the left-

\footnotetext{
${ }^{5}$ This is the one potential limit to the ECB's otherwise total independence. The Treaty (Art.219) opens the door for governments to "formulate general orientations" on exchange rate policy. The ECB, naturally, insists that this only concerns formal exchange rate arrangements while some governments have made comments on the level of the exchange rate.

${ }^{6}$ Neo-classical models predict the opposite because private wealth is reduced by future tax liabilities and prices decline. Price rigidity, as in New Keynesian models, undermines this effect, but these models have little to say about money and capital flows.
} 
most chart shows that the association is negative, but that the partial correlation coefficient is not significant. Focusing on euro area member countries in the right-hand chart, the partial correlation is significantly negative. While this runs against the results reported by Bénétrix and Lane (2009), it must be emphasized that partial correlations do not deal with causality. In addition, the situation remains very fluid and the pattern may change before we can conduct forensic studies of the crisis. For example, the euro has depreciated by some 10 percent since the last observation, reportedly because of market concerns with some euro area member countries public debts.

All countries (Euro Area as one unit)

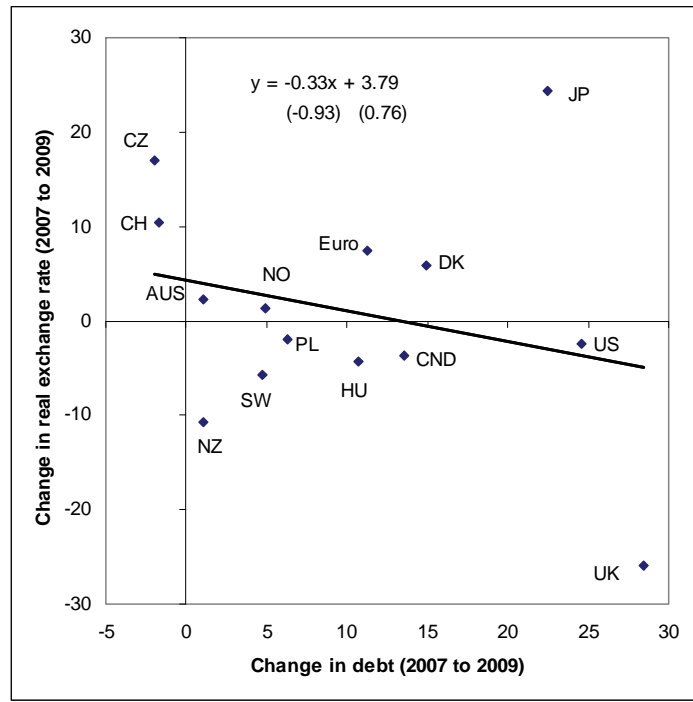

Euro Area Member Countries

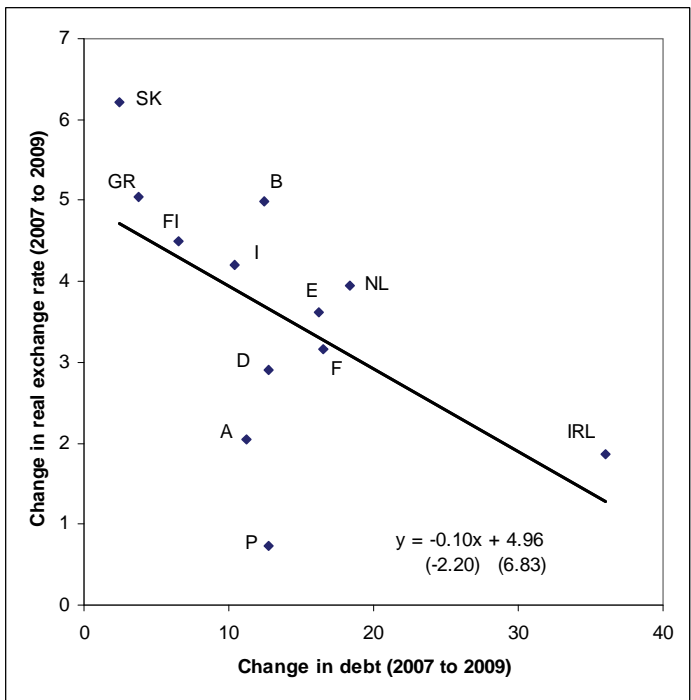

Figure 6. The real exchange rate and public debts in the crisis in OECD countries Changes from 2007 to 2009

Sources: International Financial Statistics, IMF and Economic Outlook, OECD

Notes: The real effective exchange rate is deflated by $\mathrm{CPI}$, change is in percent. Debt to GDP ratio, change in percent of GDP. An increase is a real appreciation.

The period since 2007 is relatively short, especially regarding price movements. Were real exchange rate movements driven by nominal changes, as is usually the case, see e.g., Rogoff (1996)? Looking at nominal effective exchange rates, instead, reveals no correlation with debt ratios for the sample countries of the left-hand chart in Figure 6. Looking at the euro area member countries, the relationship is strongly positive, but it disappears when two outliers, Austria and Ireland, are excluded. Since all these countries share the 
same currency, differences in effective rates reflect the composition of trade: Ireland's effective rate appreciated because Britain is an important trade partner and the Sterling depreciated by some 25 percent; while Austria's effective rate remained virtually unchanged, reflecting the importance of its trade links with Germany.

All in all, there is little evidence of any systematic effect. Assuming that there is one, what impact would it have on a central bank? Pretty much as with the interest rate, the central bank is likely to focus on the impact of the exchange rate on the expected evolution of inflation and the output gap, i.e. it will react to fiscal policy but with the intention of achieving its usual objective(s). The situation is radically different when the exchange rate is pegged since, in this case, monetary policy is not an autonomous instrument and the central bank is not truly independent. Not surprisingly, fiscal policy then is likely to "force" the central bank to change its stance as it intervenes in the foreign exchange market to uphold the declared parity. Still, the parity cannot be maintained if fiscal policy keeps imparting a bias in either direction. With parity adjustments, however, fiscal dominance is established.

The distinction between fixed and flexible exchange rates is not as clear cut as it seems. Because the exchange rate directly affects its objectives inflation and output - a central bank is unlikely to ignore its evolution. Inasmuch as appreciation reduces inflation and threatens to bring to negative territory, or hurts growth, or both, a central bank may find it necessary to adopt a more expansionary stance. Put differently, in a small open economy where the exchange rate is an important variable, the dominance issue is wide open. This observation applies to the Nordic countries.

\subsection{Markets as referees}

The previous section looked at "normal” effects of fiscal policies. However, financial markets occasionally react violently, which leads to crisis situations. Furthermore, crises are often contagious, as shown in Eichengreen et al. (1996) and Kaminsky and Reinhart (2000). Once markets have detected a vulnerability in the case of one country, they soon look around for similar situations. In this event, the crisis spreads to countries that would probably not have been noticed without the initial crisis, an instance of self-fulfilling crises. Examples of this phenomenon have accumulated in recent years. This happened to Finland and Sweden in the early 1990s. The Tequila Crisis also 
spread through South America in 1995 following a successful attack on the Mexican peso. In 1997-98, one South-East Asian country after another faced heavy hardship following the Thai Crisis. Soon thereafter, a crisis in Russia spread to other former Soviet Union countries and, apparently, to Norway and Brazil as well. The 2001 crisis in Argentina again shook South America. Now we see the Greek crisis threatening to move to other euro area countries.

In all of these cases, fiscal indiscipline is a center stage. We know that self-fulfilling crises occur in the presence of some vulnerability, quite often the fiscal situation. Markets start worrying about a default and, by running on a country's currency, they effectively provoke the default. The generally massive depreciation that ensues soon leads to large price increases. Even though the nominal exchange rate often partly recovers once the panic has come to an end, price increases are permanent - in fact the real exchange rate is usually restored to its pre-crisis level. Unless it wants to force a revaluation and a price decline, the central bank is compelled to ratify the situation, in effect increasing the money supply. Seigniorage and debt depreciation represent a case of fiscal policy dominance, and markets running on currencies make this possible.

\section{Monetary policy after the crisis}

The new world in which central banks will operate differs from the pre-crisis world in many ways. The inflation-targeting framework has been shaken, but probably not fatally wounded. The old myth that central banks could exercise discretion in lending-in-last-resort operations has been removed. Large public debts may raise the long-term interest rates for a decade or two, steepening ceteris paribus the yield curve. Finally, fiscal policy could be impaired in many countries. This section takes up these issues.

\subsection{Is inflation targeting passé?}

While inflation targeting has become the standard during the 2000s, a number of objections have been raised. The ECB never acknowledged that it was a de facto inflation targeter, because it famously stood by the Bundesbank two-pillar legacy, which pays some respect to monetary aggregates (Issing, 
2001; Beck and Wieland, 2007). Given its legal brief, the Fed so far also feels that it cannot admit to practicing inflation targeting. The Bank of Japan has also steadfastly refused to admit any strategy. A small number of papers had also argued that central banks should not ignore asset price developments, see e.g., Cecchetti et al. (2000).

Once the crisis erupted, these criticisms have quickly resurfaced. Leijonhufvud (2009) offers a scathing attack on inflation targeting, which he views as simplistic. This point, however, ignores much of the more recent literature on complexity and robust rules, for example Orphanides and Williams (2007). More central is the question of whether monetary aggregates were providing important information that too many central banks had been convinced to ignore or downplay. As far as I know, this has not yet transpired into scholarly work, but some researchers have started to argue that the crisis has vindicated the ECB strategy.

The debate between and the ECB and its critics is muddled by extraneous side considerations. One of them is the question of whether money matters for the transmission of monetary policy. The view that it does not has been convincingly advanced by Woodford (2008), but the crisis has exposed its limits. In particular, the assumption that markets are complete removes financial considerations from the models used to examine the channel of monetary policy. The lesson from the crisis, that credit growth is a useful indicator, is unmistakable and has been taken on board in new research, see Curdia and Woodford (2009). The other debate is whether looking at monetary aggregates is incompatible with inflation targeting.

This second debate is merely definitional. For many years, Svensson (1999) and others have argued that the inflation targeting strategy is meant to be flexible. This means that credit growth can be looked at, even responded to, if needed. The same argument is now used by Svensson (2010) to argue that asset price movements can readily be incorporated in the strategy. Before the crisis, many inflation-targeting central banks - for instance the Bank of England - strenuously and explicitly refused to admit that they should be influenced by asset price inflation. ${ }^{7}$

The question is whether the flexible definition of the strategy does not become vacuous when it is made to accommodate more concerns. By stating

\footnotetext{
${ }^{7}$ Central banks that did not officially adopt the inflation targeting strategy, such as the Fed and the ECB, also rejected any direct role for asset prices over and beyond their impact on inflation and output.
} 
that it looks at everything that matters for future inflation and economic growth, a central bank does not commit to inflation targeting. The strategy requires a lot more: identifying a target inflation rate and an acceptable range around it, publishing forecasts of inflation and the output gap at the policy horizon - and acknowledging the horizon - and a clear statement of how the central bank views the trade-off between inflation and output over the relevant period. Credit growth and asset prices influence all of the above so, in a way, their influences must be part of the strategy if the forecasting exercise is conducted correctly. What is at stake is whether the central bank is ready to acknowledge that credit may be growing too fast or that asset prices are embarked on a bubble-like path, and to explain what policy conclusion it draws. In the period leading up to the crisis, both phenomena were under way in many countries and yet most central banks chose not to discuss the situation. Most, in fact, consciously decided not to modify their policies.

The next issue is what to do about unduly rapid credit growth or asset price inflation. Early critics of the inflation-targeting strategy suggested that the interest rate should be raised above what the relevant forecasts would suggest because of the risk of crisis (Cecchetti et al., 2000). The counterargument was that sharply raising the interest rate was sure to precipitate a slowdown, possibly even a recession, while diagnosing excessive credit growth or an asset price bubble was a highly uncertain undertaking. The emerging post-crisis consensus, as stated in Svensson (2010), is that it is incumbent upon central banks to detect such potential sources of crisis, but that the policy response is not to raise the interest rate. Excessive credit growth or asset price bubbles are the consequences of market failures, possibly exacerbated by inappropriate regulation. The second best principle is to use the instrument that most directly addresses the failure. In general, the interest rate is unlikely to be a second best instrument. For example, the fast increase in subprime loans, arguably the cause of the crisis, involved market failures (the originate and distribute model, which separates risk-taking and risk-bearing, and a severe information asymmetry uncorrected by adequate consumer protection), misguided market interventions (Fannie Mae and Freddy Mac), and inadequate worldwide bank supervision (Basel 2 did not catch the shadow banking system). Righting some of these wrongs in good time could probably have averted the crisis while raising the interest rate, even very strongly, would probably have brought the crisis forward. 
The implication is that the inflation targeting strategy has broadly survived the test, but that some adjustment is needed. Central banks no longer can pretend that asset prices and developments on the credit market are merely indicators to be factored in when making inflation and output forecasts. They must acknowledge that they share responsibility for financial stability with regulators and supervisors. They should continue to use the interest rate to target inflation taking account output developments as in the now-traditional flexible version of the strategy, but they must recognize that there are times when threats to financial stability warrant an explicit inflection. This can be rationalized as a fat-tail phenomenon where expected inflation and output gap no longer appropriately describe the situation. At the same time, central banks should not take full responsibility for financial stability because the most adequate instruments belong to government agencies.

\subsection{The Zero Lower Bound}

The Japanese experience and a temporary deflation scare in 2003 among OECD countries have brought back the old fear of a liquidity trap (Krugman, 2003). It has finally happened among many of the advanced economies when interest rates were brought to the zero lower bound. One issue is whether monetary policy loses its effectiveness when the interest rate cannot be lowered any further. Another issue is what can be done when the bound is reached. A third issue is how to avoid the zero lower bound.

The effectiveness issue boils down to preventing a liquidity trap. With interest rate stuck at zero, the central bank is left with two instruments: the quantity of money and the management of expectations. It is very unlikely that expectations can be managed without action, as some central bankers sometimes seem to believe. The question, then, is whether pushing more money into the economy has an effect at all or whether it is simply shelving it in trap.

The Bank of Japan's experiment with quantitative easing has drawn mixed, mostly negative appraisal, see Ito (2009). Part of the reason is that Japanese banks were allowed to not fully recognize their losses and to remain undercapitalized. As a result they hoarded liquidity instead of lending. The Bank of Japan then moved to flatten the yield curve by buying longdated securities, and apparently achieved to do so. Yet, for all these efforts, a 
decade later inflation remains nil or negative. This shows that massive quantitative easing can be ineffective in the presence of a liquidity trap.

Two proposals have been advanced for trying to exit from a liquidity trap. Svensson (2003) advocates unsterilized foreign exchange market interventions. The hoped-for exchange rate depreciation should generate both inflation and increased demand for domestic goods. This makes good sense when just one country is caught in a liquidity trap, like Japan in the 1990s; but it cannot be used when a large number of countries are simultaneously trapped. More generally, it raises a serious beggar-thy-neighbor issue that requires some international agreement (informal to start with). Buiter and Panigirtzoglou (2003) advocate imposing a negative interest on money, including cash. This would lower the real interest rate but it remains unclear whether it would also break the negative sentiment that deters spending by firms and households in a recession situation. In addition, the costs of organizing such a scheme are bound to be large. Except for a couple of foreign exchange interventions in 2009-10 by Australia and Switzerland, none of these two solutions have been implemented.

It is far too early to pass judgment on the effectiveness of quantitative easing efforts conducted by several central banks in 2009. Section 3.1 makes the point that long-term interest rates did not rise as large budget deficits opened up. One possible reason is that quantitative easing, in particular the willingness of central banks to hold long-dated assets, has been effective. On the other hand, bank credit has not expanded much, but careful research is needed to determine whether it is demand or supply that has acted as a force of restraint.

The crisis has brought home the view that liquidity traps should not be confined to textbook footnotes or to the economic history of the 1930s. It seems - again, this point will have to be formally investigated - to confirm the lesson from Japan, namely that liquidity traps are potentially dangerous because we do not have fool-proof instruments to exit once we are caught in one of them. Obviously, we now need to think how monetary policy should be adjusted to reduce the incidence of liquidity traps.

The main suggestion thus far is that central banks should normally keep the nominal interest rate far enough from the zero lower bound. Since the real rate cannot permanently differ from its natural level, the only way to widen in normal times the distance of the nominal rate from zero is to raise the inflation target. This reasoning, which can be found in Begg et al. (1998) 
and Gerlach et al. (2009), has recently attracted attention with Blanchard et al. (2010), who consider 4 percent as a reasonable inflation target.

The idea of aiming at a higher inflation rate during normal times to reduce the odds of a deflation obviously runs again the current orthodoxy. Yet, in many advanced countries, inflation has moved close to, or indeed into, negative territory twice during the recent low inflation period. The question is whether the trade-off, accepting higher average inflation to limit the risks of deflation, is meaningful. A back of the envelope calculation can be done as follows. The Taylor rule provides the interest rate $i$ that the central bank sets, given foreseen inflation $\pi$ and output gap $x$, given the natural real rate $r$ and the inflation target $\pi$ :

$i=r+\bar{\pi}+a(\pi-\bar{\pi})+\beta x$

As is well known, the rule provides a decent description of what most central banks do. We can simulate the interest rate that the central bank would have set if it had followed the Taylor rule. Assuming for simplicity that the resulting interest rate is normally distributed, by observing its mean and standard deviation, we can infer the probability of hitting the zero lower bound. Further assuming that the implicit inflation target has been constant over the sample period, we can change $\pi$ and compute the new mean and the associated probability. An even simpler procedure is to simply observe the actual interest rate, assume that it is normally distributed, and infer the probability that it be negative.

The results of this calculation are reported in Table 1, and are based on the US experience from 1970 to 2009. The boldfaced row corresponds to actual annual observations. Columns (2) and (3) show the mean and standard deviation of the policy interest rate i. Column (4) reports the probability that $\mathrm{i}<0$, which stands at 3.4percent or once every 30 years. Over the last 40 years, the Fed reached the lower bound once and came close to it another time. Columns (6) to (8) provide the same information where the interest rate is now simulated using the Taylor rule with the conventional values $\alpha=1.5$ and $\beta=0.5$ and with $r$ such that the average of the simulated nominal interest rate average is the same as the sample average of the actual rate. The Taylor rule leads to a more activist policy, and therefore to a higher probability of bringing the interest rate to zero. Many papers show that an inertial 
version of the rule tracks the actual interest rate more closely. In the present case, this would deliver results closer to those shown in Column (4), thus offering less of an alternative to these results.

Table 1. Probability of hitting the zero lower bound

\begin{tabular}{|c|c|c|c|c|c|c|c|c|}
\hline \multirow[b]{2}{*}{$\begin{array}{l}\text { Average } \\
\text { inflation }\end{array}$} & \multicolumn{4}{|c|}{ Actual interest rate } & \multicolumn{4}{|c|}{ Taylor rule interest rate } \\
\hline & Mean & $\begin{array}{l}\text { Standard } \\
\text { deviation }\end{array}$ & $\begin{array}{r}\text { Probability } \\
\text { (constant } \\
\text { SD) }\end{array}$ & $\begin{array}{r}\text { Probability } \\
\text { (variable } \\
\text { SD) }\end{array}$ & Mean & $\begin{array}{l}\text { Standard } \\
\text { deviation }\end{array}$ & $\begin{array}{r}\text { Probability } \\
\text { (constant } \\
\text { SD) }\end{array}$ & $\begin{array}{r}\text { Probability } \\
\text { (variable } \\
\text { SD) }\end{array}$ \\
\hline (1) & (2) & (3) & (4) & (5) & (6) & (7) & (8) & (9) \\
\hline 0 & 1.7 & 2.8 & $30.7 \%$ & $27.0 \%$ & 1.7 & 3.8 & $35.3 \%$ & $32.3 \%$ \\
\hline 1 & 2.7 & 2.9 & $21.3 \%$ & $17.6 \%$ & 2.7 & 3.9 & $27.6 \%$ & $24.3 \%$ \\
\hline 2 & 3.7 & 3.1 & $14.1 \%$ & $11.3 \%$ & 3.7 & 4.1 & $20.8 \%$ & $18.0 \%$ \\
\hline 3 & 4.7 & 3.2 & $8.4 \%$ & $6.8 \%$ & 4.7 & 4.3 & $15.1 \%$ & $13.3 \%$ \\
\hline 4 & 5.7 & 3.3 & $4.8 \%$ & $4.2 \%$ & 5.7 & 4.4 & $10.6 \%$ & $9.7 \%$ \\
\hline 4.6 & 6.3 & 3.4 & $3.4 \%$ & $3.4 \%$ & 6.3 & 4.6 & $8.6 \%$ & $8.6 \%$ \\
\hline 5 & 6.7 & 3.6 & $2.5 \%$ & $3.0 \%$ & 6.7 & 4.8 & $7.1 \%$ & $7.9 \%$ \\
\hline 6 & 7.7 & 3.7 & $1.2 \%$ & $1.9 \%$ & 7.7 & 5.0 & $4.6 \%$ & $6.0 \%$ \\
\hline
\end{tabular}

Source: Fed Funds rate and US CPI inflation are from International Financial Statistics; the US output gap is from the OECD Economic Outlook. Sample period: 1970-2009.

Note: "Constant SD" takes the actual standard deviation (boldfaced in column (3) or (7) to compute the probability; "Variable SD" adjusts the standard deviation to a different mean as shown in column (3) or (7), where a raising the mean by unity is accompanied by a $4 \%$ increase in standard deviation, see Rother (2004).

The other rows examine what would have been the case if inflation had been lower and, using Fisher's principle, the nominal interest rate would have been lowered accordingly. For example, the third row corresponds to an average inflation rate of 2 percent, which is assumed to be the central bank target, successfully achieved on average. Since this inflation is 2.6 percentage points below the actual sample average, the average interest rate is assumed to be lower by the same amount. Column (4) indicates that the probability to hit the zero lower bound increases considerably to 14.1 percent, i.e. one year out of seven. Similar results are obtained with the Taylor rule simulation in Column (8), where it is assumed that the target inflation rate is the same as the average rate.

It should be emphasized that this crude back-of-envelope calculation is presented for illustrative purpose. Many assumptions are clearly dubious. It is known, for example, that the interest rate distribution is skewed. In addition, the (implicit) target inflation rate must have varied quite a bit over the sample period. It is also known that inflation and interest volatility rises with the inflation level. Columns (3) and (7) account for the latter effect, using the volatility elasticity as computed by Rother (2004). The implied prob- 
abilities are shown in Columns (5) and (9). As expected, the volatility effect reduces the probability of hitting the lower bound as the inflation rate declines and, conversely raises it as inflation increases. The effect is found to be too small to offset the role of the distance from the inflation target from zero.

With all the caveats required when interpreting these results, the exercise suggests that the tradeoff exists. Raising very moderately the target (and average) inflation rate probably significantly improves the odds of escaping the zero lower bound.

\subsection{Implications of too-big-to-fail}

Just one event, the collapse of Lehman Brothers, has changed part of the Bagehot doctrine: central banks cannot decide whether to intervene or not when a systemically important bank is collapsing. The implication is that financial institutions too big to fail have a de facto guarantee of bailout in case they fail. The further implication is that every financial institution has a strong incentive to become too big, or too interconnected to fail.

The crisis has also amply illustrated the old mantra that central banks do not have the time, or even the ability to determine whether a financial institution is suffering from illiquidity or from insolvency. In fact, as shown by Kiyotaki and Moore (1997), the distinction may well be meaningless when illiquidity leads to fire sales and to sharply declining asset prices.

The threat of a financial meltdown represents another ground for the battle over dominance. Because one of their duties is to ensure a smooth functioning of financial markets, central banks are committed to "do something" when banks and key financial institutions are in a precarious situation. At the very least, they must provide liquidity. At worst, they must rescue banks. In principle, a bank bailout is a fiscal responsibility, but governments can sit out for a while, which central banks cannot, because they are engaged in the markets in continuous time. The resulting blurring of the distinction between fiscal and monetary duties is a threat to monetary policy dominance.

Because banking crises are so dangerous, central banks may be tempted to err on the side of easier policy when in doubt or when the situation becomes dangerous. This temptation is very different from the earlier argument in favor of a higher inflation target. In the former case, the central bank continues to enforce its rule whereas in the latter case it deviates from its chosen 
strategy in the hope of avoiding forced lending in last resort. This can be seen as another dominance struggle, this time between central and commercial banks.

Both forms of dominance struggle explain that central banks have a huge stake in improving financial regulation, and in having it rigorously enforced. Whether the proper model is to entrust the regulation and supervision of individual institutions to the central bank is a complex issue that does not belong to a paper on monetary policy, except to note that it would not necessarily strengthen central bank dominance over both the government and large financial institutions.

The proper response to the now-exposed obligation to lend in last resort is to deal directly with the moral hazard that it creates. Macroprudential regulation and supervision is now seen as probably the second best policy response, see Brunnermeier et al. (2009). Likely to be implemented in the near future, macroprudential supervision squarely belongs to central banks. Analytically, it involves aggregating individual bank-level information, a fairly complex procedure, and linking this information to macroeconomic and financial developments. The skills for this work are in central banks. Of course, other agencies could acquire these skills, but they would anyway need to agree with central banks about the macroeconomic developments.

\subsection{Steeper yield curves}

It was argued in Section 2.1. that high debts are likely to eventually lift longterm real interest rates, corresponding to the amount of long-term public debt that will have to be held by the private sector. If this assumption is correct, it means that in the coming years the yield curve will be ceteris paribus steeper than before the crisis. This effect must be compared to other possible changes likely to also affect the long end of the yield curve. Partly in response to higher real interest rates, saving behavior by household and in emerging market countries could increase, thus partially offsetting the debt effect. The overall impact of the crisis may therefore be limited.

Still, assuming that the yield curves become steeper, will that affect monetary policy? For a given short-term policy interest rate, policy will be more restrictive than when the curve was steeper. This can be corrected most easily and should not create any difficulty for central banks except that it could raise the probability of reaching the zero lower bound. Another policy 
response is for central banks to continue the practice, started during the crisis, of acquiring long-dated securities.

\subsection{Impaired fiscal policies}

Large public debts are likely to impair fiscal policies. Rolling back debts will force governments to aim at structural surpluses, imparting a contractionary bias until this is achieved. In addition governments are likely to be reluctant to reopen deficits once they have closed them. If this conjecture is correct, monetary policy will be seen as the main, if not only, macroeconomic policy instrument.

This is not a large change, since conventional wisdom before the crisis already held that monetary policy is the countercyclical instrument of choice: for a number of reasons. Decisions can be taken fast and are less subject to political motives than fiscal policy. The interest rate instrument is simpler to use than changing taxes or public spending. The effects are better known, both theoretically and empirically.

Pushing ever more responsibility onto central banks does not necessarily affect dominance. What is important, though, is that monetary policy remains effective under most plausible conditions. This issue is treated in Section 2.2.

\section{Conclusion}

The crisis is leaving most but not all advanced countries with historically high debt levels. As governments need to focus on fiscal discipline, they may rely on central banks to deliver countercyclical policies and possibly even weigh on them to provide relief through inflationary finance. The monetary policy dominance regime in place is therefore under threat. Yet, the biggest threat to monetary policy dominance may well come from the current financial system, that it has become clear that central banks have no choice but to bail out systemically important financial institutions. How can central banks react?

With strong central bank independence, the debt is unlikely to be monetized. Whether long-term real interest rates will be permanently higher or not depends on a host of factors, not just about public debts. Anyway, central 
banks have learned how to intervene along the yield curve. It may well be that fiscal policy will not play much of a countercyclical role, but it has rarely done so in recent years, so little is changed.

The real challenges for central banks lie elsewhere. First, the 2000s have revealed the danger of disinflation when inflation targets are set very low. ${ }^{8}$ The dominating current sentiment, that inflation should not be allowed to reappear, makes it difficult to consider higher inflation targets. But the issue must be debated in earnest.

The second challenge is to design regulations that reduce the too-big-tofail syndrome and to carry out strict supervision. Central banks must be involved, and possibly in charge of macro-prudential supervision. Serious consideration could even be given to attribute micro- prudential supervision of central banks. There are solid arguments to avoid dragging central banks into this domain but the generalized failure of supervision agencies before the crisis - and, in some countries, after the crisis - means that there should not be any sacred cow.

\section{References}

Akerlof, G.A., Dickens, W.T. and Perry, G.L. (1996), The macroeconomics of low inflation, Brookings Papers on Economic Activity 1, 1-59.

Beck, G.W. and Wieland, V (2007), Money in monetary policy design: A formal characterization of ECB-style cross-checking, Journal of the European Economic Association 5, 524-533.

Begg, D., De Grauwe, P., Giavazzi, F., Uhlig, H. and Wyplosz, C. (1998), The ECB: Safe at any speed?, Monitoring the European Central Bank 1, CEPR.

Bénétrix, A. and Lane, P. (2009), Fiscal shocks and the real exchange rate, IIIS Discussion Paper 286, Trinity College Dublin.

Bernanke, B.S. (2010), Federal Reserve's exit strategy, Testimony before the committee on financial services, U.S. House of Representatives, Washington, D.C.

Blanchard, O.J., Dell'Ariccia, G. and Mauro, P (2010), Rethinking macroeconomic policy, IMF Staff Position Note.

Brunnermeier, M., Crocket, A., Goodhart, C., Persaud, A. and Shin, H. (2009), The fundamental principles of financial regulation, Geneva Reports on the World Economy 11, ICMB and CEPR.

\footnotetext{
${ }^{8}$ An earlier literature (Akerlof et al. 1996; Wyplosz 2001) has also argued that relative price adjustments are difficult at very low inflation rates.
} 
Buiter, W.H. and Panigirtzoglou, N. (2003), Overcoming the zero bound on nominal interest rates with negative interest on currency: Gesell's solution, Economic Journal 113, 723-746.

Canzoneri, M., Cumby, R. and Diba, B. (2001), Is the price level determined by the needs of fiscal solvency?, American Economic Review 91, 1221-38.

Cecchetti, S., Genberg,H., Lipsky, J. and Wadhwani, S. (2000), Asset prices and central bank policy, Geneva Reports on the Word Economy 2, ICMB and CEPR.

Curdia, V. and Woodford, M. (2009), Credit frictions and optimal monetary policy (http://www.columbia.edu/ mw2230/credit_0709.pdf).

Cukierman, A., Webb, S. and Neyapti, B. (1992), Measuring the independence of central banks and its effect on policy outcomes, World Bank Economic Review 6, 353-398.

Eichengreen, B. (1994), International Monetary Arrangements for the $21^{\text {st }}$ Century, The Brookings Institution, Washington, D.C.

Eichengreen, B., Rose, A. and Wyplosz, C. (1996), Contagious currency crises, Scandinavian Journal of Economics 98, 463-84.

Fischer, S. (2001), Exchange rate regimes: Is the bipolar view correct?, Journal of Economic Perspectives 15, 3-24.

Gerlach, S., Giovannini, A., Tille, C. and Viñals, J. (2009), Are the golden years of central banking over? The crisis and the challenges, Geneva Reports on the World Economy 10, ICMB and CEPR.

Ghosh, A., Gulde, A.M. and Wolf, H.J. (2000), Currency boards: More than a quick fix?, Economic Policy 31, 269-336.

Grilli, V., Masciandaro, D. and Tabellini, G. (1991), Political and monetary institutions and public financial policies in the industrial countries, Economic Policy 13, 341-92.

IMF (2009), The state of public finances cross-country fiscal monitor, IMF Staff Position Note, November.

Issing, O. (2001), Monetary theory as a basis for monetary policy: reflections of a central banker, in A. Leijonhufvud (ed.), Monetary Theory and Policy Experience, Palgrave, New York.

Ito, T. (2009), Zero interest rate policies and quantitative easing, in M. Dewatripont, X. Freixas and R. Portes (eds.), Macroeconomic Stability and Financial Regulation: Key Issues for the G20, CEPR, London.

Kaminsky, G.L. and Reinhart, G.M. (2000), On crises, contagion, and confusion, Journal of International Economics 51, 145-168.

Kiyotaki, N. and Moore, J. (1997), Credit cycles, Journal of Political Economy 105, 211-48.

Krugman, P. (1998), It’s baaack! Japan’s slump and the return of the liquidity trap, Brookings Papers on Economic Activity 2, 137-187.

Laubach, T. (2009), New evidence on the interest rate effects of budget deficits and debt, Journal of the European Economic Association 7, 858-885.

Leijonhufvud, A. (2009), Macroeconomics and the crisis: A personal appraisal, Policy Insight 41, CEPR.

Orphanides, A. and Williams, J.C. (2007), Inflation targeting under imperfect knowledge, in F. Mishkin and K. Schmidt-Hebbel (eds.) Monetary Policy under Inflation Targeting, Central Bank of Chile, Santiago. 
Reinhart, C.M. and Rogoff, K.S. (2008), Is the 2007 U.S. sub-prime financial crisis so different?, An international historical comparison, NBER Working Paper 13761.

Rogoff, K. (1996), The purchasing power parity puzzle, Journal of Economic Literature 34, 647-668.

Rother, P. (2004), Fiscal policy and inflation volatility, ECB Working Paper 317.

Sargent, T. and Wallace, N. (1981), Some unpleasant monetary arithmetic, Federal Reserve Bank of Minneapolis Quarterly Review 5, 1-17.

Svensson, L.E.O. (1999), How Should monetary policy be conducted in an era of price stability?, in New Challenges for Monetary Policy, Federal Reserve Bank of Kansas City, Kansas.

Svensson, L.E.O. (2003), Escaping from a liquidity trap and deflation: The foolproof way and others, Journal of Economic Perspectives 17, 145-166.

Svensson, L.E.O. (2010), Inflation targeting after the financial crisis (http://people.su.se/ leosven/papers/100212e.pdf).

Woodford, M. (2008), How important is money in the conduct of monetary policy?, Journal of Money, Credit and Banking 40, 1561-1598.

Wyplosz, C. (2001), Do we know how low should inflation be?, in A. Garcia Herrero, V. Gaspar, L. Hoodguin, J. Morgan and B. Winkler (eds.), Why Price Stability?, European Central Bank, Brussels.

Wyplosz, C. (2010), Picking up the broken pieces when the European debt crisis is over, unpublished manuscript, Graduate Institute, Geneva. 


\section{Appendix: Formula used in Figure 1}

Using the notations from Footnote 2, the budget constraint is:

$b_{t+1}-b_{t}=(r-g) b_{t}-s_{t}$.

If we start year $t=0$ with debt $b_{0}$ and then the crisis raises the debt to $b_{0}+\Delta$, then the constraint for that year is rewritten as:

$b_{1}=[1+(r-g)]\left(b_{0}+\Delta\right)-s_{0}$.

Assuming that the budget balance is set constant so that $s_{t}=s$ for all $t$ until $t$ $=n$, cumulating the budget constraint gives:

$b_{n}=[1+(r-g)]^{n}\left(b_{0}+\Delta\right)-\frac{[1+(r-g)]^{n}-1}{r-g} s$.

Requiring that the debt returns in year $t=n$ to initial level $b_{0}$, so that $b_{n}=b_{0}$, implies that the constant budget balance $s$ is:

$s=(r-g) b_{0}+(r-g) \frac{[1+(r-g)]^{n}}{[1+(r-g)]^{n}-1} \Delta$.

This is the formula used to draw Figure 1, with $r-g=2$ percent and $\Delta=$ 30percent, for $n$ set at 10 and 25 years. 


\title{
The Swedish fiscal policy framework*
}

\author{
Robert Boije, Albin Kainelainen and Jonas Norlin **
}

\section{Summary}

The unfavourable development of public finances in many European Union countries during the current economic crisis has renewed the discussion on the need to strengthen the Stability and Growth Pact (SGP). Besides suggestions on how the pact itself can be strengthened, the importance of national fiscal policy frameworks has been emphasized. The Swedish experience is interesting in this context. As one of few EU countries during the present crisis, Sweden has been able to combine significant fiscal stimuli with limited deficits in the public finances. Deficit and debt levels have also stayed below the levels set by the SGP. It was the ability to maintain surpluses during the good pre-crisis years that made this possible. For this, the existence of a well-defined national fiscal policy framework, combined with a strong political commitment, has been essential. The fiscal policy framework consists of a surplus target for general government, an expenditure ceiling for central government combined with a stringent top-down budget process, a budget-balance requirement on local governments and a Fiscal Policy

Keywords: Budgeting; Balanced budget; Surplus JEL Classification Numbers: H60, H61, H62

${ }^{*}$ The views expressed herein are those of the authors and should not be attributed to the Swedish Ministry of Finance.

${ }^{* *}$ Swedish Ministry of Finance. 
Council responsible for external monitoring. The new Swedish fiscal policy framework has strengthened confidence in the public finances' long-term sustainability, which in turn has contributed to lower risk premia and a more effective stabilization policy. The Swedish experiences support the view thatthe SGP's fiscal rules need to be accompanied by effective national fiscal policy frameworks, and also indicate that such frameworks are a prerequisite for the effectiveness of stabilization policy during severe economic downturns. 
The current economic crisis has led to a rapid deterioration of public finances in most advanced economies. In countries where public debt or fiscal deficits were large before the crisis began, deficits have reached double-digit levels. The large deficits in many countries are problematic since they lead to rapidly rising levels of debt. Between 2008 and 2011, average debt in the EU countries is forecast to increase from around 60 to around 85 per cent of GDP (European Commission, 2010). In addition to the difficult short-term position, in many countries the public finances face substantial long-term challenges from demographic developments. This is worrying given that recent research conducted by Reinhart and Rogoff (2010) has found a strong link between very high levels of debt (above 90 per cent of GDP) and lower economic growth.

The unfavourable development of public finances in many EU countries has renewed the discussion on the need to strengthen the Stability and Growth Pact (SGP). Besides suggestions on how the Pact itself can be strengthened, the importance of national fiscal policy frameworks, as a complement to the Pact, has been emphasized. The fact that the SGP failed fully to promote sound public finances in many European Union countries prior to the crisis can, largely, be attributed to either the non-existence of complementary national fiscal policy frameworks or to the lack of political commitments adhering to such frameworks.

Even though the financial crisis affected Sweden similarly to other countries in terms of loss of GDP, the effect on the public finances has, largely, been less severe. Deficits have been modest, even though Sweden has pursued among the most active contra-cyclical policies during the crisis. This combination was made possible by the large pre-crisis net lending surpluses. Each year since 2000, Sweden has abided by the numerical rules in the SGP and is one of the few EU member countries that have managed to also abide by the rules during the current crisis. The financial markets also seem to have confidence in the sustainability of the Swedish public finances; the interest spread to Germany is close to zero, unlike the case for many other EU countries. This has been important for the effectiveness of the stabilization policy measures taken to combat the crisis.

The relatively favourable development of Sweden's public finances can probably, to a large extent, be attributed to the introduction in 1997-2000 of a well-defined national fiscal policy framework, consisting of a surplus target for general government, an expenditure ceiling for central government 
(combined with a stringent top-down budget process), and a budget-balance requirement on local governments. It also reflects a strong political commitment to adhere to this framework. Since 2007, a Fiscal Policy Council has played a central role in the external monitoring of this framework (Calmfors 2010).

The purpose of this paper is to contribute to the debate on the significance of national fiscal policy frameworks by describing the Swedish framework, as well as its background and experience thus far. The article is organized as follows. Section 1 describes the Swedish fiscal policy framework and its background. In section 2, we briefly evaluate the framework, and in section 3, we give an account of the domestic discussion regarding the remaining weaknesses. Section 4 concludes.

\section{The Swedish fiscal policy framework}

\subsection{Background}

One main driving force behind Sweden's introduction of a fiscal policy framework was the economic crisis in 1992-94, which has been described as worse than the global meltdown in the inter-war period. ${ }^{1}$ Some figures illustrate the abrupt economic downturn: between 1991 and 1993, unemployment rose from 3 to 10 per cent of the labour force and GDP growth was negative. From 1990 to 1993, general government net lending deteriorated from plus 3 to minus 11 per cent of GDP (see Figure 1).

In response to the crisis, Sweden's monetary and fiscal policy frameworks were thoroughly reformed. In the autumn of 1992, speculation against the "krona", encouraged by an earlier series of devaluations, forced the Swedish Central Bank (the Riksbank) to abandon the fixed exchange rate regime. Responsibility for monetary policy, with price stability as its objective, was ultimately transferred to the Riksbank.

\footnotetext{
${ }^{1}$ Another driving force behind Sweden's introduction of a fiscal policy framework was membership of the European Union.
} 


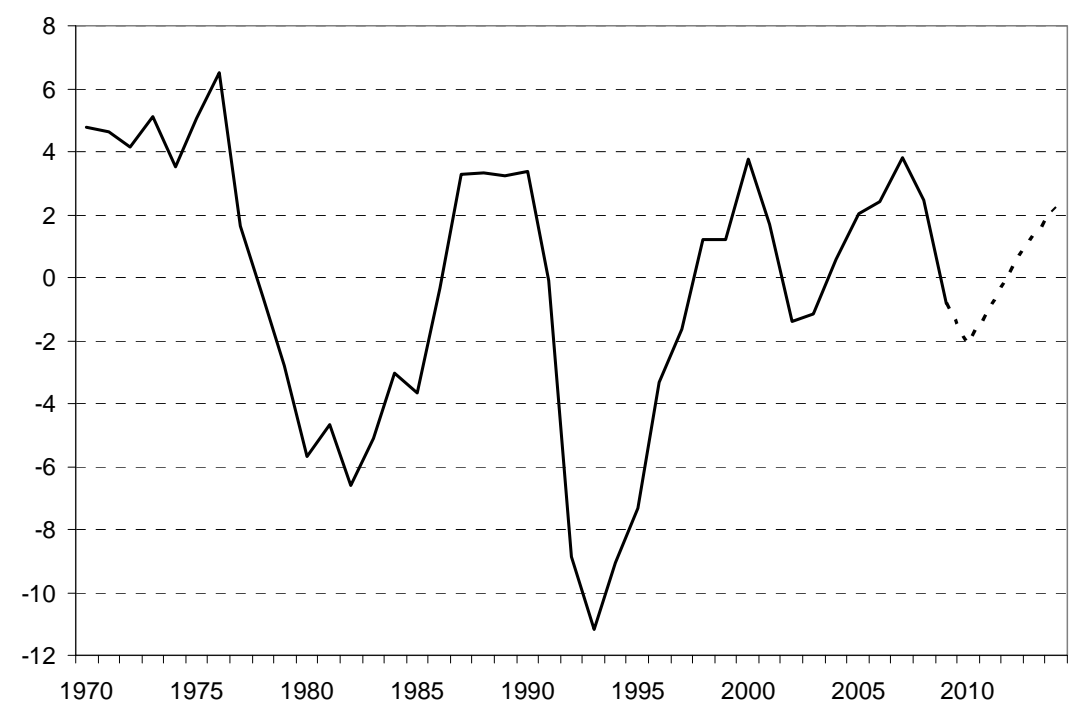

Figure 1: Net lending in Sweden 1970-2014.Per cent of GDP.

Source: Ministry of Finance (2010b) and Statistics Sweden.

Fiscal policy initially aimed at consolidating the public finances. A massive consolidation programme (7.5 per cent of GDP) was successfully implemented stepwise between 1995 and 1998, and was followed by the introduction of the new fiscal policy framework. The new Swedish fiscal policy framework was, thus, to a large extent introduced after the consolidation programme had been completed. While the fiscal policy framework is mainly intended to work as an anchor for future fiscal policy, at its introduction it was also a method for locking-in the fiscal adjustments that the consolidation programme had achieved. As pointed out by the IMF (2009), for example, fiscal rules are more likely to be accepted when countries have already made some progress towards fiscal consolidation. ${ }^{2}$

\footnotetext{
${ }^{2}$ The IMF finds that countries which managed to reduce their debt ratio by more than 2 percentage points (in the three years preceding the introduction of the fiscal rules) were twice as likely to adopt rules as other countries.
} 


\subsection{The surplus target}

The surplus target, introduced in 1997 with full effect from 2000, states that the surplus in net lending shall be 1 per cent of GDP over a business cycle. ${ }^{3}$ Setting a target that is to be met over a business cycle is intended to prevent a pro-cyclical fiscal policy. With an annual surplus as the target, fiscal policy would need to be contractive in a recession, and vice versa; fiscal policy would then be pro-cyclical and not contribute to stabilization of resource utilization.

Over the years, various arguments have been used to motivate the surplus target and the weights attached to each argument have changed. Debt reduction was highlighted in the early stages, followed later by demographic issues. In the 2010 Spring Budget Bill the government clarified that the target should contribute to:

1. Long-term sustainable public finances so that citizens, business and financial markets maintain confidence in fiscal policy.

2. That a sufficient buffer is in place to meet major economic declines and enable an expansionary fiscal policy without causing substantial and sustained deficits in the public finances.

3. Intergenerational equality. In Sweden, as in many other countries, the older segment of the population will increase sharply over the coming decades. During demographically favourable years, relatively high saving translates into markedly reduced national debt. Such saving therefore means that larger generation groups can contribute to the financing of their future medical and care services, while also adding to fairness between generations.

4. Economic efficiency. By enhancing conditions that make it unnecessary to raise the tax ratio (as a consequence of demographic development), a surplus target contributes to economic efficiency.

The government has emphasized that maintaining the long-term sustainability of public finances is a necessary condition for achieving the other motives for the surplus target. If public finances are not sustainable, the finan-

\footnotetext{
${ }^{3}$ The target was originally 2 per cent of GDP. After a decision by Eurostat, that part of the oldage pension system savings should be accounted as private savings, the target was technically adjusted to 1 per cent from 2007.
} 
cial markets and households lose confidence in the government's ability to meet its commitments. The focus of politics then has to be shifted from promoting higher growth, employment and welfare to reducing debt. This is evident not least from what happened in Sweden during and after the crisis in the early 1990s.

International experience from the current financial crisis shows that there are good reasons to ensure that a buffer exists for coping with severe economic downturns and avoiding an unsustainable increase in debt. Having room for fiscal manoeuvring in such situations enables a strong fiscal policy. If financial markets and households lack confidence in the sustainability of public finances, fiscal stabilization measures will be less effective or even counterproductive. Against this background, the Swedish Government has declared that it attaches great importance to the stabilization policy argument provided that long-term fiscal sustainability is maintained. Support for this comes from Leeper (2009), who stresses the importance of maintaining a risk-free fiscal policy, i.e. a policy that ensures that the probability of the economy approaching its fiscal limit is negligible, so that investors do not demand a risk premium for holding the government's bonds. The financial markets' reactions differ between different types of economy. The ability to maintain surpluses in good years is likely to be particularly important for small open economies with their own currency and with large automatic stabilizers, like the Swedish. Haugh et al. (2009) present empirical evidence indicating that in times of global financial stress, such economies often are more vulnerable in terms of risk premia.

Regarding the surplus target's contribution to intergenerational equality and economic efficiency, the Swedish Government has recently announced that the target should be used only to manage the increase in the proportion of elderly which results from temporary changes, i.e. it should not be used to manage the continual increase in average life expectancy. ${ }^{4}$ It has also emphasized that the surplus target should not be used to pre-fund any future demand for a higher quality of publically provided services.

It is only natural that the relative weights attached to the various motives change over time. In the 2010 Spring Budget Bill, the government therefore also declared that the motives behind the surplus target and its level should be reassessed at regular intervals. However, to prevent the net lending target

\footnotetext{
${ }^{4}$ This is in line with the view in Andersen (2008).
} 
from losing its role as a medium-term anchor for fiscal policy, it is important that such overhauls are not done too frequently. Furthermore, it is of great importance that the overhauls are not used to justify deviations from targets.

When Sweden introduced the surplus target, there was very little published analysis concerning the level of such a target. The level was chosen on the grounds that net debt should be eliminated in the coming 10-15 years. When this was achieved already in 2001, the motivation for the level remained unchanged. Recently, however, a government report presented such an analysis (Ministry of Finance, 2010a). Given the motives specified by the government, the report concluded that there are no strong reasons for changing the current level of 1 per cent. At present, moreover, there are no major conflicts between the motives for the target.

\subsection{The expenditure ceiling}

The Swedish expenditure ceiling, introduced in 1997, covers the primary expenditures of the central government together with expenditure of the oldage pension system. The ceiling is set by Parliament on the basis of a government proposal in the Budget Bill. The ceiling was used by the government on a voluntary basis up to 2010. From 2010, the government is required by law to propose an expenditure ceiling for year $t+3$ in the Budget Bill for year $t+1$ (presented in the autumn of year $t$ ). For example, in the Budget Bill for 2010 presented in the autumn of 2009, the government proposed a ceiling for 2012. The Swedish Government is obliged by law to take necessary measures to secure that actual expenditures do not exceed the ceiling. The practice is that once a ceiling has been set, it should not be changed unless technically motivated. ${ }^{5}$ This secures a medium-term planning horizon. It is possible to change set ceilings for non-technical reasons, but this has only occurred twice and on both occasions the ceiling was lowered. ${ }^{6}$

Normally the ceiling is set to include a buffer that can be used for expenditure arising from unforeseen cyclical factors. This buffer is called the

\footnotetext{
${ }^{5}$ Adjustments shall be done for "technical reasons", for instance if responsibility for an item of expenditure is transferred from central to local government without affecting the level of expenditure in the general public sector.

${ }^{6}$ One may argue that the possibility of changing the set ceilings is a weakness of the framework. However, a new government must be able to choose a ceiling that is consistent with its priorities.
} 
"budgeting margin". The government's practice has been for the budgeting margin to be at least 3 per cent of forecast expenditure for year $t+3$, at least 2 per cent for year $t+2$, at least 1.5 per cent for year $t+1$ and at least 1 per cent for the current budget year. The ceilings are set in nominal terms (thus they are not adjusted for inflation).

The Swedish budget process is characterized by a top-down perspective (see Section 1.5). The expenditure ceiling is the overarching restriction on the budget process in terms of total expenditure. Throughout the process, from the setting of the ceiling to the completion of the budget year, it is mandatory to prioritise between different areas of expenditure. In addition, the ceiling's medium-term perspective provides conditions whereby temporary increases in revenue (due, for example, to cyclical factors) are not used to finance permanently higher expenditure. This also limits the risk of pursuing a destabilizing (pro-cyclical) fiscal policy on the expenditure side.

Consequently, the expenditure ceiling constitutes an important policy commitment that promotes budget discipline and strengthens economic policy's credibility. It improves the probability of achieving the surplus target and promotes long-term sustainable finances. The level of the ceilings should also promote a desirable long-term development of central government expenditure. Together with the surplus target, the ceilings are central for controlling the overall level of taxation and help to avoid a situation in which poor expenditure control necessitates gradually higher taxes.

\subsection{The budget-balance requirement on local governments}

The local government sector in Sweden is responsible for roughly 45 per cent of the general public sector's expenditures. To strengthen the budgetary process at local level, local governments are, from 2000, required by law to plan for revenues that cover or exceed expenditures. A local government that reports a deficit ex post has to correct it within three years. The budgetbalance requirement applies to the financial result net of extraordinary items. It accordingly follows a different accounting practice from that of the surplus target, which is defined in accordance with the standard for national accounts (ESA 95).

The local government balanced-budget requirement is a minimum requirement. The Swedish Local Government Act stipulates that municipalities and county councils shall also comply with principles of good financial 
management. Thus, their budgets should also take into account future costs such as major pension undertakings. However, there is no explicit sanction mechanism in the event of non-compliance with this balance requirement (apart from the response from the electorate). Despite the lack of sanctions, compliance has thus far been good (see Section 2.3).

\subsection{A stringent budget process}

The top-down perspective in the Swedish budget process entails a procedure whereby different expenditure proposals are set against each other, and any overall increase in spending has to be accommodated in the expenditure ceiling's predetermined limit on total expenditure.

Parliament's processing and resolution of the budget follows a distinct top-down perspective. The expenditures are presented under 27 headings, which reflect areas of expenditure. As a first step, Parliament decides on the spending plans for each of these areas and develops an estimate of the state budget revenues. In a second step, the various committees deal with appropriations for each expenditure item. Since the 27 expenditure areas have already been decided in the first step, they constitute a binding constraint in the second step. This effectively means that, at this stage, an increased appropriation in one category has to be combined with a proposal to reduce another appropriation in the same expenditure area.

One important feature of this budget process is transparency. The general rule is that all items are reported gross. In other words, transactions cannot be hidden by reporting only net flows. Another important feature is "the completeness principle", meaning that every item affecting the public borrowing requirement will be included in the state budget. This results in a clear statement of government commitments and a better understanding of the state budget. A third important feature is that the Minister of Finance has the central role in managing the budget process.

\subsection{External monitoring of compliance}

Monitoring compliance by external observers is important for the Swedish budget policy framework. In 2007, the Swedish Government therefore established a Fiscal Policy Council with a number of tasks, among them is assess- 
ing the extent to which government fiscal policy objectives are being achieved (Calmfors, 2010).

The Council is formally an agency under the government, which appoints the eight members for a three-year period. The appointments are based on proposals from the Council and these proposals are made public, meaning that the government's reputation is liable to suffer if it does not follow the proposals.

A number of other agencies also contribute to the external monitoring; for example, the Swedish National Financial Management Authority, the National Institute of Economic Research and the Swedish Audit Office.

\subsection{The legal status of the framework}

To date, the Swedish fiscal policy framework has been regulated by law to only a small extent. Rules enshrined in legislation are likely to be more difficult to reverse or abandon than are rules not supported by law. Acting on government proposals, Parliament has therefore made the use of expenditure ceilings and a medium term net lending target compulsory, by law, from January 1, 2010 and August 1 2010, respectively. The level of the targets should not, however, be subject to legislation. The law concerning expenditure ceilings and the surplus target can be overruled by a simple majority, but changing this law may involve loss of reputation and is therefore likely to be politically costly. Regarding the status of the Fiscal Policy Council, the opposition parties were against its introduction in 2007. However, the opposition's recent joint budget statement states nothing about the future of the Fiscal Policy Council.

\section{An evaluation of the Swedish fiscal policy framework since 2000}

\subsection{The surplus target}

When the surplus target was introduced, there were no clear principles for monitoring compliance. Such principles have been developed gradually (and also changed) over time. The required surplus is to be achieved on average over the business cycle, but the length of the business cycle is not specified 
either ex ante or ex post. In recent years, three indicators have been used to assess compliance: (i) average net lending since 2000 (the year the surplus target was introduced) ${ }^{7}$; (ii) a centred, seven-year moving average of net lending, which captures the current budget year, the three preceding years, and the three "forecast years" following the current budget year; and (iii) the structural budget balance. ${ }^{8}$

The first indicator has been used for retrospective evaluation. The "seven year moving average indicator" has been used as a forward-looking indicator "with memory". Although the retrospective indicator does cover many years, there is no guarantee that the average GDP gap in the relevant period is zero. The probability of the average GDP gap being non-zero is even higher for the seven-year moving average indicator. In the evaluation of these indicators the government therefore takes into account the average GDP gap in the relevant periods. If the retrospective indicator and the seven-year moving average indicator are both close to 1 over the relevant periods at the same time as the GDP gap on average is close to zero, those indicators indicate compliance. The structural budget balance is used to measure compliance in individual years. For compliance, the structural budget balance should be close to 1 per cent of GDP each year, unless discretionary stabilization policy measures are warranted. For example, in a severe economic slowdown, the structural budget balance is allowed to (and should) be smaller than 1 per cent of GDP.

The practice has been that, given the values of the three indicators, the government makes an overall assessment of compliance, in which allowance is also made for the uncertainty of the assessment and the risk scenario (among other things, the risk of an asymmetric business cycle). Although the indicators are presented as percentages of GDP, normally, the overall assessment is qualitative. The government only states whether fiscal policy seems to be in line with the surplus target, whether there is scope for unfunded reforms, or whether consolidation measures are called for. Thus, in the event of an estimated deviation from the surplus target, the deviation is normally not specified exactly in monetary terms.

\footnotetext{
${ }^{7}$ From the 2010 Spring Budget Bill and onward the government has stated that this indicator will be replaced by a backward-looking 10 year moving average of net lending.

${ }^{8}$ Structural budget balance is actual net lending adjusted for the GDP gap times an elasticity of 0.55, plus corrections for one-off effects and extraordinary tax income from capital gains.
} 
Table 1: Surplus target indicators Per cent of GDP and potential GDP

\begin{tabular}{|c|c|c|c|c|c|c|c|c|c|c|}
\hline & 00 & 01 & 02 & 03 & 04 & 05 & 06 & 07 & 08 & 09 \\
\hline Net lending & 3.7 & 1.7 & -1.4 & -1.2 & 0.6 & 2.0 & 2.4 & 3.8 & 2.5 & -0.8 \\
\hline \multirow{2}{*}{$\begin{array}{l}\text { Average since } 2000 \\
\text { cyclically adjusted }^{\text {a) }}\end{array}$} & 3.7 & 2.7 & 1.3 & 0.7 & 0.7 & 0.9 & 1.1 & 1.5 & 1.6 & 1.3 \\
\hline & 2.5 & 2.3 & 1.4 & 1.0 & 0.9 & 1.1 & 1.1 & 1.2 & 1.4 & 1.4 \\
\hline \multirow{2}{*}{$\begin{array}{l}\text { Seven-year indicator } \\
\text { cyclically adjusted }^{\text {a) }}\end{array}$} & & & & 0.9 & 1.0 & 1.1 & 1.2 & & & \\
\hline & & & & 0.9 & 0.9 & 0.9 & 1.3 & & & \\
\hline Structural BB & 1.1 & 2.1 & -0.3 & 0.1 & 0.4 & 1.1 & 0.6 & 1.6 & 2.3 & 2.2 \\
\hline GDP gap & 2.2 & -0.9 & -1.5 & -1.9 & -0.1 & 0.4 & 2.4 & 2.6 & 0.0 & -5.3 \\
\hline Average since 2000 & 2.2 & 0.7 & -0.1 & -0.5 & -0.4 & -0.3 & 0.1 & 0.4 & 0.4 & -0.2 \\
\hline Seven-year average & & & & 0.1 & 0.2 & 0.3 & -0.3 & & & \\
\hline
\end{tabular}

Source: Ministry of Finance and Statistics Sweden.

Note: a) The indicator has been cyclically adjusted by the average GDP gap for the relevant time period times a budget elasticity of 0.55 .

Table 1 shows the performance of the surplus target, evaluated ex post. Average net lending since 2000 (as well as the cyclically adjusted figure) has from 2002 been close to 1 per cent of GDP. The seven-year moving average indicator (as well as the cyclically adjusted figure) has also been close to 1 per cent of GDP in each year. Ex post the structural budget balance has varied substantially over the years, not always in a way that seems to be motivated by the surplus target and the GDP gap. This simple exercise does not prove that the surplus target has been a strictly binding restriction ex ante but it does show that the surplus target, ex post, has largely been respected on average over time. Table 1 also shows that the government has been able to maintain substantial surpluses in the good years before the financial crisis.

\subsection{The expenditure ceiling}

Table 2 shows that the expenditure ceiling has been respected in every year since 2000. It is also clear from the table that in some years the budgeting margin has been very small. In the period 2000-05 the (ex post) budgeting margin never exceeded 1 per cent of expenditures. During the latest four years the budgeting margin, on average, has exceeded 2 per cent of expenditures. 
Table 2: Expenditure ceiling and budgeting margin. Billions of SEK

\begin{tabular}{lrrrrrrrrrr}
\hline & $\mathbf{0 0}$ & $\mathbf{0 1}$ & $\mathbf{0 2}$ & $\mathbf{0 3}$ & $\mathbf{0 4}$ & $\mathbf{0 5}$ & $\mathbf{0 6}$ & $\mathbf{0 7}$ & $\mathbf{0 8}$ & $\mathbf{0 9}$ \\
\hline $\begin{array}{l}\text { Expenditure } \\
\text { ceiling }\end{array}$ & 765 & 791 & 812 & 822 & 858 & 870 & 907 & 938 & 957 & 989 \\
$\begin{array}{l}\text { Budgeting } \\
\text { margin }\end{array}$ & 5.0 & 4.7 & 0.4 & 2.9 & 2.4 & 5.7 & 11.8 & 27.9 & 13.6 & 24.4 \\
$\begin{array}{l}\text { Per cent of expendi- } \\
\text { ture below the ceiling }\end{array}$ & 0.7 & 0.6 & 0.0 & 0.4 & 0.3 & 0.7 & 1.3 & 3.1 & 1.4 & 2.5 \\
\hline
\end{tabular}

Source: Ministry of Finance.

\subsection{The balanced-budget requirement on local governments}

Table 3 shows that, except for the years 2002-03, when capacity utilization was low, the local government sector as a whole has shown a surplus. The general perception is that the balanced-budget requirement has contributed to a significant improvement in local government finances.

Table 3: Result for the local government sector. Billions of SEK

\begin{tabular}{lrrrrrrrrrr}
\hline & $\mathbf{0 0}$ & $\mathbf{0 1}$ & $\mathbf{0 2}$ & $\mathbf{0 3}$ & $\mathbf{0 4}$ & $\mathbf{0 5}$ & $\mathbf{0 6}$ & $\mathbf{0 7}$ & $\mathbf{0 8}$ & $\mathbf{0 9}$ \\
\hline Municipalities & 5.2 & 4.7 & 0.6 & 1.7 & 2.4 & 9.0 & 13.3 & 10.1 & 7.0 & 11.6 \\
County councils & -3.8 & -3.4 & -7.6 & -2.5 & -0.2 & 4.2 & 1.8 & 4.0 & 0.9 & 2.8 \\
Total & 1.4 & 1.3 & -7.1 & -0.8 & 2.2 & 13.3 & 15.2 & 14.1 & 7.9 & 14.4
\end{tabular}

Source: Ministry of Finance.

\subsection{Political commitment important for compliance}

As shown above, there has been no major deviation from the fiscal policy framework in Sweden since it was introduced. This has established a dependence on a "good" path so that future deviations from the framework are likely to be politically costly. The economic crisis in the early 1990s and the subsequent efforts for consolidation established a strong sense, among policy makers as well as voters, of the necessity for avoiding large deficits. The fiscal policy framework was established as a consequence of this insight. Today's strong political support for the fiscal policy framework (only the Left Party opposes it), is largely traceable to the experience of the crisis in the early 1990s. One interpretation of this is that a fiscal crisis necessitating consolidation measures generally must occur to establish a strong sense among policy makers of the importance of fiscal policy frameworks in the political decision process. 


\section{Weaknesses of the Swedish fiscal policy framework and room for improvements}

We consider that the Swedish fiscal policy framework has improved fiscal performance in Sweden (although we do not have formal proof of this from, for example, econometric tests). The Swedish case indicates that national rules, backed by a strong political commitment, surveillance by several national institutions and transparent, comprehensive and stringent budget procedures, do improve fiscal performance. Although the general testimonial is good, certain aspects of the Swedish fiscal policy framework have been criticized. In particular, the Swedish Audit Office (2008) and the Fiscal Policy Council (2009) have identified what they perceive as weaknesses of the Swedish fiscal policy framework. Below we briefly discuss these issues separately for the surplus target, the expenditure ceiling and the balancedbudget requirement on local governments.

\subsection{The surplus target}

The Swedish Audit Office (2008) and the Fiscal Policy Council (2009) have criticized the formulation of the surplus target as being too imprecise for stringent monitoring. They have argued that the current lack of definition for the business cycle may give the Swedish Government too much freedom, and that consequently, the surplus target may not be a binding constraint. The government's use of several indicators to follow up the target as well as the absence of a specified corrective arm to deal with slippages from the target, have also been criticized.

One could of course consider an evaluation of the surplus target over a well-defined period, and the introduction of a binding corrective arm mechanism in the event of non-compliance. Such a model would do away with the need to use several different indicators to follow up the surplus target. If net lending, on average, is not 1 per cent over this clearly defined period, the conclusion would be that the target has not been met and that corrective measures are required. However, we believe that such an alternative formulation of the target would not be expedient. Obviously a surplus target that has to be met over a clearly specified period, without taking the GDP gap into account, risks leading to a pro-cyclical policy. 
An alternative solution that does take the risk of a pro-cyclical policy into account would be to define the target directly in terms of structural net lending and to correct deviations from the structural net lending target only when "the GDP gap permits this". This method will be used in the new German fiscal policy framework; Switzerland has a similar construction. ${ }^{9}$ However, we have doubts about the method because calculations of the structural budget balance are highly uncertain. Experience from Sweden shows that the measure of the structural budget balance for a given (historic) year can undergo dramatic revisions over time. For example, the measure of this balance for 2001 was adjusted by 3.5 per cent of GDP between the 2001 Spring Budget Bill and the 2008 Budget Bill (in the absence of new policy!). This example shows that a corrective mechanism built on deviations from the target for the structural budget balance is likely to be problematic. However, we still believe that a measure of the structural budget balance could be used as one indicator of compliance, among others.

According to the IMF (2009), formal enforcement procedures should rely on mandating corrective action and/or mechanisms that maximize the reputational cost of not taking action. Germany and Switzerland are examples of countries that use the first approach, while Sweden uses the second. In Sweden, the Fiscal Policy Council, and other institutions, are vital for creating a high reputational cost of deviations. ${ }^{10}$ It is likely that countries with a good public finance track record, where the memory of earlier fiscal crises has contributed to strong political support for the fiscal policy framework, can rely on reputational cost to a greater extent than other countries. It is also likely that this enables a more qualitative approach to the assessment of potential deviations from targets. However, if the memory of earlier fiscal crises fades, and this gives rise to deliberate deviations from fiscal targets, it may be necessary, also in Sweden, to introduce a stronger corrective arm instead of just relying on reputational cost.

\subsection{The expenditure ceiling}

Both the Swedish Audit Office (2008) and the Fiscal Policy Council (2009) have also criticized certain aspects of the expenditure ceiling. A first objec-

\footnotetext{
${ }^{9}$ For an overview of the recent reform of the German fiscal policy framework, see Federal Ministry of Finance (2009).

${ }^{10}$ Debrun et al. (2009) show large effects of fiscal councils on budgetary outcomes.
} 
tion is the lack of clear principles for how the ceiling is set and especially how it corresponds to the surplus target. A second is that on two occasions the period for which the ceiling is set in advance has been shortened. A third objection is that "creative" accounting has been used to avoid exceeding the ceiling; for example, expenditure has either been booked on the income side of the budget in the form of tax deductions (so called tax expenditures) or transferred from one year to another when the first year's margin under the ceiling was becoming too narrow.

Regarding the first objection, there are no clear principles for how the ceiling is set. A government that gives priority to expenditure over tax reductions is likely to choose a principle for determining the ceiling that differs from that of a government that prefers tax reductions. However, both types of government must adhere to the surplus target laid down by Parliament. The current government has chosen to set the ceiling as a slightly diminishing proportion of potential GDP. Once the ceiling has been set, it is of course important that the government closely follows how the scope for new unfunded reforms under the expenditure ceiling corresponds to the room allowed by the surplus target. This is also done in the Budget Bill and the Spring Budget Bill. Given the forecast of tax revenue and expenditure (assuming unchanged policy) the surplus target gives the total room for new unfunded reforms or the need of consolidation measures. If tax revenue happens to grow more slowly than was expected when the expenditure ceiling was set, the budgeting margin may indicate scope for new unfunded reforms while the surplus target does not. The surplus target is then the binding restriction.

Regarding the second objection, the current government has maintained the principle of proposing a new expenditure ceiling on a three-year forwardlooking basis. As noted above, following a proposal from the government, Parliament has also made the three-year perspective mandatory by law.

Regarding the third objection, creative accounting has occurred but on just a very limited scale under both the current and the former government. The operations have also been presented to the Parliament in a transparent way.

\subsection{The balanced-budget requirement on local governments}

Although the balanced-budget requirement has contributed to improved finances in the local public sector, it has been criticized, for example, by the 
Fiscal Policy Council (2009) for contributing to a pro-cyclical policy at the local level. Since the municipalities and county councils are required to plan for balanced budgets each year, there is of course a risk that they will tend to reduce expenditure when tax revenue falls in years with low capacity utilization, and vice versa. The government has acknowledged this problem and recently appointed a committee to propose how it can be handled (subject to the restriction that the proposal shall not weaken the fiscal position of municipalities and county councils). Among potential solutions, the committee will analyze a mandatory "rainy day" fund to which municipalities and county councils would be obliged to contribute in "good" years, and from which they would receive payments in "bad" years.

\section{Concluding remarks}

In this paper we have discussed, with reference to the Swedish experience, how a well-designed fiscal policy framework can help to promote sound public finances. Our conclusion is that the Swedish fiscal policy framework has made a significant contribution to the enhancement of confidence in the long-term sustainability of the public finances, and that it has also enabled an effective stabilization policy during the current crisis. As one of just a few European Union countries during the present economic crisis, Sweden has been able to combine significant fiscal stimuli with limited deficits in the public finances - without increases in risk premia. Deficit and debt levels have also stayed below the levels set by the SGP. This supports the view that national fiscal policy frameworks are likely to improve the performance of the SGP.

However, a well-designed fiscal policy framework on paper is not a sufficient condition for fiscal sustainability and a responsible fiscal policy over the business cycle. Prior to the crisis, several countries that had a fiscal policy framework that ranked high on paper (see European Commission 2009), actually did badly during the financial crisis. For a fiscal policy framework to work properly there must be a strong political belief that such frameworks actually matter as well as a political commitment to respecting them. Such political commitment is likely to be stronger in countries, such as Sweden, with recent experience of fiscal crisis. Seen from this perspective, in many countries today's fiscal crisis is likely to be a loud "wake-up call”. 
We hope that this paper - which has described the Swedish fiscal policy framework, its background, and our mainly positive experiences of it - can serve as an inspiration to countries that are in the process of introducing a fiscal policy framework. At the same time, we of course acknowledge that there is no one-size-fits-all solution as regards the construction of a fiscal policy framework.

\section{References}

Andersen, T. (2008), Fiscal sustainability and demographics - should we save or adjust?, CEPR Discussion Paper 7044.

Calmfors, L. (2010), The Swedish fiscal policy council - experiences and lessons, Paper for Conference on Independent Fiscal Policy Institutions, Budapest, 18-19 March 2010, Swedish Fiscal Policy Council.

Debrun, X., Hauner, D. and Kumar, M.S. (2009), Independent fiscal agencies, Journal of Economic Surveys 23, 44-81.

European Commission (2009), Public finances in EMU 2009, European Economy 5/2009.

European Commission (2010), Spring economic forecast, European Economy 2/2010.

Federal Ministry of Finance (2009), Reforming the constitutional budget rules in Germany, Working paper.

Haugh, D., Ollivaud P. and Turner, D. (2009), What drives sovereign risk premiums? An analysis of recent evidence from the Euro area, Economics Department Working Papers 718, OECD.

IMF (2009), Fiscal rules - anchoring expectations for sustainable public finances, IMF Staff Paper, Washington, D.C.

Leeper, E. (2009), Anchoring fiscal expectations, NBER Working Paper 15269.

Ministry of Finance (2010a), Svenska Finansdepartementet: Översyn av överskottsmålet 2010, Ds 2010:4.

Ministry of Finance (2010b), Svenska Finansdepartementet: Vårpropositionen 2010, Prop. 2009/10:100.

Reinhart, C. and Rogoff, K. (2010), Growth in a time of debt, American Economic Review, forthcoming.

Riksrevisionen (2007), Regeringens uppföljning av överskottsmålet 2007, RiR 2006:27.

Swedish Fiscal Policy Council Report (2008), Svensk finanspolitik - Finansplitiska rådets rapport 2008, Swedish Fiscal Policy Council, Stockholm.

Swedish Fiscal Policy Council Report (2009), Swedish Fiscal Policy 2009, Swedish Fiscal Policy Council, Stockholm. 
Notes 





\section{norden}

Nordic Council of Ministers

Ved Stranden 18

DK-1061 Copenhagen K

www.norden.org 